Andrews University

Digital Commons @ Andrews University

\title{
An Initial Exploration of the Undergraduate English Major Curricula Issued by the 2000-2001 Member Schools of the Council for Christian Colleges and Universities
}

Maralee Sue Crandon

Andrews University

Follow this and additional works at: https://digitalcommons.andrews.edu/dissertations

Part of the Curriculum and Instruction Commons, and the English Language and Literature Commons

\section{Recommended Citation}

Crandon, Maralee Sue, "An Initial Exploration of the Undergraduate English Major Curricula Issued by the 2000-2001 Member Schools of the Council for Christian Colleges and Universities" (2008). Dissertations. 1710.

https://digitalcommons.andrews.edu/dissertations/1710

https://dx.doi.org/10.32597/dissertations/1710

This Dissertation is brought to you for free and open access by the Graduate Research at Digital Commons @ Andrews University. It has been accepted for inclusion in Dissertations by an authorized administrator of Digital Commons@ Andrews University. For more information, please contact repository@andrews.edu. 


\begin{abstract}
AN INITIAL EXPLORATION OF THE UNDERGRADUATE ENGLISH MAJOR CURRICULA ISSUED BY THE 2000-2001 MEMBER SCHOOLS OF THE COUNCIL FOR CHRISTIAN COLLEGES AND UNIVERSITIES
\end{abstract}

by

Maralee Sue Crandon

Chair: Lyndon G. Furst 


\title{
ABSTRACT OF GRADUATE STUDENT RESEARCH
}

Dissertation

\author{
Andrews University \\ School of Education
}

\section{Title: AN INITIAL EXPLORATION OF THE UNDERGRADUATE ENGLISH MAJOR CURRICULA ISSUED BY THE 2000-2001 MEMBER SCHOOLS OF THE COUNCIL FOR CHRISTIAN COLLEGES AND UNIVERSITIES}

Name of researcher: Maralee Sue Crandon

Name and degree of faculty chair: Lyndon G. Furst, Ed.D.

Date completed: December 2007

\section{Problem}

This study made the initial exploration of English major curricula among 101 members of the 2000-2001 Council for Christian Colleges and Universities (CCCU), describing their nature and state and discerning evidence of Christian thought.

\section{Method}

Stewart's (1989) Modified Categories of English Majors and Eisner's (1991) education criticism provided frameworks to categorize all curricula and to describe a purposeful sampling of 20 selected by region, religious, and enrollment.

Results

Types 1.0 Straight Literature and 1.5 Primarily Literature majors represented 78\% 
of the population and $75 \%$ of the sampling; Type 2.0 More Flexible majors represented $18 \%$ of the population and $25 \%$ of the sampling.

The sampling found two structural models: the traditional tripod model (45\%) and the core-and-periphery (55\%). Types 1.0 and 1.5 emphasized American and English/ British literatures, Type 1.0 by genres, and Type 1.5 by surveys; Type 2.0 stressed those literatures, but proliferated writing electives.

Content weaknesses included the (a) lack of goals; (b) slighting of writing, composition, and rhetoric; and (c) imbalance of 300-level courses. Strengths included (a) offering literary criticism, (b) requiring capstone/seminars, and (c) increasing writing programs.

Christian thought appeared in four course categories: (a) biblical content, (b) integration, (c) major authors associated with Christianity, $5^{\text {th }}$ through $19^{\text {th }}$ centuries, and (d) those associated during the $20^{\text {th }}$ century. Milton, Chaucer, and C. S. Lewis dominated.

\section{Conclusions}

The aggregate CCCU English major curriculum appeared to be:

1. Dominated by literature, especially British/English and American literatures

2. Structured in the traditional tripod of literature, composition, and grammar, or in the core-and-periphery model

3. Utilitarian-oriented toward "helping professions," teaching, and graduate studies 
4. Static with minimized composition, writing, rhetoric, linguistics, and nontraditional literatures

5. Accommodating of writing electives

6. Preserving of field-coverage in upper-level literature courses and

7. British-Christian influenced, reflecting Christian ideas through British historical, cultural, white-male perspective(s). 
Andrews University

School of Education

\title{
AN INITIAL EXPLORATION OF THE UNDERGRADUATE ENGLISH MAJOR CURRICULA ISSUED BY THE 2000-2001 MEMBER SCHOOLS OF THE COUNCIL FOR CHRISTIAN COLLEGES AND UNIVERSITIES
}

\author{
A Dissertation \\ Presented in Partial Fulfillment \\ of the Requirements for the Degree \\ Doctor of Philosophy \\ by \\ Maralee Sue Crandon
}

March 2008 
(C) Copyright by Maralee Sue Crandon 2008 All Rights Reserved 


\title{
AN INITIAL EXPLORATION OF THE UNDERGRADUATE ENGLISH MAJOR CURRICULA ISSUED BY THE 2000-2001 COUNCIL FOR CHRISTIAN COLLEGES AND UNIVERSITIES
}

\author{
A dissertation \\ presented in partial fulfillment \\ of the requirements for the degree \\ Doctor of Philosophy
}

by

Maralee Sue Crandon

APPROVAL BY THE COMMITTEE:

Chair: Lyndon G. Furst

Dean, School of Education

James R. Jeffery

Member: Larry D. Burton

Member: Douglas A. Jones

External:

Date approved 


\author{
Dedicated to \\ My Bethel College mentors \\ Professor Bernice Schultz Pettifor \\ and \\ Dean Michael L. Holtgren- \\ and to my aunts \\ Mrs. Ruth E. Bowman \\ and \\ Professor Janet L. Navin
}




\section{TABLE OF CONTENTS}

LIST OF ILLUSTRATIONS $\ldots \ldots \ldots \ldots \ldots \ldots$. . . . . . . . . vii

LIST OF TABLES $\ldots \ldots \ldots \ldots \ldots \ldots \ldots \ldots \ldots$ viii

LIST OF ABBREVIATIONS . . . . . . . . . . . . . . xi

ACKNOWLEDGMENTS $\ldots \ldots \ldots \ldots \ldots \ldots$ xii

Chapter

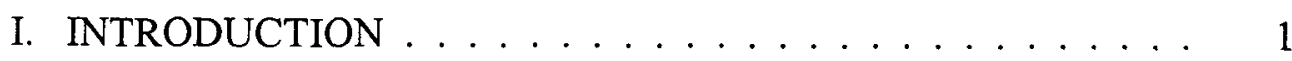

The Problem . . . . . . . . . . . . . . . . . 9

Purpose of the Study . . . . . . . . . . . . . . . . 12

Significance of the Study . . . . . . . . . . . . . . . 13

Research Questions . . . . . . . . . . . . . . . 15

Theoretical Framework for Curricular Analysis . . . . . . . . 16

General Terms . . . . . . . . . . . . . . . . 16

Premises . . . . . . . . . . . . . . . . 18

Qualitative Features . . . . . . . . . . . . . 18

Definitions of Terms . . . . . . . . . . . . . . 21

Delimitations of the Study . . . . . . . . . . . . 2 21

Summary of Chapter $1 \ldots \ldots \ldots . \ldots \ldots 22$

II. REVIEW OF THE LITERATURE . . . . . . . . . . . . . 25

Research on the English Curriculum . . . . . . . . . . . . . 25

Periodic Surveys Signal a Research Wave . . . . . . . . . 26

Qualitative Studies Mark a Transition . . . . . . . . . . 32

Case Studies Rise and Swell . . . . . . . . . . . . . . 36

Peck's Study of Presbyterian College English Programs . . . . . 40

The Contemporary Field of Curriculum and Eisner. . . . . . . . 43

Rationale for Using Eisner's Education Criticism . . . . . . . 47

III. METHODOLOGY . . . . . . . . . . . . . . . . . 52

The Population of This Study . . . . . . . . . . . . . . . . 53

Data Collection . . . . . . . . . . . . . . . 54

The Research Questions . . . . . . . . . . . . . . . . . 57 
Main Framework for the Data Analysis . . . . . . . . . . . 60

Applying the Main Framework: Description . . . . . . . 64

Applying the Main Framework: Interpretation

and Evaluation $\ldots \ldots \ldots$

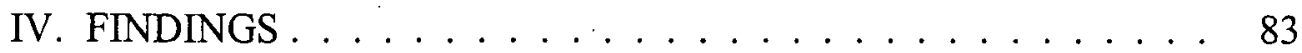

Nature and State of the CCCU English Curriculum . . . . . . 88

English Major Categories by Content Types . . . . . . . . . 88

Claims Among English Curricula . . . . . . . . . . . . . . . 96

Goals, Aims, and Objectives . . . . . . . . . . . . . . . . . . . . . 99

Organization of the Curricula. . . . . . . . . . . . . . 105

Content of the Curricula . . . . . . . . . . . . . . 111

Patterns Evident Among the Curricula . . . . . . . . . . 127

Weaknesses and Strengths . . . . . . . . . . . . . . . . 139

Weaknesses . . . . . . . . . . . . . . . . . 140

Strengths . . . . . . . . . . . . . 153

Evidence of Christian Thought . . . . . . . . . 170

Biblical Content . . . . . . . . . . . . . . . 172

Integrated Content . . . . . . . . . . . . . . . 173

Major Authors Associated With Christianity

Through the 19th Century . . . . . . . . . . . . 178

Major Authors Associated With Christianity

Throughout the 20th Century . . . . . . . . . . . 179

Summary of the Nature and State of the English Curriculum . . . 196

V. SUMMARY, CONCLUSIONS, AND RECOMMENDATIONS. . . 201

Context: English and Its Undergraduate Curriculum . . . . . . 201

Context: Contemporary Curriculum Thought and Eisner . . . . 206

The Research Questions . . . . . . . . . . . . . . . . . . . . 209

The Population . . . . . . . . . . . . . . . . 210

The Data Collection . . . . . . . . . . . . . . . . 211

The Frameworks: Stewart's and Eisner's . . . . . . . . . 211

Tools Designed to Apply Eisner's Framework . . . . . . . 213

Tools Appropriated to Apply Eisner's Framework . . . . . 215

Findings for Research Question 1: Nature and State . . . . . . 216

Findings for Research Question 2: Evidence of Christian Thought 248

Conclusions . . . . . . . . . . . . . . . 252

Recommendations for Further Study . . . . . . . . . . . . . 254

Final Remarks . . . . . . . . . . . . . . . . . . . 255 
Appendix

A. MEMBERS OF THE COUNCIL FOR CHRISTIAN COLLEGES AND UNIVERSITIES, THEIR LOCATIONS, RELIGIOUS AFFILIATIONS, AND UNDERGRADUATE ENROLLMENTS . . . . . . . . . . . 256

B. REQUEST FOR ACADEMIC CATALOG . . . . . . . . . . . . 260

C. STEWART'S MODIFIED TYPES OF ENGLISH MAJOR CURRICULA AMONG THE 2000-2001 CCCU MEMBERS . . . . . . 261

D. EVIDENCE OF CHRISTIAN THOUGHT AMONG SELECTED CCCU ENGLISH CURRICULA . . . . . . . . . . . . . . . 266

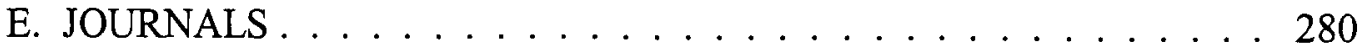

REFERENCE LIST . . . . . . . . . . . . . . . . . . . . . . . . . 319

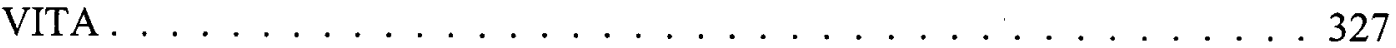




\section{LIST OF ILLUSTRATIONS}

1. Eisner's Four Dimensions of Education Criticism . . . . . . . . . . . . 61

2. Descriptive Dimension of Curricular Analysis: "First Look" Card

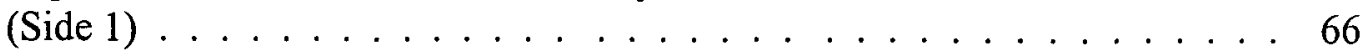

3. Descriptive Dimension of Curricular Analysis: "First Look" Card

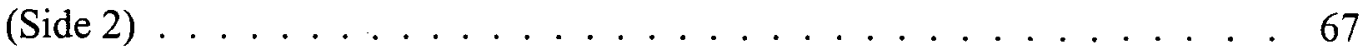

4. Descriptive Dimension of Curricular Analysis: "Claims" Card

(Side 1$) \ldots \ldots \ldots \ldots \ldots \ldots \ldots$. . . . . . . . . . . . . .

5. Descriptive Dimension of Curricular Analysis: "Claims" Card (Side 2) . . . . 72

6. Descriptive Dimension of Curricular Analysis: "Content Organization" Card

(Side 1) . . . . . . . . . . . . . . . . . . 73

7. Descriptive Dimension of Curricular Analysis: "Content Organization"

Card (Side 2) . . . . . . . . . . . . . . . . . . . . 74

8. Descriptive Dimension of Curricular Analysis: "Content Categories and Emphases" Card (Side 1) . . . . . . . . . . . . . . . 75

9. Descriptive Dimension of Curricular Analysis: "Content Categories and

Emphases" Card (Side 2) . . . . . . . . . . . . . . . . 76 


\section{LIST OF TABLES}

1. Criteria for Purposeful Sampling of CCCU English Curricula . . . . . . . . . 55

2. Percentage of Literature in Type 1.0 Curricula in CCCU

Purposeful Sampling $(N=11) \ldots \ldots \ldots \ldots$. . . . . . . . . . . . .

3. Percentage of Literature in Type 1.5 Curricula of CCCU

Purposeful Sampling $(N=4) \ldots \ldots \ldots$. . . . . . . . . 91

4. Percentage of Literature in Type 2.0 Curricula of CCCU

Purposeful Sampling $(N=5) \ldots \ldots \ldots \ldots$. . . . . . . . . . . . . .

5. Three Most Recurring Introductory Claims Among Sampled

CCCU English Curricula $(N=20) \ldots \ldots \ldots$. . . . . . . . . . 97

6. Intellectual Goals Cited and Implied Among Sampled

CCCU English Curricula $(N=20) \ldots \ldots \ldots$

7. Curricular Types and Structures Among Sampled

CCCU English Curricula $(N=20) \ldots \ldots \ldots \ldots \ldots$

8. Vestiges of Field Coverage in Selected Types and Structures of CCCU

English Curricula . . . . . . . . . . . . . . . . 108

9. Content Category Ranges for Type 1.0 English Curricula in Sampling $(N=11)$. . 113

10. Content Category Ranges for Type 1.5 English Curricula in Sampling $(N=14)$. . 117

11. Content Category Ranges for Type 2.0 English Curricula in Sampling $(N=5) \ldots \ldots \ldots \ldots \ldots \ldots$

12. Increase of Writing Programs Among Purposeful Sampling of CCCU

English Curricula $(N=20) \ldots \ldots \ldots \ldots \ldots \ldots$

13. Faculty Supporting Writing Programs Among Purposeful Sampling of

CCCU English Curricula $(N=20) \ldots \ldots \ldots$

14. Shakespeare Course Required Among Purposeful Sampling of CCCU

English Curricula $(N=20) \quad \ldots \ldots \ldots \ldots$ 
15. Total Courses for Type 1.0 English Major in Purposeful Sampling of CCCU Curricula $(N=11) \ldots \ldots \ldots \ldots$. . . . . . . . . . 134

16. Total Courses for Type 1.5 English Major in Purposeful Sampling of CCCU Curricula $(N=4) \ldots \ldots \ldots \ldots \ldots \ldots$

17. Total Courses for Type 2.0 English Major in Purposeful Sampling of CCCU Curricula $(N=5) \ldots \ldots \ldots \ldots \ldots \ldots \ldots \ldots$

18. Historical Coverage of Literature Excluding Initial Surveys in Purposeful Sampling of CCCU English Curricula $(N=20) \ldots \ldots$

19. TESOL and Related Offerings Among CCCU Purposeful Sampling $(N=20) \ldots 138$

20. Writing Programs Among CCCU Purposeful Sampling $(N=20) \ldots \ldots \ldots$

21. Leading Weaknesses Among CCCU Purposeful Sampling $(N=20) \ldots \ldots \ldots$

22. Introductions to Curricula in Purposeful Sampling of CCCU

English Curricula $(N=20) \ldots \ldots \ldots \ldots \ldots \ldots$

23. Introductions to English Curricula in a Random Sampling of CCCU

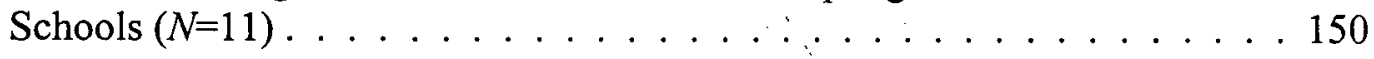

24. Literary History/Theory and Literary Criticism Among Type 1.0

English Curricula $(N=11) \ldots \ldots \ldots \ldots \ldots \ldots$

25. Literary History/Theory and Literary Criticism Among Type 1.5 English Curricula $(N=4) \ldots \ldots \ldots \ldots \ldots \ldots$

26. Literary History/Theory and Literary Criticism Among Type 2.0

English Curricula $(N=5) \ldots \ldots \ldots \ldots \ldots \ldots$

27. Seminar/Capstone Courses Among Type 1.0 English Curricula $(N=11) \ldots \ldots$

28. Seminar/Capstone Courses Among Type 1.5 English Curricula $(N=4) \ldots \ldots 2$

29. Seminar/Capstone Courses Among Type 2.0 English Curricula $(N=5) \ldots \ldots 3$

30. Internship and Practicum Courses Among Type 1.0 English Curricula $(N=11) \ldots 165$

31. Internship and Practicum Courses Among Type 1.5 English Curricula $(N=4) \ldots 166$

32. Internship and Practicum Courses Among Type 2.0 English Curricula $(N=5) \ldots 167$ 
33. Recurring Evidence of Christian Thought in Purposeful

Sampling of CCCU English Curricula $(N=20) \ldots \ldots \ldots \ldots$. . . . . 174

34. References to Christian Thought in Type 1.0 Gordon College

English Major Curriculum . . . . . . . . . . . . . . . . . 184

35. References to Christian Thought in Type 1.0 Lee University

English Major Curriculum . . . . . . . . . . . . . . . . . 185

36. References to Christian Thought in Type 1.5 Malone College

English Major Curriculum . . . . . . . . . . . . . . . . . 188

37. References to Christian Thought in Type 1.5 Dordt College

English Major Curriculum . . . . . . . . . . . . . . . . . 190

38. References to Christian Thought in Type 2.0 Simpson College

English Major Curriculum

39. References to Christian Thought in Type 2.0 Seattle Pacific

University English Major Curriculum . . . . . . . . . . . . . . . . . 195 


\section{LIST OF ABBREVIATIONS}

ADE Association of Departments of English

CEA College English Association

CCCU Council for Christian Colleges and Universities

MLA Modern Language Association

NCTE National Council of Teachers of English 


\section{ACKNOWLEDGMENTS}

St. Anselm of Canterbury, the medieval theologian, prayed that Christ "by [his] powerful kindness [would] complete/what in my powerless weakness I attempt," a plea any dissertating Christian may appreciate. Certainly I must confess the Lord's goodness, mercy, guidance, and patience which He has extended through many individuals during my prolonged doctoral studies. I profoundly thank Him and all through whom He helped me to do this study. Grouping their names within several categories may help me include every contributor to this dissertation.

Andrews University faculty and staff deserving my whole-hearted appreciation include those who have taught me in and out of the classroom, especially Dr. Lyndon G. Furst, Dean of Graduate Studies and my committee chairman, whom I thank profoundly for his instruction, kindness and patience; School of Education faculty, Drs. Judith Anderson, Paul Brantley, and especially Dr. Larry Burton who graciously served on my committee, and Mrs. Anna Pizkozub who tracked my progress; English Department faculty, especially Dr. Douglas Jones who also kindly served on my committee; Mrs. Bonnie Proctor who carefully reread drafts of this work; and, Mrs. Barbara Huston who

kindly arranged meetings with my advisor and committee. Finally, the librarians and staff of the James White Library at Andrews University deserve considerable thanks.

Bethel College faculty and staff meriting my sincerest gratitude include four colleagues whose consistent encouragement and prayers caused me to persevere when I 
would have abandoned this study: Dr. Christian Davis, my former divisional chairman, who prayed for me and taught extra classes to lighten my teaching load; Dr. Timothy Paul Erdel, my team-teaching partner, whose belief that I would complete this dissertation far exceeded my own and whose kindnesses proved innumerable; Dr. Elizabeth Hossler, whose interest and support proved unflagging; Dr. Michael L. Holtgren, Dean Emeritus, whose encouraging words proved timely; Dr. Bernice Schultz Pettifor, Professor Emerita, whose mentorship and friendship I will forever value; and, the late Professor Evelyn R. Slavik, my former chairwoman, whose scholarly integrity I shall ever hold in high regard.

Other Bethel faculty deserving my gratitude include Kim Peterson, writer-atlarge, who dangled our partially completed novel as incentive to finish this work; Dean Alesha D. Seroczynski, who kindly lightened my teaching load; Dr. Robert Staples, current chair of our department, who persistently inquired, "How's your dissertation coming?"; and, Dr. Stanley M. Taylor, Professor Emeritus, who often advised, “Just take your dissertation step-by-step." All my Bethel colleagues in English and other disciplines deserve my sincere gratitude for their encouragement.

Bethel's librarians and their staff also deserve my sincere gratitude, especially Mr. Mark Root, M.L.S., who graciously secured innumerable articles used toward this study, and Dr. Clyde Root, whose leadership has brought the Bowen Library respect among Christian colleges and universities. I could not have done this research study without the resources of the Bowen Library and its connections to other libraries including the Indiana University South Bend, Michigan State University, Notre Dame libraries, and the Online Computer Library Center (OCLC). 
Nor could I have done it without the support of Bethel's support staff, especially Mrs. Beda Dodge, head of Institutional Technology, whose help included the amazing gift of a "pen drive" to hold a complete electronic version of my dissertation. Mrs. Hope Olson, former secretary to the Language and Literature Division, typed and formatted several charts. Mrs. Mary Boise, current secretary to the English Department, re-typed several sections of this document, collated several versions, designed dissertation defense transparencies, and greatly encouraged me through its completion. I owe both these amazing secretaries many words of appreciation and several lunches.

Bethel College students have supported my dissertation efforts through their prayers, encouraging words, and through the special gift of a laptop computer. How could I ever convey to them, especially the Freshmen Year Experience "Block 3" students, the gratitude I have for their help? They represent the most caring and giving students I have ever met during my teaching career. Several of them deserve particular mention: Holly Birkey prayed for me and encouraged me as she assisted in the English office; Britney Grey transformed my rough sketch into a polished illustration of Eisner's Education Criticism; Ashley Hayes rescued me when I needed computer help, gave me her opinion whenever I asked for it, and offered many words of encouragement; and, Dan Hill led the undercover campaign to give me a laptop computer. Finally, English Writing major Michelle Lewis completely formatted this work (no small task!), edited it, and eased my anxiety that it might never come to completion. To them all, and others who prayed for me and helped me, I owe great thanks!

Friends and family greatly encouraged me during this study, including these former Bethel faculty friends: Professors Terry Lawrence, Kathryn Paschall, Della 
Herman Trudgen, and Kirk Weller. Visiting Professor Janet L. McCann of Texas A \& M University and Mrs. Lori Albanezzi Weller made me believe I could do this work. My late parents, Lloyd and Winifred Crandon, still inspire me to educate myself. All my close family members have encouraged me through this dissertation process, especially my aunts Mrs. Ruth C. Bowman and Professor Janet L. Navin. The latter kept my courage up through the sticky points, and even proofed my various drafts.

Finally, I wish to reiterate my appreciation to my committee members now serving at Andrews University: Chairman Lyndon G. Furst; Dr. Larry Burton; and Dr. Douglas Jones. Also, I extend special appreciation to Dr. Delmar Davis, the external reader on my committee, whose book Teaching Literature: A Seventh-Day Adventist Approach will help shape my answer to this question: What should comprise the Christian college English major curriculum?

I hope I have mentioned everyone who has helped me create this document; if I have failed to mention any name(s), I ask for pardon. I aver that I have tried to produce a work reflecting sound scholarship, but I realize error may have entered it; if so, any mistakes remain only my own. As Chaucer concluded The Canterbury Tales, "[If] ther be any thyng that displese ... . I preye [it be arretted] to the defaute of myn unkonnynge and nat to my wyl."

Maralee S. Crandon

South Bend, Indiana

December 29, 2007 


\section{CHAPTER I}

\section{INTRODUCTION}

Though major change characterized the English discipline near the end of the 20th century, prompting Peter Elbow's (1990) retrospective study What Is English? and its numerous parodies, the undergraduate English major remained essentially untouched (Applebee, 1996; Graff, 1992; Huber, 1996). In form and content, claimed leading voices in English curriculum, the 1990s college English major differed little from its late 1960s counterpart described by Thomas Wilcox in $A$ Comprehensive Survey of Undergraduate Programs in the United States (1970). Reporting to the professional organizations which initiated his study, and to the (then) United States Office of Education which underwrote it, Wilcox had portrayed the undergraduate English curriculum as dominated by literature, and cited the sophomore literary survey as its "staple" course (pp. 158-163). Wilcox underscored that curricular orientation toward literature when he titled his later, in-depth analysis of the survey results The Anatomy of Literature (1973). The undergraduate English major, as Wilcox found it, meant essentially the study of British, American, and (perhaps) world literatures, their respective literary periods, various genres, and notable authors.

After the Wilcox foundational study established this baseline for the college English major curriculum, subsequent studies showed literature remaining the favored or privileged component of the undergraduate English major through the 1970s and 1980s 
(Applebee, 1996, p. 28; Harris, 1986, p. 26; 1988, pp. 10-11; Stewart, 1989, p. 192; Waller, 1986, p. 32). Studies initiated by the two leading professional English organizations revealed the continuing hegemony of literature-termed "privileging" by English scholars - over other branches of the discipline - despite internal and external stresses on the curriculum. At the close of the Vietnam War, when technical and practical courses (such as editing) gained influence in the undergraduate curriculum, Cowan (1975) reported to the Association for Departments of English (ADE) and its parental body, the Modern Language Association (MLA), that literary studies still dominated 23 selected programs featured in her study. So, at the peak of undergraduate English enrollment, literature ruled the college English major (Huber \& Young, 1986, p. 40).

During the early 1980s when the Boyer Report focused national attention on "the basics" throughout American education, a putative drop in undergraduate English enrollments prompted the $\mathrm{ADE}$ to survey departments among larger institutions (Huber \& Young, 1986, p. 40). Although this study found mixed patterns and could not discern a significant drop in English enrollments, it did identify (for the first time) "nine branches of English studies" administered by English faculty (p. 41). Foremost among the nine was literature, specifically British and American literature (p. 41). So amidst the various stresses of the early 1980s, literature remained the main emphasis of the undergraduate English major much as it had when Wilcox described it in 1970.

That dominance continued into the mid-to-late 1980s even while the English discipline experienced critical change. Despite the explosion of the established literary canon (of Western, white-male writers), the proliferation of literary theories, and the rise of the New Rhetoric or writing/composition studies, the undergraduate major remained 
essentially unaffected. According to Harris (1986), then chairperson of an ADE ad hoc curriculum committee, "literature [remained] at the core of the major" (p. 26). Having studied 81 academic catalogs of selected, 4-year schools, his committee found the persistent dominance of the traditional "tripod" model of English which privileged literature over its other "legs"-namely, grammar and composition (pp. 26-27).

Significantly, committee members confirmed that the "basic configuration of the English major [appeared] to have changed only slightly since $1965-68$, the period of the Wilcox study" (pp. 26-27). Huber and Young's (1986) ADE complementary study of selected English departments confirmed that conclusion: literature had maintained its long reign.

Following those ADE reports, Donald C. Stewart (1989) began his qualitative study of 194 undergraduate English major curricula issued by both public and private institutions throughout the United States ("What Is an English Major?"). As Stewart performed the first categorization of undergraduate English programs, he found literary studies had maintained their dominance; two of the four categories represented curricula dominated by literature. The first group he termed "straight literature" (a non-political phrase); these curricula numbered merely 11 (p. 190). The second group represented what Stewart termed "more flexible" curricula and numbered 107-more than half of his sample (p. 190). Literature, to use an exhausted metaphor, remained the "queen" of English studies throughout the 1980s (Berube, 2002, p. 21).

This hegemony had, of course, its critics among the English profession. From the Harris (1986) ADE ad hoc committee came two protests: Waller (1985) indicted faculty for the lack of professional discourse about the undergraduate English major, and Lawrence (1988) condemned the major for its evident rigidity. Both members recognized 
an impervious core to the traditional English curriculum: "essential" or required literary courses structured to "cover" time periods of Western literature (Lawrence, 1988, pp. 1415; Waller, 1986, pp. 32-33). This structural concept of the major-a change-resistant literary core surrounded by a periphery of additional courses-appeared more fully explained in Graff's Professing Literature (1987) and Beyond the Culture Wars (1992).

Graff (1987) attributed that professional silence which Waller assailed not to willful negligence, but to the widespread use of the "field-coverage model of departmental organization" which separated the curriculum and its professors discretely according to their respective historical eras and genres (p. 6). This administrative practice, Graff (1992) later claimed, resulted in perpetuating the "patterned isolation" which discouraged both collegial discourse and constructive conflict (p. 133). Ryken (1991) also rued that lack of discourse. He regretted that "the isolation of literary study," particularly after critical theories proliferated in the 1980 s, had left literary scholars "[unable to] communicate across the chasms of their own discipline" (p. 294). Thus, the administrative use of "field coverage" for the English curriculum and the concomitant silence among its academics helped make the major static.

Field coverage also contributed, Graff (1992) thought, to the rigidity of the undergraduate English curriculum: Its required literary core courses remained stable, while its periphery of added electives grew. Additions reflected contemporary developments within English studies; by the late 1980s when the Writing Across the Curriculum movement had been established and rhetoric revitalized, composition/writing enlarged the periphery with such courses as "The Professionalization of Composition Studies" (McQuade, 1992, pp. 508-510). While the periphery absorbed the new, the old 
core of the curriculum remained effectively impervious to change. As Graff pictured this effect of "the field-coverage principle," he noted that change and "innovation even of a threatening kind could be welcomed simply by adding another unit" $(1987$, p. 7$)$ at "the edges of the curriculum" (1992, p. 23). Should the periphery grow excessive, then dated studies such as philology could be eliminated (Waller, 1986, p. 33). Thus, the 1980s undergraduate English major with its petrifying core and swelling periphery might be named "the turgid model" of English.

While Waller, Graff, and other educators signaled the pressing need to debate the curriculum, "a coalition of eight major professional organizations in English" in 1987 convened 60 English educators to interact on the discipline and profession (Elbow, 1990, pp. 3-4). Representing all levels of English instruction, they did not focus on any one specific curriculum; yet they significantly affected college English through Elbow's professional journal of the conference-a journal entitled, provocatively, What Is English?

The title of this MLA publication acted as a clarion call to debate the nature and direction of undergraduate English; parodied titles multiplied (including Stewart's 1989 study, “What Is an English Major, and What Should It Be?"). For Elbow, who was educated as both a literary and a composition scholar, the future of undergraduate English appeared to lie through a new design in which "writing could serve as a paradigm for English" (pp. 130-131). In a sense, Elbow pushed the door open wide for composition/writing to rewrite the English major.

Considerable attention to the roles of writing in the English curriculum followed the 1987 English Coalition. The MLA issued not only Elbow's What Is English?, but also 
a more formal report by Lloyd-Jones and Lunsford (1989), which posited the centrality of writing/composition studies as well as the role of non-traditional literature. Subsequently, the MLA-related ADE also devoted its Fall 1990 ADE Bulletin to coalition reports and responses, including Armstrong's (1990) articulation of five coalition goals proposed for the undergraduate major. These were predicated upon the "prominent use of writing as a means of inquiry," as important a means as literature (p. 32). The growing import of writing received telling support from literary scholars Greenblatt and Gunn (1992) in their seminal work Redrawing the Boundaries: The Transformation of English and American Literary Studies, which examined the past, present, and future roles of writing composition in the undergraduate major. McQuade's (1992) essay in Redrawing the Boundaries concluded with a polemical call to balance writing and literature in college English (pp. 515-516). Such texts at the opening of the 1990s suggested that the undergraduate English major would soon see significant curricular reform.

Indeed, leading literary voices throughout that decade called for major curricular reform. First, Graff (1992) issued his full-blown prescription for reform: He averred that since conflict was then characterizing the English discipline, its curriculum should "teach the conflicts" ranging across it even into other disciplines. Such a curriculum, he claimed, would prove more coherent than the traditional, core-and-periphery model (that had privileged literature) even as his conflicts-model would foster dialogue throughout the academic community.

The dialogue-conscious Applebee (1996) issued his proposed reform for the undergraduate English major, a work entitled Curriculum as Conversation, which called for "emphasis on ... knowledge-in-action" rather than "knowledge-out-of-context" (p. 
3). Students, he proposed, should learn to participate in "the discourse conventions that govern" learning (p. 31). Whereas his proposal reflected the influence of and agreement with Graff's reform, Applebee's plan lacked concreteness. Scholes (1998), however, offered a design having remarkable specificity; in The Rise and Fall of English, Scholes proposed the reconstruction of "English as a discipline of textuality" (p. 146). Its curriculum, he posited, should be based on four elements of textuality: "theory, history, production, and consumption" of texts (p. 147). So, during the 1990s, these three influential scholars pointed out various ways to reform undergraduate English.

They basically ignored, however, James Berlin, a writing/composition scholar who advocated curricular reform through rhetoric. Berlin's (1996) work, Rhetorics, Poetics, and Cultures: Refiguring College English Studies, published posthumously by the NCTE, protested the sustained refusal of such leaders as Graff to recognize the impact of their ignoring Berlin's rhetorically based curriculum to perpetuate instead one dominated by literature (pp. 14-15). Castigating his opponents' putative agenda, Berlin wrote:

By excluding reading practices that might discover the political unconscious of literary texts and by refusing to take seriously the production and interpretation of rhetorical texts that address political matters, English studies has served as a powerful conservative force, all the while insisting on its [transcending] the political. (pp. 1415)

Whether Berlin's "social epistemic rhetoric" sounded too populist or leftist to those he accused, they continued to ignore him and his work. For instance, Graff (1996) and his fellow discussants omitted any mention of rhetoric, much less of Berlin's populist rhetoric, during their round table discussion on the need for coherence in English and its 
curriculum (Smithson \& Ruff, 1994). Though Graff argued for reform, he and the other discussants evidently dismissed revolution.

But pointing ways to reform is not equivalent to effecting reform. Despite the efforts of the leading professional organizations to promote curricular revision or reform during the 1990 s, no sweeping movement appeared to transform the undergraduate English major. Though the NCTE launched its Refiguring English Studies series, which included Berlin's last work, reform did not accelerate. The MLA, meanwhile, instituted a federal curricular review program entitled the "Fund for the Improvement of Secondary Education" (FIPSE), an effort urging undergraduate English curricula reform as a means to enhance the preparation of high-school English teachers.

FIPSE funding led to numerous case studies without inciting widespread reform in the English major (e.g., Mason, 1994; Schroeder, 1993). FIPSE consultations on the involved campuses, observed MLA president Spacks (1993), found two common but difficult pressures countering change: first, "financial constraints that severely [restricted] possibilities for fresh teaching initiatives"; and, second, "internal ideological conflict ... [especially from] faculty members profoundly committed to traditional approaches" (pp. $3 \& 4$ ). The tenor of this presidential address to the 1992 MLA-FIPSE conference conveyed the distinct tone of frustration despite its "qualified optimism" (Spacks, 1993, p. 8), and that optimism-however limited - proved unwarranted. Beyond producing individual case histories of revised or reformed curricula, FIPSE failed to ignite widespread curricular reform.

In addition to its fizzled FIPSE project, the MLA funded two surveys concerning undergraduate studies: First, a survey focused on three, upper-division courses (Huber, 
1996); and, second, "a comprehensive examination of the English curriculum in 199091" (Huber, 1996). The initial survey and report had a narrow focus, certainly not one underscoring reform, as evidenced by its report title: "What's Being Read in Survey Courses?" Perhaps such a constricted topic reflected, as Fleishman (1995) claimed, external political pressures exerted by such works as the 1988 Lynne Cheney report to the National Endowment of the Humanities (NEH) which criticized the English teaching profession on several counts - including a putative liberal bias in its assigned literature (Huber, 1996, p. 813).

The second 1990s MLA survey, taken in 1991 and reported upon in 1996, indicated the English major had been subjected to revision rather than reform. Huber (1996) concluded from it that "many English departments" since the 1984-85 MLA survey "had taken steps to make their majors more rigorous" by "[increasing] the number of specific courses required" (p. 67). Though this conclusion assumed that additional requirements create academic rigor, the report reflected, in six of eight tables on curricular content, the evident impact of the traditional tripod model of English. As ever, the tripod favored literature over composition and language. Categories within the six tables showed "literature" courses consistently outnumbering writing, composition, and language. Thus, Huber's report on the 1991-92 MLA Survey indicated little essential change in the undergraduate English major since the 1984-85 survey.

\section{The Problem}

That conclusion represented, at least, the interpretation I made of Huber's (1996) data: namely, that the English major appeared to have preserved its status quo. Notably, her report did not directly address the question, "What does the English major curriculum 
look like in the 1990s (as compared to the 1980s)?" Nor did her report offer a summary of findings, nor a list of promising heuristic areas. In brief, what Huber (1996) pointedly omitted was a coherent statement on the significance of the 1990-91 MLA survey of the English major. As it failed to illuminate the state of the undergraduate English major overall, Huber's report certainly did not address its status in the small, private liberal arts college, much less the small, private, Christian liberal arts college. Indeed, Huber's (1996) definition of "small" in the context of enrollment varied from chart to chart, making interpretations based on institutional size difficult. However, in the majority of tables, "small" meant 2,000 or fewer students; on occasion (e.g., Table 45), the least category of institutional size meant 5,000 or fewer students. Thus, once again, a survey and report undertaken by a professional organization of English academics provided no data on the English curriculum among smaller, private, religious-oriented colleges and universities. Further, Huber's report did little at all to illuminate the status of the English major curriculum across the nation.

Despite scholarly cries for the reform or refiguring of the English major during the 1990s, including the Berlin (1996) polemic and the Scholes (1998) apologia for textual studies, the curriculum received minimal attention from an MLA subservient body, the Association of Departments of English (ADE), in its first report of the new century. Less than one complete page of its "Report of the 2001-2002 ADE Ad Hoc Committee on the English Major" (Schramm, Mitchell, \& Laurence, 203) addressed the undergraduate curriculum. This brief treatment, moreover, relied on anecdotal evidence given by an unspecified number of "Chairs of ADE-member departments" who responded to this rather broad, but biased question: "Have there been curricular changes 
in [your] department or college that have affected the number of students majoring in English?" (p. 83). The ambiguity of this report-reflected by vague, uncredited references such as "cited by several chairs" (p. 83), "Some departments" (p. 84), and "One member of our committee says" (p. 84)—underscored the committee's indifference toward curricular reform. As its 1996 MLA researcher(s) had done, this 2001-2002 ad hoc committee indicated the issue of curricular reform had been minimized by the MLA organization.

Within the professional milieu at the new century's opening, the MLA did publish six case studies in its supplemental publications, the ADE Bulletin and the Profession series, which tended to promote two ideas: (a) developing increased coherence within the undergraduate major (Culler, 2003; Moffat, 2003; Shepard, 2003); and (b) creating greater integration of English studies within the major (Francus, 2001; Shepard, 2003; Weber, 2001). Other case-like studies expressed pragmatic concern for increasing student enrollment in the major through (a) critical or analytical methods (Moffat, 2003; Weber, 2001) and (b) faculty assignments and advising (Journet, 2001; Weber, 2001). These studies had the collective effect, I believe, of making the MLA appear as if it were tackling the curriculum reform issue while actually stifling it.

However one interpreted the recent attention given to case studies, the ambiguity of the most recent ADE/MLA study (2003), or the opaqueness of its predecessor (Huber, 1996), the English curriculum within the small, private Christian liberal arts college at the start of the 21 st century remained essentially unstudied. That situation prompted this dissertation: namely, that no research has been published on the composite English curriculum offered among Christian liberal arts schools. Only one dissertation in the past 
40 years has treated the college English major in that milieu-namely, Peck's (1969) survey of undergraduate English programs among the (then) United Presbyterian Church colleges. Even as Peck researched English programs of various types, he did not focus in depth on the major itself. That fact, plus the age of Peck's study and the narrow scope of his universe, limited the usefulness of his work to this study.

Most of the available research about the undergraduate English curriculum has excluded smaller institutions whose full-time enrollments (FTE) fell below 2,000. Though Wilcox (1970) did include data from small, baccalaureate, liberal arts schools (because his survey was comprehensive), he did not identify Christian liberal arts schools in a discrete category. Subsequent MLA, ADE, and NCTE studies did not attempt to be as comprehensive or as specific; for instance, the MLA 1990-91 survey categorized "small" as under 2,000 FTE. Besides excluding smaller schools, the post-Wilcox studies tended to omit religious institutions from their data collections. As a result, research about the small, private, Christian liberal arts English major and its curriculum has not been available.

\section{Purpose of the Study}

The purpose of this dissertation was to make an initial exploration of the undergraduate English curricula published among the 101 schools comprising the 20002001 Council for Christian Colleges and Universities (CCCU) (http://www.cccu./org); to describe and categorize those curricula; to make preliminary observations about them; to determine evidence of Christian thought within them; to construct a tentative composite of their aggregate English major; to make the resultant findings available as a reference 
resource for curricular revision by other English faculty; and, to encourage further research of the undergraduate English curricula among Christian liberal arts schools.

\section{Significance of the Study}

The importance of this study to the Christian college and university lies in what it offers English faculty: (a) an initial attempt to examine the nature and state of the undergraduate English curriculum within Christian liberal arts schools; (b) an initial categorization of the English undergraduate curricula among CCCU schools with full membership during 2000-2001; (c) an analysis of 20 selected CCCU English curricula comprising a purposeful sampling chosen for certain institutional characteristics; (d) a model to encourage the review and revision of the undergraduate English curricula, with particular concern for Christian thought and issues; and (e) a call for further research into this subject.

First, this study serves as the initial foray into unknown territory - that of the Christian college or university English major curriculum. No researcher has attempted to describe or to chart the terrain of this particular area; only one has described a similar territory, namely English curricula held among denominational schools unaffiliated with the evangelical-Protestant-oriented CCCU (Peck, 1969). Therefore, this study provides a first exploration, an overview of the individual curricula and aggregate $\mathrm{CCCU}$ undergraduate English curriculum. (Note: This study is independent of that particular organization.)

Second, this dissertation makes the initial categorization of the 2000-2001 CCCU undergraduate English curricula, and a descriptive analysis of 20 purposefully sampled curricula. As such, the study addresses the usual elements of curriculum analysis such as 
type or category, claims, aims or goals, structure, courses, emphases, omissions, notable features, weaknesses, and strengths. Other concerns addressed by this study include the identification of any extant themes, patterns, and models (such as the field-coverage model) which appear to characterize individual as well as the aggregate undergraduate English major curricula. Central among these curricular concerns in this study, however, is the detection of Christian thought and/or issues evident within the official, published curricula of CCCU members.

Third, this study offers an analysis of 20 selected CCCU English curricula, whose institutions were chosen on the basis of geographic location, religious affiliation or heritage, and size of student enrollment. Every geographic region of the USA is represented; 12 of 34 denominations or affiliations are represented; and institutions having enrollments under 600 , under 1,300 , under 2,000 , and over 2,000 are included among the purposeful sampling. Among the lesser reasons for some institutions being chosen include theological orientations, such as Arminian or Calvinist heritages, and my own regard for certain schools, including competitors to my own college.

Fourth, this present study provides (I hope) a catalyst for faculty engaged in the review and revision of English curriculum within Christian liberal arts institutions. Having established a baseline with its collected data and an initial interpretation of those data, this dissertation may help English faculty within such schools make curricular observations-especially comparisons and contrasts. This study may also help with the revision process through its treatment of the various curricular elements and dimensions, and through its concern for Christian thought being evident in the published curriculum. 
Fifth, this study calls for further research addressing not merely the nature and state of individual curricula and aggregate curriculum, but larger issues such as the theory(ies) informing the CCCU English curricula, the challenges affecting their roles and currency, and especially their inclusion of Christian thought and issues.

\section{Research Questions}

Two overarching research questions prompted this present study: (a) What was the nature and state of the undergraduate English major curriculum within Christian liberal arts colleges and universities, specifically among the member schools of the 20002001 Council for Christian Colleges and Universities (CCCU)? and (b) What evidence of Christian thought and influence appeared among the individual CCCU English major curricula, and so within the aggregate curriculum?

Subservient to the first research question about the nature and state of the English curriculum were the following questions:

1. How did the content of these individual curricula and their aggregate curriculum correspond to Stewart's Modified Categories of English Majors? That is, what were their types and how did they compare to Stewart's (1989) findings?

2. What claims appeared among these CCCU English curricula, and did any claim(s) dominate? What assumptions were discernible about the purpose(s) and role(s) of the English major curriculum? What themes (if any) were evident?

3. What goals, aims, and objectives (if any) appeared? How were they articulated? What vestiges (if any) did they suggest?

4. How were the curricula organized, and how was the aggregate curriculum structured? What vestiges (if any) of earlier structures remained? 
5. What content appeared in the CCCU curricula and its aggregate English major curriculum? What categories (if any) received emphasis, and which little or no attention?

6. What patterns appeared within the content of these CCCU English curricula?

7. What curricular weaknesses and strengths, as well as slights and emphases, appeared among the individual curricula and the CCCU aggregate English curriculum?

\section{Theoretical Framework for Curricular Analysis}

Although Stewart's (1989) initial classification of undergraduate English majors prompted this present study, Eisner's $(1985,1991)$ theory of education criticism and connoisseurship provided the theoretical framework which readily subsumed Stewart's categorization into its own approach. This study rests on Eisner's theory especially as he expressed it more fully in the later work, entitled The Enlightened Eye: Qualitative Inquiry and the Enhancement of Educational Practice (1991). Eisner's critical approach, according to the Handbook of Qualitative Research (Schwandt, 1994), belongs to the constructivist paradigm of inquiry: "Eisner assumes that perception is . . . theory dependent and that knowledge is a constructed (versus discovered) form of experience" (p. 129). An explanation of Eisner's theory, with an original illustration of its form and function, appears below in chapter 2; my application of his theoretical framework appears in chapter 3. General terms associated with Eisner's work and curriculum appear below.

\section{General Terms}

The following terms are defined as used in this study:

Close reading: This type of reading "attempts to discover the meaning of a text by focusing on the language of the text itself, its rhetoric, syntax, tone, and structure. . . 
[It] asks questions about how formal aspects of the text-such as word choice, word order, and even line length-may shape meaning" (Edmonds, 1994, p. 194).

Curriculum: This represents "a series of planned events that are intended to have educational consequences for one or more students" (Eisner, 1985, p. 45). Eisner called this a working definition (p. 45), but his use of the term reflected a "contemporary [understanding of] the curricular field as discourse, as text" (Pinar, Reynolds, Slattery, \& Taubman, 2004, p. 7).

Document: This is "the medium on which [a] message is stored" (Jupp, 1996, p. 299).

Evaluation: This constitutes the application of educational criteria to a work, as performed by an educational critic cognizant of the values he or she both recognizes and rejects during that application (Eisner, 1985, p. 236).

Journal writing or journaling: This is 'the use of writing to 'think out loud' on paper," and according to Toby Fulwiler, it may "“promote introspection on one hand and vigorous speculation on the other" (quoted in Gannett, 1994, p. 682).

Rhetoric: "The study of speaking and writing well, a ... program of instruction involving theory and practice and aimed at the moral and intellectual development of the student" (Fleming, 1998, p. 172).

Text: The symbolic and coded "analytical phenomena" decipherable through codes and "interpretive frames" (Manning \& Cullum-Swan, 1994, p. 467). In this study, by text I mean a written document containing symbols such as letters, words, and numbers which invite the reader to interpret in the context of its nature and situation. 


\section{Premises}

Eisner (1991) identifies seven premises underlying his theory, five of which pertained to my research; these appear paraphrased below:

1. There are multiple ways of knowing.

2. Knowledge is constructed.

3. Constructed knowledge develops into forms that influence what people see and report.

4. Effective use of any form demands intelligence.

5. Selection of a form influences the selector's experience (Eisner, 1991, pp. 7-8).

Applying these premises to this study, I better understand that my educational experiences in literary criticism, rhetorical expression, and curricular study have directed my perception, comprehension, evaluation, and articulation of the CCCU undergraduate English curriculum.

\section{Qualitative Features}

The six features or aspects of qualitative study which Eisner presented appear below (in abbreviated, paraphrased form):

1. "Field focused"-Observers go to the places, situations, and/or artifacts under study (Eisner, 1991, pp. 32-33). In this study, printed curricula were documents or artifacts to be observed, described, and appraised.

2. "Self as an instrument"- My honed, sensible, and personal understanding led to seeing "what counts" and to reasoning not from one "right" view, but "from multiple views" (Eisner, 1991, pp. 34-35). For this study, I attempted to look at each curriculum, 
especially the 20 in the purposeful sampling, from more perspectives than the one I developed when leading a revision of the English curriculum at a CCCU member school (i.e., Bethel College, IN). Journaling about the 20 selected curricula represented one of my major tools.

3. "Interpretive character"-One sense Eisner (1991) gave "interpretation" within qualitative study was the attempt by "inquirers [to] account for [what] they have given an account of" (p. 35). Through this research study, I have sought to present an account of CCCU English curricula and their resulting aggregate curriculum; I have also tried to support my findings with reasoning.

4. "Use of expressive language and the presence of voice in the text"-Like Eisner (1985, 1991), I have used the first-person point-of-view, and I have tried to write effectively.

5. "Attention to particulars"-Eisner (1991) explained that, "In the particular [detail] is located a general theme" (p. 39), a concept familiar to literary critics, who practice "close reading" as a basic tool whatever their critical approach. Through acute attention to repetitions, contrasts, and anomalies within the texts studied, I have posited the nature and state of the aggregate English curriculum.

6. Credibility-As Eisner (1991) did not specify a term for "criteria for judging," I suggested "credibility" or "believability" (p. 39). Under this feature, he grouped three evaluative criteria: "coherence, consensus, and instrumental utility" which also deserve basic explanation for this present study.

By "coherence," Eisner referred to the "tightness of [the] argument presented" (1991, p. 53). Coherence involved all the following: the use of "multiple data sources," 
the congruence of observations, the explanation of anomalies, the recognition of "other credible interpretations," and the relationship of one's findings "to what one already knows" (Eisner, 1991, p. 53). In this research study, I worked toward coherence primarily through a systematic analysis of all $(N=98)$ English curricula offered among the 101 CCCU schools; thus, I categorized the 98 curricula according to type. Also, I strove toward coherence by an in-depth analysis of 20 selected curricula.

By "consensus," Eisner (1991) meant agreement among experts in a particular field, such as the art or the educational field. "With respect to qualitative research and evaluation," he explained, "affirmative consensus confirms the researcher's conclusions" (p. 57). I sought consensus in this present study through comparing and contrasting my findings to: (a) the literature of the field, especially Stewart's (1989) study; (b) surveys taken by professional organizations; (c) recent case studies; and (d) the direction of my dissertation committee.

By "instrumental utility," Eisner (1991) meant the usefulness of a work residing in its comprehensiveness and its anticipation of needs or developments (p. 58). Examples helped to clarify this term: indices, maps, and guides all offer comprehensive information which anticipates future and practical usage (p. 59). I posited instrumental utility for this study through categorizing all undergraduate English major curricula (issued by the 2000-2001 CCCU members), identifying them according to Stewart's (1989) modified types. I also strove to establish "instrumental utility" for this research through the indepth analysis of $20 \mathrm{CCCU}$ curricula comprising the purposeful sampling. Beyond these procedures, journaling and then analyzing those journal entries also served to establish the "instrumental utility" of this qualitative study. 


\section{Definitions of Terms}

Several terms essential to the field of curriculum appear above under "General Terms" (pp. 17-18) and "Qualitative Features" (pp. 18-20), whereas the following terms apply specifically to Eisner's theoretical framework:

Education criticism: Arising from aesthetics, this qualitative interpretive activity, performed by an expert critic on a particular entity in education, such as curriculum, represented "the art of disclosing the qualities of events or objects that connoisseurship perceives" (Eisner, 1985, p. 223). Public disclosure proved essential, "for criticism provides connoisseurship with a public face" (Eisner, 1991, p. 85).

Connoisseurship: A heightened level of criticism, but a level without elitism or negativism, represented the contextual definition of Eisner's term, one he appropriated from the fine arts and defined as "the process of enabling others to see the qualities that a work of art possesses" (Eisner, 1991, pp. 6-7). Connoisseurship represented a honed and astute ability to perceive, describe, analyze, deconstruct, reconstruct, evaluate, interpret, and articulate an entity to a particular audience so its members better appreciate that work. In this study, connoisseurship referred to my ability to critique individual English curricula and to apprehend and draw their aggregate - the CCCU undergraduate English curriculum-and to articulate it to English faculty among Christian liberal arts colleges.

\section{Delimitations of the Study}

Three delimitations to the collection of data affected this study:

1. The documents studied represented the officially issued undergraduate English 
major curricula held by the 101 (full) "Member Colleges and Universities" of the 20002001 Council for Christian Colleges and Universities (listed in Appendix A).

2. Seventy-nine curricula appeared in printed academic bulletins and/or catalogs which I received through the mail, while 22 appeared on their respective institutional websites which I accessed electronically to make hard copies of those curricula. Though I preferred receiving printed bulletins and catalogs, I had to use off-the-web hard copies for various reasons, including an increasing reliance on electronic documents; some institutions now issue their academic bulletins or catalogs primarily through their electronic web sites.

3. The effective dates varied among the bulletins and catalogs, so that some represented 1 academic year but others spanned 2 or 3 academic years. Eighty-five of the 101 documents dated to the calendar year 2001; 15 dated to within a year of 2001, and 1 dated to within 2 years of 2001 .

\section{Summary of Chapter 1}

The first chapter of this study established its context: (a) the crisis in English studies which, for two or more decades, has defied professional consensus in defining English or delineating its boundaries; (b) the hegemony of literature within the undergraduate major; (c) the resistance to writing/composition as a means to reform the major; and (d) the ineffectiveness of professional English organizations to reform the undergraduate English major. Within that context, this chapter showed that little research had been done on the English major among Christian colleges and universities. The nature and state of the individual English curricula and their aggregate English major published by member schools of the 2000-2001 Council for Christian Colleges and 
Universities (CCCU) had not been posited; concomitantly, the presence of Christian thought or influence within that aggregate curriculum had not been sounded.

From that lack came the statement of purpose for this study: To explore the aggregate nature of the undergraduate English major curriculum held among CCCU schools at the beginning of the $21^{\text {st }}$ century, and (within that aggregate nature) to determine evidence of Christian thought or influence. The significance of this research lies mainly in its representing the initial study of that aggregate curriculum.

From the purpose to explore, then, rose the primary research questions of this study: What were the nature and state of the undergraduate English curriculum issued by the 2000-2001 members of the CCCU? What evidence of Christian thought appeared in those documents? To address these, this current study adopted two compatible research frameworks: Stewart's (1989) categorization of English majors, and Eisner's education criticism. The latter provided the major framework, challenging both my professional knowledge and my ability to analyze and interpret English curricula. I have identified terms associated with Eisner's methodology, and noted delimitations for this present research study.

Thus, chapter 1 provided the historical context, research questions, and research frameworks for this initial study of the undergraduate English major curriculum among members of the 2000-2001 Council for Christian Colleges and Universities. Although English as an academic discipline or field experienced major, paradigmatic change during the past two decades, the undergraduate English major curriculum did not keep pace but remained much as it had been in the mid-1980s: dominated by British and American literature, characterized by core course requirements, and swollen with accretive, 
peripheral electives. The MLA surveys gathered in 1983 and 1991 supported this generalization-that the undergraduate English curriculum had maintained its status quo; however, those surveys concentrated on the large, public universities, almost to the exclusion of the small, private, Christian college or university. Consequently, no data existed on the undergraduate English major within the spectrum of Christian liberal arts schools.

To address that omission, I have made this initial study of English major curricula issued by the 2000-2001 members of the Council for Christian Colleges and Universities (CCCU). Employing both Stewart's (1989) categories of English majors and Eisner's $(1985,1991)$ theory of education criticism, I present this initial exploration of the aggregate, English major curriculum held by CCCU members at the start of the new century.

Chapter 2 presents an overview of the professional literature and provides the rationale for my use of Stewart's typing and Eisner's qualitative, education criticism, as well as an explanation and original diagram of the latter's theoretical framework. Chapter 3 shows how I applied both frameworks to the CCCU curricula. Chapter 4 presents my findings, while chapter 5 interprets them, posits conclusions, and suggests further research. 


\section{CHAPTER II}

\section{REVIEW OF THE LITERATURE}

The purpose of this study was to explore the undergraduate English major curricula issued by the 101 members of the 2000-2001 Council for Christian Colleges and Universities (CCCU), to discover the nature and state of that aggregate curriculum, and to discern any evidence it gave of Christian thought. The current chapter reviews the relevant research which preceded this study_research on the college English curriculum, on curriculum theory, and within that field, research about Eisner's theory of education criticism. Finally, this chapter offers a rationale for using Eisner's education criticism as the main methodology for this study. Because scant research exists on the English curriculum among Christian colleges and universities, this chapter deals mainly with research on the condition of the English major among secular institutions.

\section{Research on the English Curriculum}

This review of literature reflected what I found characterized research on the undergraduate English major during the last five decades: types of research peaked in time waves. Around 1970, surveying and describing established what the college English

curriculum was and how its typical department appeared. This wave receded rapidly, but returned rather enervated during the mid-1980s; it then receded decidedly as the 1990s 
faded. Another wave featuring case studies arose late in the 1980s, swelled and crested in the mid-1990s, but ebbed by the mid-2000s.

Because this time wave pattern has been evident in the research of the undergraduate English major, I have used it to structure this review of literature. I have organized this review both historically and topically at once, to make the waves of research types more apparent within their respective time frames. First, I have presented the periodic surveys conducted mainly by professional English organization; then, I have shown the rising influence of qualitative studies, which, having overlapped surveys, have become for the English curriculum the dominant wave of research.

\section{Periodic Surveys Signal a Research Wave}

The seminal study for the undergraduate English major curriculum has been the Wilcox (1970) survey, representing a national survey not only of the curriculum but also of the roles, organization, functions, and practices of the English department. Conceived by the National Council of Teachers of English (NCTE) and supported by the Modern Language Association (MLA), this 1967-68 comprehensive survey was funded federally by the (then) Office of Education (p. ix).

Wilcox (1970) reported the following steps and statistics involved in his direction of this national survey of undergraduate English. First, he undertook the compiling of a complete list of "those colleges and universities [offering] four-year programs in English" (p. x). These defined the universe for the survey, but their number $(N=1320)$ necessitated his study of a random sampling $(N=300)$ (pp. x \& xii). Thirty schools representing each major type (identified according to enrollment size and governance) were included in the sampling to ensure adequate representation (Wilcox, 1970, p. xii). 
Compiling an initial list and then preparing a professional questionnaire (with the help of the Survey Research Center of the University of Michigan, of consultant William C. Budd, and sociologist Jerold Heiss) required 2 years of preparation (Wilcox, 1970, pp. xixii; 1973, p. xi).

While the questionnaire was in the process of being developed, Wilcox (1970) developed interview topics with the assistance of faculty at 63 English departments whose programs "were reported [to have] unusually high quality, [or to be] unusually effective, or unusually promising" (pp. xi-xii). Later, his team conducted on-site interviews with English faculty at those 63 colleges and universities (p. xi). These interviews provided Wilcox with anecdotal evidence and "illustrative examples" to supplement results from the questionnaire (p. xi). These later contributed, as well, to his 1973 polished version of the report, titled The Anatomy of Literature (pp. x-xi).

Wilcox conducted the national survey during the 1967-68 academic year (1970, p. $\mathrm{x})$, sending its 39 -page, mostly fill-in-the-blank questionnaire to 300 randomly sampled colleges and institutions (1970, p. xi). Its length prompted his team to award each respondent a small honorarium (p. xii). Total respondents numbered 294, for an "astonishing" return of $94.6 \%$ (p. xii). Wilcox (1970) organized both the questionnaire and its results topically, emphasizing the English department over the English major. Parts I and II of the questionnaire and resultant report treated the English department as an entity with numerous responsibilities. (Parts I and II needed 150 pages to treat the English department; Part III, in merely 30 pages, addressed "The Major in English.") Topically, Part III addressed (a) "When the Major Is Declared," (b) "Programs for the Major," (c) "Courses for Seniors," (d) "The Comprehensive Examination," and (e) 
"Honors Programs" (p. v). These headings underscore its bias toward the administration of the English major rather than analysis of its structure or content.

Consequently, Wilcox (1970) presented curriculum particularities about program requirements within the English major, courses for sophomores planning to major in English, and other program requirements such as foreign languages, without treating the abstractions suggested by the particularities. He observed structure through identifying course types (p. 155), but made no generalizations about patterns or forms within the English major curriculum. Further, Wilcox essentially dismissed course sequencing with this conclusion: "There is little agreement ... which courses should be taken when" ( $p$. 161). Reading his report and placing it in the context of the late 1960s, I thought its data could have benefited from more critical interpretation-which he offered later in The Anatomy of Literature (1973).

Without identifying the tripod form of the major by name, Wilcox (1970) compiled statistical tables (numbers 78-80) pointing to the tripod as the basic framework for the English major in the late 1960s. The tripod's dominant leg was literature; its lesser legs, composition and language. Whereas Wilcox did not discuss the major in those terms, the tripodal structure seemed evident when I counted types of courses listed in Table 78 "Requirements for the Major in English (I)" (Wilcox, 1970, p. 159). Of 10 course types listed specifically and not as "Other" or "Electives," 8 represented literature courses, 1 a writing course, and another linguistics (p. 159).

The tripod reiterated its presence in Table 79 which recorded English major requirements according to number of units and levels, such as sophomore or junior credits (p. 160). Table 80 also revealed the pattern of the English major structured as a 
tripod dominated by literature, with 7 of its 10 "Courses for Sophomores Who Plan to Major in English" representing literature courses (Wilcox, 1970, p. 162). Advanced composition and linguistics figured as the lesser, uneven legs of the tripod in this table (pp. 162-163).

Wilcox (1970), I think, should have discussed his findings in the context of the structural tripod, since its continued dominance had been noted previously in the English profession (McEwan, 1992, p. 103). The tripod appeared through his statistical tables, but Wilcox interpreted their details without referring to their evident structure. This made for a slightly out-of-focus picture of the curriculum, as if his panoramic view of the English major panned too quickly and blurred part of the composition.

But this represented a minor blemish, for the Wilcox (1970) survey and report comprised a most impressive work: "a systematic study of the whole of undergraduate English in the United States" (p. ix). Such a comprehensive survey had never been done before, nor has it since. Wilcox and his team compiled the first-and-only complete listing of 4-year English programs in the United States; they identified the form and function of the English department in post-secondary education; made an overview of the English major; and identified major concerns, and even anticipated future concerns for English professionals. Among his three major concerns appeared the inability to define English as a discipline (Wilcox, 1970, pp. viii; 191-194), the same conundrum which today makes prescribing its curriculum unlikely.

No subsequent research on the undergraduate English curriculum has yet equaled the Wilcox (1970) report for comprehensibility. Professional English organizations did relatively little surveying of the curriculum during the 1970 s, not issuing a similar, 
follow-up survey until the 1983-1984 academic year (Harris, 1986; Huber \& Young, 1986).

In 1975, the Modern Language Association (MLA) issued an aggregate of curriculum descriptions selected from 23 schools representative of all Carnegie 4-yeartype colleges and universities (Cowan, 1975, "Introduction"). The editor did little to shape or interpret the 23 reports, which varied considerably in form and organization. Yet Cowan concluded that the tripod model of the English major curriculum remained intact and literature privileged, but rhetoric "[appeared] to [receive] more attention than in the [recent] past" ("Introduction"). Her claim that "[no] value judgments [were] made or intended" sounded ingenuous, as the various writers contextualized their reports with references to the Viet Nam War and to student protest. Metaphorically, this study was a brief, uneven sub-surface effort which anticipated Stewart's (1989) qualitative categorization of the English major types.

During the next decade, the MLA through its Association of Departments of English (ADE) commissioned two surveys concerning post-secondary English. The first, entitled "Report on the 1983-84 Survey of the English Sample" (Huber \& Young, 1986), focused primarily but not solely on the English curriculum; it found British and American literature concerns dominating the administration of the 527 selected English departments sampled. These 527, however, represented departments in relatively large institutions, as schools with full-time-enrollments below 400 were excluded from the sample (Huber \& Young, 1986, p. 40). On that basis, Huber claimed that within the "Typical Undergraduate [English] Department," the "English major [had] remained stable"--that is, dominated by British and American literature (p. 46). 
The second MLA/ADE 1980s survey report addressing curriculum was the "Report on the 1984-85 Survey of the English Sample: General Education Requirements in English and the English Major" (Huber \& Laurence, 1988). Respondents to the section concerning the English major numbered 343 of the " 454 departments and divisions in the permanent sample of English programs" (p. 30); these respondents, like those to the 1983-84 survey, primarily represented large institutions (p. 31). Under "Typical Requirements for the English Major," the researchers observed that "the most prescribed [courses were] British literature survey; American literature survey; Shakespeare; history of the English language, linguistics, or comparative grammar; and literary criticism or theory" (p. 39). Such courses comprised the core, whereas those on the periphery appeared less traditional —ones such as contemporary literature (p. 43).

While these surveys were in process, in 1985 the ADE commissioned an ad hoc committee to study the undergraduate English major curriculum through course descriptions given within college catalogs (Harris, 1986). The committee collected 81 academic catalogs representing 4-year institutions of varying types, including 34 public and 16 private institutions which granted bachelor and master's degrees (p. 26). Harris did not explain the methodology employed by his committee, but I have inferred through Waller's 1986 article that it was close reading. Emphasizing the tentative nature of his report (subtitled "A Progress Report"), Harris wrote that it merely described committee findings (p. 26). Still, he noted that the following "patterns [had] begun to emerge":

1. The basic configuration of the English major [appeared] to have changed only slightly since 1965-68, the period of the Wilcox study. Literature [remained] at the core of the majors. ...

2. [About] $72 \%$ of the listings in the average catalog [were] literature courses; $21 \%$ [were] writing courses ... [and] $6 \%$ [were] courses in linguistics and the history of the language. (pp. 26-27) 
Clearly, the tripod model of the undergraduate English major remained discernible even in the early stages of the ad hoc committee's study, and the major remained "very resistant to fundamental structural change" (K. Lawrence, 1988).

Harris (1986) had anticipated the committee's addressing "larger issues" such as the discovery of "curricular principles" within the catalog introductions and course descriptions, as well as the representation of English itself "as a skills-centered or a subject-centered discipline" (p. 29). His expectations, however, did not materialize as envisioned, due to dissent among committee members over the theoretical basis of the English curriculum (Waller, 1986).

What Harris (1988) did publish subsequent to his 1986 tentative report was entitled "Canonical Variations and the English Curriculum." In it, he gave only $20 \%$ of his text to the "findings" gleaned from the curriculum study, concluding:

The configuration of the English major seems to have remained basically the same for decades, although the beginnings of change - in the texts selected for study and the approaches taken to those texts-may be discerned, especially in elective courses. (p. 11)

Most of Harris's report, which he did not characterize as the work of the ad hoc committee, addressed theoretical battles over the changing nature of the English discipline. These conflicts, he argued, "will have been fought and the ideological casualties buried before the curriculum itself, especially the English major, [reflected]" any significant, resulting change (p. 11).

Qualitative Studies Mark a Transition

Amid such debates, Stewart (1989) published his milestone qualitative study titled, "What Is an English Major, and What Should It Be?"-a title pointedly reflecting 
the 1987 English coalition (p. 1, above). Published by the National Council of Teachers of English (NCTE), his work presented the first-ever categorization of English majors. Having studied English curricula printed in the academic catalogs of 194 selected public and private 4-year schools, Stewart identified four types of English major programs: (a) the straight literature major, with its emphasis on English/British and American literature $(N=11)$; (b) the more flexible program of literary studies, with major courses in creative writing, linguistics, composition, and rhetoric $(N=107)$; (c) the block-option program, with groups of courses made available in studies other than literature (e.g., in creative writing) $(N=74)$; and (d) other programs, primarily with practical skill emphases $(N=2)$ (pp. 189-191).

Stewart (10989) reported a "fairly simple" methodology (p. 188), and from his explanation I have inferred that it was close reading, for he "examined each school's catalog, noting the number of degree options each English department offered, [recorded] the number of hours in literature, language, and linguistics, creative writing, and composition and rhetoric each permitted, and [singled] out certain courses for further study" (Stewart, 1989, pp. 188-189).

Stewart supplemented his observations with a letter inquiring about enrollments and specific course syllabi; to this, 108 of the 194 departments responded. From those replies, he concluded that "the only completely accurate statement that one can make about the major is that it is in constant flux" $(1989$, p. 189). Working in the pre-internet era, Stewart found it "difficult to get up-to-date information on programs" (p. 189). Thus, his study focused on the printed curricula in college catalogs. 
The significance of Stewart's (1989) study was that it represented the initial, basic classification of undergraduate English major curricula. His work provided the impetus for my own study of the English major among the CCCU-issued curricula. When I inquired about any further, possible information about his methodology, Stewart's widow replied in a letter dated July 19, 2001, that no notes about this particular study were left in his files. Thus, I have incorporated his research with Eisner's education criticism, which also relies on close reading.

Stewart's (1989) article marked a transition time in research on the English curriculum; qualitative studies gave way to case studies during the 1990s, but only after a problematic survey appeared. Two years after Stewart established the categories of the English major, the MLA distributed its second survey of the English major curriculumwhose results appeared 5 years later when Huber (1996) issued her report entitled, "Undergraduate English Programs: Findings from an MLA Survey of the 1991-92 Academic Year." Huber's report has been termed "deceptive" by Morrissey and Fruman (1993); excoriated by Balch and Brasor (2001) for ambiguities; and found faulty by me for its inconsistencies and omissions. The 1991-92 survey, however, did attempt to be more inclusive in its sampling than previous MLA surveys. Included among its 669 selected institutions were 2-year colleges, which comprised (a reported) $20 \%$ of the respondent departments $(N=527)$ (Huber, 1996, p. 35).

Private colleges reportedly had more representation in this MLA survey, comprising $39.3 \%$ of the 526 respondents (a questionable figure) (Huber, 1996, p. 35). Large institutions certainly figured prominently: The mean enrollment (of "full-and part time students in [the] fall 1990 [term]") reportedly numbered 8,808 and its median 5,625 
(Huber, 1996, p. 35). For this 1991-1992 MLA survey, “small institution” by definition meant "2,000 or fewer" (p. 35).

Whereas this survey focused on the curriculum offered rather than the officially issued curriculum as its predecessor had (Huber, 1996, p. 37), the 1991-92 MLA survey did indicate that the tripod structure of English remained influential. From the 327 respondent departments (all presumably having 4-year major programs), Huber reported the following statistics: (a) $31.9 \%$ required genre courses; (b) $30.9 \%$ required singleauthors courses; (c) 40.7\% required pre-1800 literary period courses; (d) $31.8 \%$ required post-1800 literary period courses; (e) $30.6 \%$ required writing courses; and (f) $20.5 \%$ required language, linguistics, and/or rhetoric courses (p. 60).

Therefore, the MLA 1991-92 survey, however faulty, indicated that the English major curriculum reflected the traditional tripod dominated by literature and/or literary courses, though composition, writing, or rhetoric had higher percentages of offered courses than in the 1984-85 survey (Huber, 1996, p. 63). World literature also received higher percentages: $24.7 \%$ of 4-year English departments ( $N=344$ in this instance) required student majors to study world literature compared to the $14.7 \%$ which had required it in the 1984-85 survey $(N=225)$ (Huber, 1996, p. 63). Courses added since that academic year included ethnic, multicultural, and postcolonial literature, women's literature, and cultural studies (p. 63). Literary theory or literary criticism represented a requirement also added by many departments to its English major since that earlier study (p. 66).

Whereas the 1990-91 MLA survey omitted a final, interpretive section to summarize its most significant findings, its results indicated a continued reliance on the 
tripod structure for the English major. However, this generalization had to be qualified by the change in this survey's base-that is, to the curriculum offered rather than the curriculum issued which had served as the basis of the 1983-84 survey (Huber, 1996, $\mathrm{p}$. 37). Thus, for some (political?) reason, the surveys lacked correspondence.

Notably, the MLA did not commission a survey of English curriculum at the beginning of the $21^{\text {st }}$ century. The organization issued instead an informal discussion (Schramm, Mitchell, Stephen, \& Laurence, 2003) among a committee of department chairs, who offered anecdotal evidence and speculation about the state of the undergraduate major curriculum. This discussion did echo an earlier initiative (other than surveying): Early in the 1990s, the MLA awarded grants through a Fund for the Improvement of Post-Secondary Education (FIPSE) to underwrite English curriculum studies and revisions among 30 public and private institutions (Heller, 1992; Schroeder, 1993; Spacks, 1993), as well as to promote discussion of the major. Reports on one-third of these studies later appeared as case studies published in the MLA's ADE Bulletin (discussed immediately below.)

Case Studies Rise and Swell

Case studies have represented the most prevalent mode of research on the undergraduate English curriculum since the late-1980s. The over-arching goal of these case studies was sweeping revision of the undergraduate major. At first, even prior to the MLA-FIPSE studies, this aim appeared negatively, that is, to transform the English major from being one dominated by literature (and historical coverage) to one oriented to interpretive, critical skills. Klein (1983), for example, offered such a negatively stated premise for curricular change at the University of Bowling Green: 
This proposal departed from older historical and critical models by stressing that English is more than a body of information about texts, that it is, indeed, a study and practice of certain powers of language and mind. (Klein, 1983, p. 28)

Despite Klein's negative tone, vague definition, and broad claim to orient the English major to "language experiences," the revised curriculum at Bowling Green still emphasized literature - requiring a minimum of 28 hours of literary studies (pp. 29-30). While Klein's (1983) case study challenged the historical coverage of literature as the means for (a) presenting literature to students or (b) organizing the English major, Waller (1985) absolutely dismissed historical coverage for either purpose (p. 32). Coverage he regarded as "the residue of the intellectual battles of the 1930s through the 1950s--the New Critics versus historical scholars," and its aging model of English he denigrated as “residual" (pp. 32-33). Waller's reports $(1985,1986)$ referred often to his own CarnegieMellon English curriculum revision which he directed—a "retheorizing" of the major through rhetoric (1985, p. 34). The resultant courses, he wrote, focused on '[students'] cognitive processes, [on their] self-consciousness, [as well as on] discourse communities," and the courses "bypassed the old canonical approach to English" (Waller, 1985, p. 7). How should Waller's 1980s role be assessed? More specific than Klein or other case study writers in identifying English as a discipline, in re-conceiving English as a curriculum, and in relegating the historical coverage of literature to the past, Waller articulated a heeded call, unlike Berlin's (1996), to reorganize the English major so it would emphasize cognitive skills and strategies (Strickland, 1994, Para. 18-20).

After Waller and through the 1990s, case studies documenting individual revisions of the undergraduate English major tended to minimize the historic coverage of literature and maximize the cognitive skills, theories, and strategies organization. 
Schroeder (1993) reported that the undergraduate English major curriculum at Ursinus College was no longer based on coverage, but rather on the "consciously directed sampling" of courses (Schroeder, 1993, p. 38). Though the revised curriculum at Ursinus still emphasized literature, curricular approaches to literature differed and writing received greater emphasis (p. 38).

Branca (1994) also reported the eclipsing of historical coverage in the Merrimack College English curriculum by "a more flexible major framework [which allowed] students to concentrate their coursework in various areas of literature and composition" (p. 8). The revised curriculum, she wrote, "[focused] on the relations among readers, writers, and texts and examining these relations in a variety of ways" which Branca termed "interpretive methodologies" (p. 9). The process of revision, she explained, led to faculty discussion about vision and resources—one intention of the MLA-FIPSE initiative (p. 10; Spacks, 1993, p. 3).

Other case studies, both MLA and non-MLA funded, appeared in the $A D E$ Bulletin during the 1990s, including Tackach's (1994) account of rebuilding the (once defunct) English major at Roger Williams University. Mason (1994) wrote of revising the English curriculum at Western Washington University; Long (1994) at Willamette University; and, Murphy and O'Shea (1997) at the State University of New York (SUNY) at Oswego. Collectively, these studies reflected significant change toward a new base for the English major curriculum not given to historical coverage but to critical methodologies and writing.

Thus, the 2000s have seen case studies of revised undergraduate curricula which have emphasized critical theories and critical methodologies within all English studies, 
and especially within literature. Francus (2001) reported that West Virginia University revised its English major to underscore critical methods, critical thinking, writing, and diversity. Weber (2001), at the University of Alabama, stressed revision, which ended the accretion of courses, but emphasized critical methodologies in the study of literature. Moffat (2003) stressed that the revised Dickenson College English major achieved coherence through the use of critical methodologies, particularly with literature.

Then Schwartz (2003) contrasted the former and the revised English major curricula at Montclair State University, showing that the latter emphasized the development of students' "critical thinking abilities" and "appreciation of the values of their own and other cultures as reflected in and challenged by literature and film" (p. 19). Interpretation and writing also figured largely in Montclair's new curriculum, which incorporated contemporary conflicts and controversies of the former English discipline into course work and classroom discussion (p. 19). Thus, the Montclair State English faculty practiced Graff's (1992) maxim to "teach the conflicts" within English-by which Graff meant literature. It should be noted that literature remained the dominant study of the Montclair State English major curriculum. As I observed earlier, as the first decade opened on the $21^{\text {st }}$ century, literature remained foundational in revised English programs, but the traditional structuring of literature according to historical periods appeared diminished.

In sum: Case studies have dominated research on the English curriculum for the past two decades, while surveys of the undergraduate English major have appeared on an irregular basis since the Wilcox (1970) report. Surveys have been conducted and reported, with varying success, by the MLA/ADE during the 1983-84 and 1991-92 
academic years. Qualitative studies have appeared occasionally: with Cowan's (1975) collection of curriculum descriptions; in the $\mathrm{ADE}$ ad hoc committee study of college catalogs (Harris, 1986, 1988; K. Lawrence, 1988; Waller, 1986), and in Stewart's (1989) study of catalogs to classify the English major. Notably, few dissertations have addressed the undergraduate English major curriculum (except in regard to composition and writing, and these appeared to address instruction rather than curriculum).

\section{Peck's Study of Presbyterian College English Programs}

One dissertation, however, directly pertained to this study as it concerned the English department and its undergraduate curriculum among a number of Christian liberal arts schools. During the time Wilcox was collecting his national survey results, Peck (1969) surveyed English programs among United Presbyterian Church colleges as "an outgrowth of [the Wilcox] national study" (pp. 1-2). Both Wilcox and the (then) U. S.

Office of Education encouraged Peck's research (p. 2). Indeed, his study was the first and only one until this current study to address the state of undergraduate English among any Christian liberal arts schools.

Peck's study had a multi-faceted purpose redolent of an administrator's rhetoric, for he intended to survey and analyze the information and opinions of

departmental chairmen on matters of required English courses, English programs for future teachers of English, programs for liberal arts English majors, professional practices, and the general role of the English departments in the forty-five colleges affiliated with [his denomination], and to determine the strengths and weaknesses of each department. (Peck, 1969, p. 3)

Peck's methodology included "[determining] the scope of the curricula and the titles of the courses offered" in the catalog of each college (p. 4). From those catalogs, he then developed a 16-page questionnaire which included a two-page chart listing potential 
course offerings. This chart allowed respondents to indicate what courses were included in their programs, and to add information such as credit hours, requirement status, levels, and scheduled offering. Peck also included, as "Part III: The Major in English," nearly three pages of mostly fill-in-the blank items similar to those Wilcox (1970) had posed about the major in his survey. Forty departments responded to Peck's survey (p. 47).

Following the questionnaire, Peck (1969) made on-site visits to 10 of those 40 departments, discussing questionnaire items (to clarify responses) and talking with faculty and students (p. 5). These visits emphasized "experimental and creative freshman programs and curricular changes ... aimed at making [English programs] more relevant to [students]"' (p. 5).

Of Peck's 16 tables dealing with "The English Major" (pp. 87-109), only 6 dealt specifically with the curriculum. These reported the total number of credits required (p. 95); the maximum number of major courses one could take (p. 96); the foreign language requirement (Peck, 1969, p. 98); the comprehensive examination (p. 99); the oral examination (p. 101); required courses (p. 104); and honors provisions (p. 106). Of these six, four courses reported administrative matters rather than curriculum content; consequently, Peck's analysis of the curriculum remained superficial.

A partial explanation for Peck's (1969) lack of in-depth analysis into the English curriculum lay in his reliance on the Wilcox survey which was conducted at the time of Peck's research. Wilcox (1970), as noted above, revealed in his survey a bias toward administrative concerns over curricular. Peck shared that bent, as evidenced by the criteria he developed for his questionnaire-criteria which he attributed to his literature 
review and to NCTE publications - while he rued the apparent lack of "clear guidelines for the development of the English curriculum" (Peck, 1969, p. 14).

With his questionnaire reflecting the Wilcox survey, Peck's results also paralleled that study: Program diversity characterized the curricula among the 40 responding Presbyterian college English departments (p. 87); nevertheless, the structural tripod appeared common among them and literature courses dominated composition and language. This situation appeared through his table of required courses even though Peck found "little agreement on which courses should be required for [the] major" (p. 104). Seven of the most commonly required courses represented literary studies (p. 104). The tripod framework figured often in his survey; for instance, Table LIX reports on "Percentage of Time the Student [Spends] on Composition, Literature, and Grammar" ( $p$. 124).

Consequently, Peck (1969) found that though English programs varied in their requirements among his denominational colleges, their curricula revealed the tripod structure dominated. Peck's (1969) use of college catalogs to collect course names provided a precedent for my own study of the individual curricula and aggregate English curriculum of the 2000-2001 Council for Christian Colleges and Universities (CCCU).

No other dissertation since Peck's (1969) has addressed the undergraduate English major at denominational or Christian colleges, and few dissertations have addressed the English curriculum per se. Lovejoy (1973) assessed a remedial English program at Western Christian College, using criteria gleaned from several professional organizations. His focus proved so limited, however, that his methodology and findings did not pertain to the English major. Easton (2002) examined the English curricula of two 
Canadian community colleges, but employed post-modernist methodology oriented to deconstructionist literary theory. Thus, I have found few dissertations addressing the nature of the undergraduate English major, and only Peck's (1969) addressing it among Christian liberal arts colleges and universities.

\section{The Contemporary Field of Curriculum and Eisner}

Whereas the preceding section dealt with research on the undergraduate English curriculum, especially for its major, this section concerns the field of curriculum. I enter the discussion around 1970, when the field shifted into a new paradigm from curriculum "development" to "theory," because this change occurred at roughly the same time the discipline of English was first being reconceived of as "English studies" (Elbow, 1990; Graff, 1992). That date also marked the beginnings of Eliot Eisner's national impact on the curriculum field and its research methodologies, including his own, education criticism-the main framework for this study.

In this section I enter the discussion when the terms "curricular theorist" and "Reconceptualists" arose. I then identify and explain the terms, in the context of a rough sketch of the field. I present an overview of their influence, but then focus on Eisner's contribution to the field through cognitive pluralism, qualitative methodology, and especially through educational criticism.

Whatever term one uses in the context of curriculum research, the term undoubtedly has a history, connotations, advocates, and detractors. Certainly, the term "curriculum theory" possesses all these, but as Lincoln (1992) observed, one can use the term to enter into discourse without being a curriculum theorist or committed to that ideology (pp. 79 \& 83). Though Lincoln declared that she was "not a curriculum theorist" 
but a humanist, she credited curriculum theorists for "opening a whole field of inquiry to revolutionary ideas" (pp. $79 \& 84)$.

"Curriculum theory" as an influence represented "the Reconceptualization of the curriculum field from a field preoccupied with curriculum development to a field concerned with understanding curriculum, informed by theory in the arts and humanities, and by social theory," according to its foremost advocates, Pinar et al. (2004, p. 65). The capital " $R$ " meant that its adherents regarded their approach as a movement; thus, they called themselves "Reconceptualists," marking a paradigm shift from curriculum development to understanding curriculum, from a bureaucratic interest in institutional or school curriculum to an intellectual interest in understanding curriculum more broadly, including but not limited to school curriculum (Pinar et al., pp. 63-64).

Reconceptualists advocated restructuring the curriculum field according to the understanding of curriculum rather than according to the development of curriculum. At the university level these Reconceptualists have been identified as "curriculum theorists" (Jackson, 1992, p. 21) rather than "curriculum specialists," for the former concerned themselves mainly with social and political contexts, especially the need for change, whereas the latter dealt mainly with the practical employment of particular curricula (pp. 34-37). Pinar noted, however, that this difference has become less pronounced now than during the early years of the Reconceptualist movement (Pinar et al., 2004, pp. 55-57). Reconceptualists, according to Lincoln (1992), dissented against past influences to invoke a new paradigm for the curriculum field. The scope of their dissent may be suggested through two instances: (a) They regarded Tyler's (1949) rationale as outdated (Eisner, 1992, p. 317; Lincoln, 1992, p. 84), because it lacked political and historical 
contexts (Lincoln, 1992, pp. 82 \& 84; Jackson, 1992, p. 35); and (b) Some

Reconceptualists "[reacted] against the extreme rationality inherent in the scientific

management movement's influence on curriculum studies" (Lincoln, 1992, p. 85).

Eisner framed the Reconceptualist argument in respect to their protestations by the following explanation:

What is missing from American schools, they argue, is a deep respect for personal purpose, lived experience, the life of imagination and those forms of understanding that resist dissection and measurement. What is wrong with [American] schools ... is their industrialized format, their mechanistic attitudes toward students, [and] their indifference to personal experience. (Eisner, 1992, p. 317)

Dissent the Reconceptualists certainly possessed, particularly against "the extreme rationality inherent in the scientific management movement's influence on curriculum"; however, they lacked a full-fledged theory, as well as an agenda for effecting change (Lincoln, 1992, p. 83). Therefore, according to Eisner (1992), Reconceptualism actually represented not a movement but an orientation to curriculum (p. 317).

Eisner began his career in the milieu of Reconceptualist thought, amid "growing skepticism toward the prevailing behavioralistic orientations to curriculum" (Pinar et al., 2004, p. 183). Like the Reconceptualists, "he [assumed] that knowledge is a constructed ... form of experience" and that "perception is framework or theory dependent" (Schwandt, 1994, p. 129). Though Eisner on occasion has called himself a curriculum theorist, his primary "[emphasis falls on] the plurality of knowledge and the unique functions of different cognitive forms"' (Eisner, 1992, p. 318).

Focusing on that branch of cognitive pluralism dealing with knowledge (the other he identified as intelligence), Eisner (1992) argued that one distinctly human "[feature] is the capacity to create and manipulate symbols" through language and other forms of 
representation (p. 317). These symbols and symbol systems, he observed,

are powerful cultural resources played out in mathematics, music, literature, science, dance, and visual arts, indeed in any area of human life in which action or form is used to give expression or to represent experience or intention. (Eisner, 1992, p. 317)

Such multiple means of knowledge have pointed to multiple types of intelligence, and ultimately to multiple ways of learning, evaluating, and researching (p. 318). But should one means of knowledge, such as the (putatively) objective scientific model of knowledge, dominate curriculum and instruction, students lose the ability to develop varying mental skills (Eisner, 1992, p. 318; Flinders \& Eisner, 1994, p. 89).

Eisner's position in the field of curriculum may be represented visually on "the curricular compass," the metaphor employed by Lincoln (1992, p. 85) but used broadly here. If the radiating arm of a compass were aligned (with north at the top) and inscribed within a rectangle representing the curriculum field, the eastern half of the field would represent the humanistic domain, and the western would represent the scientific domain. Standing at due north would be the Reconceptualists, represented by Pinar who (in Lincoln's words) would "[reconceive] the curriculum [field] in [broader and at the same time more humanistic] terms than he believed curriculum theorizing [had] been in the earlier part of the $20^{\text {th }}$ century" (Lincoln, 1992, p. 83). Metaphorically, these Reconceptionalists served as the defining, reference or orientation point for the field of curriculum since the 1970s; other curricularists have defined themselves with or against the Reconceptualist redefinition of the field (p. 83). Hence, the Reconceptualists occupy due north.

At due east within the humanistic domain, at the point marked "aesthetic critics" (Lincoln, 1992, p. 90), stands Eisner (2002), whose stature, productivity, and longevity as 
the leading contemporary curriculum theorist dominates the humanist domain (Pinar et al., 2004, p. 183). Aesthetic critics would "[return] aesthetic education to the central core of school curricula." while promoting the dialogic relationship between teacher and student, thereby "emphasizing . . . that meaning that is derived from the experience of the learner and [from what] the learner constructs" (Lincoln, 1974, p. 90).

At due south would stand the traditionalists, represented by Tyler (1949), whose rationale dominated curriculum thought and practice during the 1950s and 1960s when the scientific model appeared ubiquitous (Lincoln, 1992, pp. 82-83) and "curriculum" was conceived as "curriculum development" (Pinar et al., 2004, p. 15).

At due west would stand the positivists, who would represent "objectivity in scientific (positivistic) inquiry," and whose emphasis would be on "the effects of objectification on human subjects" (Lincoln, 1992, p. 81). Curriculum positions within the scientific domain in this sketch of the curriculum field were beyond the scope of my study; I sketched the field to place Eisner within the humanistic domain.

Therefore, as a curriculum theorist oriented to cognitive pluralism, Eisner (1991, p. 1) has promulgated a humanistic approach to curriculum; specifically, he has advocated an aesthetic approach whose critical methodology reflects his own professional education in the fine arts.

\section{Rationale for Using Eisner's Education Criticism}

Eisner's methodology $(1985,1991)$ provided the primary means for my researching the nature and state of the CCCU undergraduate English major. Three main reasons underlie this rationale for using education criticism: (a) its suitability for work in education and the humanities; (b) its use of close reading, an essential research skill for 
English studies; and (c) its compatibility with Stewart's (1989) work, which prompted this current study. These three reasons complete this final section of the literature review. First, education criticism has proven suitable for research in education and the humanities. Eisner has advocated this methodology through numerous publications, but especially through The Education Imagination $(1979 ; 1985)$, and The Enlightened Eye (1991), in which he fully accounts for the theory and process of education criticism. Challenging the idea that the scientific model represents the sole research methodology, he has shown its limitations especially for work in education and the humanities (Flinders \& Eisner, 1994, pp. 383-386; Walker, 1992, p. 107). Eisner's presuppositions, reiterated in the journal of Research in the Teaching of English, denied the belief "that research is ineluctably scientific in character," but promulgated the idea "that a pluralistic epistemology offers far more promising options for understanding the complexities of education than a view of knowledge defined solely by science" (Flinders \& Eisner, 1994, pp. 383-384).

As Eisner developed education criticism in the vein or ilk of art criticism, he understandably appropriated the metaphor of "the enlightened eye" to describe the process of his methodology. "Perception of the world is influenced," he observed in The Enlightened Eye (1991), "by skill, point of view, focus, language, and framework"; moreover, "the schemata we use themselves structure perception" (p. 46). Of course, perception can be biased and/or faulty, so it must be questioned. To assess the believability of perceptions and findings, Eisner identified three criteria: (a) coherence, (b) consensus, and (c) instrumental utility; all pertained to researching in education and the humanities. 
Their pertinence to education and English studies appeared through Eisner's elucidation of the three terms. Regarding coherence "or the tightness of the argument," his exemplifying questions invoked logic and literature:

Does the story make sense? How have conclusions been supported? To what extent have multiple data sources been used to give credence to the interpretation that has been made? Are the observations congruent with the rest of the study? Are there other credible interpretations? (1991, p. 53)

Concerning consensus or "the condition in which ... readers of a work concur that the findings and/or interpretations reported ... are consistent with their own experience or with the evidence presented," Eisner wrote, "Consensus is, after all, a matter of agreement, ... [and] ultimately a matter of persuasion" (1991, p. 56). Of instrumental utility, defined as the "usefulness" which serves to comprehend, anticipate, map a situation or work, Eisner stated, "The good guide deepens and broadens our experience and helps us understand what we are looking at" (pp. 58-59). His use of such words as "story," "persuasion," "map," and "guide" resound the pluralistic knowledge characteristic of education and the humanities.

The second reason for using Eisner's education criticism lies in his use of close reading, a skill defined as a means to discover the meaning of a text by focusing on the language of the text itself, its rhetoric, syntax, tone and structure" and by "[asking] questions about how the formal aspects of the text—such as word choice, word order, and even line length-may shape meaning" (Edmonds, 1994, p. 95).

Stewart's explanation of his reading of the194 collected curricula fitted this type of reading, although he did not use the term. "I examined each school's catalog," he wrote before listing the specifics he recorded (pp. 188-189). Eisner's detailed attention to qualities of a work (Eisner, 1991, p. 86) coincided with Stewart's (1989) attention to the 
details and qualities of the printed curricula (pp. 188-189). Both wanted to find, describe, and interpret the essence of what they observed.

The third reason for employing Eisner's education criticism lies in its compatibility with Stewart's (1989) categorization of English majors, whose report involved three dimensions basic to Eisner's methodology: description, interpretation, and evaluation. As Stewart grouped and identified major types according to characteristic emphases and structure, he used the fundamental tool (after close reading, noted above) of description. Paraphrasing and applying Eisner's conception of description to Stewart's work, I aver that Stewart enabled English educators to see and understand not only the various categories among the 194 curricula he studied, but also their overarching nature (Eisner, 1991, p. 89; Stewart, 1989, p. 188). Stewart perceptively analyzed the individual curricula and aggregate curriculum "to make sense of [them]"; then he helped his readers to see and understand what he discovered (Eisner, 1991, pp. 89-90).

As close reading attends to the particulars of a text (that is, particulars such as repeated or unusual words, themes, and images) so Eisner's methodology stressed attention to the particulars of a work and the resultant meanings. "What is needed," stated Eisner in The Enlightened Eye (1991), "is interpretation and exegesis-in a word, rationality" (p. 51). Further, he explained, "by rationality I mean the exercise of intelligence in the creation or perception of elements as they relate to the whole in which they participate" (p. 51). Certainly, this explanation reflected Stewart's analysis and categorization of the 194 English major curricula.

Stewart also engaged the interpretative dimension found in education criticism; interpretation, he explained, accounted for the meaning(s) of what he had described 
(Stewart, 1989, p. 192). Further, he "[illuminated] the potential consequences of [what he observed]" (Eisner, 1991, p. 95). Stewart saw that "creative writing courses [were] on the rise, and that practical, theoretical, and historical courses in composition and rhetoric [were] becoming available" (p. 190), but what concerned him was

the effect [that] proliferation of practical writing courses [has on] students' perception of the major ... that work in composition is primarily a matter of skills, not intellectual substance. (p. 194)

This example characterized Stewart's (1989) interpretive commentary given throughout his qualitative study of English curricula.

Stewart also used the evaluative dimension that Eisner regarded as appraising and judging (as opposed to objective measurement), because the domain involves value judgments (1991, pp. 99-101). For instance, Stewart (1989) argued for greater emphasis to be given to both rhetoric and composition studies so that "English [student] majors should be given a full perception of work ... going on in the field" (p. 195). Quoting Scott's earlier definition of rhetoric as "“the science and art of communication in language"' (rather than rhetoric as mere freshman composition), Stewart broadly outlined two major programs designed to give students "a more balanced perception of the current English field" (p. 197).

Doing so, Stewart employed the evaluative tool that Eisner included among the dimensions of education criticism. With this rationale, chapter 2 concludes. Chapter 3 presents the methodology involved in applying those frameworks to the English curricula issued by the 2000-2001 CCCU members. Chapter 4 reports the findings of this study, and chapter 5 offers the significance of those findings, conclusions, and suggestions for further heuristic work. 


\section{CHAPTER III}

\section{METHODOLOGY}

The purpose of this study was to explore the undergraduate English major curricula issued by the 101 members of the 2000-2001 Council for Christian Colleges and Universities (CCCU), to discover the nature and state of that aggregate curriculum, and to discern any evidence of Christian thought it possessed. The previous chapter (a) reviewed the body of literature about the English major curriculum mainly among public, secular schools, and the slight research about it among Christian, liberal arts schools; (b) established the reasons for making an exploratory study of the CCCU individual curricula and aggregate curriculum; and (c) provided a rationale for appropriating Eisner's (1985, 1991) education criticism as the primary framework for this study, a framework which readily subsumed Stewart's (1989) categorization of English majors. This chapter explains how both frameworks were applied to those CCCU curricula.

This chapter explains the steps followed for the current study: (a) classifying the types of English majors found within the population of CCCU curricula; (b) collecting the data, which consisted of the official English curricula published within academic bulletins or catalogs from all CCCU schools; (c) drawing a purposeful sampling from among those major curricula; and (d) applying the two frameworks, Stewart's (1989) categorization—slightly modified for this present study — and Eisner's education criticism, to the data. 


\section{The Population of This Study}

During the 2000-2001 academic year, 101 institutions held full membership in the CCCU, an advocacy organization based in Washington, D.C. (CCCU, 2001, para. “About"). Known previously as the Coalition of Christian Colleges and Universities, the CCCU had changed its name in 1999 but retained its acronym and rearticulated its mission: "To advance the cause of Christ-centered higher education and to help our institutions transform lives by faithfully relating scholarship and service to biblical truth" (CCCU, 2001, para. "History"). The list of institutions holding full membership during 2000-2001 appears in Appendix A.

For full membership in the CCCU that year, institutions met four criteria, two of which pertain directly to curriculum:

1. Primary orientation as a four-year college or university in North America with curriculum rooted in the arts and sciences. U.S. institutions [had to] have full, nonprobationary regional accreditation.

2. A public mission based upon the centrality of Jesus Christ and evidence of [a] framework [showing] how faith [was] integrated with the institution's academic and student life programs. (CCCU, 2001, para.org/about)

For this present study I secured the published academic catalogs/curricula offered by the 101 members, 98 of whom had English majors. After making a close reading and an analysis and categorization of each English curriculum, I decided the total population proved overwhelmingly large to treat beyond classification. So, from the 98 , I took a purposeful sampling of 20 according to these criteria: The major regions of the United States, and the nation of Canada, had to be represented; the spectrum of full-time enrollments (FTE) from nearly 600 to nearly 3,200 had to be covered; and at least nine (of more than 30) denominations and/or religious heritages, as well as inter- or non- 
denominational heritages, had to be included. One sub-criterion was to include Arminian, Calvinist, Anabaptist, and Pentecostal schools.

The population of the purposeful sampling included Bethel College (MN), Colorado Christian College (Co), Dallas Baptist University (TX), Dordt College (IA), Eastern Mennonite University (VA), Evangel University (MO), Gordon College (MA), Goshen College (IN), Houghton College (NY), King College (TN), Lee University (TN), Malone College (OH), Northwest Nazarene University (ID), Oklahoma Christian University (OK), Palm Beach Atlantic College (FL), Redeemer University College (ON, Canada), Seattle Pacific University (WA), Simpson College (CA), Westmont College (CA), and Wheaton College (IL). Regional locations, full-time undergraduate enrollments, and religious heritages appear on Table 1.

\section{Data Collection}

From the 101 full members of the 2000-2001 Council for Christian Colleges and Universities, I obtained (where extant) published English curricula through the following means: (a) mailing request letters to their admissions offices for current copies (dated as nearly to 2001 as possible) of their academic catalogs or bulletins; (b) e-mailing followup requests to those institutions whose publications did not reach me within several weeks after my initial, written request; and (d) printing hard copies of English curricula posted electronically on the web sites of those institutions whose catalogs or bulletins I did not soon receive. (A copy of the initial request letter appears in Appendix B.) Eighty CCCU member schools sent copies of their current catalogs or bulletins; 21 did not, or their copies did not reach me, but I secured electronic copies of those curricula through their respective institutional web sites. 
Table 1

Criteria for Purposeful Sampling of CCCU English Curricula

CCCU Member

State/Prov./

Total Under-

(Catalog Dates)

Region

graduates

Religious Heritage

Bethel College

MN/Midwest

2,721

Baptist General Conference

(2001-2002)

Colorado Christian C.

$\mathrm{CO} /$ West

1,786

Interdenominational

(2001-2002)

Dallas Baptist U.

(2002-2004)

TX/Southwest

3,150

Baptist

Dordt College

IA/Midwest

1,430

Christian Reformed Church

(2001-2002)

Eastern Mennonite

VA/Southeast

1,099

Mennonite Church

(2001-2002)

Evangel U.

MO/Midwest

1,525

Assemblies of God

(2000-2002)

Gordon College

MA/Northeast

1,488

Nondenominational

(2001-2002)

Goshen College

(2001-2003)

IN/Midwest

1,084

Mennonite Church

Houghton College

NY/Middle

1,380

Wesleyan Church

(2001-2002)

Atlantic (East)

King College

TN/South

Presbyterian Church

(2001-2002)

Lee University

(2001-2002)

TN/South

3,155

Church of God

Malone College (2001-2002)

$\mathrm{OH} / \mathrm{Midwest}$

1,949

Evangelical Friends Church

Northwest

Nazarene U.

ID/West

1,114

Church of the Nazarene 
Table 1-Continued.

CCCU Member State/Prov./ Total Under-

(Catalog Dates) Region graduates Religious Heritage

Oklahoma

OK/West

1,701

Church of Christ

Christian U.

(2001-2002)

Palm Beach

FL/Southeast

1,838

Interdenominational

Atlantic College

(2001-2002)

Redeemer

University College

ON (Canada)

605

Christian Reformed Church

(2000-2001)

Seattle Pacific U.

(2001-2002)

Simpson College CA/West

(2001-2002)

WA/Northwest

2,636

Free Methodist Church

${ }^{a}$ Westmont College

(2002-2003)

CA/West

1,323

The Christian and Missionary

Alliance

Interdenominational

Wheaton College

(2001-2002)

e IL/Midwest

2,338

Interdenominational

Note: Data were obtained from Peterson's Christian Colleges \& Universities (2000) and CCCU member academic catalogs or bulletins.

${ }^{\mathrm{a} C}$ Catalog published on member's official web site.

I made printed copies and placed these curricula in individually labeled files. Thus, I

worked with English curricula published in CCCU members' official catalogs and bulletins.

These 101 catalogs and bulletins had differing effective dates: 2 represented the academic year 2000-2001; 11 represented 2-year publications for the academic years 2000-2002; 62 represented 1-year publications for the year 2001-2002; 14 represented 2- 
year publications for the years 2001-2003; 8 represented the year 2002-2003; and 4 represented 2-year editions dated 2002-2004. These 101 provided an aggregate of 98 English undergraduate curricula for this study. Three schools did not offer undergraduate majors in English on their campuses although two accessed English programs through nearby universities.

In the purposeful sampling, 2 publications represented the 2000-2002 academic years; 15 publications represented the 2001-2002 year; 1 represented the 2001-2003 years; 1 represented the 2002-2003 year; and 1 the academic years 2002-2004.

In summary, for this study, the 98 English curricula offered by the 2000-2001 CCCU full-membership institutions provided the collected data for the categorization of English majors, while 20 of those curricula comprised the purposeful sampling.

\section{The Research Questions}

Prompting this study were two related questions I developed during the 1990s while revising college English programs: (a) What was the nature and state of the undergraduate English major curriculum within Christian liberal arts colleges and universities, specifically among the member schools of the 2000-2001 Council of Christian Colleges and Universities? and (b) What evidence of Christian thought or influence appeared among the individual CCCU English major curricula, and so, within the aggregate curriculum? The first question originated in my study of English curricula offered by Bethel College (IN) competitors; their English major programs, like Bethel's, looked suitable for secular schools of comparable sizes. These Christian college English curricula appeared to reflect Graff's (1987) field-coverage model of the undergraduate English curriculum: British and American literature courses-organized by survey, 
period, and major author(s) - dominated a required core; several courses in grammar, linguistics, composition, or creative writing completed it; a few English-related courses in drama or journalism circulated about the core, while a few courses representing more recent studies, such as minority literatures and women's studies, orbited in periphery.

I also perceived through revising curriculum at Bethel College that English curricula among such Christian liberal arts schools seemed to show slight evidence of Christian thought. What did appear was the occasional course given to C. S. Lewis, or to Lewis and Tolkien, or to the Inklings, and sometimes a course devoted to Milton. This dearth disturbed me. I supposed that both (a) the demise of English conceived paradigmatically as a discipline and (b) the rise of "English studies" as a somewhat indeterminate field called for greater, more overt evidence of Christian influence on the Christian college English curriculum. Wondering if my perception would prove accurate through a formal study, I framed the second question: What evidence of Christian thought or influence appeared among the individual CCCU English major curricula, and so, within the aggregate curriculum?

Question 1 provoked further questions, all reflecting the usual concerns of curricular analysis; these I termed concomitant questions and lettered them "a" to "g." Question 2, the impetus for this present study, dealt with unknown territory; thus, I did not try to frame any concomitant questions, but left this second question open-ended. Both research questions, as well as the concomitant questions to the first, are as follows:

Research question 1: What was the nature and state of the undergraduate English major curriculum within Christian liberal arts colleges and universities, specifically 
among the member schools of the 2000-2001 Council for Christian Colleges and Universities?

Concomitant question 1a: How did the content of these individual curricula and their aggregate curriculum correspond to Stewart's Modified Categories of English majors?

Concomitant question 1b: What claims appeared among these CCCU English curricula, and did any claim(s) dominate? What assumptions were discernible about the purpose(s) and role(s) of the English major curriculum? What themes (if any) were evident?

Concomitant question 1c: What goals, aims, and objectives (if any) appeared? How were they articulated? What orientations (if any) did they suggest?

Concomitant question 1d: How were the curricula organized, and how was the aggregate curriculum structured? What vestiges (if any) of earlier structures remained?

Concomitant question 1e: What content appeared in the CCCU curricula and its aggregate English major curriculum? Which categories (if any) received emphasis, and which little or no attention? What courses were included?

Concomitant question 1f: What patterns appeared within the content of these CCCU English curricula?

Concomitant question 1g: What curricular strengths and weaknesses, as well as emphases and slights, appeared among the individual curricula and the CCCU aggregate English curriculum?

Research question 2: What evidence of Christian thought appeared among the individual CCCU English major curricula, and so, within the aggregate curriculum? 


\section{Main Framework for the Data Analysis}

Eisner's $(1985,1991)$ education criticism, based on his own education in the arts, served as the primary framework for this present study, which was prompted by Stewart's (1989) classification of undergraduate English major types. As Stewart's categorization process did not offer an encompassing framework, I chose Eisner's education criticism for this study; its use of close reading allowed Eisner's framework to subsume Stewart's.

Figure 1 represents a visual interpretation of Eisner's methodology used for this study. Entitled "Eisner's Four Dimensions of Education Criticism," this illustration presents the principle metaphor of his approach-the "enlightened eye," meaning the education connoisseur acting in the role of critic to educate a particular public needing expert interpretation and evaluation of a work under study (Eisner, 1991, pp. 63-72). In Figure 1 this person sits (at the lower left) looking ultimately at a work (drawn at the upper right corner) through dimensions of his or her enlightened perception. In the illustration, Eisner's four dimensions appear metaphorically as a prism - which I have chosen as a four-in-one figure appropriate to process by which the "enlightened-eye connoisseur" regards the object studied.

Writing of those dimensions in The Enlightened Eye (1991), Eisner warned that in identifying and discussing each separately he "[did] not prescribe a sequence" for their order; further, he added, they should be regarded "as tools with which to work, and not as rules to follow" (pp. 88-89). The first tool or dimension in his education criticism constituted description, whose purpose, he wrote in The Education Imagination (1985), was "to identify and characterize, portray or render in language the relevant qualities of educational life" (Eisner, 1985, p. 230). For this study, description proposed to convey 
EISNER'S FOUR DIMENSIONS OF EDUCATIONAL CRITICISM HOW THE CRINC'S ENUSHTENED EYE GES A WORK AND ITS QUAUTES

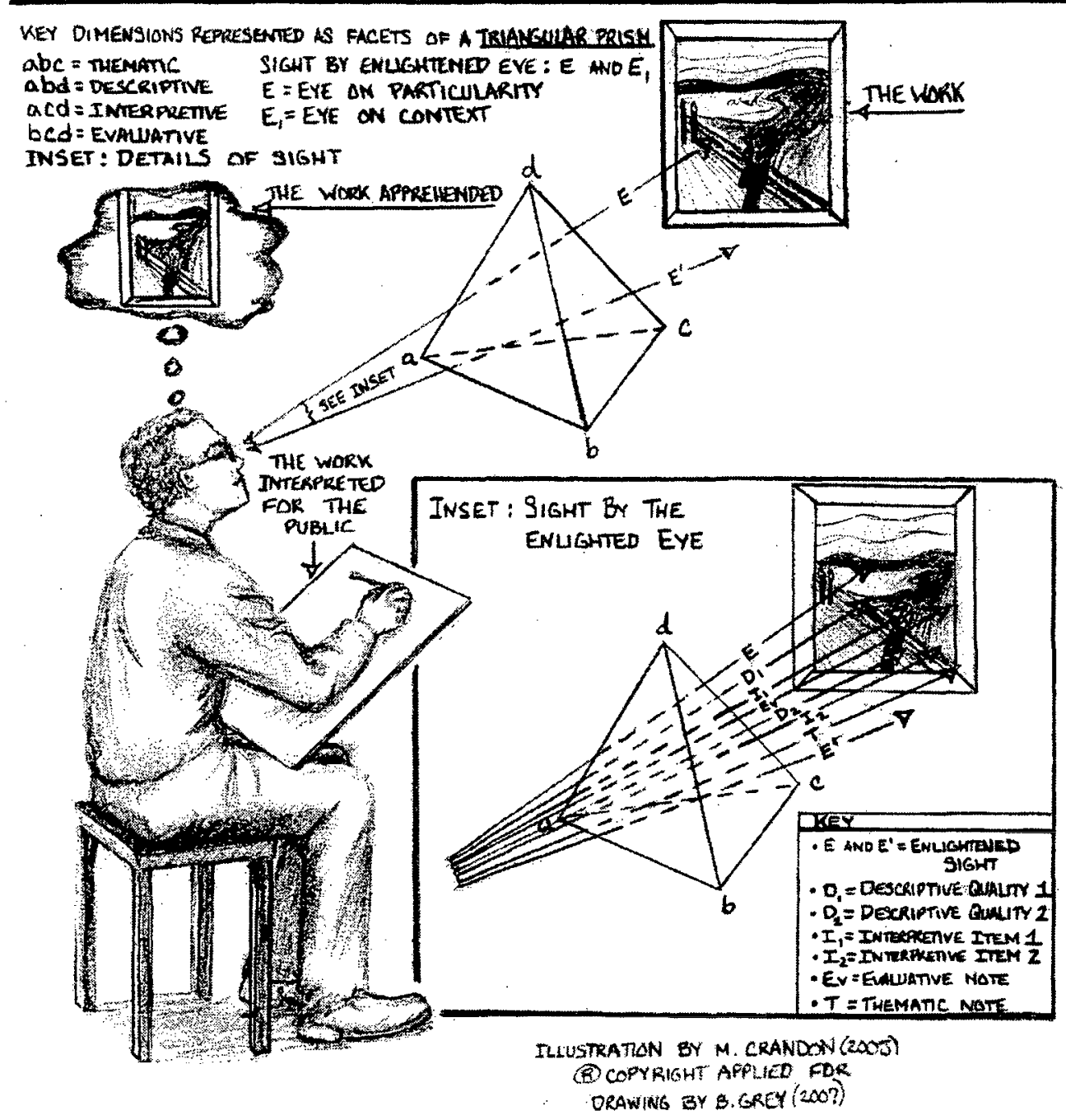

Figure 1. Eisner's four dimensions of education criticism. 
the "relevant qualities" of the CCCU individual curricula and aggregate curriculum. In his later work, The Enlightened Eye (1991), Eisner explained, "Description enables readers to visualize what a place or process is like. It should help them 'see' and ... understand" (p. 89). Further, he added, description "should also enable [them] to participate vicariously in the events [or work] described" (p. 89). The aim of description, he insisted, was "epistemic"; that is, "to help the reader [to] know" (p. 90). He added that visuals and emotions serve as "[sources] of knowing," yet the connoisseur-turned-critic "always tells an incomplete story" or writes it, as no one can convey or re-present wholly the work itself (pp. 89-90).

The second dimension or tool of education criticism constituted interpretation, which Eisner "regarded as accounting for" what description gave "an account of" (1991, p. 95). The emphasis of interpretation, he explained, fell on meaning, and the focus in interpretation sharpened perception of a work's major features (1985, p. 233). In his 1991 explanation of this dimension, he wrote that "To interpret is to place in context, to unwrap, to explicate," and it "focuses on the why or how" (pp. 97-98). He warned the education connoisseur however that though "knowing what to look for makes the search more efficient," it also "can make [him or her] less likely to see things that were not a part of [his or her] expectations" (1991, p. 98).

The third tool or dimension of Eisner's education criticism constituted evaluation, roughly equated with appraisal but absolutely essential to the process (1985, pp. 235236). In his 1991 work, Eisner called evaluation "the task of determining the educational value" of a piece or an event, and he added "there can be no evaluation without value judgments" (p. 100). Earlier, in regard to evaluation, he observed that the critic's own 
value judgments make the evaluative process complicated and complex, but they help "provide the grounds for the value choices made" (Eisner, 1985, pp. 236-237). He advised the critic also to "[recognize] that others might disagree with those choices" (p. 236).

The fourth tool or dimension represented a new development in Eisner's education criticism as he presented it in The Enlightened Eye (1991). "The formulation of themes" he termed "thematics," meaning "the [identification] of recurring messages that pervade" the work or event studied (p. 104). "Themes are [its] dominant features," he wrote, and explained that "in a sense, a theme is like a pervasive quality" (1991, p. 104). Another image he used to define this tool was "distillation": "themes are distillations of what has been encountered" (p. 104).

These tools work interdependently. At once, the connoisseur describes, interprets, evaluates, and beholds the thematic qualities of that work; then, to articulate his or her critical evaluation of that piece, the connoisseur uses language, and perhaps visuals such as this drawing, to re-present the work to others. The re-presenting aspect appears in Figure 1 through three steps: (a) the convergences of the four dimensions into the senses, that is, the eyes of the connoisseur (where the bracket at E and E' connects the work's particularities and its wholeness); (b) the process of articulating in his or her mind what the connoisseur perceives; and, (c) the actual writing or speaking of those perceptions through a critical piece (shown on the easel).

The education connoisseur, like the art connoisseur suggested by Eisner in The Enlightened Eye (1991), conveys a highly knowledgeable, intelligent appraisal of the work studied and does so articulately with the aim of involving his or her audience and 
enhancing their understanding of it. Other arts-based similes for the education connoisseur were an orchestra conductor and an oral interpreter of poetry, both images Eisner employed in "What Can Education Learn from the Arts About the Practice of Education?" (2002).

Eisner's four dimensions or tools of education criticism provided the procedural steps for this present study: (a) Description of the individual curricula and the aggregate CCCU English major curricula; (b) Interpretation of the aggregate CCCU English major curriculum; (c) Evaluation of that aggregate curriculum; and (d) Thematic analysis of that curriculum.

The first three tools proved useful to address the research question about the nature and state of the $\mathrm{CCCU}$ individual curricula and aggregate curriculum; the last particularly addressed the second research question concerning evidence of Christian thought within the aggregate curriculum.

\section{Applying the Main Framework: Description}

Description of the 98 individual English major curricula represented the first step in my research process. Eisner's framework called for a description of each based on a close reading of its text. Since Stewart (1989) had made close readings of 194 English major curricula (of non-CCCU schools) to establish their types or categories, I used his method for the CCCU English curricula. Stewart determined the type of each program according to the number and nature of its course listings. He wrote:

I examined each school's catalog, noting the number of degree options each English department offered, recording the number of hours in literature, language and linguistics, creative writing, and composition and rhetoric each permitted, and singling out certain courses about which I wanted to learn more. (Stewart, 1989, p. 189) 
From these 194 bulletins and catalogs, Stewart (1989) identified four categories of undergraduate English major programs (my emphasis), a term he used interchangeably with "curricula." These were the (a) straight literature program, with emphasis on British and American literature $(N=11)$; (b) the more flexible program of literary studies, with major courses in creative writing, linguistics, composition, and rhetoric $(N=107)$; (c) the block-options program with blocks of courses available in areas other than straight literature, for example, in creative writing, rhetoric, and/or composition $(N=74)$; and (d) other programs, primarily with practical skill emphases $(N=4)$. (N.B. Stewart's use of the word "straight" in 1989 did not carry any sexual reference, and should not be regarded in contrast to "queer studies.")

Wanting further detail about his methodology, I wrote to Stewart's widow in April 2001 to see whether he had left any notes on his 1989 study. She replied that no such evidence appeared among his papers. So, I then developed my own method of recording what I observed in my initial description and analysis of each CCCU English curriculum. This I called the "Close Reading Analysis of English Major Curriculum Card," subtitled the "First Look Card" (shown in Figures 2 and 3).

On each "First Look" file card, I recorded essential information including the name of the CCCU school, academic catalog year, location of the English major (whether in a department or division, etc.), number of major hours at the 200(0) level and above, and other related data such as foreign language requirements. I also recorded any evidence of Christian thought or influence apparent in each published, official English curriculum. For instance, on the North Greenville College card, I recorded the titles and numbers of three courses involving Christianity and literature. For another instance, I 
FIRST LOOK CARD (FOR)

SCHOOL: C U DATE:

LOCATION OF ENGLISH MAJOR: Dept./Div./Other

No. of Major Hours 200(0) \& Above:

Ratio of Courses:

\section{LITERATURE $=$} ENGLISH

No. of Minor Hours 200(0) \& Above:

Foreign/Modern Lang. Requirement:

Stewart's Modified Category:

\section{Comment:}

Figure 2. Descriptive dimension of curricular analysis: "First Look" card (Side 1). 
FIRST LOOK CARD FOR C/U SIDE 2

English Ed. Major Hours:

Other Related Majors:

* Composition

* Rhetoric

* Journalism

* TESOL/variant

* Linguistics

* Writing

* Literature

* Other:

English Minor Hours:

Other Related Minors:

* Composition

* Rhetoric

* Journalism

* TESOL/variant

* Linguistics

* Writing

* Literature

* Other:

* English Ed.

\section{ENGLISH MAJOR:}

NOTABLE:

STRENGTHS:

WEAKNESSES:

EVIDENCE OF CHRISTIAN THOUGHT:

COMMENT:

Figure 3. Descriptive dimension of curricular analysis: "First Look" card (Side 2). 
noted that Lee University had an idealistic-sounding introduction to its curriculum (with phrases such as "Christian perspective"), yet its objectives lacked specific support for such claims.

On the reverse side of this card, I recorded hours required for the English minor and the English Education major. I check-listed any other majors related to the English curricula. Finally, I recorded the curricular strengths and weaknesses I observed during my initial reading/analysis of each English major program. These comments ranged from the perfunctory observation, such as "No minority literature unless it appears under 'Special Topics' at the 400 level' (for Lee University), to the evaluative remark, such as "A strong mix of intellectual and practical courses, but is its writing program overextended [with] only 2 full-time writing professors but 9 full-time English professors ...?" (for Abilene Christian University).

The most significant information recorded on the "First Look" cards developed from Stewart's (1989) research. The CCCU English major programs did reflect the four types which he identified, but they required greater differentiation; that is, they wanted more specific categorizations. Thus, I modified Stewart's paradigm by adding two categories: between his first two categories of "Straight Literature" and "More Flexible" English majors, I added one termed "Primarily Literature," and after his last category I added “Other, Miscellaneous." "Primarily Literature” English majors also emphasized Britain and American literature, also included world literature (to a limited degree), but through elective courses gave some attention to minority literatures, especially African American literature, to creative writing courses, and to a few other electives such as journalism. The "Other, Miscellaneous" category provided for unusual curricula. 
Using Stewart's idea of classifying English majors according to the dominance of literature (or, where appropriate, another emphasis such as writing or rhetoric), I decided to use percentages to assign curricula to their appropriate categories. Since Stewart had determined his paradigm according to the number of literature courses listed in a curriculum, I refined his approach by making a simple ratio of the number of literature courses listed compared to the total number of courses listed. For example, the 20012002 English major at Colorado Christian University offered 13 literature courses within its list of 17 English courses; this created a ratio of .7646 ratio or $76.46 \%$. That figure pointed the English curriculum at Colorado Christian toward the "Straight Literature" category; its lack of other related non-literary courses, such as journalism or English-asa-Second-Language, confirmed that the Colorado Christian curriculum belonged to the "Straight Literature" category.

Having calculated many such ratios earlier in a preliminary, unpublished study of English curricula, I assigned the following percentages to create what I then termed "Stewart's Modified Categories of English Major Types": Type 1-Straight Literature (75\% and higher); Type 1.5-Primarily Literature (65\% to 74\%); Type 2-More Flexible (approximately up to 64\% literature courses); Type 3.0-Block option (structurally determined; percentages varied); Type 4.0-Other; with practical emphasis (percentages varied); and Type 4.5-Other, with miscellaneous programs (percentage varied). Types 3.0, 4.0, and 4.5 were defined by their form, structure, or other feature. Thus, I retained Stewart's approach but modified his categories to provide more specific results.

As my categorization of English curricula progressed, I added descriptive notes to the First Look cards: (a) a white flag labeled WTG MAJ for writing major; (b) a green 
flag labeled TESOL MAJOR; (c) a color-coded rectangle for the Stewart category; (d) a green triangle for a student-friendly catalog or bulletin; and (e) a red triangle for a student-unfriendly catalog or bulletin. As these descriptive notes became more numerous, I revisited previously analyzed curricula to update their cards with pertinent notes.

When I had completed First Look cards for the 98 undergraduate English major curricula issued by the $101 \mathrm{CCCU}$ schools, I then designed three additional cards to help me describe and analyze a number of selected curricula more concertedly. These included the (a) Claims Card shown in Figures 4 and 5 to record any claims, goals, objectives, or other statements which might introduce a curriculum; (b) Content Organization Card shown in Figures 6 and 7 to identify the framework that best represented the structure of a curriculum; and (c) Content Categories and Emphasis Card shown in Figures 8 and 9 to record the most dominant and less emphasized content areas.

Having sketched out this design, I then decided to analyze 10 selected curricula not in the purposeful sampling but which I wanted to analyze in depth. To do so, I selected every 10th bulletin/catalog (with one exception, explained in Figure 6) to analyze any introductory statements among these 2000-2001 CCCU member institutions: Bryan College, TN; Crichton College, TN; Fresno Pacific University, CA; Houston Baptist University, TX; LeTourneau University, TX; Northwest Christian College, OR (which did not offer an English major in its own right, but rather through a nearby university; therefore, I chose the next listed school); Northwest College, WA; Oral 
Claims Card for

C/U SIDE 1

(Name of college or university)

Key: $\mathrm{G}=$ Goal; $\mathrm{OB}=$ Objective; $\mathrm{NI}=$ Not Identified; $\mathrm{I}=$ Indeterminable

CLAIM TYPE According to College/University This Researcher

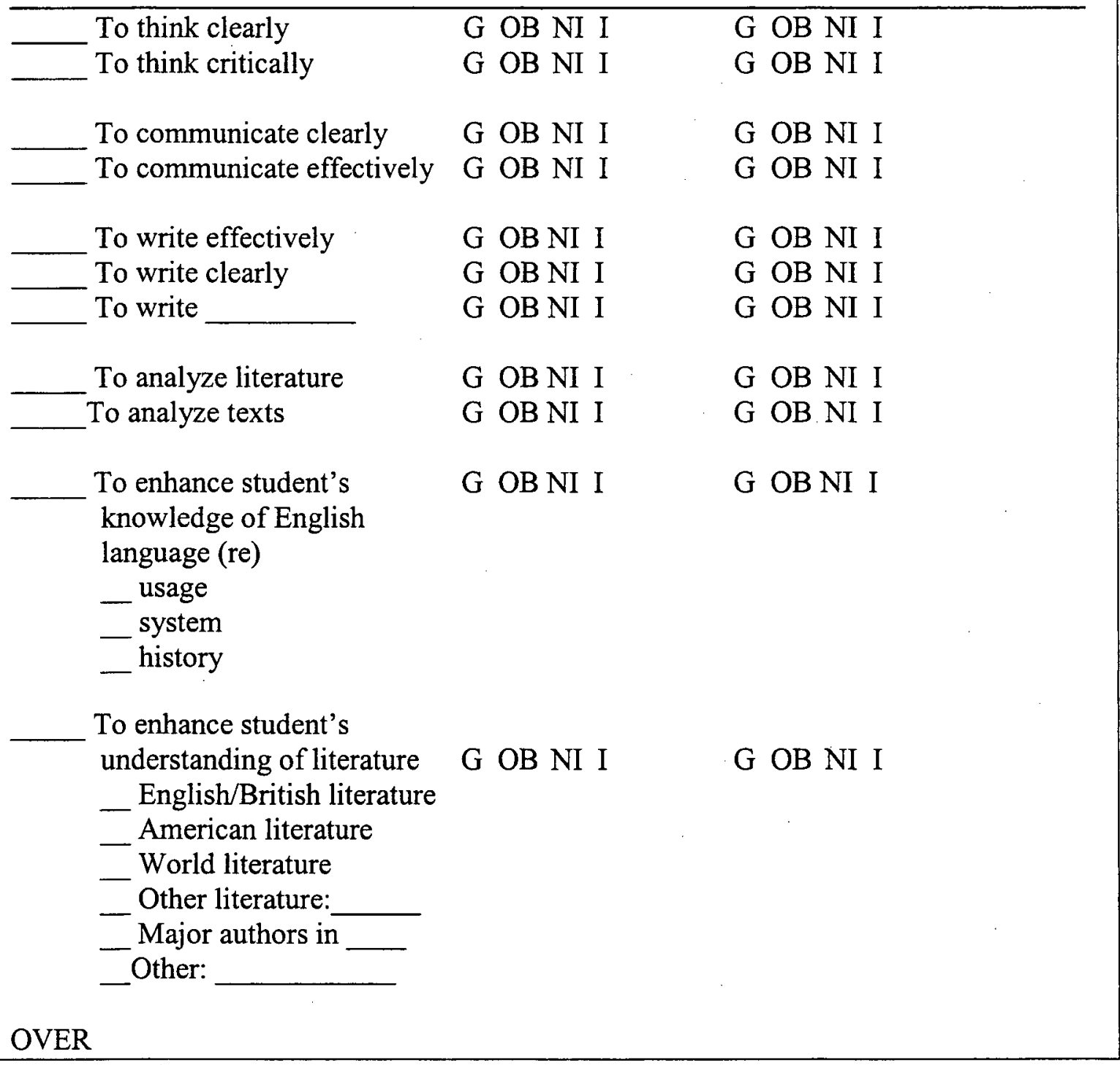

Figure 4. Descriptive dimension of curricular analysis: “Claims” card (Side 1). 
(Name of College or University)

Key: $\mathrm{G}=$ Goal; $\mathrm{OB}=$ Objective; $\mathrm{NI}=$ Not Identified; $\mathrm{I}=$ Indeterminable

CLAIM TYPE According to College/University This Researcher

To prepare student for

G OB NI I

G OB NI I

graduate studies (in)

English

— related disciplines

_other:

To prepare student to teach

English

G OB NI I G OB NI I

at the secondary level

_ as a second language

_other:

To prepare student for career/profession (in)

G OB NI I G OB NI I

_ journalism

media

_writing

_ law

_ ministry/seminary

_other:

To help student integrate

G OB NI I

G OB NI I faith and knowledge

_ faith and learning

_ other:

Other:

G OB NI I

G OB NI I

\section{COMMENTARY}

Figure 5. Descriptive dimension of curricular analysis: "Claims” card (Side 2). 
CONTENT ORGANIZATION CARD FOR C/U SIDE 1

The framework of its undergraduate English major curriculum most closely approximates this structural model/metaphor for English:

Tripod (composite of language, literature, and composition)
Machine (communication skills model)
Growth (organic model, as language for learning)
Text: Process and Content (textual power model)
Literature (moral, values force model)
Core and periphery model (required courses surrounded by
lesser, electives)
Park bench (finite space accommodates new study by
dropping earlier, less-in-demand study)
Other:

Commentary:

(OVER)

Figure 6. Descriptive dimension of curriculum analysis: "Content Organization" card (Side 1). 
CONTENT ORGANIZATION CARD FOR C/U SIDE 2

Originality: Unusual, innovative character, feature, or aspect in the organizational structure

Vestiges: Evidence of earlier structure(s) appear in or through (the)

Introduction

Mission Statement

_ Goals/Aims/Objectives

_Other:

Courses

_ Required

Titles

Core

Electives

— Levels/Numbers

Other:

Non-Course requirements

Structure

Scope and sequence

Other:

Transitions: Evidence of transition(s) appears in or through the Introduction

Mission Statement

— Goals/Aims/Objectives

_Other:

Courses

— Required

Titles

Core

Electives

- Levels/Numbers
- Other:

Compromise: Evidence suggesting compromise appears in or through

\section{Commentary:}

Figure 7. Descriptive dimension of curriculum analysis: "Content Organization" card (Side 2). 


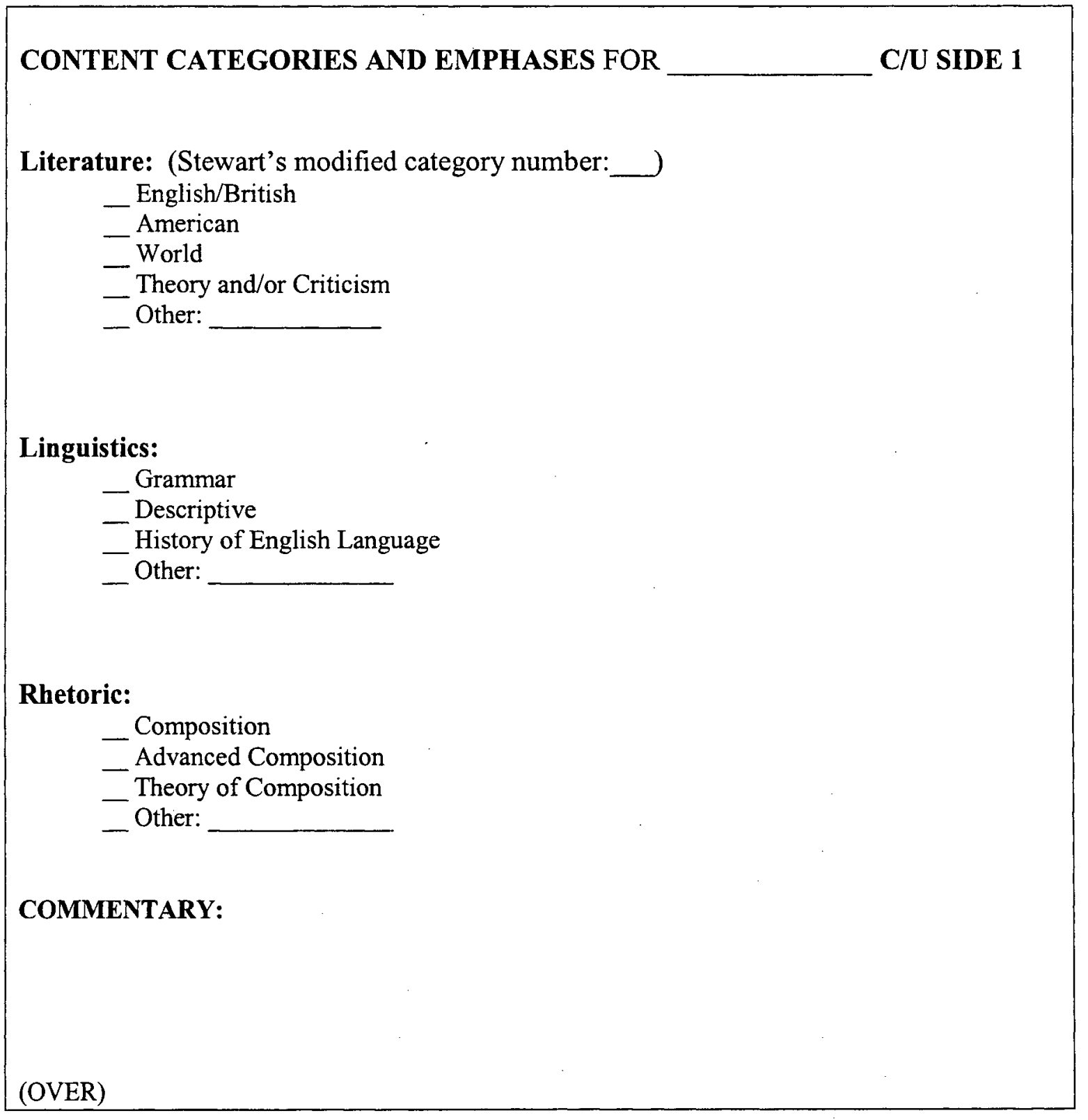

Figure 8. Descriptive dimension of curriculum analysis: "Content Categories and Emphases" card (Side 1). 


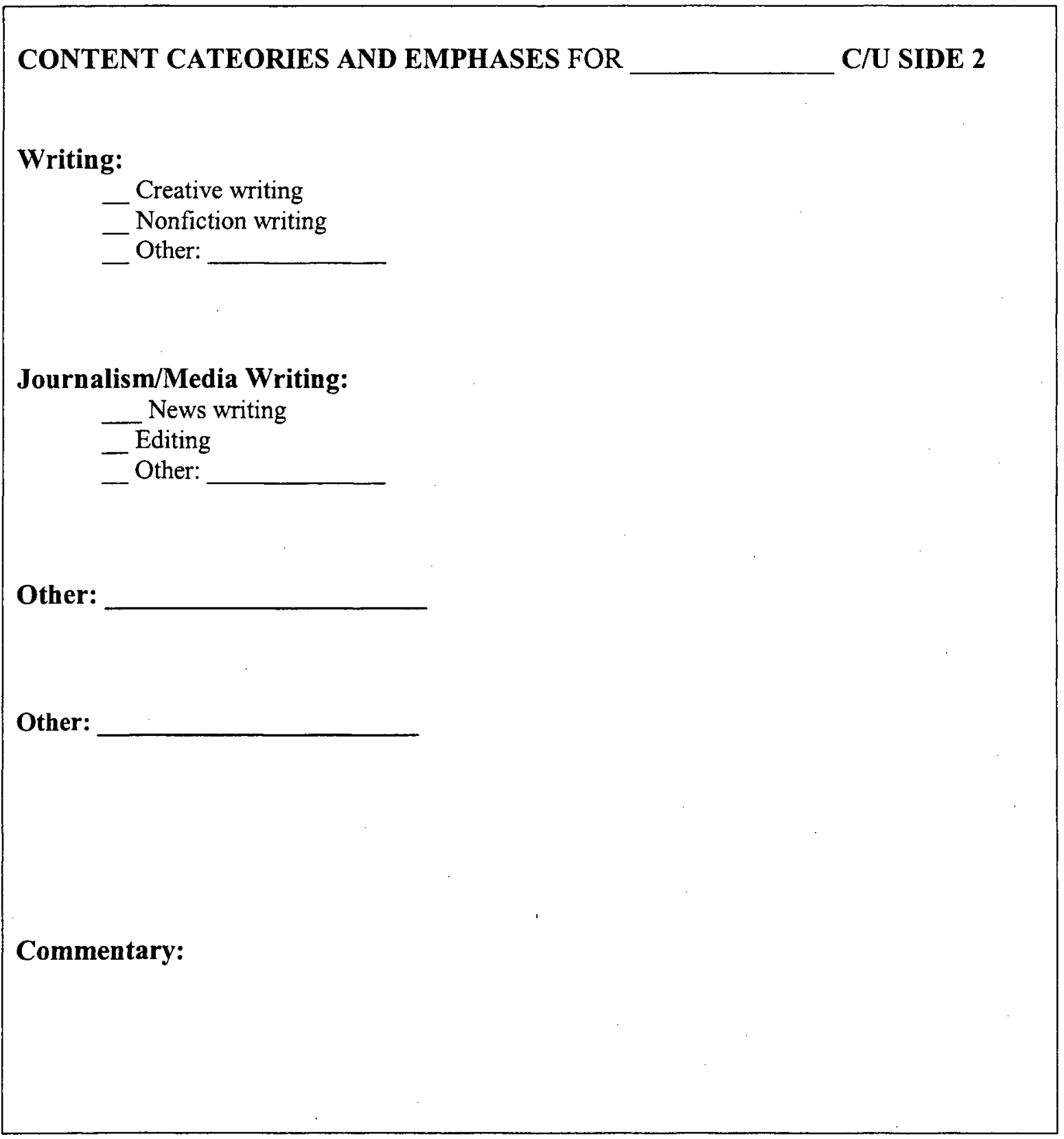

Figure 9. Descriptive dimension of curriculum analysis: "Content Categories and Emphases" card (Side 2). 
Roberts University, OK; Spring Arbor University; MI; Union University, TN; and Williams Baptist College, AR. None of the 10 represented a school whose curriculum I had chosen to analyze in depth later in this study. Having selected them, I then read the introductory statements offered $(N=9)$ and made journal entries describing and analyzing that information and their formats. Journal excerpts appear in Appendix E.

Completing my observations, I then used three different highlighter colors to identify goals appearing often, occasionally, or rarely. The goals cited most often included these (and their close variants): to think critically; to analyze literature; to communicate effectively; and to appreciate literature. The cited goals occasionally included to write effectively, and, to understand through literature what being human means. Rarely did the goal of integrating English and the Christian faith appear ( $N=3$ curricula).

Those broad claims established goals for the students majoring in English, while the following departmental goals also appeared: (a) to prepare students for future careers or professions; (b) to prepare students for graduate studies; (c) to prepare students to teach secondary English; and (d) to promote student faith and learning.

Continuing the descriptive dimension of my research, I designed a Content Organization Card (Figures 6 and 7) to apply to the 20 English curricula I had selected for in-depth study. As this tool had for its background my use of the First Look cards when I made my first close reading of the 98 curricula, I did not select a number of curricula to journal about—as I did before designing the Claims Card. For this, I did not need such an intermediate step. 
Continuing the descriptive work of my study, I designed a third card to apply to the English major curricula I wanted to analyze in depth, the Content Categories. This tool augmented the First Look and Content Organization cards, allowing me to record information specifically that had been reported generally through those other cards. Again, I did not need an intermediate step before designing this tool, as the work I had done in applying the previous two cards prepared me to design the content organizational tool.

These three content cards represented the descriptive tools I applied to the undergraduate English major curricula issued by 20 schools selected from the $98 \mathrm{CCCU}$ members offering the undergraduate English major: Bethel College (MN), Colorado Christian College (CO), Dallas Baptist University (TX), Dordt College (IA), Eastern Mennonite University (VA), Evangel University (MO), Gordon College (MA), Goshen College (IN), Houghton College (NY), King College (TN), Lee University (TN), Malone College (OH); Northwest Nazarene University (D), Oklahoma Christian University (OK), Redeemer University College, ON (CA), Palm Beach Atlantic University (FL), Seattle Pacific University (WA), Simpson College (CA), Westmont College (CA), and Wheaton College (IL).

I chose these $20 \mathrm{CCCU}$ schools primarily to reflect representative characteristics such as geographic location, undergraduate enrollment size, and denominational heritage (as shown in Table 1). Every geographic region of the USA was represented, as well as Canada; enrollments under 600,1,300, 2,000, and over 2,000 were included; and nine different religious heritages were represented. I also chose several midwestern schools considered competitors to my own CCCU college. 
Further, I chose several for some salient characteristic or nature that I had discerned during my initial reading when I completed its First Look card. I then wrote in my journal a complete curricular description and analysis of each English curriculum. These complete analyses, excerpts of which appear in Appendix E, marked the start of my applying the next two dimensions of Eisner's education criticism: interpretation and evaluation.

Applying the Main Framework: Interpretation and Evaluation

The two dimensions of Eisner's education criticism, interpretation and evaluation, were addressed in this study by close reading and journaling. According to Edmonds (1994) in the Encyclopedia of English Studies and Language Arts,

'Close reading' attempts to discover the meaning of a text by focusing on the language of the text itself, its rhetoric, syntax, tone, and structure. [It] differs from [newspaper reading, for example] in that it asks questions about how formal aspects of the text—such as word choice, word order, and even line length - may shape meaning. (p. 194)

Close reading represents a critical method to determine "what is really there," the old catch-phrase used to explain it; though it has its critics, close reading continues to prove the dominate skill underlying literary criticism of all types (p. 195). A leading proponent sees close reading as essential to a reader's understanding and constructing (of) meanings (Berthoff, 1999). Even one of its most vocal critics concedes, "Belief in close reading may be the nearest thing literary scholars have to a shared critical principle" (Rabinowitz, 1994, p. 218).

Certainly, my own close reading of texts proved basic to this study as evidenced by the First Look and Content Analysis cards and by the sample journal entries included in Appendix E. Journaling or journal writing, according to the Encyclopedia of English 
Studies and Language Arts (1994), has represented a central component of composition and language arts curricula since the writing process and writing-to-learn pedagogies of the 1960s and 1970s brought with them increased emphasis (or reemphasis) on invention and the use of language to "think out loud on paper" (p. 682).

For this present study, journaling about an individual curriculum involved such activities as: (a) rereading the curriculum text, (b) annotating it, (c) situating it, which means identifying its location, its religious affiliation or heritage, and its enrollment, (d) analyzing its introductory statement (if given) especially for purpose, function, and/or claims, (e) analyzing its goals and/or objectives (if given), (f) reflecting upon its format, structure, content, and appearance, (g) analyzing the scope and sequence of its courses, as well as course levels, (h) asking questions about it, especially about its structure and content, (i) observing any evidences of Christian thought, especially among the course content, $(\mathrm{j})$ evaluating strengths and weaknesses, as well as other concerns, and (k) offering suggestions for possible changes that might enhance the quality of that curriculum. These 11 steps provided the general pattern for the individual analysis of the 20 selected curricula that comprised the purposeful sampling.

When all 20 curricula had been analyzed through my journaling, I then applied close reading to those journal entries. I color-coded themes or patterns found, especially any that addressed the research questions involved in this study. Specifically, I identified my comments about these questions by two colors: yellow for themes and patterns, and orange for evidence of Christian thought. Having color-coded my journals to determine what evidence I found addressing these two research questions, I then made journal 
entries to reflect on my earlier observations. From these I then generalized the nature of the 20 curricula, as well as their evidence of Christian thought.

Then I compared these generalizations to what the First Look cards revealed. I did this through charting Stewart's Modified Categories of English Curricula for all 98 curricula, and Evidence of Christian thought for the 20 curricula in the purposeful sampling. Asking how this charted information compared to the generalizations I had gleaned from my journals, I then wrote responses to the research questions and the concomitant questions.

Then I organized these responses in the given order of those questions. Thus, I addressed Research Question 1 about the nature of the undergraduate English curriculum within the Christian liberal arts colleges and universities through the following means: (a) close reading, (b) First Look cards, (c) Content Analysis cards, (d) journaling about the 20 selected curricula, that is, analyzing each through a discrete journal entry, (e) colorcoding those journal texts through close reading to answer the two research questions, (f) journaling about the 20 curricula as a selected group, also to address those questions, (g) making observations and generalizations about what I found concerning the questions, (h) comparing my observations and generalizations about these 20 curricula to specific information for all 98 English curricula, and (i) writing responses to each research and each concomitant question. Question 2 concerning the evidence of Christian thought received the same treatment.

Those responses to concomitant questions 1 a to $1 \mathrm{~g}$ arose from the tools used to address both research questions. The First Look cards directly provided data about Stewart's Modified Categories of English Majors (question 1a); about organizational 
structures (question 1d); about presentation patterns (question 1f); as well as strengths, weaknesses, slights, and emphases (question $1 \mathrm{~g}$ ). The Claims Card especially addressed question $1 \mathrm{~b}$ regarding any goals and objectives, and assumptions about the purpose of the English major. The Content Analysis Card and the journal entries addressed all concomitant questions, especially question $1 \mathrm{~g}$ concerning strengths and weaknesses.

Through the application of these tools, I followed Eisner's methodology of education criticism to research the nature of the undergraduate English major among the Christian liberal arts colleges and universities belonging to the 2000-2001 CCCU, and to discover what, if any, evidence of Christian thought appeared among those members' English major curricula. My findings appear next in chapter 4, followed by significances and conclusions in chapter 5 . 


\section{CHAPTER IV}

\section{FINDINGS}

The purpose of this study was to explore and describe the undergraduate English major curricula issued by the members of the 2000-2001 Council for Christian Colleges and Universities (CCCU) to determine the nature and state of their individual curricula and their collective curriculum, and to discern what evidence (if any) of Christian thought appeared within both. Chapter 3 presented the methodology used in this study: Stewart's (1989) Categories of English Majors, modified slightly for this study, as well as Eisner's education criticism as presented in The Educational Imagination (1985) and The Enlightened Eye (1991).

Undergraduate English curricula published within the academic catalogs of the member schools of the 2000-2001 CCCU provided the data for this study, data which I collected by mailing requests to their admissions offices or by accessing their official web sites. I asked for academic catalogs and bulletins dated to or nearly to the year 2001 , and received 80 mailed items fulfilling that request. Twenty-one other curricula I then accessed through institutional web sites, and printed facsimiles of their English curricula from their respective academic catalogs. Thus, I secured all extant CCCU English curricula. The time frame for all catalogs, bulletins, and curricula extended from 2000 to 2004. 
When I had collected the catalogs and located the extant English curricula, I used close reading and index cards to categorize each by type according to a modified version of Stewart's system (1989). I assigned curricula among five content categories: Type 1.0 represented what Stewart called "Straight Literature" (a term then not opposite to "Queer studies"), a curriculum lacking flexibility in its program requirements; Type 1.5, termed "Primarily Literature," one with some flexibility in its program; Type 2.0, termed "More Flexible," a curriculum incorporating several English or English-related studies such as literature, writing, composition, rhetoric, drama, journalism, or film; Type 3.0, termed "Block Option," a curriculum not represented among the 98 studied; Type 4.0, termed "Other, with Practical Emphases," one also not represented among the total studied; and, Type 4.5, termed "Miscellaneous," a curriculum having only two members. Most CCCU English major curricula represented Types 1.0, 1.5, and 2.0 (as shown in Appendix C, "English Major Types"); I found I had to differentiate Types 1.0 and 1.5 by referring to the ratio of literature courses to all English course offerings; a ratio of $75 \%$ literature placed a curriculum in Type 1.0, while a ratio below 75 placed it in Type 1.5.

Although Stewart's (1989) methodology proved useful in determining types of English major curricula, it yielded little information about their nature and state. So, I incorporated Eisner's $(1985,1991)$ education criticism into my research methodology. His approach to qualitative research built upon his early experience in fine art and art criticism; he compared the education critic to the art critic for having highly developed, specialized intelligences which account for their encompassing and perceptive appreciation of educational or artistic works. In The Enlightened Eye (1991), Eisner argued that such critics become connoisseurs as they embrace the further role of 
interpreting a particular piece to the public, so that others may comprehend the work more completely. In Eisner's terms, I intended to appreciate and interpret the aggregate English major curriculum formed by CCCU English curricula.

To make Eisner's methodology tangible for this study, I followed these six steps. First, I developed a First Look Card to record data secured by my close reading of every available CCCU English major curriculum, as well as related programs issued in the 2001 (or proximate) academic catalogs of the full member schools of the 2000-2001 council. The card allowed me to identify the location (e.g., department) of the major; to count the number of major hours at the 200(0) level and above; to determine the ratio of literature courses to the total English offerings; to categorize or type the major according to Stewart's system, which I had modified by adding more categories; to record notable features in the curriculum; to analyze strengths, weaknesses, or concerns; to make comments, and, finally, to record any evidence of Christian influence. For each school having an English major $(N=98)$, I spent at least 2 hours in close reading, making notations about the curriculum and completing its First Look Card.

Second, after many hours of close-reading these curricula, I made a purposeful selection of $20 \mathrm{CCCU}$ English major curricula for in-depth analysis, choosing them according to enrollment, geographic location, and denominational affiliation or heritage. By enrollment, the 20 varied from approximately 600 undergraduates to 3,100 . By geography, they represented six major regions of the United States, and one region of Canada. By denomination, the 20 schools represented nine or more religious heritages. They also reflected various theological orientations, mainly Arminian and Calvinist. 
For the third step, I developed a Claims Card to help analyze and record any claims appearing in the introductory sections of the English curricula. I grouped and listed related claims such as intellectual claims (e.g., to think critically), preparation claims (e.g., to prepare students for graduate studies), career and professional claims (e.g., to prepare students for the law), and integration claims (e.g., the integration of faith and knowledge). I differentiated the types of claims - whether goals, objectives, or indeterminable claims--and further noted how the curriculum identified its claims (if it did), and how I categorized them, for many "goals" were mislabeled as "objectives." Occasionally, I commented upon the given claims.

Fourth, I developed a Content Organization Card to categorize the structural frameworks or approximate models of the 20 selected curricula. Although I provided seven specific categories and allowed for other models, the tripod model and the core and periphery model dominated the 20 curricula. Figures 6 and 7 (shown on pp. 70-71) present the entire Content Organization Card. Beyond determining organization, I also considered the 20 curricula for originality, vestiges, transitions, and compromises. Vestiges arose most often, specifically vestiges of the historical coverage of British and American literature(s).

Fifth, I developed a Content Categories and Emphases Card (Figures 8 and 9) to assist in my description and analysis of the selected curricula. This card served as another check to the First Look Card by requiring my responses to six prompts on the course content: literature, linguistics, rhetoric, writing, journalism/media writing, and "other." Applying this Content Categories and Emphases checklist to the purposeful sampling, I found that for 18 curricula I confirmed my First Look classifications to Stewart's 
Modified Types of English Majors. I changed Gordon College (MA) and Northwest Nazarene University (ID) curricula, which were borderline Type 1.5 Primarily Literature, but proved more characteristic of Type 1.0 Straight Literature programs.

The sixth step in the research methodology called for journaling about each of the 20 selected curricula, which necessitated another close reading of each one. Through journaling, I noted observations about content and presentation as illustrated in seven sample journal entries provided in Appendix E, including those that describe Dallas Baptist University (TX), Gordon College (MA), Goshen College (IN), Houghton College (NY), King College (TN), Seattle Pacific University (WA), and Wheaton College (IL). (Note: In journaling on Houghton and Wheaton, colleges from which I graduated, I wrote about programs that had not been my majors or minors.)

I did not journal alphabetically through the selected 20 curricula; however, I did complete the entries within a 2-week period to keep their content and presentation current in my mind. To some degree I structured my journaling to address my research questions, especially toward the completion of the sampling. Evidence of this can be discerned by comparing the earliest of the seven entries, the piece about Dallas Baptist University curriculum, to the last of the seven on the King College curriculum. Every entry, however, included description of the content provided, omitted, slighted, and/or stressed; description of the structure and organization; commentary on the presentation; commentary on strengths, weaknesses, and/or concerns; and, in response to the two main research questions, observations on the nature and state of the curriculum, as well as any explicit evidence the curriculum gave to Christian influence or thought. (I also arranged such evidence in chart form, as shown in Appendix D.) 


\section{Nature and State of the English Curriculum}

The first of the two research questions which controlled this study asked, "What was the nature and state of the undergraduate English major curriculum within Christian liberal arts colleges and universities, specifically among the member schools of the Council of Christian Colleges and Universities?" To address this question, I fashioned eight subordinate questions lettered $1 \mathrm{a}$ through $1 \mathrm{~h}$; these appear below with their responses, which collectively suggest the answer to the initial research question.

\section{English Major Categories by Content Types}

Research question 1a asked, How did the content of these individual curricula and their aggregate curriculum correspond to Stewart's Modified Categories of English Majors? Stewart's Type 1.0 Straight Literature curriculum dominated the purposeful sampling as well as the total population of CCCU English major curricula. Eleven of the selected 20 or $55 \%$ were Type 1.0 , whereas $46 \%$ of the total population belonged in this category. As 3 of the 101 member schools did not offer English majors, the collected curricula totaled 98 . Thus, 11 schools representing $55 \%$ of the sampling and 47 schools representing $48 \%$ of the population had Type 1.0 Straight Literature English majors. Stewart used the term "Straight Literature" relatively not literally, of course, to identify literature as the essence of the Type 1.0 curriculum; I have modified the term to mean that literature comprised $75 \%$ or more of its English courses between the 200 and 400 levels. A list of all CCCU members and their respective English major types appears in Appendix C. 
Table 2 identifies those curricula among the purposeful sampling for whom literature comprised $75 \%$ or more of their course offerings, qualifying them to be Type 1.0 Straight Literature English majors. Their literature content ranged from $75 \%$ to $100 \%$, but averaged $84 \%$. Together, they represented $55 \%$ of the purposeful sampling.

Stewart's Modified Type 1.5 Primarily Literature English major curricula given on Table 3 numbered 4 and comprised $20 \%$ of the purposeful sampling $(N=20)$. Type 1.5 Primarily Literature English Major curricula included those offered by Dordt College (IA), Evangel University (MO), Malone College (OH), and Oklahoma Christian University (OK). Among the total population, Type 1.5 accounted for 29 of the $98 \mathrm{CCCU}$ English curricula - that is, $30 \%$. To be classified a Type 1.5 Primarily Literature major, a curriculum had to have a ratio from $64 \%$ to $74 \%$ of literature courses compared to the total number of English courses. This figure provided a more definitive means than Stewart originally used to assign literature-dominant curricula to their appropriated categories.

These Type 1.5 Primarily Literature English majors appeared to possess one characteristic feature: a writing program(s) and/or a number of writing courses beyond the stock courses in advanced composition and creative writing. Dordt College stressed writing credits as equally as literature credits within its major; Malone College offered composition as one of four possible related-studies groups beyond the core studies; and Evangel University provided minors in journalism and writing. Oklahoma Christian University, whose major showed eight variations, included an English/Writing major and an English/Writing with Teacher Certification program. Oklahoma Christian University also provided a writing minor that required a junior-level course in technical writing. 
Table 2

Percentage of Literature in Type 1.0 Curricula in CCCU Purposeful Sampling $(N=11)$

CCCU Member Institution

Catalog Years

$\%$ Given to Literature

Colorado Christian University

2001-2002

76

Dallas Baptist University

2002-2004

78

Eastern Mennonite University

2001-2002

83

Gordon College

2001-2002

75

Houghton College $^{\mathrm{a}}$

2001-2002

96

Lee University

2001-2002

80

Northwest Nazarene University

2001-2002

76

Palm Beach Atlantic College

2001-2002

93

Redeemer University College

2000-2002

81

Westmont College

2002-2003

82

Wheaton College

2001-2002

100

Note. Percentages were rounded off to the nearest whole figure.

${ }^{a}$ A writing major is offered by the same department.

${ }^{\mathrm{b}}$ Curriculum was secured from its institutional web site. 
Table 3

Percentage of Literature in Type 1.5 Curricula of CCCU Purposeful Sampling $(N=4)$

CCCU Member Institution

Catalog Years

$\%$ Given to Literature

Dordt College

2001-2002

71

Evangel University

2000-2002

69

Malone College

2001-2002

71

Oklahoma Christian U.

2001-2002

$74-38$

Note. Percentages are rounded off to the nearest whole figure.

${ }^{a}$ Variations exist within the curriculum.

This common characteristic also held true for the population wherein 10 additional Type 1.5 curricula had writing minors or concentrations for a total of 13 of 29 , or nearly $45 \%$ of curricula in the population. In contrast, among Type 1.0 Straight Literature curricula, only 8 of 46 , or $17 \%$ of the population, gave similar weight to writing programs.

Stewart's Type 2.0, More Flexible English major category, had five CCCU curricula among the selected 20 (listed on Table 4). Though these programs merited individual and collective commentary to clarify what Type 2.0 represented for this study, one distinction they shared was to offer fewer literature studies than Types 1.0 and 1.5. For Type 2.0 curricula, the ratio of literature courses to all English courses ranged among the sampling from $39 \%$ to $63 \%$; literature represented an average of only $52 \%$ of their courses. (Note: Percentages were rounded off.) 
Table 4

Percentage of Literature in Type 2.0 Curricula of CCCU Purposeful Sampling $(N=5)$

CCCU Member Institution

Catalog Years

$\%$ Given to Literature

Bethel College (MN)

2001-2002

60

Goshen College (IN)

2001-2002

55

King College (TN)

2001-2002

40

Seattle Pacific U. (WA)

2000-2002

63

Simpson College (CA)

2001-2002

Note. Percentages were rounded off.

The five Type 2.0 More Flexible English curricula among the selected CCCU sample were: (a) Bethel College (MN), (b) Goshen College (IN), (c) King College (TN), (d) Seattle Pacific (WA), and (e) Simpson College (CA). As each program differed, each deserves a brief commentary here to help clarify the major type:

1. Bethel College (MN) - this curriculum had two variants of the English majorEnglish Literature and English Literature and Writing. (A major in writing also existed, and not surprisingly, with a strong literary component.) Both English programs showed strong literary cores, and both allowed many electives (up to 20 in literature). The English Literature and Writing core had only one required course in writing, so that program relied heavily on electives in writing. Though both majors lacked non-Western literatures, each included two courses addressing Christian thought and issues. The presence of the two majors suggested that Bethel College (MN) had accommodated the 
contemporary revival of rhetoric/writing/composition, but may have attempted to subsume it into literature. Nevertheless, for purists demanding an actual writing program, the English department developed a writing major although it lacked several entry-level skill courses as well as a theory offering.

2. Goshen College (IN)-My journal entry (included in Appendix E) for the Goshen program noted that the college's Mennonite values of simplicity, economy, and directness infused its English curriculum. Its structure showed simplicity through a core of literature which required six to seven 300 -level courses. Surrounding that core were nine elective hours, surrounded in turn by six 300 - and 400 -level elective courses in English-related studies such as history or linguistics. Though students had little choice of core courses, they had many choices of electives. The English major thus depended on minors to augment it, especially minors in writing, Teaching English as a Second Language (TESOL), and literature (fortified by international and interdisciplinary literatures)

3. King College (TN)-A journal entry for this action-and-career-oriented curriculum appears in Appendix E, and like the English major at Goshen College, the major at King College began with a required core of literature. This major, too, depended on lesser programs - concentrations rather than minors - to augment its curriculum and to make its program more flexible. Four concentrations had been conjoined to the major, creating an English major with a literature concentration (of 38 semester hours); with a writing concentration (of 38 hours); with a theater concentration (of 44 hours); and, finally, with a communications concentration (of 40 hours). These designed programs reflected the action-and-career emphases stressed in the introduction to the English 
major, and suggested that its designers thought of marketing four different English majors.

4. Seattle Pacific University (WA)-My journal entry (found in Appendix E) for the Seattle Pacific English curriculum applauded its distinct Christian orientation and its decided academic rigor. Its flexibility, the concern here, appeared less in its organization than in its several options to fulfill literature requirements, especially in world and American literatures which included several minority literatures and women's literature. Further flexibility appeared in its electives, especially in the practicum, internship, and study-in-Britain courses.

5. Simpson College (CA)-Flexibility appeared through both the structure and content of the English major curriculum at Simpson College. Structurally, its English major started with a core of eight literature and one (or two) writing courses; that core was followed by a general track of nine semester hours whose options had to address American or British literature (at upper levels) and a writing course. Plus, another upperlevel English course was required for the general track (but with an option in film studies). Finally, a concentration in literature or in writing - consisting of 12 elective hours at the 300 level mainly-completed the Simpson English major.

Beside flexibility, a feature common to these selected five Type 2.0 curricula was a writing program offered within the English department or its division. Bethel College (MN) provided a full major in writing, but writing courses also served its "Major in English Literature"; an example of this mutual service appeared as a senior seminar course entitled "The Writer as Believer." For the other selected Type 2.0 English majors, Goshen College (IN) had a writing minor as one option to augment its major; King 
College offered a writing concentration with its major; Simpson College provided a writing track option to complete its major; and, Seattle Pacific University offered an academically strong and practical writing minor.

Another characteristic shared by these five selected Type 2.0 More Flexible English major curricula was user-friendliness-that is, their apparent ease of usage. Having studied 98 English curricula, I learned to appreciate reader-friendly features such as (a) introductions to orient the reader to the mission, goals, and/or requirements of the curriculum, and four of these five Type 2.0 schools had such introductions (but Goshen did not); (b) clean layouts and designs, preferably with font larger than 8-point, and four of the five used two-column layouts with subheads in boldface lettering (but Bethel used a full-page column layout with boldface and negative subheads); and (c) inclusion of all pertinent information such as lists giving course numbers and titles, and four of the elected Type 2.0 schools did so (but King did so inconsistently).

English majors in Stewart's modified system accounted for nearly all the English major curricula among the 2000-2001 CCCU members. No curriculum represented Stewart's 3.0 Block Option or 4.0 Other, with Practical Emphases types. One school proved difficult to type: George Fox University had no English courses itself and no English major; rather, it offered a "Writing/Literature Major." That title seemed a misnomer, however, as the program required only 9 hours of writing courses, but 21 of literature courses. Had this program offered courses in grammar, linguistics, and composition, it might have been a Type 1.5 or even a 2.0 curriculum. But as I could not determine its literature-to-English-courses-ratio, nor its writing-to-English-courses ratio, I classified the George Fox curriculum as a 4.5 Miscellaneous English major. 
Three institutions among the 2000-2001 CCCU members did not offer English majors: Hope International University (CA), Kentucky Christian College (KY), and Northwest Christian College (OR). The latter had a cooperative program through which students could major in English at the nearby University of Oregon.

In sum: To answer research question 1a about the content of $\mathrm{CCCU}$ individual English curricula classified according to Stewart's Modified Categories of English Majors, I found that Type 1.0 Straight Literature majors dominated-with 48 of 98 curricula (or $49 \%$ ). The Type 1.5 Primarily Literature majors comprised the next largest group with 29 curricula (or, 30\%); whereas Type 2.0 More Flexible English majors had 19 (or, over 19\%). Types 3.0 Block Option did not have any representation, nor did Type 4.0 Other, with Practical Emphases, but the Type 4.5 Other, Miscellaneous English major contained two curricula. Three schools did not offer English majors.

Type 1.0 Straight Literature English major curricula dominated the CCCU member schools, yet nearly one-fifth of the 98 represented the 2.0 More Flexible English major type in which writing figured more significantly than in other types.

\section{Claims Among English Curricula}

Research question $1 \mathrm{~b}$ asked, What claims appeared among these CCCU English curricula, and did any claim(s) dominate? What assumptions were discernible about the purpose(s) and role(s) of the English major curriculum? What themes (if any) were evident?

To address this question, I analyzed claims among the $20 \mathrm{CCCU}$ English curricula in the purposeful sampling (shown on Table 5). What impressed me as I completed the claims cards was the number of curricula lacking introductory claims -8 of 20 . These 
Table 5

Three Most Recurring Introductory Claims Among Sampled CCCU English Curricula $(N=20)$

$\begin{array}{llll}\text { CCCU/Claim Member } & \text { Preparation for } & \text { Preparation for } & \text { Preparation } \\ \text { for (Catalog Years) } & \text { Graduate Studies } & \text { Careers/Professions } & \text { Teaching }\end{array}$

Bethel College (MN)

$\mathrm{x}$

(2001-2002)

Colorado Christian U.

(2001-2002)

Eastern Mennonite U.

(2001-2002)

Evangel University

(2000-2002)

King College

(2001-2002)

Lee University

(2001-2002)

Malone College

(2001-2002)

Seattle Pacific U.

(2001-2002)

Simpson College

(2001-2002)

Westmont College

$(2002-2003)^{\mathrm{a}}$

Wheaton College (IL) (2001-2002)

$\mathrm{X}$

$\mathrm{X}$

$\mathrm{X}$

$\mathbf{X}$

$\mathrm{x}$

$\mathbf{x}$
$\mathrm{X}$

$\mathrm{X}$

$\mathrm{x}$

$\mathrm{x}$

$\mathrm{X}$

$\mathrm{X}$

$\mathrm{X}$

$\mathbf{x}$

$\mathrm{x}$

$\mathrm{X}$

$\mathbf{X}$

$\mathrm{X}$

$\mathrm{X}$

$\mathrm{X}$

$\mathbf{x}$

$\mathbf{x}$

$\mathrm{x}$

${ }^{\mathrm{a}}$ Accessed through institutional official web site. 
included curricula for (a) Dallas Baptist University, (b) Dordt College, (c) Goshen College, (d) Houghton College, (e) Northwest Nazarene University, (f) Oklahoma Christian University, (g) Palm Beach Atlantic University, and (h) Redeemer University College. Notably, the eight represented the three types of majors found among the 98 .

Among the CCCU English curricula which articulated claims, three broad themes concerning the preparatory role of the major recurred: to prepare students for graduate study, for professions and careers, and, specifically, for careers in teaching. Of the nine curricula claiming to prepare students for graduate studies, three indicated those studies might be in English or other disciplines. The claimants included two Type 1.0 Straight Literature English Major, three Type 1.5 Primarily Literature, and three Type 2.0 More Flexible Major curricula. Ten English major curricula claimed overtly, but one implicitly, to prepare students for careers and professions, especially the law $(N=4)$, ministry $(N=$ 4), journalism $(N=3)$, medicine $(N=3)$, and business $(N=3)$, but also publishing, broadcasting, media, and other career areas. Six major curricula claimed to prepare students to teach, including one Type 1.0, three Type 1.5, and two Type 2.0 curricula.

Several claims not directly addressing preparation for future studies or careers appeared among the 20 selected English major curricula. Three Type 2.0 More Flexible curricula claimed to foster the integration of Christian faith and knowledge. One Type 1.0 program called for students "to develop an appreciation of ideas and values" (Northwest Nazarene University Undergraduate Catalog, 2001-2002, p. 113). Another Type 1.0 expected students "to enjoy good literature" (Westmont College Catalog, 2002-2003). No curriculum cited a certain claim which I had noted in the CCCU curricula of the late 1990s-to appreciate life. 
Two recurring assumptions that I observed while analyzing the 20 selected curricula were that (a) the English major had to justify itself as a means to career and professional preparation, and (b) literature seemed to have to relate directly to what students wanted to achieve after undergraduate studies. I also noted two interrelated and recurring themes: (a) English graduates entered the professions and/or careers requiring persuasive thinking (e.g., law, ministry, journalism, and teaching), and (b) they entered service-oriented but not necessarily low-salaried careers such as law, ministry, medicine, and teaching.

Illustrating these assumptions and themes, the introduction to the English major in the Lee University Undergraduate Catalog 2001-2002 asserted that "English . . prepares students for graduate work in the discipline, or careers in research, writing, and editing, and a variety of other occupations" (p. 160). That quotation typically gave greater weight to careers and occupations than to graduate studies, a pattern apparent through Table 5 . There, two of the three most recurring introductory claims among the purposeful sampling related to careers/professions and teaching (which presumes professional status).

\section{Goals, Aims, and Objectives}

Research question 1c asked, What goals, aims, and/or objectives (if any) appeared? How were they articulated? What orientations (if any) did they suggest?

To address this question, I made a composite record of the Claims Card data which I had gleaned from the 20 selected CCCU English curricula. This card recorded not only the claims made, but also the ways these claims were identified by the curricula themselves: as aims, goals, objectives, or simply unidentified, unlabelled statements. 
Further, the Claims Card allowed me to compare how I labeled the same claimswhether goals or objectives, or other statements. In this respect, my thinking reflected my initial training in curriculum studies-the Miller and Sellers' (1986) emphasis on goalsas well as Eisner's (1969) concern for larger concepts than behavioral objectives.

When goals and objectives appeared among the purposeful sampling, they tended to be intellectual rather than social, affective, or spiritual. So, this discussion will focus on academic aims found among the 20 curricula in that sampling. Grouped together and summarized, these goals appear on Table 6 in the infinitive form (e.g., "To think critically"). Reducing them to their kernel ideas allowed me to categorize similar aims, which proved pertinent to "service goals"- those appearing among English courses serving the entire academic community. Freshman composition, for instance, supported all programs by challenging students "to think clearly" and "to communicate effectively." Goals specifically related to the English curricula among the CCCU sampling reflected the traditional paradigm of English defined as literature, language (that is, grammar and linguistics), and composition. Literary-oriented goals dominated, as shown on Table 6; five goals pertained directly to the understanding and analysis of literature. And the literature named sounded redolent of that traditional model: British/English literature, American literature, and world literature. Other literary-related goals of lesser import were mentioned, but did not suggest any pattern.

The lesser "legs" of the old tripod model of English received less attention among the English major intellectual goals (given on Table 6). Language identified three goals, introduced by the infinitive "to enhance"; namely, (a) the student's knowledge of English as a language system, (b) her usage of the English language system, and (c) her 
Table 6

Intellectual Goals Cited and Implied Among Sampled CCCU English Curricula $(N=20)$

Intellectual Goals

Times Cited

Times Implied

\section{Service-related goals}

To think clearly

To think critically

3

2

To communicate clearly

To write effectively

To write clearly

To strengthen writing skills

To write critically/analytically

\section{English major specific goals}

To analyze literature

To analyze texts

To enhance student's knowledge

of English language usage

To enhance student's knowledge of English language system

To enhance student's knowledge of history of the English language

To enhance student's understanding of English/British literature

To enhance student's understanding of world literature

Other literature-related, minor claims 
knowledge of the history of that system. Composition did not receive its due, having been cited explicitly among the service goals but merely implied among the English major curriculum goals.

The term "implied goals" referred to those aims that appeared unidentified as goals themselves, but which suggested broad achievement—primarily intellectual achievement. The Wheaton College English curriculum provided two clear examples: (a) "Students intending to pursue graduate studies are strongly encouraged to elect Modern Literary Theory [434]"; and (b) "Students planning to teach English on the secondary level should refer to certification requirements in the Education Department" (italics in original) (Wheaton College Catalog, 2001-2002, p. 78). A third instance of an implied goal appeared in the Malone College curriculum apart from its identified goals. "English ... majors at Malone College benefit from [classes conducted] in a dialogic and communicative manner" (Malone College Catalog, 2001-2002, p. 87). One of the most encompassing implied goals concluded the opening statement of the Bethel College (MN) English curricula:

Each of these areas [i.e., intellect, affective, aesthetic, moral, creative areas] must be nurtured [for students] to develop as whole persons with lives committed to meaningful work and enriched by the capacity for lifelong learning. (Bethel College 2001-2002 Catalog, 2001, p. 121)

Such evidence of implied goals illustrated how the 20 sampled CCCU English curricula did not clearly articulate all their goals; nor did they clearly differentiate goals from objectives. After reviewing the data by major types for identified versus actual goals, and for identified versus actual objectives, I decided the information did not lend itself to patterns and tables. Other means were needed, especially one given to reflective thought: I turned, as I explained in chapter 3, to journaling. 
To convey here the disparate expressions of the goals, objectives, and other such statements, I have chosen three excerpts from the selected curricula texts plus my journal entries about them. The first excerpt comes from the Dallas Baptist University 2002-2004 Undergraduate Catalog English curriculum whose list of goals began by declaring, "The department will provide English majors and minors, as well as students in foundation courses, with a curriculum [equipping] them to think, read, and write critically" (p. 202).

In my journal entry for Dallas Baptist University, reproduced in Appendix E, I observed this about the excerpted claim (above):

Saying nothing about the nature of English as a discipline, this initial point established the English department and curriculum as service-oriented entities. [Student] readers would hardly have thought of English in terms of 'service' to the university. Would they have been interested? Certainly, the first item under the bold headline 'Goal [sic] of the English Major' did not inform students about the English major itself.

The Dallas Baptist University English goals indicated what the department intended to accomplish for itself, rather than what it wanted its students to achieve.

The second curriculum excerpt appeared immediately under the title "Academic Objectives" for the English major in the Northwest Nazarene University Undergraduate Catalog, 2001-2002: "The English-Education [sic] major offers students an opportunity to experience representative American, British, and world literature, to discover and develop an appreciation of ideas and values, to cultivate critical thinking" (p. 113).

In my journal entry about the Northwest Nazarene University curricula I wrote:

'Academic Objective' serves as a misnomer as the content presents goals; further, the paragraph sounds in its content and tone much like a mission statement [with its sweeping, broad goals].

However critical my journal sounded about this claim, I applauded the Northwest Nazarene University English faculty for articulating their curricular goals. However, I 
also noted that this English curriculum "[neglected] to connect its 'objectives' with its long, rather cluttered listing of major requirements" (Journal). This observation made me realize one need for subsequent research — to study how well curricular goals related to offered courses.

The third curriculum excerpt, which suggested the diversity of expressed goals and objectives, as well as those implied, appeared in the introductory paragraphs to the English curriculum in the Malone College Undergraduate Schools Catalog, 2001-2002:

Surrounded by a Christian atmosphere, a major in English, equips students to lead purposeful and productive lives as educated members [of their communities]. The [department] seeks to define what it is to be human by real and imagined experience; by teaching how to think creatively and critically, using interpretive and analytical abilities; and by examining valuable lessons about the human experience. ... At Malone, the primary goals of the Department of Language and Literature are to enable students to read with insight and understanding, and to write with an awareness of audience, purpose, and context. (p. 87)

In my journal entry (included in Appendix E) about the Malone curriculum, I observed:

[The] initial paragraph of this introduction carries an idealistic tone, while it briefly describes the English curriculum as 'Surrounded by a Christian atmosphere'-an introductory, dependent phrase [modifying] "a major [program] in English" rather than individuals studying English. Can a program be "Surrounded by Christian atmosphere"? This phrase serves as a global, yet barebones descriptor.

Although my journal entry sounded rather wary of the phrase "Surrounded by Christian atmosphere," I nevertheless found the introductory tone upbeat. In summary, the main intellectual claims, goals, and/or objectives of the 20 selected CCCU English major curricula appeared threefold in this order of importance: to think critically, to understand literature, and to communicate effectively. They were expressed in such diverse styles, however, that all I may say about orientations is that most claims reflected the traditional paradigm which defined English as the discipline of literature, composition, and linguistics. 
Organization of the Curricula

Research question 1d asked, How were the curricula organized, and how was the aggregate curriculum structured? What vestiges (if any) of earlier structures remained? What (if any) signs of transition and/or innovation appeared? To address this question, I scanned my journal entries on the 20 selected CCCU English curricula with four differently colored highlighters to color-code organizational structures, vestiges of earlier models, and signs of transition.

First, I coded structural models. Through having written those 20 journals and having recorded (earlier) the First Look cards for all the CCCU English curricula, I knew that two structures dominated: (a) the outdated tripod model of English designed to star literature and cast composition and linguistics in lesser roles, and (b) the core-andperiphery model which preserved much of the traditional canon of British and American literature within a central group of required courses, while allowing newer courses such as world, multicultural, and women's literature and newer emphases such as writing and TESOL to circulate around that core in an expanding periphery. I highlighted the tripodal models in yellow, and the core-and-periphery in pink.

Of course, I watched for evidence of any other structural framework identified by McEwan (1992), particularly for the model he named the "Process and Context: The Text" model, versions of which Berlin (1996) promulgated and Scholes (1998) drewEnglish reconceived as the process and analysis of texts. I did not find evidence of that model or any other model among the 20 curricula, which evidenced the tripod and the core-and-periphery models only. Table 7 records my findings for the 20 selected CCCU curricula. 
Table 7

Curricular Types and Structures Among Sampled CCCU English Curricula $(N=20)$

\begin{tabular}{|c|c|c|c|c|}
\hline $\begin{array}{l}\text { English Major Curricula } \\
\text { Among CCCU } \\
\text { Institutions }\end{array}$ & $\begin{array}{l}\text { Catalog or } \\
\text { Bulletin } \\
\text { Year }\end{array}$ & $\begin{array}{l}\text { Stewart's } \\
\text { Modified } \\
\text { Type }\end{array}$ & $\begin{array}{l}\text { Traditional } \\
\text { Tripod(al) } \\
\text { Structure }\end{array}$ & $\begin{array}{l}\text { Core-and- } \\
\text { Periphery } \\
\text { Structure }\end{array}$ \\
\hline Bethel College (MN) & 2001-2002 & 2.0 & & $\mathrm{x}$ \\
\hline Colorado Christian University & $2001-2002$ & 1.0 & $\mathrm{x}$ & \\
\hline Dallas Baptist University & $2002-2004$ & 1.0 & $\mathrm{x}$ & \\
\hline Dordt College & $2001-2002$ & 1.5 & $\mathrm{x}$ & \\
\hline Eastern Mennonite University & 2001-2002 & 1.0 & $\mathrm{x}$ & \\
\hline Evangel University & $2000-2002$ & 1.5 & $\mathrm{x}$ & \\
\hline Gordon College & 2001-2002 & 1.0 & $\mathrm{x}$ & \\
\hline Goshen College & $2001-2003$ & 2.0 & & $\mathrm{x}$ \\
\hline Houghton College & 2001-2002 & 1.0 & $\mathrm{x}$ & \\
\hline King College & $2001-2002$ & 2.0 & & $\mathrm{x}$ \\
\hline Lee University & 2001-2002 & 1.0 & & $\mathrm{x}$ \\
\hline Malone College & 2001-2002 & 1.5 & & $\mathrm{x}$ \\
\hline Northwest Nazarene University & 2001-2002 & 1.0 & $\mathrm{x}$ & \\
\hline Oklahoma Christian University & $2001-2002$ & 1.5 & & $\mathrm{x}$ \\
\hline Palm Beach Atlantic University & 2001-2002 & 1.0 & & $\mathbf{x}$ \\
\hline Redeemer University College & $2000-2002$ & 1.0 & $\mathrm{x}$ & \\
\hline Seattle Pacific University & $2000-2002$ & 2.0 & & $\mathrm{x}$ \\
\hline Simpson College & $2001-2002$ & 2.0 & & $\mathrm{x}$ \\
\hline Westmont College & $2002-2003$ & 1.0 & & $\mathrm{x}$ \\
\hline Wheaton College (II) & $2001-2002$ & 1.0 & & $\mathrm{x}$ \\
\hline
\end{tabular}


Next I scanned my journal entries for vestiges of any previous model, but saw only the pervasive English-as-the-field-coverage-of-literature model (Graff, 1987, 1992), a model concomitant with the traditional tripod. The term "field coverage" referred to the division of British and American literature into time periods such as the Renaissance and the Victorian eras. Known also as historical coverage, field coverage often featured major author courses-primarily Chaucer, Shakespeare, and Milton-and major movements such as Romanticism or Modernism. Such period, author, and movement courses were taught or "covered" by faculty specialists (at least at larger universities). Evidence of such field coverage appeared among the 20 curricula through courses such as "British Literature to $1800 . "$

An example of a curriculum preserving vestiges of the field coverage of literature could be seen in the Seattle Pacific University English program whose "Core Courses" included (a) "English Literature: Beginnings through Milton,” and (b) “English Literature: Restoration through Victoria." The King College English major provided another such example. Its "Core Requirements" called for the completion of one course in "British Literature before 1800" and another in "British Literature after 1800." Options to meet these requirements included other courses redolent of field coverage: "Shakespeare," "Milton," and "British Romanticism and the Nineteenth Century."

Vestiges of the field coverage of literature model proved pervasive among the 20 English curricula in the purposeful sampling, especially among those representing Stewart's Modified Types 1.0 Straight Literature and 1.5 Primarily Literature majors. Vestiges also appeared among the Type 2.0 More Flexible English curricula. Table 8 


\section{Table 8}

Vestiges of Field Coverage in Selected Types and Structures of CCCU English Curricula

$\begin{array}{llll}\text { Stewart's } & \text { Dominant } & \text { CCCU School } & \text { Vestiges of } \\ \text { Modified Type } & \text { Model or } & \text { (Academic Catalog } & \text { Field Coverage: } \\ & \text { Structure } & \text { Years) } & \text { Course Title/Levels }\end{array}$

Type 1.0

Straight Literature

Type 1.0

Straight Literature

Type 1.5

Primarily Literature

Type 1.5

Primarily Literature

Core-andperiphery

Malone College (2001-2002)

Core-and- Lee University

periphery

(2001-2002)

Dordt College

(2001-2002)

Tripod

Type 2.0

More Flexible

Type 2.0

More Flexible
Core-andperiphery
Gordon College

(2001-2002)
Requirement Options:

Victorian Literature 200

Early American Lit. 200

Milton \& the $17^{\text {th }}$ Century 300

Classicism \& Romanticism 300

Twentieth-Century British Literature 300

Modern American Literature 300

Contemporary American

Literature 300

Requirements:

English Literature 300

American Literature 300

Shakespeare 400

Electives:

Milton 300

Restoration \& $18^{\text {th }}$ Cent. Lit 400

Victorian Literature 400

Early Modern Literature 400

Recent Modern Literature 400

Introduction to Chaucer 400

\section{Requirements:}

American Literature 200

Earlier British Literature 300

Later British Literature 300

Modern British Literature 300

Required Core Courses:

British Literature to 1798300

British Literature Since 1798300

American Literature to 1865300

American Literature Since 1865300

\section{Requirements:}

British Literature to 1800300

British Literature 1800-Present 300 American Literature Survey $300(0)$ 
juxtaposes those three types of English major curricula with evidences of the field coverage model. To represent the Type 1.0 curriculum in this context, I chose the Gordon College curriculum to represent a tripodal model containing remnants of the field or historical coverage of literature. I could just as well have chosen the Eastern Mennonite University curriculum, for it also had a tripod structure and required courses given to eras and authors taught in the traditional canon. Two instances illustrated this: ENG 351 Renaissance Literature and ENG 451 Shakespeare.

Among the selected $20 \mathrm{CCCU}$ English curricula, vestiges of field coverage appeared readily, too, among those Type 1.0 majors with core-and-periphery structures. Although I chose Lee University, with its ENG 415 Milton and ENG 441 Victorian Literature courses, to represent this state, both Westmont College and Wheaton College curricula also had courses redolent of the old canon's historical eras and authorsincluding junior-level courses treating Milton and the $17^{\text {th }}$ century.

Vestiges of the field coverage model appeared among the selected CCCU English curricula which were Type 1.5 Primarily Literature, but these plans tended to have coreand-periphery structures rather than the tripodal organization seen in the Dordt College English curriculum (noted in Table 8). The Malone College curriculum represented the more usual Type 1.5 curricula with a core-and-periphery structure, and that of Oklahoma Christian University represented the same kind. Both curricula had required and elective courses bearing similar titles such as "British Literature Since 1798" and "Shakespeare." Vestigial evidence of the field coverage of literature also appeared among the 20 selected curricula categorized as Type 2.0 More Flexible English majors with core-andperiphery structures. Goshen College served as the example for Table 8; however, Bethel 
College (MN), King College, and Seattle Pacific University also had required eras and movements. However, I could not identify among the 20 a Type 2.0 major that structured elective courses whose titles reflected British and American historical periods, authors, or as the old tripod of literature, composition, and grammar. To find one, I returned to the entire CCCU English curricula and scanned all First Look cards to find only one such case-that of Oklahoma Wesleyan University-whose Type 2.0 curriculum appeared so tripodal during my first close reading that I drew a tripod on its index card. The structure proved unique among Type 2.0 curricula.

This situation suggested that the further an English curriculum departed from Stewart's Modified Type 1.0 Straight Literature, the more its structure appeared to be organized as core-and-periphery. I use the word "appeared," rather than "became" to avoid inferring a causal link at work. To rephrase my point, I observe that among the purposeful sampling of CCCU English curricula, those modeled on the old tripod paradigm of English tended to be literature dominated and to have strong evidence of the field coverage model. The Type 2.0 More Flexible English curricula had core-andperiphery structures, yet still retained some evidence of that model's use of historical eras, authors, and movements.

Vestiges of historical coverage appeared more readily among the purposeful sample of 20 CCCU English curricula than did signs of innovation. To note any such evidence, I scanned both the First Look cards and journal entries to discern innovation in the content, organization, and presentation of these curricula. Apart from literature courses dealing with Christian concerns (discussed below, under the second research question), few suggested unusual and/or innovative content. Three minor innovations or 
unusual content features did occur: (a) Dordt College in the American Midwest offered Canadian literature, while Redeemer University College in Canada listed American Literature; these courses seemed less innovative than reflective of the Reformed Christian network of clientele living in adjacent nations, (b) Goshen College, a Mennonite school, offered a unique course entitled "Mennonite Literature," and (c) Redeemer University College, influenced by its British tradition, provided differing tiers of difficulty with its "Honours Major" and "General Major." These three situations, however, remained minor; no sweeping innovation appeared among the content of the purposeful sampling.

Neither did any sign of organizational or structural innovation appear. I noted nothing unusual among the structures of the 20 selected curricula; nor did I find any innovation in their presentation except in the packaging of the Oklahoma Christian University Type 1.5 Primarily Literature English major. Packaging provided a Pre-Law emphasis which differed only by a directive for the choice of minor(s), an English/ Writing major, which required 21 hours of upper-level literature and between 15 to 21 of writing, two English/TEFL, and two English education majors. So, the apparent innovations reflected cosmetic packaging rather than true innovation.

\section{Content of the Curricula}

Research question 1e asked, What content appeared in the CCCU curricula and its aggregate English major curriculum? Which categories (if any) received emphasis, and which little or no attention? What courses appeared, and how were their descriptions written?

To address this question, I prepared Content Categories cards for each of the 20 selected English curricula; I did so after having closely read each earlier, when I prepared 
the First Look cards. The Content Categories cards allowed me to group courses, to check my earlier notes, and to record additional specifics and commentary. Categories included literature, linguistics (including grammar), rhetoric, writing, journalism, media writing, and "other" for miscellaneous courses. As journalism and media studies sometimes provided common courses such as news writing, I combined the two into an inclusive category. As before, I excluded freshman-level courses.

Then I applied those content cards to the 20 selected curricula according to their types; I analyzed all Type 1.0 Straight Literature curricula first $(N=11)$; then Type 1.5 Primarily Literature curricula $(N=4)$; and, last, Type 2.0 More Flexible curricula $(N=5)$. After completing a Content Categories Card for each of the 20 curricula, I made tables for each type to record the titles and numbers of courses under each discrete category (e.g., literature). I occasionally had to judge where to place a course whose official title did not readily identify its content; for instance, "Writing to Be Read" at Seattle Pacific proved from its description to be a course in advanced composition.

Having categorized the courses offered by the three types of curricula among the selected $20 \mathrm{CCCU}$ schools, I recorded the ranges of required and elective courses for each type. Tables 9 through 12 present those findings in the following order: Type 1.0 Straight Literature; Type 1.5 Primarily Literature; and Type 2.0 More Flexible curricula. My observations appear below in that order. Type 1.0 curricula, representing 11 of the 20, revealed three particular emphases-genre, British/English literature, and American literature. For genre offerings such as "poetry" the required courses among the 11 ranged from 0 to 6; for British/English literature, required genre courses ranged from 0 to 4; and, for American literature, they ranged from 0 to 3 (as shown on Table 9). Finding these 
Table 9

Content Category Ranges for Type 1.0 English Curricula in Sampling $(N=11)$

Subject Area/

Courses Offered
Range of Required ${ }^{\mathrm{a}}$

Courses Offered
Range of Additional ${ }^{\mathbf{a}}$

Courses Offered

\section{Literature Content:}

$\begin{array}{lll}\text { American } & 0-3 & 2-5 \\ \text { British/English Literature } & 0-4 & 0-7 \\ \text { World Literature } & 0-2 & 0-1 \\ \text { Theory and/or Criticism } & 0-1 & 0-1 \\ \text { Other: Genre } & 0-6 & 0-4 \\ \text { Other: Christian-related } & 0-3 & 0-4 \\ \text { Other: Senior Seminar/Capstone } & 0-1 & 0-1\end{array}$

Linguistics Content:

Grammar

$0-1$

$0-1$

Descriptive Linguistics

$0-1$

$0-4$

History of English Language

$0-1$

$0-1$

Rhetoric:

Composition

0-1

$0-1$

Advanced Composition

$0-1$

$0-1$

Writing:

Creative writing

0-2

0-2

Nonfiction writing

0

$0-1$

Journalism/Media Writing:

News writing $\quad 0$

$0-1$

Editing

0

$0-1$

Other:

Internship

0

$0-1$

${ }^{a}$ Independent study courses were excluded. 
ranges caused me to recheck my data; I wondered why genre studies had greater ranges than British/English or American literature survey courses.

My figures proved accurate, and I determined a probable explanation for the findings: It lay in the assigning of genre courses to cover both literatures. For instance, a study of the $19^{\text {th }}$-century novel could cover works by British writers from Austen to Eliot, as well as the American writers from Hawthorne to James. Apparently, former historical era courses had been recast as double coverage genre courses. I suggested this reasoning tentatively, due to course descriptions lacking specific details (such as those given "Studies in Fiction" and "Studies in Poetry" by Dallas Baptist University).

After genre courses, the next widest range of required literature courses for Type 1.0 curricula fell to British/English courses: 0 to 4 . Wondering what roles survey courses and Shakespeare courses played in this statistic, I found these results: 5 to 6 of these (11) curricula required one to two survey courses in British/English literature at the 200 and 300 levels; 5 to 6 also required (each) one course in Shakespeare, and nearly all appeared at the 300 level. One curriculum accounted for the latitude in this range (of 5 to 6); Westmont College offered two different tracks in its program, but its Graduate Study preparation track required two survey courses and one upper-level Shakespeare course not required by its Writing Track. British/English literature courses also represented the largest of elective courses ( 0 to 7$)$.

After British/English literature courses, American literature had the next largest range of required courses for Type 1.0 Straight Literature curricula: 0-3. General surveys represented the usual courses. Seven of the 11 curricula required at least one survey of American literature; 6 to 7 plans required two such surveys (and, again, tracks in the 
Westmont plan accounted for the latitude). All these survey courses appeared at the 200 and 300 levels, and they dominated the required courses. Among electives, courses in British/English literature had the widest range of offerings-from 0 to 7 . This statistic was followed by American literature, whose course offerings ranged from 2 to 5 .

Courses in world literature and Christian-related literature also figured within the Type 1.0 curricula, but numerically not as large as genre, British/English literature, and American literature courses. Required courses in world literature ranged from 0 to 2, and electives from 0 to 1 . Required courses in Christian-related literature numbered from 0 to 3 , and electives from 0 to 4 . As slight as these ranges were, that of the senior seminar or capstone course proved smaller, as did the range of literary theory and/or literary criticism offerings.

Whereas literature dominated the Type 1.0 curricula, other study categories included linguistics, rhetoric, writing, and journalism/media. Linguistics offered three common courses, though their titles differed: grammar, descriptive linguistics, and the history of the English language. The range for each of these courses proved identical and small: 0 to 1 for required courses. For elective credit, the ranges differed somewhat: grammar and history of the language shared a range of 0 to 1 , while linguistics ranged from 0 to 4 . Clearly, in contrast to literature, linguistics appeared slighted.

Rhetoric also received slight attention among the 11 Type 1.0 Straight Literature curricula in the purposeful sampling. Required courses in composition ranged from 0 to 1 ; in advanced composition, required courses also ranged from 0 to 1 . Elective courses in both composition and advanced composition shared the range of 0 to 1 . No other courses appeared in this category-not one about the theory of composition-a notable omission 
in contrast to theory courses for literature which, despite the protests of Spanos (1989), have become common among undergraduate English majors.

Writing had two courses in its domain: creative writing and nonfiction writing. The first ranged from 0 to 2 for required courses among the 11 curricula; the second domain did not have any required courses. For elective courses, creative writing ranged from 0 to 2 ; nonfiction ranged from 0 to 1 . No other courses appeared under the writing category for Type 1.0 curricula: Writing appeared as slighted therein as rhetoric. Indeed, the evident under-emphasis on writing/composition, rhetoric, and linguistics (including grammar) corresponded to the traditional paradigm of English—-the tripod dominated by literature. The presence of elective journalism courses with ranges of 0 to 1 appeared to be the exception that proved the rule.

Type 1.5 Primarily Literature English curricula, representing 4 of the selected 20, or $20 \%$, showed a dominance of British/English and American literature similar to that of the Type 1.0 curricula. For Type 1.5 curricula, the range of required courses in British/ English literature extended from 2 to 3 , whereas the range of elective courses was 1 to 3 (as shown in Table 10). The range of required courses in American literature numbered 2, whereas that of elective courses was 1 to 2 . World literature among Type 1.5 curricula ranged in number from 0 to 1 for required courses, and from 1 to 2 for electives.

Three courses common to Type 1.5 and Type 1.0 curricula had similar ranges. First, literary theory and/or criticism ranged from 0 to 1 for required courses among Type 1.5 curricula, and from 0 to 1 among Type 1.0. The same range appeared for this course as electives among both types. Second, Christian-related literature courses were not required among the Type 1.5 curricula, but ranged from 0 to 3 among Type 1.0 programs. 
Table 10

Content Category Ranges for Type 1.5 English Curricula in Sampling $(N=4)$

Subject Area/

Range of Required ${ }^{a}$

Range of Additional ${ }^{\mathrm{a}}$

Courses Offered

Courses Offered

Courses Offered

\section{Literature Content:}

American Literature

British/English Literature

2

1-2

World Literature

2-3

$1-3$

Theory and/or Criticism

1

$0-1$

1-2

Genre

0

$0-1$

Other: Christian-related

0

2-4

Other: Canadian literature

$0-3$

Other: Themes

0

$0-1$

Other: Authors

0

$0-1$

Other: Sophomore Seminar

0

$0-1$

Other: Senior Seminar/Capstone

$0-1$

0

Other: African American Literature

$0-1$

$0-2$

Other: Women Writers

0

$0-1$

Other: Topics, etc.

0

$0-1$

Other: Christian-related Literature

0

$0-3$

0

$0-1$

Linguistics Content:

Grammar

Descriptive Linguistics

0

$0-1$

History of English Language

0

$0-1$

0

$0-1$

Rhetoric:

Composition

Advanced Composition

Writing:

Creative Writing

0

$0-1$

Business/Technical

0

$0-1$

Other:

Internship

0-1

0-3

Practicum

0

$0-1$

Travel

0

$0-2$

Introduction to English Studies

0

$0-1$

${ }^{a}$ Independent study courses were excluded. 
Such courses as electives among Type 1.5 curricula ranged from 0 to 3; among Type 1.0, they ranged from 0 to 4 . Third, senior seminar/capstone courses as requirements ranged from 0 to 1 among Type 1.5 curricula, and also from 0 to 1 among Type 1.0 programs. That course as an elective ranged from 0 to 2 among Type 1.5, and 0 to 1 among Type 1.0 curricula.

Two literature-based courses common to Types 1.5 and 1.0 curricula indicated greater difference among their ranges. Genre courses were not required among the Type 1.5 curricula, but ranged from 2 to 4 for electives; genre courses required among Type 1.0 curricula ranged from 0 to 6 , and those serving as electives ranged from 0 to 4 . Christian-related literature courses were not required among Type 1.5 plans, but as electives they ranged from 2 to 4 offerings. Such courses among Type 1.0 requirements ranged from 0 to 3 , and as electives from 0 to 4 .

The most significant difference between the Type 1.5 Primarily Literature and the Type 1.0 Straight Literature majors among the 20 appeared in the diversity of elective literature courses among the Type 1.5. Included were Canadian literature, African American literature, themes in literature, topics in literature, major authors, and women writers. None of these courses appeared as discrete entities among the Type 1.0 curricula $(N=11$ of 20). If their subject material appeared at all among this purposeful sampling, it figured within courses such as surveys.

So, whereas Type 1.5 Primarily Literature curricula proved more oriented to requiring survey courses in British/English and American literatures than did Type 1.0 Straight Literature curricula, the former also had a greater number and diversity of 
literature courses. But in three other categories, the two curriculum types shared remarkable similarity.

Three main categories of content for the undergraduate English major showed considerable similarity between Type 1.5 and Type 1.0 curricula in requirement course ranges and elective course ranges. First, linguistics content, as shown by Tables 10 and 11, showed that grammar, descriptive linguistics, and history of the English language served as the only subject matters for both curricular types. (Table 12 supports this fact indirectly, as writing programs at Type 1.0 colleges, including Colorado Christian University, Houghton College, and Westmont College, have not increased in number.) Courses offered in grammar, linguistics, and history of the language were not required by any Type 1.5 curricula $(N=4$ of 20$)$; they were required by only one Type 1.0 program ( $N=11$ of 20). As electives, courses in these subjects showed ranges of 0 to 1 -with just one exception. The range for descriptive linguistics offered by Type 1.0 curricula was from 0 to $4(N=11)$. This reflected, I think, the presence of English as a second language (ESL) and Teaching English as a Second Language (TESL) through several different programs among 6 of the 11 Type 1.0 curricula (as noted under "Patterns," and Table 19). Beside linguistics, rhetoric represented another main content category showing similar ranges for the Type 1.5 Primarily Literature and the Type 1.0 Straight Literature curricula. Composition as a required course ranged from 0 to 1 among both Type 1.0 curricula $(N=11)$ and Type $1.5(N=4)$ in the purposeful sampling $(N=20)$. Advanced composition ranged from 0 to 1 among Type 1.0 programs, but was not required by any Type 1.5. As electives, composition and advanced composition offerings ranged from 0 to 1 for both types. 
Table 11

Content Category Ranges for Type 2.0 English Curricula in Sampling $(N=5)$

Subject Area/

Range of Required

Courses Offered

Courses Offered ${ }^{\mathrm{a}}$

Range of Additional

Courses Offered ${ }^{\mathbf{a}}$

\section{Literature Content:}

American Literature

British/English Literature

$2-3$

$0-4$

World Literature(s)

2-4

2-7

Western

$0-2$

$0-2$

Other National (e.g., Canadian)

$0-1$

$0-2$

Other: Area (e.g., African)

Minority Lit. in American Literature:

$\begin{array}{lll}\text { African American } & 0 & 0-3 \\ \text { Asian American } & 0 & 0-1 \\ \text { Ethnic American } & 0 & 0-1 \\ \text { Native American } & 0 & 0-1 \\ \text { Women } & 0 & 0-2 \\ \text { Combination } & 0-1 & \end{array}$

Other: Literature by

Genre(s)

0

$0-4$

Author(s): Shakespeare

$0-3$

$0-5$

Themes

$0-1$

$0-1$

Literature in Britain/etc.

Topics in Literature

0

$0-1$

Literature and Film

0

0-2

0

0-1

Literary Theory/Criticism (3-400)

Practical Criticism (200)

0-1

$0-1$

0-1

0

Sophomore Seminar

$0-1$

0

Senior Seminar/Capstone

$0-1$

0

English Practicum/Internship

0

$0-1$

Senior Project

0-1

0 
Table 11-Continued.

Subject Area/

Courses Offered
Range of Required

Courses Offered ${ }^{\mathrm{a}}$
Range of Additional

Courses Offered ${ }^{2}$

Literature Content continued:

Christian-related:

Mennonite Literature

C.S. Lewis

Other

$0-1$

0

$0-2$

0

$0-1$

\section{Linguistic Content:}

Grammar

Descriptive Linguistics

$0-1$

History of English Language

0

0

$0-1$

Other: TESL

Rhetoric:

Composition

Advanced Composition

$0-1$

$0-1$

Debate

0

$0-1$

Argumentation \& Debate

0

$0-1$

Theory/Theory and Practice/

0

$0-1$

Composition \& Rhetoric (Theory)

\section{Writing:}

Creative Writing (Unspecified)

Writing Poetry

Writing Fiction

Writing Creative Nonfiction

Writing Nonfiction/Feature

Magazine Writing

Publishing/Publication

Professional Writing

Business/Technical Writing

0

$0-1$

Writing for Public Relations 
Table 11-Continued.

Subject Area/

Courses Offered
Range of Required

Courses Offered ${ }^{2}$
Range of Additional

Courses Offered ${ }^{\mathrm{a}}$

Writing continued:

Life Writing

Play Writing

Film Scripting

0

0

0

Science Writing/Environment

Travel Writing

Electronic Media Writing

Business/Technology/Industry

Student Publication Labs

Practicum (On and Off Campus)

Internship(s)
$0-1$

$0-1$

$0-1$

$0-1$

$0-1$

$0-1$

$0-1$

$0-4$

$0-1$

$0-2$

Journalism:

Basic Journalism

News Writing/Reporting

Advanced Journalism

Journalism Workshop

0

$0-1$

$0-1$

$0-1$

0

$0-1$

0

$0-1$

\section{Other:}

Film (non-literary, but under English)

$0-1$

Drama (non-literary, but under English) 0

$0-1$

${ }^{a}$ Independent study courses were excluded. 
Table 12

Increase of Writing Programs Among Purposeful Sampling of CCCU English Curricula $(N=20)$

\section{0-2001 CCCU \\ Members}

Sources: Catalog(s)

Years(s) or Web Site
Writing Programs

Available 1997-1998

Title (Semester Hours

at 200-400 Levels)
Writing Program

Available 2000-2003

Title (Semester Hours

at 200-400 Levels)

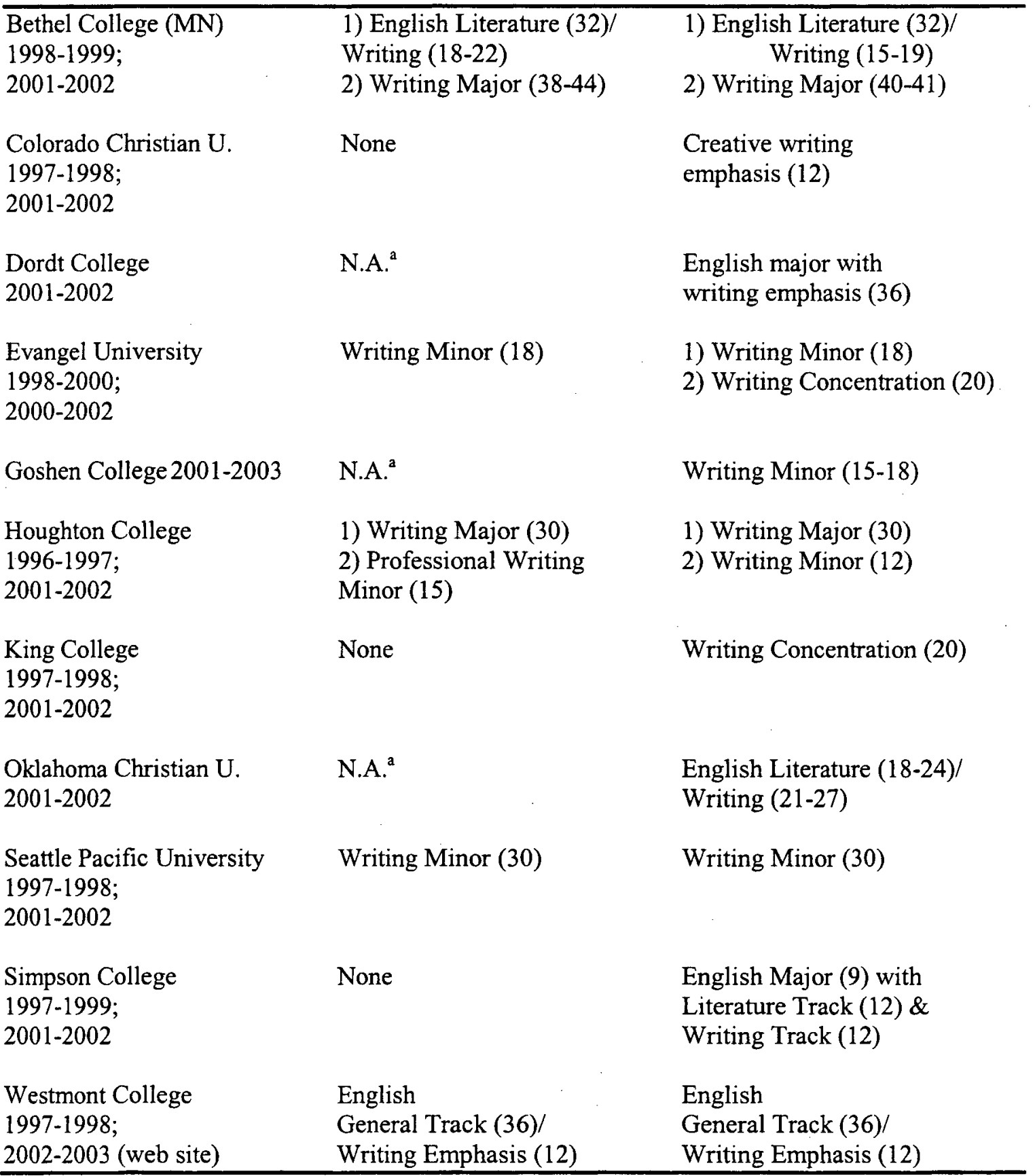

${ }^{a}$ N.A. means the curriculum was not available. 
The third main content category showing similarity between Types 1.5 and 1.0 curricula was writing. Tables 9 and 10 indicate that creative writing as a requirement ranged from 0 to 2 among Type 1.0 programs $(N=11$ of 20$)$, but was not required by Type 1.5 curricula $(N=4)$. Among electives, creative writing again ranged from 0 to 1 among Type 1.0 programs, but from 0 to 1 among Type 1.5. The similarity ended here, as the types differed on their other offering: nonfiction appeared as an elective for Type 1.0 programs, ranging from 0 to 1 , thus suggesting its insignificance to that type $(N=11)$, whereas business/technical writing appeared as an elective for Type 1.5 curricula $(N=4)$, ranging from 0 to 1 and thus showing its lack of emphasis.

The two curricular types differed decidedly in the remaining content categories. Though Type $1.5(N=4)$ curricula proved more eclectic in content, with courses given to introductions to English Studies and to travel, they gave more attention to practical and career experience than did Type 1.0 curricula. Included among the Type 1.5 programs were internships and practicum courses. Required internships ranged from 0 to 1 among the Type 1.5 curricula, whereas elective internships ranged from 0 to 3. No Type 1.5 program required a practicum, which as an elective ranged from 0 to 1 . The Type 1.0 Straight Literature major curricula $(N=11)$ made no requirements among the final category of journalism/media writing, but did offer electives in news writing, editing, and internship with each ranging from 0 to 1 . Three strong characteristics of Types 1.0 and 1.5, as shown by Table 9 and Table 10, included (a) the dominance of British/English and American literatures, (b) the presence of minority literature offerings, and, most strikingly, (c) the proliferation of electives among the content areas of literature and writing. The dominance of British/English and American literatures among the five Type 
2.0 More Flexible curricula corresponded closely to that dominance among the four Type 1.5 Primarily Literature plans.

For Type 2.0 the range of required courses for British/English literature extended from 2 to 4 , compared to the range of 2 to 3 among the Type 1.5 curricula. The range of electives for British/English literature among the Type 2.0 programs, however, extended from 2 to 7 in contrast to the range of 2 to 3 for Type 1.5 plans. The range of required courses in American literature among Type 2.0 went from 2 to 3, whereas each Type 1.5 curriculum required 2 American literature courses. Type 2.0, identified as the More Flexible major, represented 5 of the 20 selected curricula. The range of additional, elective courses among the Type 2.0 curricula proved greater, from 0 to 4 , than the range of 1 to 2 found among Type 1.5 programs.

The appearance of minority literature electives within American literature made a marked difference for Type 2.0 More Flexible curricula compared to other, previously discussed curricular types. Among the five Type 2.0 curricula were six different minority literature course; these and their respective ranges included African American literature ranging from 0 to 3; Asian American literature ranging from 0 to 1; Ethnic American literature ranging from 0 to 1; Native American literature ranging from 0 to 1; Women's American literature ranging from 0 to 1 ; and combinations of minority literature courses ranging from 0 to 2. An example of such a combination stood in the Bethel College (MN) curriculum as "Literature of the Oppressed." Another example appeared in the Goshen College (IN) catalog as “ENGL 207, 307 Interdisciplinary Literature.” This last course was a topical study whose offerings included "African-American Literature," "Women in Literature," and, notably, "Mennonite Literature." 
Thus, minority literatures helped to account for course proliferation under the Type 2.0 "Literature Content" category, but other offerings also contributed.

Concomitant to world literature were Western literature and area literatures including African and Asian. Of them, only Western literature appeared as a required course; thus, it ranged from 0 to 1 , but as an elective from 0 to 2 . Other literatures ranged from 0 to 2 . Literature courses offered on location abroad, especially in Britain, also added electives which ranged among these curricula from 0 to 2. Other electives, each with a range of 0 to 1 , served to enlarge the Type 2.0 curricula: literature and film, practical criticism, English practicum/internship, and the senior project.

The other content area beside literature which expanded markedly among Type 2.0 curricula was writing. Creative writing, one of two writing topics each for Types 1.0 and 1.5, proliferated into multiple topics for Type 2.0 : writing poetry, writing fiction, writing nonfiction, and writing creative nonfiction. Each of these electives, with one exception, ranged from 0 to 1 ; writing poetry went from 0 to 2 . Practical courses related to or supportive of these creative writing offerings appeared: magazine writing, publishing, electronic media writing, as well as practicum and internship experiences. All but the latter ranged from 0 to 1 ; internships ranged from 0 to 2 . The result, apparent on Table 13, was a burgeoning of courses related to creative writing.

Courses related to professional writing also appeared in contrast to simply one business/technical elective offered by the Type 1.5 curricula. Among Type 2.0 were electives treating science/environment writing, travel writing, and professional writing. Each elective increased the English curricula by a range of 0 to 1 , but the impact of these additions created a swollen periphery of electives. 
This observation related to the structures of these five Type 2.0 curricula: Each had core-and-periphery organization (as shown by Table 11). A proliferation of writing, minority literature, and other literature courses occurred among electives; core courses, represented by British/English and American literatures, remained required but few in number. A comparison and contrast of Type 2.0 and Type 1.5 required courses (listed in Tables 10 and 11) indicates their cores shared emphases on British/English and American literature courses (often, surveys). Type 2.0, however, listed 30 courses beyond those given among Type 1.5 curricula. Only two of them were requirements.

Therefore, the Type 2.0 More Flexible curricula $(N=5)$ among the 20 selected CCCU English curricula represented core-and-periphery majors dominated by British/English and American literatures, given to minority literature electives, and characterized by the proliferation of elective literature and writing courses assigned to their peripheries.

\section{Patterns Evident Among the Curricula}

Research question $1 \mathrm{f}$ asked, What patterns appeared within the content of these CCCU English curricula? To address this, I reviewed the First Look cards, Content Organization cards, charts drawn from those cards, and journals kept while I explored the entire curricula, and then focused on the 20 curricula in the purposeful sample. I also reviewed four global patterns already observed (above); namely, that (a) Type 1.0 Straight Literature curricula tended to be structured according to the traditional tripod model of English; (b) Type 1.5 Primarily Literature curricula tended to reflect the coreand-periphery structure, with British/English and American literatures dominating the core; (c) Type 2.0 More Flexible curricula depended solely on core-and-periphery 
structure; and (d) Type 2.0 were characterized by the proliferation of electivesespecially in minority literatures and in writing.

A fifth discernible pattern appeared with the increased number of writing programs. Among the 20 selected curricula, 5 definitely offered writing programs in the 1997-1998 academic year (as shown in Table 12), whereas 3 definitely did not. By 2001, 11 of the 20 curricula offered such programs. Four of those 11 had incorporated writing as an emphasis or track within the English major, but two provided writing majors discrete from any English programs. Seven writing minors, concentrations, or emphases among six different schools appeared independent from any English major programs.

So, the pattern revealed all CCCU schools, especially the larger, were expanding their curricula in writing around the year 2000. Why was the increase in writing programs significant? The pattern suggested that change was transpiring within CCCU individual curricula and aggregate curriculum. The traditional tripod structure was teetering slightly, giving more leverage to writing. That change may have reflected the rise of composition/writing studies in the 1980 s, noted in chapter 1 , including Lloyd-Jones and Lunsford's (1989) call for writing/composition to comprise the centrality of English studies, as well as Elbow's (1990) observation that "writing could serve as a [new] paradigm for English" (pp. 130-131). If writing/composition studies gained among CCCU curricula, literature admitted adjustment. One compromise in the curriculum occurred by incorporating writing into the English major itself; as Table 12 indicates, by the 2002-2003 academic year 5 of the selected 20 CCCU members had English/ Writing majors or English Majors with writing tracks or emphases. 
The second reason that the addition of writing programs to CCCU curricula at the turn of the century appeared significant lay with its potential impact on teaching loads. Table 13 shows that the 4 of the 20 curricula which added writing programs (namely, Colorado Christian University, Evangel University, King College, and Simpson College) had heavy teaching loads for their faculties. Colorado Christian University reported only five full-time faculty and two adjuncts serving a student body numbering 2,000. At Evangel University, six full-time faculty served a student body numbering 600. Finally, at Simpson College, four full-time English faculty and two adjuncts served a student a body of over 1,300. These numbers suggested that CCCU English faculty carried teaching loads made heavier by the addition of writing programs - unless courses were seldom scheduled or were taught by adjuncts.

This same pattern of added writing programs also materialized within the total population of CCCU schools as shown by Appendix F. Among the 47 members offering such programs by 2003,12 did not offer writing programs during the 1997-98 year. These included schools whose enrollments then ranged from 600-plus (e.g., King College) to 5,000-plus (e.g., Oral Roberts University); 7 of the 12 had enrollments exceeding 1,200 .

A sixth pattern emerged among the purposeful sampling of 20 CCCU English curricula: "Shakespeare" remained a required course, listed most often at the junior level, for nine schools or $45 \%$ (as shown on Table 14). Among the 11 Type 1.0 Straight Literature curricula, 3 required Shakespeare courses at the junior level, and 1 at the senior level. Among Type 1.5 Primarily Literature curricula, one of four schools required the study of Shakespeare, whereas among Type 2.0 More Flexible schools two of five 
Table 13

Faculty Supporting Writing Programs Among Purposeful Sampling of CCCU English Curricula $(N=20)$

\begin{tabular}{|c|c|c|c|c|c|}
\hline $\begin{array}{l}\text { Institution } \\
\text { (State/ } \\
\text { Province) }\end{array}$ & $\begin{array}{l}\text { Reported } \\
\text { Enrollment } \\
\text { (Catalog } \\
\text { Years) }\end{array}$ & $\begin{array}{l}\text { Stewart's } \\
\text { Modified } \\
\text { Type } \\
\text { Major }\end{array}$ & $\begin{array}{l}\text { No. of } \\
\text { Faculty/ } \\
\text { Full } \\
\text { Time }\end{array}$ & $\begin{array}{ll}\text { No. of } & \mathbf{y} \\
\text { Faculty/ } & 0 \\
\text { Part } & \\
\text { Time } & \end{array}$ & $\begin{array}{l}\text { Writing Program(s) } \\
\text { Offered }\end{array}$ \\
\hline $\begin{array}{l}\text { Bethel C. } \\
(\mathrm{MN})\end{array}$ & $\begin{array}{l}2,149 \\
(1997-1998)\end{array}$ & $\begin{array}{l}2.0 \\
\text { with } 3 \\
\text { versions }\end{array}$ & $\begin{array}{l}7 \text { Engl } \\
2 \mathrm{Wtg}\end{array}$ & $\begin{array}{l}1 \text { Engl } \\
1 \mathrm{Wtg}\end{array}$ & $\begin{array}{l}\text { 1) English Literature (32) } \\
\text { /Writing (15-19) } \\
\text { 2) Writing Major (40-41) }\end{array}$ \\
\hline Colorado C.U. & $\begin{array}{l}2,000 \\
(1997-1998)\end{array}$ & 1.0 & 5 Engl & 2 Engl & $\begin{array}{r}\text { Creative writing } \\
\text { emphasis (12) }\end{array}$ \\
\hline Dallas Bapt. U. & $\begin{array}{l}4,302 \\
(2002-2004)\end{array}$ & 1.0 & 4 Engl & 17 Engl & \\
\hline Dordt C. & $\begin{array}{l}\text { c. } 1,400 \\
(2001-2002)\end{array}$ & 1.5 & 6 Engl & NA & $\begin{array}{l}\text { English major with writing } \\
\text { emphasis ( } 36)\end{array}$ \\
\hline Evangel U. & $\begin{array}{l}\text { NA } \\
(2000-2002)\end{array}$ & 1.5 & 6 Engl & 0 listed & $\begin{array}{l}\text { 1) Writing Minor (18) } \\
\text { 2) Writing Concen.(20) }\end{array}$ \\
\hline $\begin{array}{l}\text { Eastern } \\
\text { Mennonite U. }\end{array}$ & $\begin{array}{l}\text { c. } 1,400 \\
(2001-2002)\end{array}$ & 1.0 & 7 Engl & 1 Engl & \\
\hline Gordon C. & $\begin{array}{l}1,528 \\
(2001-2002)\end{array}$ & 1.5 & 6 Engl & 1 Engl & \\
\hline Goshen C. & $\begin{array}{l}1,041 \\
(2001-2003)\end{array}$ & 2.0 & 6 Engl & 1 Engl & Writing Minor (15-18) \\
\hline Houghton C. & $\begin{array}{l}1,400 \\
(2001-2002)\end{array}$ & 1.0 & 9 Engl & 0 listed & $\begin{array}{l}\text { 1) Writing Major (30) } \\
\text { 2) Writing Minor (12) }\end{array}$ \\
\hline King C. & $\begin{array}{l}608 \\
(2001-2002)\end{array}$ & 2.0 & 5 Engl & $\begin{array}{l}4-5 \text { staff } \\
\text { lecturers }\end{array}$ & Writing Concen. (20) \\
\hline Lee U. & $\begin{array}{l}3,000 \\
(2001-2002)\end{array}$ & 1.5 & 14 Engl & N.A. & \\
\hline Malone C. & $\begin{array}{l}2,100 \\
(2001-2002)\end{array}$ & 1.5 & $\begin{array}{l}8 \text { Engl } \\
\text { (1 E. Ed) }\end{array}$ & N.A. & \\
\hline
\end{tabular}


Table 13-Continued.

\begin{tabular}{|c|c|c|c|c|c|}
\hline $\begin{array}{l}\text { Institution } \\
\text { (State/ } \\
\text { Province) }\end{array}$ & $\begin{array}{l}\text { Reported } \\
\text { Enrollment } \\
\text { (Catalog } \\
\text { Years) }\end{array}$ & $\begin{array}{l}\text { Stewart's } \\
\text { Modified } \\
\text { Type } \\
\text { Major }\end{array}$ & $\begin{array}{l}\text { No. of } \\
\text { Faculty/ } \\
\text { Full } \\
\text { Time }\end{array}$ & $\begin{array}{l}\text { No. of } \\
\text { Faculty/ } \\
\text { Part } \\
\text { Time }\end{array}$ & $\begin{array}{l}\text { Writing Program(s) } \\
\text { Offered }\end{array}$ \\
\hline $\begin{array}{l}\text { Northwest } \\
\text { Nazarene U. }\end{array}$ & $\begin{array}{l}1,250 \\
(2001-2002)\end{array}$ & 1.0 & $6 \mathrm{Engl}$ & N.A. & \\
\hline $\begin{array}{l}\text { Oklahoma } \\
\text { Christian U. }\end{array}$ & $\begin{array}{l}2,100 \\
(2001-2002)\end{array}$ & $1-4.5$ & 9 Engl & N.A. & $\begin{array}{l}\text { Literature (18-24)/ } \\
\text { Writing (21-27) }\end{array}$ \\
\hline $\begin{array}{l}\text { Palm Beach } \\
\text { Atlantic C. }\end{array}$ & $\begin{array}{l}2,400 \\
(2001-2002)\end{array}$ & 1.0 & $\begin{array}{l}8 \text { Engl } \\
2 \text { Lit. }\end{array}$ & 4 Engl & \\
\hline $\begin{array}{l}\text { Redeemer } \\
\text { University C. }\end{array}$ & $\begin{array}{l}\text { NA } \\
(2000-2002)\end{array}$ & 1.0 & 3 Engl & 1 Engl & $\begin{array}{l}\text { Honours Major \& } \\
\text { General Major }\end{array}$ \\
\hline $\begin{array}{l}\text { Seattle } \\
\text { Pacific U. }\end{array}$ & $\begin{array}{l}2,636^{a} \\
(2001-2002)\end{array}$ & 2.0 & 8 Eng1 & $1-2 \mathrm{Wtg}$ & Writing Minor (30) \\
\hline Simpson C. & $\begin{array}{l}1,300^{\mathrm{b}} \\
(2001-2002)\end{array}$ & 2.0 & 4 Engl & 2 Engl & $\begin{array}{l}\text { English Major (9) } \\
\text { with } \\
\text { Literature Track (12) \& } \\
\text { Writing Track (12) }\end{array}$ \\
\hline Westmont C. & $\begin{array}{l}\text { N.A. } \\
(2002-2003)\end{array}$ & 1.0 & 8 Engl & N.A. & $\begin{array}{l}\text { English Gen. Track (36)/ } \\
\text { Writing Emphasis (12) }\end{array}$ \\
\hline $\begin{array}{l}\text { Wheaton C. } \\
\text { (IL) }\end{array}$ & $\begin{array}{l}\text { N.A. } \\
(2001-2002)\end{array}$ & 1.0 & 9 Engl & $\begin{array}{l}3 \text { Engl/ } \\
7 \text { V.F. }\end{array}$ & \\
\hline
\end{tabular}

\footnotetext{
${ }^{a}$ Source was the institutional web site.

${ }^{\mathrm{b}}$ Undergraduate enrollment numbered only of 3,427 total enrollment. Data from Peterson's, $7^{\text {th }}$ th Ed. of Christian Colleges \& Universities.

${ }^{\mathrm{c}}$ V.F. $=$ Visiting Faculty.
} 
Table 14

Shakespeare Course Required Among Purposeful Sampling of CCCU English Curricula $(N=20)$

$\begin{array}{llll}\text { Stewart's Modified } & \text { Total } & \text { Number Requiring } & \text { Number Requiring } \\ \text { Type of English } & \text { Number } & \text { Shakespeare at } & \text { Shakespeare at } \\ \text { Major Curriculum } & & \text { Junior Level } & \text { Senior Level }\end{array}$

Type 1.0

11

3

1

Straight Literature

Type 1.5

4

0

1

Primarily Literature

Type 2.0

5

2

1

More Flexible

schools required this course at the junior level and another required it at the senior. In every instance, courses in Shakespeare studies appeared within the curricular core and never on the periphery. Retaining the Shakespeare course in the core of the major represented a conservative act to critics who descry the canon's demise (Thomas, 2000).

Type 1.5 Primarily Literature English curricula $(N=4)$ among the selected 20 showed a similar burgeoning of junior-level courses. The number of their sophomore-level courses ranged from 2 to 14; their junior-level courses from 15 to 26; and their senior-level courses from 1 to 17 . Their averages (rounded off) were seven 200-level courses, 18300 level courses, and six 400-level courses. Each of the four curricula placed literature surveys, especially in British/English and American literatures, at the junior levels. Also, three of the four had author courses at this level. The fourth, the Malone College 
curriculum, offered two unspecified literature courses in advanced topics and advanced studies. Evidently, the historical coverage of literature retained by Type 1.5 curricula occurred through surveys and author studies especially at the 300 level.

Type 2.0 Primarily Literature English curricula $(N=5)$ among the selected 20 also showed the pattern of having a large offering of 300-level courses. The number of their sophomore courses ranged from 4 to 11 ; their junior offerings from 12 to 44 ; and their senior courses from 1 to 17 . Their averages, rounded off to the nearest whole number, were seven sophomore courses, 18 junior courses, and six senior courses.

This imbalance of course offerings suggested that further research at the syllabus level be pursued to discern its effect(s) on the scope-and-sequence of undergraduate courses, their goals and objectives, and their means of achieving them. For this study, the imbalance evident on Tables 15 through 17 pointed to a concern - that is, the accretion of elective courses beyond core requirements.

The imbalance of course offerings, with the majority listed at the junior-year level, had a related pattern evident among the 20 selected CCCU English curricula: They tended to assign (or, perhaps, retain) historical coverage courses in literature at the 300 level. Thus, literature courses covering historical eras such as the Renaissance, the Romantic period, and the Victorian era helped to swell course offerings at the junior-year level. Table 18 indicates that 12 of the 20 selected curricula shared historical coverage literature courses at both the 300 and 400 levels, but especially at the former. Whereas these 12 represented mainly Type 1.0 Straight Literature curricula $(N=7)$, the other types also had historical coverage courses at the junior and senior levels. 
Table 15

Total Courses for Type 1.0 English Major in Purposeful Sampling of CCCU Curricula $(N=11)$

$\begin{array}{llll}\text { CCCU Member } & \text { Number of 200 } & \text { Number of 300 } & \text { Number of 400 } \\ \text { (Catalog Years) } & \text { Level Courses } & \text { Level Courses } & \text { Level Courses }\end{array}$

Christian U.

(2001-2002)

Dallas Baptist U.

2

6

10

(2002-2004)

Eastern Mennonite U.

$9^{\mathrm{a}}$

$9^{\mathrm{a}}$

9

(2001-2002)

Gordon College

9

11

4

(2001-2002)

Houghton College

9

14

4

(2001-2002)

Lee University

5

15

20

(2001-2002)

Northwest Nazarene U.

11

23

7

(2001-2002)

Palm Beach Atlantic C. 5

17

19

(2001-2002)

Redeemer U.C.

4

14

8

(2000-2002)

Westmont College

$5^{\mathrm{ac}}$

$30^{\mathrm{c}}$

$3^{\mathrm{c}}$

$(2002-2003)^{b}$

Wheaton College

3

21

10

\footnotetext{
${ }^{a}$ Included were literature, theater, and communication courses.

${ }^{\mathrm{b}}$ Source was institutional web site.

c These represent course number equivalents.
} 
Table 16

Total Courses for Type 1.5 English Major in Purposeful Sampling of CCCU Curricula $(N=4)$

\begin{tabular}{llcl} 
CCCU Member & Number of 200 & Number of 300 & Number of 400 \\
(Catalog Years) & $\begin{array}{l}\text { Level Courses } \\
\text { Offered }\end{array}$ & $\begin{array}{l}\text { Level Courses } \\
\text { Offered }\end{array}$ & $\begin{array}{l}\text { Level Courses } \\
\text { Offered }\end{array}$ \\
\hline
\end{tabular}

\begin{tabular}{lccc}
$\begin{array}{l}\text { Dordt College } \\
(2001-2002)\end{array}$ & 14 & 26 & 0 \\
$\begin{array}{l}\text { Evangel University } \\
(2000-2002)\end{array}$ & 8 & 17 & 11 \\
$\begin{array}{l}\text { Malone College } \\
(2001-2002)\end{array}$ & 3 & 15 & 4 \\
$\begin{array}{l}\text { Oklahoma Ch. U. } \\
(2001-2002)\end{array}$ & 2 & 15 & 6 \\
\hline
\end{tabular}

Table 17

Total Courses for Type 2.0 English Major in Purposeful Sampling of CCCU Curricula $(N=5)$

\begin{tabular}{lccc}
$\begin{array}{l}\text { CCCU Member } \\
\text { (Catalog Years) }\end{array}$ & $\begin{array}{l}\text { Number of 200 } \\
\text { Level Courses } \\
\text { Offered }\end{array}$ & $\begin{array}{l}\text { Number of 300 } \\
\text { Level Courses } \\
\text { Offered }\end{array}$ & $\begin{array}{l}\text { Number of } 400 \\
\text { Level Courses } \\
\text { Offered }\end{array}$ \\
\hline $\begin{array}{l}\text { Bethel C. (MN) } \\
(2001-2002)\end{array}$ & $11^{\mathrm{a}}$ & $25^{\mathrm{a}}$ & $3^{\mathrm{a}}$ \\
$\begin{array}{l}\text { Goshen College } \\
(2001-2003)\end{array}$ & $4^{\mathrm{a}}$ & $16^{\mathrm{a}}$ & 2 \\
$\begin{array}{l}\text { King College } \\
(2001-2002)\end{array}$ & 9 & 44 & 1 \\
$\begin{array}{l}\text { Seattle Pacific U. } \\
(2001-2002)\end{array}$ & 9 & 20 & 17 \\
$\begin{array}{l}\text { Simpson College } \\
(2001-2002)\end{array}$ & 8 & 13 & 6 \\
\hline
\end{tabular}

${ }^{a}$ Included are literature, writing, and/or language courses. 
To make the pattern of historical coverage more discernible, Table 18 includes indisputable instances of its occurrence through course such as "Renaissance" literature. Less obvious offerings appeared in other ways: for instance, English 313 and 314 entitled "English Literature II Survey" at Evangel University represented amalgamated historical periods packaged as a second, more advanced set of survey courses in British/English literature. Another amalgamation, one restricted to genre, occurred in the Northwest Nazarene University curricula, wherein English 335 and 336 "The British Novel" extended over multiple historical eras, as evidenced by their respective full titles: "The British Novel: Beginning through Dickens," and "The British Novel: Hardy to the Present." Another instance by which historical eras appeared amalgamated, especially at the 300 level, was by major author and period: For instance, "Milton and the Seventeenth Century" was offered by Bethel College (MN) and Gordon College (MA), and "The Age of Milton" by Evangel University (MO), and all as 300-level courses.

A final pattern I observed did not occur within the English curricula themselves, but often in concert with them: namely, the offering of studies in Teaching English as a Second Language (TESOL or TESL), Teaching English to Speakers of Other Languages (also TESOL), Teaching English as a Foreign Language (or TEFL), and English as a Second Language (ESL). Nine of the 20 selected CCCU English curricula were within schools having courses and/or programs in TESOL-type studies external to the English curricula. As Table 19 indicates, 2 of the 20 selected schools offered major programs: Bethel College (MN) had both TESOL and TEFOL majors, and Oklahoma Christian University had an English/English Teaching Major with Teaching English as a Foreign Language (TEFL). 
Table 18

Historical Coverage of Literature Excluding Initial Surveys in Purposeful Sampling of CCCU English Curricula $(N=20)$

\begin{tabular}{|c|c|c|c|c|c|c|c|c|}
\hline \multirow[t]{2}{*}{$\begin{array}{l}\text { CCCU Member } \\
\text { (Catalog Year) }\end{array}$} & \multirow{2}{*}{$\begin{array}{l}\text { Stewart's } \\
\text { Modified } \\
\text { Type Major }\end{array}$} & $\begin{array}{l}\text { Renaissance/ } \\
\text { Equivalent }\end{array}$ & \multicolumn{2}{|c|}{$\begin{array}{l}\text { Romanticism/ } \\
\text { Equivalent }\end{array}$} & \multicolumn{2}{|c|}{$\begin{array}{l}\text { Victorian/ } \\
\text { Equivalent }\end{array}$} & \multicolumn{2}{|c|}{$\begin{array}{l}20^{\text {th }} \text {-Century/ } \\
\text { Equivalent }\end{array}$} \\
\hline & & $300 \quad 400$ & 300 & 400 & 300 & 400 & 300 & 400 \\
\hline $\begin{array}{l}\text { Bethel C. }(\mathrm{MN}) \\
(2001-2002)\end{array}$ & $\begin{array}{l}2.0 \text { More } \\
\text { Flexible }\end{array}$ & $\mathrm{x}$ & $\mathrm{x}$ & & $\mathrm{x}$ & & $\mathrm{x}$ & \\
\hline $\begin{array}{l}\text { Dallas Bapt. U. } \\
(2002-2004)\end{array}$ & $\begin{array}{l}\text { 1.0 Straight } \\
\text { Literature }\end{array}$ & & & & & $\mathrm{x}$ & & \\
\hline $\begin{array}{l}\text { E. Mennonite U. } \\
(2001-2002)\end{array}$ & $\begin{array}{l}\text { 1.0 Straight } \\
\text { Literature }\end{array}$ & $\mathrm{x}$ & $\mathrm{x}$ & & $\mathrm{x}$ & & & $\mathrm{x}$ \\
\hline $\begin{array}{l}\text { Evangel U. } \\
(2000-2002)\end{array}$ & $\begin{array}{l}\text { 1.5 Primarily } \\
\text { Literature }\end{array}$ & & & & & $\mathrm{x}$ & & \\
\hline $\begin{array}{l}\text { Houghton C. } \\
(2001-2002)\end{array}$ & $\begin{array}{l}\text { 1.0 Straight } \\
\text { Literature }\end{array}$ & $\mathrm{x}$ & $\mathrm{x}$ & & & & $\mathrm{x}$ & \\
\hline $\begin{array}{l}\text { King C. } \\
(2001-2002)\end{array}$ & $\begin{array}{l}2.0 \text { More } \\
\text { Flexible }\end{array}$ & & $x$ & & $\mathrm{x}$ & & $\mathrm{x}$ & \\
\hline $\begin{array}{l}\text { Lee U. } \\
(2001-2002)\end{array}$ & $\begin{array}{l}\text { 1.0 Straight } \\
\text { Literature }\end{array}$ & & & $\mathrm{x}$ & & $x$ & & $\mathrm{x}$ \\
\hline $\begin{array}{l}\text { Palm Beach } \\
\text { Atlantic C. } \\
(2001-2002)\end{array}$ & $\begin{array}{l}\text { 1.0 Straight } \\
\text { Literature }\end{array}$ & $\mathrm{x}$ & $\mathrm{x}$ & & $\mathrm{x}$ & & $\mathrm{x}$ & \\
\hline $\begin{array}{l}\text { Redeemer U.C. } \\
(2000-2002)\end{array}$ & $\begin{array}{l}1.0 \text { Straight } \\
\text { Literature }\end{array}$ & $\mathrm{x}$ & $\mathrm{x}$ & & $\mathbf{x}$ & & $\mathrm{x}$ & \\
\hline $\begin{array}{l}\text { Seattle Pac. U. } \\
(2001-2002)\end{array}$ & $\begin{array}{l}2.0 \text { More } \\
\text { Flexible }\end{array}$ & $\mathrm{x}$ & $\mathrm{x}$ & & $\mathrm{x}$ & & $\mathrm{x}$ & \\
\hline $\begin{array}{l}\text { Westmont C. } \\
(2002-2003)\end{array}$ & $\begin{array}{l}\text { 1.0 Straight } \\
\text { Literature }\end{array}$ & $x^{a}$ & $x^{a}$ & & $\mathrm{x}^{\mathrm{a}}$ & & $x^{a}$ & \\
\hline $\begin{array}{l}\text { Wheaton C. } \\
(2001-2002\end{array}$ & $\begin{array}{l}\text { 1.0 Straight } \\
\text { Literature }\end{array}$ & $\mathrm{x}$ & $\mathrm{x}$ & & $\mathrm{x}$ & & $\mathrm{x}$ & \\
\hline
\end{tabular}

${ }^{\mathrm{a}}$ Equivalent course level. 
Table 19

TESOL and Related Offerings Among CCCU Purposeful Sampling ( $N=20)$

CCCU Member Stewart's Modified TESOL/TESL Other:

(Catalog Years) Type Major Major / Minor

Eastern Mennonite U. 1.0 Straight Lit. (2001-2002)

Lee U.

1.0 Straight Lit.

$\mathrm{x}$

(2001-2002)

Palm Beach At. U. 1.0 Straight Lit.

ESL Endorsement

(2001-2002)

Dordt C.

1.5 Primarily Lit.

ESL Endorsement

(2001-2002)

Oklahoma

Christian U.

1.5 Primarily Lit.

1) TEFL w/ Eng.

(2001-2002)

2) TEFL Minor

Bethel C. (MN)

2.0 More Flexible

$\mathrm{x}$

$\mathrm{x}$

TEFL

(2001-2002)

Goshen C.

2.0 More Flexible

X

(2001-2003)

Seattle Pacific U. 2.0 More Flexible

ESL

(2001-2002)

Simpson C.

(2001-2002)

1 TESOL course for English 
Five CCCU institutions offered minor programs in TESOL, TESL, or TEFL. According to the purposeful sampling of 20, no type of English curriculum was more likely than another to be linked to a TESOL-type program. Yet, the pattern of having TESOL-type instruction available among a large minority of CCCU curricula was evident - a pattern found, too, in the larger population where $34 \%(N=101)$ offered TESOL-type courses and programs.

In summary, the following patterns appeared during my exploration of the purposeful sampling of 20 CCCU English major curricula: (a) Tripod structure of the Type 1.0 Straight Literature curricula, (b) Core-and-periphery organization of the Type 1.5 Primarily Literature curricula, (c) Core-and-periphery structure of the Type 2.0 More Flexible curricula, (d) Proliferation of electives among Type 2.0 curricula, (e) Increase between 1997 and 2002 in writing programs, (f) Continuation of a Shakespeare course as a requirement, (g) Concentration of major courses at the 300 levels and consequent imbalance of offerings, (h) Appearance of (or perhaps retention of) historical coverage courses among the 300 and 400 levels, and (i) Existence of TESOL or TESOL-type instruction among one-third of the CCCU curricula (but not necessarily within the English major curricula).

\section{Weaknesses and Strengths}

Research question $1 \mathrm{~g}$ asked, What curricular weaknesses and strengths, as well as slights and emphases, appeared among the individual curricula and the CCCU aggregate English curriculum? In response to this, I reported major weaknesses first and then major strengths. 


\section{Weaknesses}

Leading the weaknesses of the Type 1.0 Straight Literature curricula was its inadequate attention to writing, composition, and rhetoric. This type represented 11 of the 20 curricula comprising the purposeful sample, but offered only three writing programs (as shown by Table 20). Notably, two of the three separated their English and writing programs: Bethel College (MN) and Houghton College (NY). Such a disjunction seemed unwarranted two decades into the Writing Across the Curriculum movement.

A second major weakness among the Type 1.0 Straight Literature major curricula appeared in their relative inattention to world and/or non-Western literatures, and the paucity of minority literatures among them. That is, they continued to adhere to the traditional canon of British/English and American literatures. Table 15 supports this observation, revealing by ranges the dominance of required and elective courses given these two literatures, as well as the scarcity of minority literature offerings.

Contrasting the dominance of Western literature, especially that of British/English and American literatures, to the increasing diversity of Western societies, I noted the dated nature of the Type 1.0 curricula. So, I identified this inadequate attention to nonwestern and minority literatures as the second most-serious concern for this type.

Identifying serious weaknesses of the Type 1.5 Primarily Literature major curricula among the purposeful sample of 20 proved more difficult because they were fewer in number $(N=4)$ than the Type 1.0. Given the size limitation, the two types appeared quite similar in nature, as both stressed literature and slighted writing/ composition/rhetoric. In the latter category, two of the four Type 1.5 curricula offered four or fewer such courses. Dordt College and Evangel University each offered Table 20 


\begin{tabular}{llll}
$\begin{array}{l}\text { CCCU } \\
\text { Member } \\
\text { (Catalog } \\
\text { Years) }\end{array}$ & $\begin{array}{l}\text { Stewart's } \\
\text { Modified } \\
\text { Type of } \\
\text { Major }\end{array}$ & $\begin{array}{l}\text { Writing } \\
\text { Major } \\
\text { (Hours) }\end{array}$ & $\begin{array}{l}\text { English/Writing } \\
\text { Major } \\
\text { or Variation } \\
\text { (Hours) }\end{array}$ \\
\hline $\begin{array}{l}\text { Bethel C. (MN) } \\
\text { (2001-2001) }\end{array}$ & $\begin{array}{l}\text { Flexible } \\
\text { Fonore }\end{array}$ & $40-41$ & $\begin{array}{l}\text { English Lit. (32)/ } \\
\text { Writing (15-19) }\end{array}$ \\
$\begin{array}{l}\text { Colorado } \\
\text { Christian U. } \\
\text { (2001-2002) }\end{array}$ & Literature & & \\
$\begin{array}{l}\text { Dordt C. } \\
\text { (2001-2002) }\end{array}$ & Literature & & \\
\end{tabular}

\begin{tabular}{|c|c|c|c|}
\hline $\begin{array}{l}\text { Evangel U. } \\
(2000-2002)\end{array}$ & $\begin{array}{l}\text { 1.5 Primarily } \\
\text { Literature }\end{array}$ & & \\
\hline $\begin{array}{l}\text { Goshen College } \\
(2001-2003)\end{array}$ & $\begin{array}{l}2.0 \text { More } \\
\text { Flexible }\end{array}$ & & \\
\hline $\begin{array}{l}\text { Houghton C. } \\
(2001-2002)\end{array}$ & $\begin{array}{l}\text { 1.0 Straight } \\
\text { Literature }\end{array}$ & 30 & \\
\hline $\begin{array}{l}\text { King College } \\
(2001-2002)\end{array}$ & $\begin{array}{l}\text { 1.5 Primarily } \\
\text { Literature }\end{array}$ & & \\
\hline $\begin{array}{l}\text { Oklahoma } \\
\text { Christian U. } \\
\text { (2001-2002) }\end{array}$ & $\begin{array}{l}\text { 1.5 Primarily } \\
\text { Literature }\end{array}$ & & $\begin{array}{l}\text { English Lit } \\
(18-24) / \\
\text { Writing }(21-27)\end{array}$ \\
\hline $\begin{array}{l}\text { Seattle Pacific } \\
(2001-2002)\end{array}$ & $\begin{array}{l}2.0 \text { More } \\
\text { Flexible }\end{array}$ & & \\
\hline $\begin{array}{l}\text { Simpson C. } \\
(2001-2002)\end{array}$ & $\begin{array}{l}2.0 \text { More } \\
\text { Flexible }\end{array}$ & & \\
\hline
\end{tabular}

\begin{abstract}
English Major/
English E. (36)

Writing E. (36)
\end{abstract}

Writing Writing

(18)

(20)

Writing

(15-18)

Writing

(12)

Creative

Writing

E. (12) 
four writing/composition courses to student bodies respectively numbering 1400 and 1564 (Council for Christian Colleges and Universities, 2001, pp. 43 \& 49). Such weakness in writing/composition/rhetoric also characterized those Type 1.5 Primarily Literature curricula not in the purposeful sampling. According to the First Look cards, 8 of the 29 Type 1.5 curricula in the population of 98 CCCU English curricula, or $28 \%$ of the population, slighted writing/composition/rhetoric.

Thus, I have observed so far that inattention to writing, composition, and rhetoric represented the most serious weakness of both Types 1.0 and 1.5 English major curricula sampled, as shown in Table 21.

Another weakness shared by Type 1.0 and Type 1.5 seemed even more evident among the Type 1.5 Primarily Literature curricula. Within the purposeful sampling, this type showed a slightly larger imbalance of courses among upper levels of instruction. Tables 15 and 16 (above) provide comparisons of the types for numbers and levels of offerings. Type 1.0 curricula averaged 6 courses at the 200 level and Type 1.5 averaged 7; Type 1.0 averaged 16 courses at the 300 level and Type 1.5 averaged 18 . At the 400 level, both types averaged 9 courses. This observed imbalance, however, remained tentative as I did not address the scheduling of courses.

I did, however, maintain records on the number of English faculty members listed among the official academic catalogs and bulletins of the 2000-2001 CCCU members. Table 13 (above) reported the number of faculty supporting the 20 selected CCCU curricula that comprised my purposeful sample. For Type 1.5 curricula, the number of full-time faculty ranged from 6 to 9 , while enrollments ranged from circa 1,400 to 2,100 , and total course offerings from 23 at Oklahoma Christian University to 40 at Dordt 
Table 21

Leading Weaknesses Among CCCU Purposeful Sampling $(N=20)$

\begin{tabular}{|c|c|c|c|c|c|}
\hline Observed Weakness & $\begin{array}{l}\text { Type } 1.0 \\
\text { Straight } \\
\text { Literature } \\
\text { Curriculum } \\
(N=11)\end{array}$ & $\begin{array}{l}\text { Type } 1.5 \\
\text { Primarily } \\
\text { Literature } \\
\text { Curriculum } \\
(N=4)\end{array}$ & $\begin{array}{l}\text { Type } 2.0 \\
\text { More } \\
\text { Flexible } \\
\text { Curriculum } \\
(N=5)\end{array}$ & Total & Percentage \\
\hline Lack of goals/objectives & 4 & 3 & 2 & 9 & 45 \\
\hline $\begin{array}{l}\text { Little emphasis on writing } \\
\text { (i.e., few courses, few } \\
\text { required courses) }\end{array}$ & 5 & 1 & 2 & 8 & 40 \\
\hline $\begin{array}{l}\text { Imbalance of course offerings } \\
\text { among undergraduate } \\
\text { levels }(200-400)\end{array}$ & 2 & 2 & 3 & 7 & 35 \\
\hline $\begin{array}{l}\text { Little emphasis on linguistics/ } \\
\text { grammar/history of English } \\
\text { language (i.e., few courses, } \\
\text { few required courses) }\end{array}$ & 3 & 2 & 2 & 7 & 35 \\
\hline $\begin{array}{l}\text { Little emphasis on } \\
\text { composition/rhetoric (i.e., } \\
\text { few courses, few required } \\
\text { courses) }\end{array}$ & 3 & 1 & 2 & 6 & 30 \\
\hline $\begin{array}{l}\text { Little emphasis on } \\
\text { non-Western/world/ } \\
\text { multicultural literature } \\
\text { (i.e., few courses, few } \\
\text { required courses) }\end{array}$ & 2 & 1 & 2 & 5 & 25 \\
\hline $\begin{array}{l}\text { Lack of practical/career- } \\
\text { related courses and/or } \\
\text { opportunities }\end{array}$ & 2 & 2 & 1 & 5 & 25 \\
\hline $\begin{array}{l}\text { Little emphasis on } \\
\text { minority literature (i.e., } \\
\text { few courses, few } \\
\text { required courses) }\end{array}$ & 2 & 1 & 1 & 4 & 20 \\
\hline $\begin{array}{l}\text { Courses proliferating at } \\
\text { periphery around } \\
\text { required core }\end{array}$ & 2 & 2 & 2 & 4 & 20 \\
\hline
\end{tabular}


College (shown on Table 16). Figures remained unavailable and/or incomplete, however, for part-time faculty. Since the relationship of faculty numbers to curricular courses affects the taught, if not the printed, curriculum, Type 1.5 curricula within the sample appeared to require heavy teaching loads for their faculty.

This suggested another weakness among Type 1.5 curricula, not only at Dordt with its 1,400 students, six full-time English faculty, and 40 course curriculum, but also at Evangel University, Malone College, and Oklahoma Christian University. Beyond the schools included in the purposeful sampling, four other Type 1.5 curricula may have over-extended their faculty loads (according to the First Look cards): these included Abilene Christian University, Eastern Nazarene College, Southwest Baptist University, and Warner Southern College. Certainly for Type 1.5 Primarily Literature curricula among the total CCCU membership, 8 of 29 (for $28 \%$ ) appeared to create heavy teaching loads for their English faculty.

Two expected weaknesses of the Type 2.0 More Flexible English curricula also appeared within the purposeful sample: a proliferation of elective courses in the periphery of these core-and-periphery-structured curricula, and an imbalance of course offerings among the various undergraduate levels. As explained in chapter 1, this type of structure and organization has been characterized by the addition of electives outside the core requirements. The purposeful sampling of 20 contained five of this type (i.e., the 2.0 More Flexible) curricula reflecting its structure of a small core of requirements surrounded by a continually expanding periphery of electives.

Two Type 2.0 English curricula within the purposeful sampling illustrated the characteristic, swelling periphery of electives: the Bethel College (MN) and Seattle 
Pacific University English major curricula. The core of the former, while allowing prescriptive choices such as Chaucer, Milton, or classicism-to-romanticism courses, represented the traditional canon of British/English and American literatures. Its periphery, however, represented the non-traditional literatures including "Literature of the Oppressed," and "Modern Mythmakers in Fiction and Film" (Bethel College Catalog, 2001-2002, 2001, pp. $112 \& 126)$. The core of the latter curriculum also represented the traditional canon except in one prescriptive choice of an ancient, classical, or modern literature (e.g., Russian Writers). The periphery, meanwhile, offered several nontraditional courses such as Asian Literature and English Practicum (Seattle Pacific University Undergraduate Catalog, 2001-2002, 2001, pp. 129-132).

Though both Bethel College (MN) and Seattle Pacific University had student enrollments exceeding 2,000 at the turn of the century, both reported having English and writing faculties numbering fewer than 10 members as shown on Table 13 (above). Such a situation suggested the likelihood of heavy teaching loads-a problem often associated with an expanding periphery of electives-as well as the possibility that the curricula may have been attempting too much.

Also associated with an expanding periphery of elective courses was a second weakness evident among the Type 2.0 curricula $(N=5)$ in the purposeful sampling. This was an imbalance of course offerings among the differing levels of instruction. Table 17 (above) indicates that all five Type 2.0 English curricula among the sampling of 20 offered far more junior-level courses than sophomore or senior courses. King College provided the most egregious example of an expanding periphery of electives: 44 at the junior level. These contrasted to nine sophomore courses and one senior course. As King 
College then enrolled 608 students and had five full-time English faculty members, its many 300 -level courses pointed to heavy teaching loads, scheduling problems, and the need to review the scope and sequence of course content.

Thus, Type 2.0 English curricula indicated these two weaknesses: a plethora of elective courses within the periphery of their core-and-periphery structures, and an imbalance of course offerings at the 300 level. Perhaps both weaknesses testify to a curriculum in transition-a possibility to be discussed in chapter 5 .

So far, I have identified three weaknesses each for Types 1.0 and 1.5, and two for Type 2.0 English major curricula among the CCCU schools represented in my purposeful sampling of 20 (shown in Table 21). As an aggregate entity, the sampling evidenced two significant weaknesses: the lack of published purposes, goals, and/or objectives of the major; and the need to give writing/composition/rhetoric greater emphasis.

The first aggregate weakness found in the purposeful sampling was the lack of published purposes, goals, and objectives. This situation surprised me during the early stages of my research, causing me to wonder how any curriculum could convey its mission and aims to its various clientele without articulating its aims. Perhaps in some instances, including Bethel College (IN) where I teach, goals have been articulated by the faculty, distributed for departmental use, and yet omitted from the catalog. I fault myself for this omission, and ask how I could expect undergraduates to apprehend the English major without receiving any introductory statement of its purpose, claims, directives, or guidelines. Nine of the 20 selected curricula shared this fault.

The evident lack of published goals among the purposeful sampling made me wonder whether any of the remaining 78 curricula showed this weakness. To determine 
this, I took another sampling of every seventh curriculum among those not in the first sampling. I asked whether introductions to these curricula (a) included goals and/or objectives, (b) listed disciplinary-related information, such as career associations, and/or program directives, such as hours required, (c) represented minimal, perfunctory statements, or (d) did not appear. I did not provide for "other" responses as I recognized that these four served my purposes. I applied these same questions, as well, to the first, purposeful sampling in order to compare the two samplings.

Tables 22 and 23 record my observations about the lack of published purposes and goals among the CCCU curricula. These tables report on the first, purposeful sampling, and a second random sampling I made as a check on the first. In the earlier, purposeful sampling of 20,2 (or 10\%) had articulated goals which truly were goals or aims; 15 (or 75\%) had introductions which conveyed discipline-related information such as the value of studying literature, and/or directives such as required courses and sequences. Three (or 15\%) lacked written introductions to their programs.

For the second sampling of 11 curricula not involved in the first, results showed that 4 or $36 \%$ identified goals and/or objectives within their introductions; 5 or $45 \%$ gave discipline-related information and/or directives; one or nine percent had only a minimal introduction. (Percentages were rounded off.)

When the results for the two samplings were compared, both showed that the discipline-related/directive-type introduction dominated. This proved especially true for the first, purposeful sampling of 20 curricula wherein $75 \%$ of responses occurred in this category; for the second sampling of 11 , this same category dominated, but to a lesser extent with $45 \%$. Both samplings showed that articulated goals did not characterize the 
Table 22

Introductions to Curricula in Purposeful Sampling of CCCU English Curricula $(N=20)$

\begin{tabular}{lllll}
\hline & $\begin{array}{l}\text { Has introduction } \\
\text { with goals and/or } \\
\text { objectives for the }\end{array}$ & $\begin{array}{l}\text { Has introduction with } \\
\text { discipline-related } \\
\text { information (e.g., } \\
\text { English major }\end{array}$ & $\begin{array}{l}\text { Has minimal } \\
\text { cCCU Members) and/or directives }\end{array}$ & Has no \\
(Catalog Year) & introduction & \\
\hline
\end{tabular}

Bethel C. (MN)

$\mathbf{X}$

(2001-2002)

Colorado Ch. U.

(2001-2002)

$\mathbf{X}$

Dallas Baptist U.

(2002-2004)

$\mathrm{x}^{\mathrm{a}}$

Dordt C.

$\mathrm{X}$

(2001-2002)

Evangel U.

(2000-2002)

E. Mennonite U.

$\mathrm{x}$

(2001-2002)

Goshen C.

$\mathrm{X}$

(2001-2003)

Gordon C.

(2001-2002)

X

Houghton C.

(2001-2002)

$\mathrm{X}$

King C.

X

(2001-2002)

Lee U.

$\mathbf{x}$

(2001-2002)

Malone C.

(2001-2002)

NW Nazarene U.

$\mathbf{X}$

(2001-2002) 
Table 22-Continued.

\begin{tabular}{lllll}
\hline & $\begin{array}{l}\text { Has introduction } \\
\text { with goals and/or } \\
\text { objectives for the } \\
\text { English major }\end{array}$ & $\begin{array}{l}\text { Has introduction with } \\
\text { discipline-related } \\
\text { information (e.g., } \\
\text { careers) and/or directives }\end{array}$ & $\begin{array}{l}\text { Has minimal } \\
\text { introduction }\end{array}$ & $\begin{array}{l}\text { Has no } \\
\text { introduction }\end{array}$ \\
\hline
\end{tabular}

Oklahoma Ch. U.

$\mathbf{X}$

(2001-2002)

Palm Beach

X

Atlantic U.

(2001-2002)

Redeemer

X

University C.

(2000-2002)

Seattle Pacific U.

$\mathrm{x}$

(2001-2002)

Simpson C.

(2001-2002)

X

Westmont C.

$\mathbf{X}$

(2002-2003)

Wheaton C.

(2001-2002)

$\mathrm{X}$

${ }^{\mathrm{a}}$ The given goals actually represent department rather than student goals. 
Table 23

Introductions to English Curricula in a Random Sampling of CCCU Schools $(N=11)$

Has introduction with goals and/or objectives for the

CCCU Member (Catalog Years)
English major
Has introduction with

discipline-related

information (e.g.,

subject areas, careers) and/or directives
Has minimal introduction
Has no introduction

Bethel C. (KS)

(2001-2002)

Campbellsville U.

$(2001-2003)^{\mathrm{a}}$

East Texas Baptist U. $\quad \mathrm{x}$

(2001-2002)

Grace C.

$\mathbf{X}$

(2001-2002)

Indiana Wesleyan U.

(2001-2003)

MidAmerica Naz. U. $\quad x$ (2001-2002)

Northwestern C. (IA)

(2001-2002)

Roberts Wesleyan C.

(2000-2002)

Tabor C.

(2001-2002)

Union U.

X

(2001-2002)

William Tyndale C. (2001-2002)

$\mathrm{X}$

X

X

$\mathrm{X}$

${ }^{\mathrm{a}}$ Source was institutional web site. 
CCCU curricula: Merely $10 \%$ of the first, purposeful sampling and $36 \%$ of the second identified such goals. Thus, on the basis of two samplings, I observed the lack of identified, published purposes and goals among the aggregate CCCU curriculum.

The second aggregate weakness apparent in the purposeful sampling was its inadequate attention to writing, composition, and rhetoric - interrelated subjects referred to among some English organization publications as writing/composition and/or writing/rhetoric. To suggest the state of these subjects within the total CCCU curriculum, I returned to Tables 9-11, which report ranges of course offerings. These tables offered comparative information supporting my concern that writing, composition, and rhetoric received inadequate attention within this sampling.

Composition as a required course appeared only within Type 1.0, the Straight Literature English major, with its frequency ranging from 0 to 1 (as indicated on Table 9). Within that type, it ranged also from 0 to 1 as an elective course. For Type 1.5 , the Primarily Literature major, composition as a required course ranged from 0 to 1 ; as an elective, it ranged from 1 to 2 . For Type 2.0, the More Flexible major, composition as a required course ranged from 0 to 1 ; it had the same range as an elective course.

Advanced composition as a requirement for Type 1.0 curricula ranged from 0 to 1, and did the same as an elective. Although no Type 1.5 curriculum required advanced composition, as an elective for this type offerings for that course ranged from 0 to 1 . For Type 2.0 curricula, advanced composition as a required course ranged from 0 to 1 ; as an elective course it had the same range.

Thus, the three types of English major curricula, according to Tables 9-11, showed little attention to composition and to advanced composition within the printed 
curricula. However, writing courses other than expository writing/composition courses received greater attention among them all.

Writing studies among Type 1.0 majors, as shown by Table 9, meant creative writing, ranging as required study from 0 to 2 offerings just as it did as an elective. No Type 1.0 curriculum required nonfiction writing, but as an elective it had from 0 to 1 offerings. These two subjects and other electives in news writing, editing, and interning in journalism and/or the media, represented the scope of writing studies apart from composition studies. Type 1.5 curricula gave similar attention to non-composition writing studies. Table 10 identified creative writing as an elective only, with a range from 0 to 1 . Replacing nonfiction (found in the Type 1.0 major) was an elective in business writing or technical writing, with each ranging from 0 to 1 . No regular courses in journalism were offered among Type 1.5 curricula, although a required internship (which may have included placement in journalism) ranged from 0 to 1 , and an elective internship ranged from 0 to 3 . Additional opportunities for writing studies occurred within other elective courses involving travel or practicum experience, which ranged respectively from 0 to 2 and from 0 to 1 .

Among the Type 2.0 More Flexible curricula, writing studies burgeoned-as illustrated by Table 11 . Type 2.0 listed, as had Type 1.5 , creative writing and business/technical writing courses, but it had 15 additional writing courses. These included genre courses, such as writing poetry and writing fiction; subject area studies, such as writing for public relations and science writing; and writing profession studies such as professional writing, magazine writing, and electronic media writing. Each course 
among the 15 represented an elective, and each ranged from 0 to 1 , except for writing poetry, which ranged from 0 to 2 .

What this proliferation of elective courses suggested was the acknowledgment among Type 2.0 curricula that writing within the major needed greater attention; what the limited ranges of these additions suggested was experimentation to meet that need. Supporting these suppositions were my findings on the increased number of writing programs among the purposeful sampling. Table 12 showed that between 1997 and 2002 four of the 20 added such programs: Colorado Christian University added a creative writing emphasis; Evangel University added a writing concentration; King College added a writing concentration; and Simpson College redesigned its English major and made writing one of two new tracks offered. Data remained unavailable for three schools' 1997-98 English curricula whose 2001-2002 curricula did provide writing programs. One college did reduce its number of writing programs: Houghton College consolidated three differentiated writing minors into one, flexible minor. Presumably, this move strengthened its curriculum. Among the sampling, the change indicated an increase in writing programs and a new emphasis on writing.

\section{Strengths}

The strengths apparent among the purposeful sampling of 20 CCCU English curricula represented mainly content strengths, but included one opportunity strength; this observation arose from the lists of course offerings recorded for the three types of English majors (in Tables 9-11). Content strengths, of course, concerned the various subject areas within English and pertained to academics, while the opportunity strength 
concerned career-oriented experiences. The latter supported academics through skill development, and especially extended beyond classroom instruction.

Content strengths numbered three with the leading strength representing literature. For the three types of Stewart's Modified English Majors represented among the purposeful sampling of 20 curricula, British/English and American literatures provided the mainstay. Among the 11 Type 1.0 Straight Literature majors, required courses in British/English and American literature ranged respectively from 0 to 4 and from 0 to 3 . These traditional literatures accounted, as well, for the largest ranges of electives, with 0 to 7 for British/English literature and 2 to 5 for American literatures (as shown on Table 9).

Among Type 1.5 Primarily Literature curricula $(N=4)$, required courses in British/English and American literature ranged respectively from 2 to 4 and from 2 to 3 . Elective courses for the two literatures ranged respectively from 2 to 7 and from 0 to 4 (as shown in Table 10). One elective represented a minority literature within American literature: African American literature. Although not a required course, it furthered the role of American literature as a mainstay of Type 1.5 curricula.

The mainstay of Type 2.0 More Flexible English curricula $(N=5)$ also proved to be English/British and American literatures. Among the purposeful sampling of 20 CCCU curricula, as shown on Table 11, the former ranged from 2 to 4 offerings as required studies, and from 2 to 7 as elective studies. The latter had a range for required offerings from 2 to 4 , and for electives a range from 0 to 4 . As in the Type 1.5 curricula, but even more so among Type 2.0 majors, minority literature courses emerged as 
electives within American Literature. These especially included African American, Asian American, Ethnic American, and Native American literatures.

A second strength related directly to the dominant role literature played among the CCCU English curricula; namely, the inclusion of literary history and/or literary criticism. The content of the first subject usually set forth a historical progression of seminal essays on the reading and interpreting of texts, such as "On the Sublime" and "On the Defence of Poetry." The content of the second subject, however, usually set forth critical movements and/or approaches to the interpretation of texts, such as New Criticism, which dominated critical methodology during the mid-20th century and the New Historicism born in reaction to it. The purposeful sampling of 20 CCCU English curricula indicated that 16 , or $80 \%$, offered courses in literary history (sometimes referred to as literary theory) and/or literary criticism. Not surprisingly, Type 1.0 Straight Literature and Type 1.5 Primarily Literature curricula required such courses more than the Type 2.0 More Flexible curricula did (as shown on Tables 24-26). Among the 11 Type 1.0 curricula, 8 (or nearly $73 \%$ ) provided such a course or courses; 5 (or over $45 \%$ ) also required such study. This figure befitted the very nature of Type 1.0, of course, so it was not unexpected.

Literary history/theory and literary criticism represented the more-advanced course offerings among the purposeful sampling of 20 English curricula. Of its 11 Type 1.0 programs, 2 offered courses in literary history and/or literary theory at the 400 level; 2 required courses in literary criticism at the 300 level; 3 required literary criticism at the 400 level; and 3 offered literary criticism at the 400 level. 
It should be noted that I categorized these literary history/theory and literary criticism courses primarily by their course descriptions. As these subjects overlap in content, I assigned categories according to their particular emphasis-the history of literary theory or the critical methodologies as interpretative tools. Thus, on occasion, a title with the words "literary theory" actually represented "literary criticism." An example of this appears clearly on Table 24 with the Wheaton College English curriculum which described "ENG 434 Modern Literary Theory" as "[a]n introduction to the most influential modern theories [about interpreting literature] ... with particular emphasis on deconstruction, Marxism, and feminism" (Catalog of Wheaton College, 2001-2002, 2001, p. 79). Despite their occasionally misleading titles, these courses were required among 5 of the 11 Type 1.0 curricula (or, over $45 \%$ ).

Additional evidence of the importance of literary history/theory and literary criticism within the purposeful sampling of 20 curricula appeared with the Type 1.5 Primarily Literature category. Of the four Type 1.5 curricula, as shown on Table 25, three curricula offered courses in these two subjects. Two of those three each required such a course; one required literary criticism at the 300 level; the other required literary history/literary theory at the 400 level. Another curriculum offered literary criticism as a 300-level elective course.

While Type 2.0 curricula still tended to include study among literary history/ literary theory, they registered lower percentages than the previous types; only three of the five curricula, for $60 \%$, had such courses, and only one of those three required the study (as shown on Table 26). It did so at the 300 level. These figures reflected the nature 
Table 24

Literary History/Theory and Literary Criticism Among Type 1.0 English Curricula $(N=11)$

\begin{tabular}{lll}
\hline & Literary History/Theory & Literary Criticism \\
CCCU Member & Instruction Level & Instruction Level \\
(Catalog Years) & $\mathrm{R}=$ Requirement & $\mathrm{R}=$ Requirement
\end{tabular}

Colorado Christian U. (2001-2002)

$\mathrm{x} 400 \mathrm{R}$

Dallas Baptist U.

(2002-2004)

Eastern Mennonite U.

(2001-2002)

Gordon C.

$\mathrm{x} 400$

(2001-2002)

Houghton C.

$\mathrm{x} 400 \mathrm{R}$

(2001-2002)

Lee U.

$\mathrm{x} 300 \mathrm{R}$

(2001-2002)

Northwest Nazarene. U x $300 \mathrm{R}$ (2001-2002)

Palm Beach Atlantic C. (2001-2002)

Redeemer University C. $\quad x 400$

(2000-2002)

Westmont C.

(2002-2003)

Wheaton C. (IL)

$x 400^{c}$

$\times 400^{d}$

(2001-2002)

\footnotetext{
${ }^{a}$ ENG 4543 Modern Literary Theory.

${ }^{b}$ ENG 4973 Senior Seminar in Methods of Literary Criticism.

${ }^{c}$ ENGL 435 History of Literary Criticism.

d ENGL 434 Modern Literary Theory.
} 
Table 25

Literary History/Theory and Literary Criticism Among Type 1.5 English Curricula $(N=4)$

$\begin{array}{lll}\text { CCCU Member } & \text { Literary History/ } & \text { Literary Criticism } \\ \text { (Catalog Years) } & \text { Literary Theory } & \mathrm{R}=\text { Requirement } \\ & \mathrm{R}=\text { Requirement } & \end{array}$

Dordt C.

x 300

(2001-2002)

Evangel U.

(2000-2002)

Malone C.

$\mathrm{X} 400 \mathrm{R}$

(2001-2002)

Oklahoma Christian U.

x $300 \mathrm{R}$

(2001-2002)

Table 26

Literary History/Theory and Literary Criticism Among Type 2.0 English Curricula $(N=5)$

\begin{tabular}{llr}
\hline CCCU Member & Literary History/ & \multicolumn{1}{c}{ Literary Criticism } \\
(Catalog Years) & Literary Theory & $\mathrm{R}=$ Requirement \\
& $\mathrm{R}=$ Requirement &
\end{tabular}

Bethel C.

x $300 R$

(2001-2002)

Goshen C.

(2001-2003)

King C.

x 300

(2001-2002)

Seattle Pacific U.

$\mathrm{x} 400$

(2001-2002)

Simpson C.

(2001-2002) 
of the Type 2.0 English curriculum: Stewart (1989) named this category "More Flexible," because it represented a curriculum wherein literature played a less monolithic role than in Types 1.0 and 1.5. Nevertheless, all three types of English curricula included among the purposeful sampling of $20 \mathrm{CCCU}$ curricula shared the second strength -the inclusion of literary history/literary theory and/or literary criticism.

The third strength of the CCCU English curricula evident within the purposeful sampling appeared in the use of a senior-level capstone course. Offered to encourage students in the synthesis and evaluation of their undergraduate studies, this culminating course appeared within 10 of the 20 curricula. Tables $27-30$ indicate this common inclusion, showing that the seminar/capstone course represented a regular feature of Type 1.0 Straight Literature curricula. Eleven such courses occurred within the purposeful sampling, and five of the 11 offered such a course. Four required this capstone course, commonly entitled "Senior Seminar."

Variously subtitled, the senior seminars or capstone courses indicated through their full course descriptions that they shared four emphases among the types of English curricula. (See Table 27.) From most to least frequent, these emphases included the (a) integration of faith and learning, cited by 6 (or $30 \%$ ) of the 20 selected curricula, (b) employment of critical thinking, cited explicitly by 3 (or 15\%), (c) research, cited explicitly by 3 (or 15\%) and implied by 2 other curricula through a senior project/paper presentation, and (d) English discipline/studies issues and their analysis, cited by two (or $10 \%)$. Implicit among all these seminars, of course, was the need for critical, analytical, and reflective thinking. 
Table 27

Seminar/Capstone Courses Among Type 1.0 English Curricula $(N=11)$

\begin{tabular}{|c|c|c|c|c|}
\hline $\begin{array}{l}\text { CCCU Member } \\
\text { (Catalog Years) }\end{array}$ & $\begin{array}{l}\text { Course Title } \\
\text { Level (Hours) }\end{array}$ & Required & Elective & $\begin{array}{l}\text { Emphasis/ } \\
\text { Emphases }\end{array}$ \\
\hline
\end{tabular}

Colorado C.U.

(2001-2002)

Dallas Baptist U. Seminar in English

(2002-2004)

300 (3)

X Analysis

of issues

Eastern Mennonite U.

(2001-2002)

Gordon C.

(2001-2002)

Houghton C.

(2001-2002)

Senior Seminar:

Problems of Literary

$\mathrm{x}$

Research

Study 400 (3)

Integration

of faith \&

learning

Lee U.

(2001-2002)

English in Christian

$\mathbf{x}$

Integration

Perspective 400 (3)

of faith \&

learning

Northwest

Senior Seminar

$\mathrm{x}$

Independent

Nazarene U.

(2001-2002)

400 (1)

critical thinking

Senior project

Palm Beach At. U.

Senior Seminar

$\mathrm{x}$

Research \&

Methods of

criticism

Literary Criticism

Ethics of

400 (3)

English

Redeemer U.

(2000-2002)

Westmont C.

(2002-2003)

Wheaton C.

(2001-2002)

Senior Seminar

$\mathrm{X}$

Critical thinking

400 (3)

Integration 
The capstone course, as noted before, appeared in more than half of the Type 1.0 Straight Literature curricula within the purposeful sampling: 6 of the 11, or nearly $55 \%$, provided such integrative courses. This finding seemed understandable, as this type of major tended to perpetuate the traditional canon of literature with its inclusion of authors writing within various Christianity-related eras: for example, Chaucer writing amid late medieval Europe on the eve of reform or Milton writing just after the English Civil War.

What did surprise me, however, was the low incidence of seminar or capstone courses found among Type 1.5 Primarily Literature curricula. Only one of four such curricula, as indicated on Table 28 , offered such a senior seminar oriented to evaluation and integration of the major studies. Other seminars were offered, but they proved subject-specific such as a seminar in literature. I thought the low number of Type 1.5 curricula, four within the sampling of 20 (or $20 \%$ ), may have skewed this finding. I did not, however, run a check of capstone/seminar usage among Type 2.0 (shown on Table 29).

Thus, I supplemented Table 25 with a random sampling of Type 1.5 English curricula taken from those programs not included in the purposeful sampling. Taking every fourth curricula among those 25 , I reviewed Type 1.5 Primarily Literature curricula excluded from the purposeful sampling of 20 to find these results: Calvin College had a required senior seminar "designed to nurture Christian reflection on issues related to language and literature" (Calvin College Catalog 2001-2002, 2001, p. 134). The other Type 1.5 curricula chosen for this check included Fresno Pacific University, John Brown University, Malone College, Southern Wesleyan University, and Warner Southern College. Not one of these English curricula offered a capstone course. That finding 
Table 28

Seminar/Capstone Courses Among Type 1.5 English Curricula $(N=4)$

$\begin{array}{lllll}\text { CCCU Member } & \text { Course Title Required } & \text { Elective } & \text { Emphasis/ } & \text { None } \\ \text { (Catalog Years) } & \text { Level (Hours) } & & \text { Emphases } & \text { Offered }\end{array}$

Dordt C.

(2001-2002)

Evangel U.

(2000-2002)

Malone C.

(2001-2002)

Oklahoma C.U.

Senior Seminar

(2001-2002)

$400(3)$

$\mathrm{X}$

Critical thinking

Research

furthered the evidence that Type 1.5 curricula, in contrast to Type 1.0, gave less emphasis to students' evaluating and integrating their undergraduate studies.

Capstone courses among Type 2.0 More Flexible English curricula within the purposeful sampling emphasized the integration of faith and learning, which one school narrowed to the integration of faith and the English discipline. Table 29 presents the results for the five Type 2.0 More Flexible majors among the selected 20 curricula.

Notably, three of the five (or 60\%) required the capstone course, entitled for each of the three "Senior Seminar." This seemed a reasonable requirement for curricula with as much variation as this type possessed. Students pursuing varied emphases within a Type 2.0 major would benefit by seminars challenging their critical thinking and their Christian belief. 
Table 29

Seminar/Capstone Courses Among Type 2.0 English Curricula $(N=5)$

\begin{tabular}{|c|c|c|c|c|}
\hline $\begin{array}{l}\text { CCCU Member } \\
\text { (Catalog Years) }\end{array}$ & $\begin{array}{l}\text { Course Title } \\
\text { Level (Hours) }\end{array}$ & Required & Elective & $\begin{array}{l}\text { Emphasis/ } \\
\text { Emphases }\end{array}$ \\
\hline
\end{tabular}

$\begin{array}{llll}\begin{array}{l}\text { Bethel C. (MN) } \\ (2001-2002)\end{array} & \begin{array}{l}\text { Senior Seminar: } \\ \text { The Writer as } \\ 400(4)\end{array} & x & \begin{array}{l}\text { Integration of } \\ \text { faith and } \\ \text { learning }\end{array} \\ \begin{array}{l}\text { Goshen C. } \\ (2001-2003)\end{array} & \begin{array}{l}\text { Senior Seminar } \\ 400(1)\end{array} & x & \begin{array}{l}\text { English issues } \\ \text { Integration of } \\ \text { faith and } \\ \text { learning }\end{array} \\ & & \text { a }\end{array}$

(2001-2002)

Seattle Pacific U. Senior Capstone $\quad x \quad$ Faith and the

(2001-2002) Seminar 400(5) English

discipline

Simpson C.

$\mathrm{x}$ (2001-2002)

In summary, among the purposeful sampling of 20 CCCU English curricula, all of which represented to some degree literature programs, three content strengths became evident: (a) British/English and American literatures dominated Types 1.0, 1.5, and 2.0 curricula; (b) literary history/theory and literary criticism served as a staple, advanced course among all three types of curricula to prepare students for graduate studies; and (c) seminar/ capstone course among Type 1.0 and Type 2.0 curricula became a regular feature through which students evaluated their studies and integrated them with the Christian faith. 
In addition to the three content strengths, one particular opportunity strength also characterized the purposeful sampling of 20 CCCU English curricula: the career-oriented internship and practicum. Thirteen or $65 \%$ of the selected curricula provided internship and/or practicum experience; understandably, as the three curriculum types among the sampling became less dominated by literature, they appeared more likely to offer courses oriented to non-academic careers (as shown by Tables $31-32$ ).

Table 30 indicates that 5 of 11 (or nearly 46\%) of Type 1.0 Straight Literature curricula listed internships and/or practicum courses. Three of four Type 1.5 Primarily Literature, or $75 \%$ (as shown on Table 31), included those skill and career-related courses. Table 32 indicates that every Type 2.0 More Flexible English curricula $(N=5)$ among the sampling offered internships and/or practicum courses.

The common requirement among the Type 1.0 curricula for enrollment in their internship and/or practicum courses was that enrollees held junior or senior standing. Other expectations among the curricula were that enrollees performed well in their previous English courses, and that they served their internships away from campus. Placements occurred within the communication and journalism fields, as well as in professional writing and literature. Practicum experiences, however, were more likely to be on campus and to involve tutoring in writing.

Type 1.5 Primarily Literature curricula included among the purposeful sampling of 20 appeared more likely than Type 1.0 Straight Literature plans to offer internship and practicum opportunities-especially the latter. Three of the four Type 1.5 curricula, or $75 \%$, provided practicum courses; two of the four listed these courses at the sophomore level (as shown on Table 31). Type 2.0 curricula did not offer skill and career-related 
Table 30

Internships and Practicum Courses Among Type 1.0 English Curriculum (N=11)

\begin{tabular}{|c|c|c|c|}
\hline $\begin{array}{l}\text { CCCU Member } \\
\text { (Catalog Years) }\end{array}$ & $\begin{array}{l}\text { Internship (Levels) } \\
\text { (Semester Hours) } \\
\text { NA = Not Available }\end{array}$ & $\begin{array}{l}\text { Practicum (Levels) } \\
\text { (Semester Hours) } \\
\mathrm{T}=\text { Tutoring } \\
\mathrm{NA}=\text { Not Available }\end{array}$ & Notations Made \\
\hline $\begin{array}{l}\text { Colorado Christ. U. } \\
(2001-2002)\end{array}$ & NA & NA & \\
\hline $\begin{array}{l}\text { Dallas Baptist U. } \\
(2002-2004)\end{array}$ & NA & NA & \\
\hline $\begin{array}{l}\text { Eastern Mennonite U. } \\
(2001-2002)\end{array}$ & NA & $\mathrm{NA}$ & \\
\hline $\begin{array}{l}\text { Gordon College } \\
(2001-2002)\end{array}$ & $X(400)(2-4)$ & X T (300) (2) & $\begin{array}{l}\text { 1) In journalism } \\
\text { 2) Cross-listed with } \\
\text { communication }\end{array}$ \\
\hline $\begin{array}{l}\text { Houghton College } \\
(2001-2002)\end{array}$ & $X(300)(3)$ & & 1) Summer listing \\
\hline $\begin{array}{l}\text { Lee University } \\
(2001-2002)\end{array}$ & NA & & \\
\hline $\begin{array}{l}\text { Northwest Naz. U. } \\
(2001-2002)\end{array}$ & $X(300)(3)$ & & $\begin{array}{l}\text { 1) In professional } \\
\text { writing } \\
\text { 2) } 100 \text { hours minimum } \\
\text { 3) Professional } \\
\text { situation \& location }\end{array}$ \\
\hline
\end{tabular}

Palm Beach Atl. C. NA

(2001-2002)

Redeemer Univ. C. NA

(2000-2002)

Westmont College NA

(2002-2003)

Wheaton C. (IL) $\quad \mathrm{X}(400)^{\mathrm{a}}$

1) In literature

(2001-2002)

2) In writing (separate

from Engl. major)

${ }^{\mathrm{a}}$ Hours were not evident. 
Table 31

Internship and Practicum Courses Among Type 1.5 Curricula $(N=4)$

\begin{tabular}{|c|c|c|c|}
\hline $\begin{array}{l}\text { CCCU Member } \\
\text { (Catalog Years) }\end{array}$ & $\begin{array}{l}\text { Internship (Levels) } \\
\text { (Semester Hours) } \\
\text { NA = Not Available }\end{array}$ & $\begin{array}{l}\text { Practicum (Levels) } \\
\text { (Semester Hours) } \\
\mathrm{T}=\text { Tutoring } \\
\mathrm{NA}=\text { Not Available }\end{array}$ & Notations Made \\
\hline $\begin{array}{l}\text { Dordt College } \\
(2001-2002)\end{array}$ & & $X(200)(1-3)$ & $\begin{array}{l}\text { 1) Service learning } \\
\text { courses listed at } \\
200 \text { level } \\
\text { 2) Repeatable } \\
\text { 3) Community setting }\end{array}$ \\
\hline $\begin{array}{l}\text { Evangel U. } \\
(2000-2002)\end{array}$ & $X(400)(1-3)$ & $X(200)(1-3)$ & \\
\hline $\begin{array}{l}\text { Malone College } \\
(2001-2002)\end{array}$ & NA & & \\
\hline $\begin{array}{l}\text { Oklahoma C.U. } \\
(2001-2002)\end{array}$ & & $X(400)^{a}$ & $\begin{array}{l}\text { 1) In writing/research/ } \\
\text { editing } \\
\text { 2) With publisher of } \\
\text { periodical }\end{array}$ \\
\hline
\end{tabular}

${ }^{\mathrm{a}}$ Hours were not evident.

courses below the junior level (as shown on Table 32). This emphasis on the practicum appeared to be the one commonality among the Type 1.5 curricula.

Table 32 shows that every Type 2.0 More Flexible English curriculum among the purposeful sampling included internship and practicum courses, and three of the five listed these courses at the senior level only. Type 2.0 programs shared the commonality of having their internships cover a broader spectrum of English studies; these included 
Table 32

Internship and Practicum Courses Among Type 2.0 English Curricula $(N=5)$

\begin{tabular}{|c|c|c|c|}
\hline $\begin{array}{l}\text { CCCU Member } \\
\text { Catalog Years }\end{array}$ & $\begin{array}{l}\text { Internship (Levels) } \\
\text { (Semester Hours) } \\
\text { NA = Not Available }\end{array}$ & $\begin{array}{l}\text { Practicum (Levels) } \\
\text { (Semester Hours) } \\
\mathrm{T}=\text { Tutoring } \\
\text { NA = Not Available }\end{array}$ & Notations Made \\
\hline $\begin{array}{l}\text { Bethel College } \\
(2001-2002)\end{array}$ & $X(400)(4)$ & & $\begin{array}{l}\text { 1) In writing } \\
\text { 2) Off-campus }\end{array}$ \\
\hline $\begin{array}{l}\text { Goshen College } \\
(2001-2003)\end{array}$ & $X(300)(3)$ & & 1) In TESOL \\
\hline $\begin{array}{l}\text { King College } \\
(2001-2002)\end{array}$ & $\begin{array}{l}X(300 / 0)^{a}(4) \\
X(300 / 0)^{a}(4)\end{array}$ & & $\begin{array}{l}\text { 1) Minimum GPA } 2.5 \\
\text { required } \\
\text { 2) Various situations } \\
\text { and locations }\end{array}$ \\
\hline $\begin{array}{l}\text { Seattle Pacific U. } \\
(2001-2002)\end{array}$ & $\begin{array}{l}X(400)(1-5) \\
X(400)(1-5)\end{array}$ & $X(400)(1-3)$ & $\begin{array}{l}\text { 1) Internships cross- } \\
\text { listed with } \\
\text { journalism courses } \\
\text { 2) Various situations } \\
\text { and locations for } \\
\text { internships } \\
\text { 3) Practicum in Engl. } \\
\text { in tutoring or being } \\
\text { department readers }\end{array}$ \\
\hline $\begin{array}{l}\text { Simpson College } \\
(2001-2002)\end{array}$ & & $\begin{array}{l}X(370 / 0)(1-3) \\
X(200 / 0)(2)^{b} \\
X(200 / 0)(2)^{c} \\
X(200 / 0)(1)^{d} \\
X(300 / 0)(2)^{b} \\
X(300 / 0)(2)^{c} \\
X(300 / 0)(1)^{d}\end{array}$ & $\begin{array}{l}\text { 1) Practicum in } \\
\text { writing } \\
\text { 2) Practicum } \\
\text { involved } \\
\text { tutoring and } \\
\text { managing writing } \\
\text { center }\end{array}$ \\
\hline
\end{tabular}

${ }^{a}$ Senior level course.

" On college newspaper staff, a laboratory experience termed "practicum."

" On college yearbook staff, a laboratory experience termed "practicum."

"In drama, a laboratory experience termed "practicum." 
not only journalism, literature, and writing, but also Teaching English as a Second Language (TESOL).

As Types 1.0 and 1.5 curricula did, Type 2.0 curricula also required internships to be served off-campus. Their practicum courses, too, were likely to consist of on-campus experiences, including those at Simpson College whose practicum course listings represented what other colleges usually listed as 200-level laboratories or workshops. More commonly, the practicum involved tutoring other students in writing or grading essays under professional guidance.

In summary to question 1g: Among the several weaknesses and strengths which characterized the purposeful sampling of $20 \mathrm{CCCU}$ English curricula, the most frequent and most significant weakness was the lack of stated goals or aims, an omission that characterized $45 \%$ of the sampling. Other weaknesses in descending order included its (a) lack of attention to writing, (b) imbalance of course offerings, with many at the 300 level and few at the 400 level, (c) lack of emphasis on linguistics, (d) lack of attention to composition/rhetoric, (e) de-emphasis on non-Western, multicultural, and minority literatures, (f) lack of practical, career-related opportunities, and (g) proliferation of elective courses.

The fundamental strength of the CCCU English curricula within the purposeful sampling lay in their literary character. In this, they reflected what Stewart (1989) found in the first categorization of non-CCCU English majors: literature ruled the English curricula. In this, they also reflected what $\operatorname{Graff}(1987,1990)$ described as a literaturebased major with a literary core, with vestiges of historical coverage in courses such as "Romanticism," and with proliferating electives. 
Apart from this dominance of literature, several other strengths were evident among the purposeful sampling of 20; three represented curricular content strengths and one represented an opportunity strength. The four strengths included the following notable facts:

1. British/English and American literatures, which dominated the curricula, had the greatest ranges of required and elective literature courses among Types 1.0,1.5, and 2.0 curricula.

2. A literary criticism or a literary history/theory course was offered by 14 of the 20 curricula (or, $70 \%$ ). Among 8 of the 20 (or, $40 \%$ ), this course represented a requirement or an option to meet a requirement. Among Type 1.0 English curricula, this course was required by 5 of 11 majors (or $45 \%$ ).

3. A capstone/senior seminar represented a staple course - often a requirementto encourage students to evaluate their learning and to integrate it with the Christian faith. This course appeared in 10 of 20 (or 50\%) of the curricula. Eight (40\%) required this course, and six (30\%) stressed the relation of literature and Christian faith.

4. Internship and practicum courses provided career-related skills and experiences among $60 \%(N=20)$ of the sampling. While this latter strength looked most pronounced among the Type 2.0 More Flexible curricula, all three English major types provided opportunities for career preparation.

Also apparent were two developments, neither strengths nor weaknesses, but notable situations: (a) an increasing emphasis on writing developed between 1997 and 2002, and (b) a career option in Teaching English as a Second Language (TESOL), or some variation of this program, became available among 10 of the 20 schools. 


\section{Evidence of Christian Thought}

Research question 2.0 asked, What evidence of Christian thought or influence appeared among the individual CCCU English major curricula, and, thus, within the aggregate curriculum?

As this question prompted my entire study, I began to address it during my first close reading of the curricula; I recorded observations on the First Look cards about course offerings which included overtly Christian content. I noted course titles, numbers, credits, and brief comments such as "elective" and "emphasis is on "(e.g., C. S. Lewis). Then rereading the curricula for the Claims cards, I rerecorded any reference made to Christianity; the final categories on the Claims card allowed not only for references to career preparation, including the ministry, but to the integration of faith and learning. The final item "Other" on that card allowed for any Christian reference, goal, and/or objective. After the Claims cards were completed, I then applied the Content Categories and Emphases cards to the curricula; these cards also allowed for any reference to Christian thought or influence under "Other." As I reread closely, I highlighted all explicit references to Christian thought, and in another color highlighted implicit evidence such as a course about Chaucer, or a survey including Hawthorne.

Finally, I constructed a table to record any overt reference to Christianity among the 98 CCCU English curricula offering the undergraduate English major. (Three of the 101 schools did not.) This table recorded the members' names, catalog or bulletin dates, and any reference to Christian thought or influence occurring within their introductory statements (where extant) and within their course descriptions. Under the introductory statements category, I recorded pertinent excerpts to give context to any reference; 
further, I identified each excerpt as simply part of the introductory statement; or as part of the mission statement, goal, or objective; or as something "other" which I identified when possible.

Under the course descriptions column, I recorded each course possessing any Christian reference, and included its course number, credit, title, excerpt, and as needed "required." Courses representing eras, authors, and/or debates dominated by Christian ideas (e.g., Chaucer or Milton) were included whether or not they made any explicitly Christian references. Courses treating authors associated with unorthodox Christian ideas, such as Blake and Dickinson, also were listed. If courses referred to literary schools or movements which involved Christian conceits, emblems, and theology, such as the Metaphysicals (e.g., John Donne or George Herbert) or Puritanism, of course they were included.

I did not, however, separate implicit from explicit evidence as this complicated the table unnecessarily. Rather, I combined both under the collective term "evidence" (as shown in Appendix D.) Separating implicit evidence seemed unnecessary, too, for English faculty would recognize that such authors as Chaucer, Milton, Hawthorne, Hopkins, and T. S. Eliot had written within various Christian eras and traditions. Occasionally, I did include brief comments to clarify.

Overt evidence of Christian thought represented four categories of courses: those focused on (a) biblical content, (b) integrated Christian and English content, (c) Christian authors through the $19^{\text {th }}$ century, and (d) Christian authors during the $20^{\text {th }}$ century. Their discussion immediately follows (below). 


\section{Biblical Content}

The first category, biblical content, included courses in which the Holy Bible served as the primary text studied for its literary qualities, especially its forms and genres. Among the purposeful sampling, courses given to biblical content appeared among five curricula, four of which represented Type 1.0 Straight Literature majors. Lee University offered the most detailed course description of the four: "EN 325 The Bible as Literature" represented "An introduction to the literary forms of the Bible, such as short stories, epics, drama, poetry, proverbs, the Gospels, parables, epistles, satire and visionary literature" (Lee University Undergraduate Catalog, 2001-2002, 2001, p. 169). Northwest Nazarene University and Wheaton College (IL) did not provide detailed descriptions of their comparable courses, but referred respectively to "literary qualities" and "literary forms and meanings" (Catalog of Wheaton College, 2001-2002, 2001, p. 79; Northwest Nazarene University Undergraduate Catalog, 2001-2002, 2001, p. 212).

Gordon College offered a more specific type of biblical literature course titled "Biblical Narrative" (EN 360), whose description emphasized the Bible's "themes and characters" and their "[integration] within [its] overarching and unified plot" (Gordon College Academic Catalog, 2001-2002, 2001, p. 102). This course was not cross-listed with any Biblical and Theological Studies courses at Gordon, as I thought it might have been since its content suggested narrative theology; rather, it stood alone in Gordon's English curriculum, and alone among the other Type 1.0 Bible-as-literature courses emphasizing forms and genres.

This emphasis on form and genre appeared in the one Type 1.5 Primarily Literature curriculum which offered a comparable course: Evangel University entitled its 
study "Literary Forms of the Bible" (EN 335), and stressed that approach in its course description (Evangel University Catalog, 2000-2002, 2000, p. 117). Notably, no Type 2.0 curriculum among the purposeful sampling offered such a course. Studies in the English Bible as literature belonged primarily to Type 1.0 (shown by Table 33). The Type 1.0 Straight Literature English major lent itself to this course, which was genuinely literary in nature; its religious or historical content did not eclipse its literary character (McMillan, 1993, p. 96).

\section{Integrated Content}

The second type of overt Christian evidence in the purposeful sampling represented integrated content of Christian thought and English studies. Seven of the 20 curricula had such courses whose titles usually suggested the integration of faith with literature and writing. "ENG 495 English in Christian Perspective" at Lee University exemplified that type of an integrated study; it also offered a detailed description: "Through readings, oral discussion, a journal, and a paper, English majors are assisted in the integration of the various facets of the major in relation to fundamental disciplinary concepts and [major] philosophical, theological, and ethical concepts, guided by Christian perceptions of truth" (Lee University Undergraduate Catalog, 2001-2002,pp. 171-172). The word "disciplinary" logically reflected Lee's offering a Type 1.0 curriculum structured in the traditional paradigm wherein literature ruled.

All three types of English curricula, however, evidenced overtly Christian thought (as shown on Table 33). Evangel University, whose Type 1.5 curriculum stressed literature but to a lesser degree than did Type 1.0 curricula, offered an interdisciplinary course entitled "ENGL 440 Theology and Christian Literature," and offered it in concert Table 33 


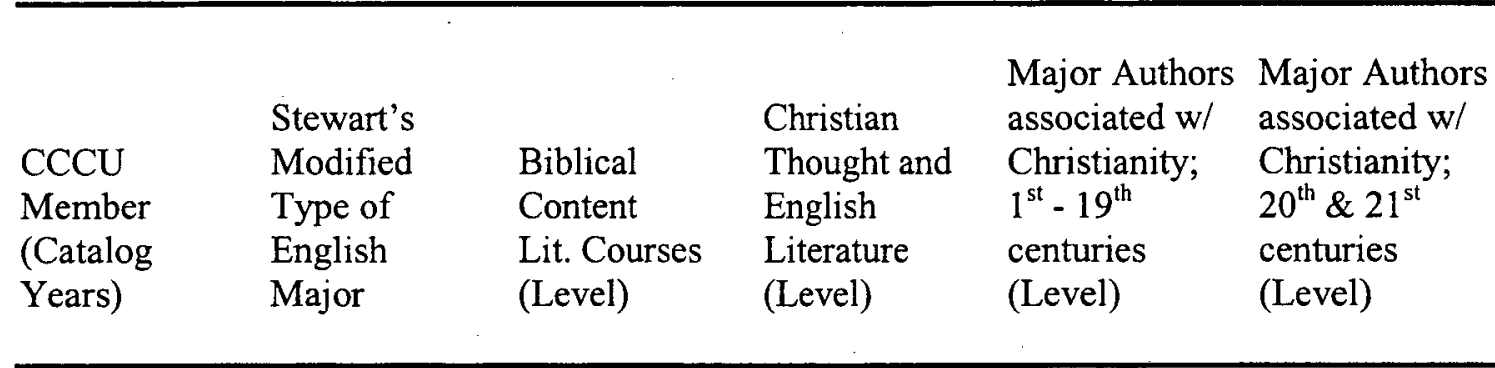

$\begin{array}{ll}\text { Bethel C. } & 2.0 \text { More } \\ (\mathrm{MN}) & \text { Flexible } \\ (2001-2002) & \end{array}$

Colorado

Ch. U.

1.0 Straight

(2001-2002)

Dallas 1.0 Straight

Baptist U. Literature

(2002-2004)

Dordt C. $\quad 1.5$ Primarily

(2001-2002) Literature

Evangel U. $\quad 1.5$ Primarily

(2000-2002) Literature

Eastern 1.0 Straight

Mennonite U. Literature

(2001-2003)

Goshen C. 2.0 More

(2001-2003) Flexible

Gordon C. 1.0 Straight Biblical

(2001-2002) Literature Narrative (300)

Houghton C. 1.0 Straight

(2001-2002) Literature
Forms of the

Bible (300)

$\begin{array}{lll}\text { Senior Sem.: } & \text { Chaucer } & \text { Christian } \\ \text { The Writer } & (300) & \text { Writers }^{\mathrm{a}} \\ \text { as Believer } & \text { Milton } & (300) \\ (400) & (300) & \end{array}$

Milton and

Bunyan

(400)

C.S. Lewis
$(400)$

Theology \& Milton (300)

Christian

Lit. (400)
Chaucer (400)
Milton (300)

Senior Sem.:

Problems of

Literary

Study (400)
Special Topics

in Literature

(300) (e.g.,

Oxford

Christians)

Table 33-Continued. 


\begin{tabular}{|c|c|c|c|c|c|}
\hline & & & & Major Authors & Major Author \\
\hline CCCU & $\begin{array}{l}\text { Stewart's } \\
\text { Modified }\end{array}$ & Biblical & $\begin{array}{l}\text { Christian } \\
\text { Thought and }\end{array}$ & $\begin{array}{l}\text { associated w/ } \\
\text { Christianity; }\end{array}$ & $\begin{array}{l}\text { associated w/ } \\
\text { Christianity; }\end{array}$ \\
\hline Member & Type of & Content & English & $1^{\text {st }}-19^{\text {th }}$ & $20^{\text {th }} \& 21^{\text {st }}$ \\
\hline (Catalog & English & Lit. Courses & Literature & centuries & centuries \\
\hline Years) & Major & (Level) & (Level) & (Level) & (Level) \\
\hline
\end{tabular}

$\begin{array}{ll}\text { King C. } & 2.0 \text { More } \\ (2001-2002) & \text { Flexible }\end{array}$

Lee U. (2001-2002)

Malone C. (2001-2002)

Northwest

Nazarene U. (2001-2002)

Palm Beach

Atlantic U. Literature

(2001-2002)

Redeemer

University C.

(2000-2002)

Seattle 2.0 More

Pacific U. Flexible

(2001-2002)

\subsection{Straight \\ Literature}

\subsection{Primarily}

Literature 1.0 Straight

1.0 Straight

1.0 Straight

Literature

Literature of the Bible

(300)

\section{English in}

Christian

Persp. (400)
Topics in

Religion and

Lit. (200)

$\begin{array}{ll}\text { Augustine } & \text { Literary } \\ \text { (200) } & \text { Passages (200) } \\ \text { Chaucer (300) } & \text { (Oxford } \\ \text { Milton (300) } & \text { Christians) }\end{array}$

Chaucer (400)

Milton (400)
Chaucer (400)

Milton (400)
Senior Cap.

Seminar (400)
Best of C.S. Lewis (400)

Directed readings in the C.S. Lewis Circle (400)

Simpson C. 2.0 More

(2001-2002) Flexible

Westmont C. 1.0 Straight (2002-2003) Literature

Chaucer $^{\mathrm{a}}$

Milton $^{a}$

Table 33-Continued. 


\begin{tabular}{|c|c|c|c|c|c|}
\hline $\begin{array}{l}\text { CCCU } \\
\text { Member } \\
\text { (Catalog } \\
\text { Years) }\end{array}$ & $\begin{array}{l}\text { Stewart's } \\
\text { Modified } \\
\text { Type of } \\
\text { English } \\
\text { Major }\end{array}$ & $\begin{array}{l}\text { Biblical } \\
\text { Content } \\
\text { Lit. Courses } \\
\text { (Level) }\end{array}$ & $\begin{array}{l}\text { Christian } \\
\text { Thought and } \\
\text { English } \\
\text { Literature } \\
\text { (Level) }\end{array}$ & $\begin{array}{l}\text { Major Authors } \\
\text { associated w/ } \\
\text { Christianity; } \\
1^{\text {st }}-19^{\text {th }} \\
\text { centuries } \\
\text { (Level) }\end{array}$ & $\begin{array}{l}\text { Major Authors } \\
\text { associated w/ } \\
\text { Christianity; } \\
20^{\text {th }} \& 21^{\text {st }} \\
\text { centuries } \\
\text { (Level) }\end{array}$ \\
\hline $\begin{array}{l}\text { Wheaton C. } \\
(2001-2002)\end{array}$ & $\begin{array}{l}\text { 1.0 Straight } \\
\text { Literature }\end{array}$ & $\begin{array}{l}\text { Literature of } \\
\text { the Bible } \\
(300)\end{array}$ & $\begin{array}{l}\text { Senior } \\
\text { Seminar } \\
(400)\end{array}$ & $\begin{array}{l}\text { Chaucer } \\
(300) \\
\text { Milton }(300) \\
\text { Johnson } \\
(300)\end{array}$ & $\begin{array}{l}\text { Modern } \\
\text { Mythology } \\
(400) \text { (C.S. } \\
\text { Lewis and } \\
\text { associated } \\
\text { writers) }\end{array}$ \\
\hline
\end{tabular}

${ }^{\mathrm{a}} 150$ number represents junior level instruction

with Evangel's Department of Biblical Studies and Philosophy (Evangel University Catalog, 2000-2002, 2000, pp. 65 \& 118). Described as “[an] integrative course," it provided a study of "theology through literature" through "major Christian writers of the Western world" (p. 65). Notably, its course description listed "a special emphasis on the thought and writings of C. S. Lewis" (p. 65).

Another type of curricula, the 2.0 More Flexible type, also provided an example of overt evidence: Seattle Pacific University offered its "ENG 4225 Senior Capstone Seminar" for students to integrate their "learning in [the] English major" and to "[reflect] upon the relationship between faith and the discipline of literary studies" (Seattle Pacific University Undergraduate Catalog, 2001-2002, 2001, p. 131). "Examples of the kind of text to be considered" included Christian-oriented works such as Paradise Lost, as well as debunking works such as Middlemarch. 
This capstone course typified the integrative Christian thought courses among the purposeful sampling. Four of the seven courses (representing seven curricula) among the 20 were capstone or senior seminar courses, and two others shared their integrative nature if not their titles (i.e., "Theology and Christian Literature" and "English in Christian Perspective"). The seven, regardless of major type, also stressed the integration of faith and literature. Even "EN 499 Senior Seminar: "The Writer as Believer" at Bethel College (MN) emphasized literary texts rather than, for instance, the production of texts.

If composition/writing gave little explicit evidence to Christian ideas, linguistics gave none. No course among the purposeful sampling offered linguistics study which included concern for any Christian concerns such as, for instance, the interpretation of biblical concepts into newly recorded languages. Only one curriculum appeared to allow the possibility of such concerns: Oklahoma Christian University listed two courses, “Intercultural Communication I and II," giving "special attention to problems faced by language instructors" in "[communicating] across cultural boundaries" (Oklahoma University Catalog, 2001, p. 142). No overt mention of Christian concerns, however, appeared in these descriptions.

Nor did courses in literary theory and literary criticism show particular concern for Christian thought. I had hoped to find strong evidence of Christianity among those courses, at least, since St. Augustine's On Christian Doctrine represented a seminal text for both studies. Instead, I found only two citations of Christianity and one of Augustine, himself. Bethel College (MN) in its "ENL 360 Literary Theory and Interpretation" placed "[emphasis on] ethical and Christian critiques" (Bethel College Catalog, 2001-2002, 2001, p. 123). Dordt College, through its "English 333 History and Theory of Literary 
Criticism," offered an "[analysis of] major works of literary criticism and theory of criticism from Plato [to] Eliot" and beyond to contemporary works, "with the aim of formulating clearer Christian theories of literature" (Dordt College 2001-2002 Catalog, 2001, p. 137). Wheaton College (IL), in its "ENGL 435 History of Literary Criticism," listed Augustine and Dante among secular critics such as "Arnold, Nietzsche, and Marx" (Catalog of Wheaton College, 2001-2002, 2001, p. 79). As the names Augustine and Dante signaled Christian writings, I counted this reference as one of the few explicit references to Christianity among the literary criticism courses within the sampling.

\section{Major Authors Associated With Christianity Through the $19^{\text {th }}$ Century}

The third category of explicit evidence of Christian thought within the sampling appeared through the courses given to major authors associated with Christian thought from the $1^{\text {st }}$ through the $19^{\text {th }}$ century. By "associated with" I meant those whose texts have been dominated by Christian ideas, and whose texts have been subject to criticism strongly oriented to Christian ideas. Thus, Milton represented a major writer whose major works cannot be interpreted apart from Christian thought, but Shakespeare (with only one sonnet and one drama inseparable from Christian thought) does not, by my definition, represent an author associated with Christianity. Other researchers, however, may disagree, but I base his exclusion here on Grady (2001, pp. 265 - 278) and White's (2001, pp. 279 -295) histories of Shakespearean criticism in the Cambridge Companion to Shakespeare. Other exclusions were based on similar reasoning and resources.

The purposeful sampling showed that the most often cited authors associated with Christian ideas were Chaucer and Milton, as shown on Table 33. Their works cannot be 
interpreted apart from the Christian milieux of their respective eras. Among the sampling, seven curricula offered courses exclusively given to Chaucer's works, and nine to Milton. While these courses were offered by the three types of English curricula, they dominated the Type 1.0 Straight Literature type $(N=11)$ with six courses given to Chaucer and seven to Milton.

Statistically, that figure meant that a Type 1.0 curriculum had nearly a $64 \%$ chance of offering a Chaucer course and nearly a $55 \%$ chance of a Milton course. Among the Type 1.5 Primarily Literature curricula $(N=4)$, there was only a $25 \%$ probability for each course appearing. Among the 2.0 More Flexible curricula $(N=5)$, there was a $20 \%$ likelihood that a course on Chaucer would appear, and $40 \%$ chance that one would appear for Milton. Table 33 shows which curricula offered those courses given exclusively to Chaucer and to Milton. Johnson was the only other pre-20 $0^{\text {th }}$-century writer strongly associated with Christianity who had a course given solely to his writings.

\section{Major Authors Associated With Christianity Throughout the $20^{\text {th }}$ Century}

The fourth type of explicit evidence of Christian thought and influence appeared through the courses given to and featuring major authors associated with Christianity during the $20^{\text {th }}$ century. Although I had expected C. S. Lewis to figure within this category, I underestimated the extent of his role. Seven curricula among the purposeful sampling of 20 offered courses focusing on and/or featuring the work of C. S. Lewis. Three curricula, reported on Table 33, had courses bearing his name and all appearing at the senior level: Dallas Baptist University offered "ENGL 4315 C. S. Lewis," and Seattle Pacific University listed "ENG 4661 The Best of C. S. Lewis" and "ENG 4291 Directed 
Readings in the C. S. Lewis Circle." Four other curricula had courses which included Lewis and other Christian-oriented writers-including "The Inklings" colleagues Charles Williams and J. R. R. Tolkien. Such courses included (a) "ENG 434 Modern Mythology" at Wheaton College, (b) "ENGL 390 Special Topics in Literature" at Houghton College, and (c) "ENGL 2200 Literary Passages: The Oxford Christians" at King College.

Other curricula also may have included C. S. Lewis, but their course descriptions lacked specificity. For instance, Colorado Christian University offered "ENG 380 Christian Writers" which concerned "modern Christian writers" but identified none by name (Colorado Christian University Catalog, 2001-2002, 2001, p. 125). For a second instance, Bethel College (MN) required "ENL 499 Senior Seminar: The Writer as Believer," annually varying its featured authors. Since Bethel College offered four other courses taught in Great Britain, and since Lewis represented the foremost British apologist of $20^{\text {th }}$-century Christianity, his writings may well have appeared in the senior seminar.

Among $20^{\text {th }}$-century writers associated with Christian thought and influence, only C.S. Lewis had courses given solely to his texts. No other author received such attention among the purposeful sampling of curricula. Writers associated with Lewis also figured in a number of courses and may have been referenced in those given to his works. These included the following writers (whose number of citations appears in parentheses): J. R. R. Tolkien (2), Charles Williams (2), Dorothy Leigh Sayers (1), and George MacDonald (1). Notably, these represented solely British writers. Only two American writers were mentioned a number of times: T. S. Eliot, whose life-long residence in England meant he 
could represent both literatures, was listed 10 times among the sampling within the context of modern poetry and literary criticism. Flannery O'Connor's name was mentioned four times within the context of modern fiction. Other leading writers associated with Christian thought included W.H. Auden (1), Anne Lamott (1), Madeleine L'Engle (1), and Larry Woiwode (1). Lack of specificity among course descriptions may have accounted for other names, such as Walker Percy, not appearing.

In sum, the purposeful sampling of 20 CCCU curricula revealed four kinds of explicit evidence to Christian thought and influence appearing indiscriminately among the three types of curricula represented. The first category was the most obvious, of course-biblical content courses, numbering five and appearing exclusively at the junior level. The second category, courses representing the integration of Christian thought with English studies, appeared to require greater synthesis. These courses numbered seven, of which five represented senior seminar courses. The third category of explicit evidence constituted courses given to major authors associated with Christianity through the $19^{\text {th }}$ century; these proved the dominant type. Nineteen courses devoted to major authorsmostly Chaucer and Milton-appeared among 9 of the 20 curricula in the purposeful sampling. These courses appeared mainly among Type 1.0 Straight Literature curricula, but they also figured in the other curricular types (as shown on Table 33). The fourth category of evidence, $20^{\text {th }}$-century major authors associated with Christianity, featured C. S. Lewis as the foremost writer. Lewis was named in seven of the nine courses listed and was featured as the subject of three.

Cumulative evidence to Christian thought completed research question 2.0, though I had considered also addressing implicit evidence. Implied witness to the faith, 
however, yielded little data among these curricular documents-although such evidence undoubtedly occurred at the syllabi and class materials levels. Cumulative evidence can be approximated, however, and described on the basis of the purposeful sampling of 20 CCCU curricula.

To describe the cumulative evidence of Christian thought within the sampling, I first reviewed my journal, then rescanned the curricula themselves, and finally chose six to discuss. For each of the three types of English majors, I chose a pair of curricula to show one making few references to Christian thought and the other making many. This approach suggested what I had otherwise found difficult to sketch — the varying degrees of Christian thought infused into the purposeful sampling. Type 1.0 Straight Literature curricula were represented by Gordon College, for few references, and by Lee University, for many mentions (shown on Tables 34 and 35). Type 1.5 Primarily Literature plans were represented by Malone College and Dordt College (shown on Tables 36 and 37); and Type 2.0 More Flexible plans were represented by Simpson College and Seattle Pacific University (on Tables 38 and 39).

For each pair, I determined all references to Christianity wherever they appeared in the curricula whether in introductory statements, including goals, objectives, or other declarations; in survey course descriptions, including author, group, and/or movement names; in other course types and their descriptions, including author, group, and/or movement names; and, finally, in course titles and content descriptions (other than author, group, or movement). Then I analyzed differences and similarities between each typed pairs. 
The Type 1.0 Straight Literature curricula discussed for evidence of Christian thought and influence included Gordon College and Lee University, whose enrollment sizes certainly affected the number of courses offered. With a reported enrollment of 1,528 (shown on Table 34), Gordon offered 24 courses with 15 at the upper levels (shown on Table 21).

Lee University, with an enrollment nearing 3,000, offered 40 courses. These figures tempered my observations as a larger enrollment usually corresponded to a more extensive curriculum. Differences in size, however, did not account for the difference in the weight given to Christian concerns, as a comparison shows between Lee University (Table 35) and Gordon College (Table 34). Gordon College provided no introductory statement to its curriculum; thus, no mission statement, nor goals, nor objectives, nor any other commentary grounded Gordon's English curriculum in Christian thought.

In contrast, Lee University immediately established the Christian faith as its basic orientation. The Lee University Catalog, 2001-2002, declared in its introduction to the Department of English and Modern Foreign Languages:

The faculty believes strongly in a Christian world view and insists that such a view has practical implications for both content and pedagogy. All facts, concepts and understandings relevant to each field are presented from the perspective of the Christian view of a divinely created and ordered world under the lordship of Jesus Christ. (p. 160)

Less stridently but as certainly, the introduction to the Lee University English curriculum declared, "The capstone course, English in Christian Perspective 495, assists students in integrating their Christian faith with scholarship in the discipline" (p. 160). 
Table 34

References to Christian Thought in Type 1.0 Gordon College English Major Curriculum

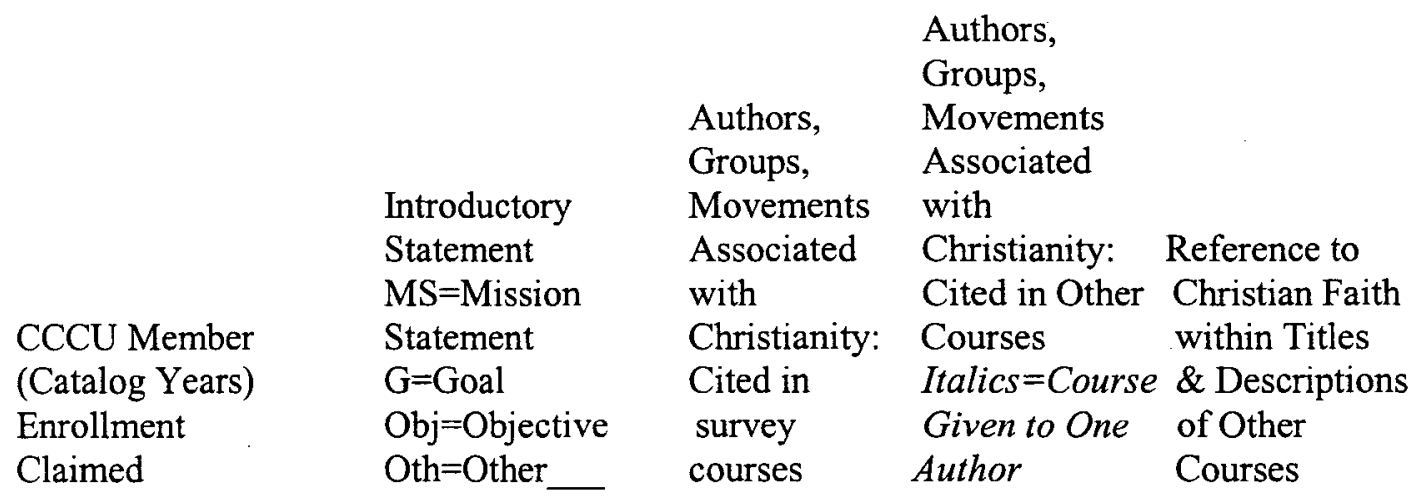

Milton

Swift

Yeats

Chaucer

(2001-2002)

$E=1528$ none

none
EN330 Milton and the Seventeenth Century, Johnson

"Culminates in reading Milton's Paradise Lost, set in context of severe religious, political and social crises" (p. 101).

EN348 Contemporary American Literature, "literature concerned with Jewish, Christian, feminist and minority issues" (p. 101).

EN360 Biblical Narrative "Analyzes major themes ... from Old Testament and gospel narratives" (p. 102).

From Gordon College academic catalog 2001-2002. (2001). Wenham, MA: The United College of Gordon and Barrington. Adapted with permission. 


\begin{tabular}{|c|c|c|c|c|}
\hline $\begin{array}{l}\text { CCCU Member } \\
\text { (Catalog Years) } \\
\text { Enrollment } \\
\text { Claimed }\end{array}$ & $\begin{array}{l}\text { Introductory } \\
\text { Statement } \\
\text { MS=Mission } \\
\text { Statement } \\
\text { G=Goal } \\
\text { Obj=Objective } \\
\text { Oth=Other }\end{array}$ & $\begin{array}{l}\text { Authors, } \\
\text { Groups, } \\
\text { Movements } \\
\text { Associated } \\
\text { with } \\
\text { Christianity: } \\
\text { Cited in } \\
\text { survey } \\
\text { courses }\end{array}$ & $\begin{array}{l}\text { Authors, } \\
\text { Groups, } \\
\text { Movements } \\
\text { Associated } \\
\text { with } \\
\text { Christianity: } \\
\text { Cited in Other } \\
\text { Courses } \\
\text { Italics = Course } \\
\text { Given to One } \\
\text { Author }\end{array}$ & $\begin{array}{l}\text { Reference to Christian Faith } \\
\text { within Titles \& Descriptions } \\
\text { of Other Courses }\end{array}$ \\
\hline $\begin{array}{l}\text { Lee University } \\
(2001-2002) \\
E=c .3,000\end{array}$ & $\begin{array}{l}\text { Oth: } \\
\text { "The faculty } \\
\text { believes strongly } \\
\text { in a Christian } \\
\text { world view [and } \\
\text { teaches] from } \\
\text { the perspective } \\
\text { of the Christian } \\
\text { view of a divinely } \\
\text { created and } \\
\text { ordered world } \\
\text { under the lordship } \\
\text { of Jesus Christ" } \\
\text { (p. 160). } \\
\text { "The capstone cours } \\
\text { [ENG } 495 \text { ] assists } \\
\text { students in integrat- } \\
\text { ing their Christian } \\
\text { faith with scholar- } \\
\text { ship in the disciplin } \\
\text { (p. 160). }\end{array}$ & $\begin{array}{l}\text { se } \\
\text { se" } \\
\text { e" }\end{array}$ & $\begin{array}{l}\text { Chaucer } \\
\text { Johnson } \\
\text { Milton } \\
\text { Swift }\end{array}$ & $\begin{array}{l}\text { ENG325 Literature of the Bible } \\
\text { "An introduction to the literary } \\
\text { forms of the Bible" (p. 169) } \\
\text { ENG495 English in Christian } \\
\text { Perspective, "English majors } \\
\text { are assisted in the integration of } \\
\text { the various facets of the major } \\
\text { in relation to . . disciplinary } \\
\text { concepts and overarching } \\
\text { philosophical, theological and } \\
\text { ethical concepts, guided by } \\
\text { Christian perspective of truth" } \\
\text { (pp. 171-172). }\end{array}$ \\
\hline
\end{tabular}

From Lee University undergraduate catalog 2001-2002. Lee University, 2001.

Cleveland, TN: Lee University. Adapted by permission. 
In contrast, Lee University immediately established the Christian faith as its basic orientation. The Lee University Catalog, 2001-2002, declared in its introduction to the Department of English and Modern Foreign Languages:

The faculty believes strongly in a Christian world view and insists that such a view has practical implications for both content and pedagogy. All facts, concepts and understandings relevant to each field are presented from the perspective of the Christian view of a divinely created and ordered world under the lordship of Jesus Christ. (p. 160)

Less stridently but as certainly, the introduction to the Lee University English curriculum declared, "The capstone course, English in Christian Perspective 495, assists students in integrating their Christian faith with scholarship in the discipline" (p. 160).

Both Gordon College and Lee University gave cursory descriptions of their respective literature survey courses; so both listed few major authors and/or movements associated with Christianity. But among their non-survey courses, both schools-despite their size inequality—listed similar names: Chaucer, Johnson, Milton, and Swift. Gordon College also named Yeats.

In naming major authors, then, the schools' enrollment sizes did not appear to make much difference. Nor did difference in size affect the number of biblical content offerings. Each school offered one biblical content course at the junior level: Gordon College listed EN 360 Biblical Narrative, and Lee University listed ENG 324 Literature of the Bible. Both devoted similar attention to the integration of faith and literature: Gordon addressed issues concerning faith and literature in its EN 330 Milton course, as well as its EN 348 Contemporary American Literature course, whereas Lee University stressed the integration of faith and English studies through its capstone course, EN 495 English in Christian Perspective. Therefore, despite their differences in enrollment size, 
both Gordon College and Lee University gave similar attention in course descriptions to Christian thought, but only the latter articulated the grounding of its English curriculum in the Christian faith.

The Type 1.5 Primarily Literature curricula which I chose to examine for the attention or weight they gave to Christian thought were Malone and Dordt Colleges, whose respective enrollments approximated 2,100 and 1,400 (shown on Tables 36 and 37). For this pair, the larger represented the school with fewer references to Christian thought within its English curriculum. Even though the Malone College English curriculum provided an introductory statement with goals, whereas the Dordt did not, the larger did not show the emphasis that the smaller gave to Christian thought, especially to its integration with English studies.

The Malone English curriculum began with a full-column introduction which stressed "[preparing] students to think analytically and to communicate articulately." Unfortunately, it then offered a syntactically poor statement: "Surrounded by a Christian atmosphere, a major in English, Integrated Language Arts, Spanish, or Spanish education equips students to lead purposeful and productive lives as educated members of the communities in which they live, worship, and work" (Malone College Catalog 20012002, 2001, p. 87). The introductory dependent phrase "Surrounded by a Christian atmosphere" needed to modify a noun such as "a student" rather than an abstract noun (phrase) such as "a major [program] in English." As I observed in my journal, "This phrase serves as a global, but indefinite descriptor, suggesting but not evidencing influence of Christian thought" (Appendix E). 
Table 36

References to Christian Thought in Type 1.5 Malone College English Major Curriculum

\begin{tabular}{|c|c|c|c|c|}
\hline $\begin{array}{l}\text { CCCU Member } \\
\text { (Catalog Years) } \\
\text { Enrollment } \\
\text { Claimed }\end{array}$ & $\begin{array}{l}\text { Introductory } \\
\text { Statement } \\
\text { MS=Mission } \\
\text { Statement } \\
\text { G=Goal } \\
\text { Obj=Objective } \\
\text { Oth=Other }\end{array}$ & $\begin{array}{l}\text { Authors, } \\
\text { Groups, } \\
\text { Movements } \\
\text { Associated } \\
\text { with } \\
\text { Christianity: } \\
\text { Cited in } \\
\text { survey } \\
\text { courses }\end{array}$ & $\begin{array}{l}\text { Authors, } \\
\text { Groups, } \\
\text { Movements } \\
\text { Associated } \\
\text { with } \\
\text { Christianity: } \\
\text { Cited in Othe } \\
\text { Courses } \\
\text { Italics=Course } \\
\text { Given to One } \\
\text { Author }\end{array}$ & $\begin{array}{l}\text { Reference to } \\
\text { Christian Faith } \\
\text { within Titles } \\
\text { \& Descriptions } \\
\text { of Other } \\
\text { Courses }\end{array}$ \\
\hline $\begin{array}{l}\text { Malone College } \\
(2001-2002) \\
E=2,100\end{array}$ & $\begin{array}{l}\text { Oth: "Surrounded } \\
\text { by a Christian } \\
\text { atmosphere" } \\
\text { (p. } 87 \text { ) }\end{array}$ & & & $\begin{array}{l}\text { ENG } 322 \text { World } \\
\text { Literature "A close } \\
\text { reading of diverse } \\
\text { historical, cultural, and } \\
\text { religious contexts" } \\
\text { (p. 89). }\end{array}$ \\
\hline
\end{tabular}

From Malone College catalog 2001-2002. Malone College, 2001. Canton, OH: Malone College. Adapted with permission.

The only other apparent reference to Christianity within the Malone English curriculum proved similarly global and vague in describing ENG 322 World Literature: "A close reading of texts from diverse historical, cultural, and religious contexts" (Malone College Catalog 2001-2002, 2001, p. 89). No other reference, not any of the four types of Christian evidences, pointed to Christian influence. The Malone English curriculum did not specify the names of authors studied, the titles of texts assigned, the movements, or the approaches addressed. Thus, I concluded in my journal for Malone that "I find no hard evidence of Christian thought in this curriculum which [claimed] in its introduction to be '[surrounded] by a Christian atmosphere"' (Appendix E). 
In contrast, the Dordt College English curriculum gave evidence of Christian thought and influence throughout its course descriptions. Although it lacked both an introduction and a course given to biblical literature, the Dordt curriculum included (a) 17 authors whose works cannot be discussed apart from Christianity, (b) three statements on the integration of Christian faith and English studies, and (c) one notation of "Scriptural tradition" being stressed in course content (as shown on Table 37).

The Dordt list of authors evoking Christian ideas and issues extended from the late $16^{\text {th }}$ to mid- $20^{\text {th }}$ centuries: That is, the list went from Erasmus to Yeats (as shown on Table 37). The Dordt curriculum included many of the more influential literary names such as Chaucer, Hawthorne, and T. S. Eliot, but yet some lesser names such as Bunyan, Herbert, Goldsmith, and Auden. Indeed, this type of evidence to Christian thought and expression proved stronger within the curriculum than direct references.

Clear references to Christian thought, however, also appeared within the Dordt curriculum, especially within literary course descriptions. "American Literature 202," for instance, declared that "Students will be expected to respond ... f from their own Christian points of view" (Dordt College Catalog, 2001-2002, 2001, p. 134). "Themes in Literature 222" involved "the search for religious certainty" (p. 135); "Earlier British Literature 314" claimed that "Special attention will be paid to the Scriptural tradition which this literature evokes" (Dordt College Catalog, 2001-2002, 2001, p. 136). "History and Theory of Literary Criticism 333" identified one aim as "formulating clearer Christian theories of literature" (p. 137). "Fiction Writing 304" concerned "the ways one's faith affects the writing of fiction" (p. 136). Such statements openly grounded the Dordt College English curriculum in Christian thought. 
Table 37

References to Christian Thought in Type 1.5 Dordt College English Major Curriculum

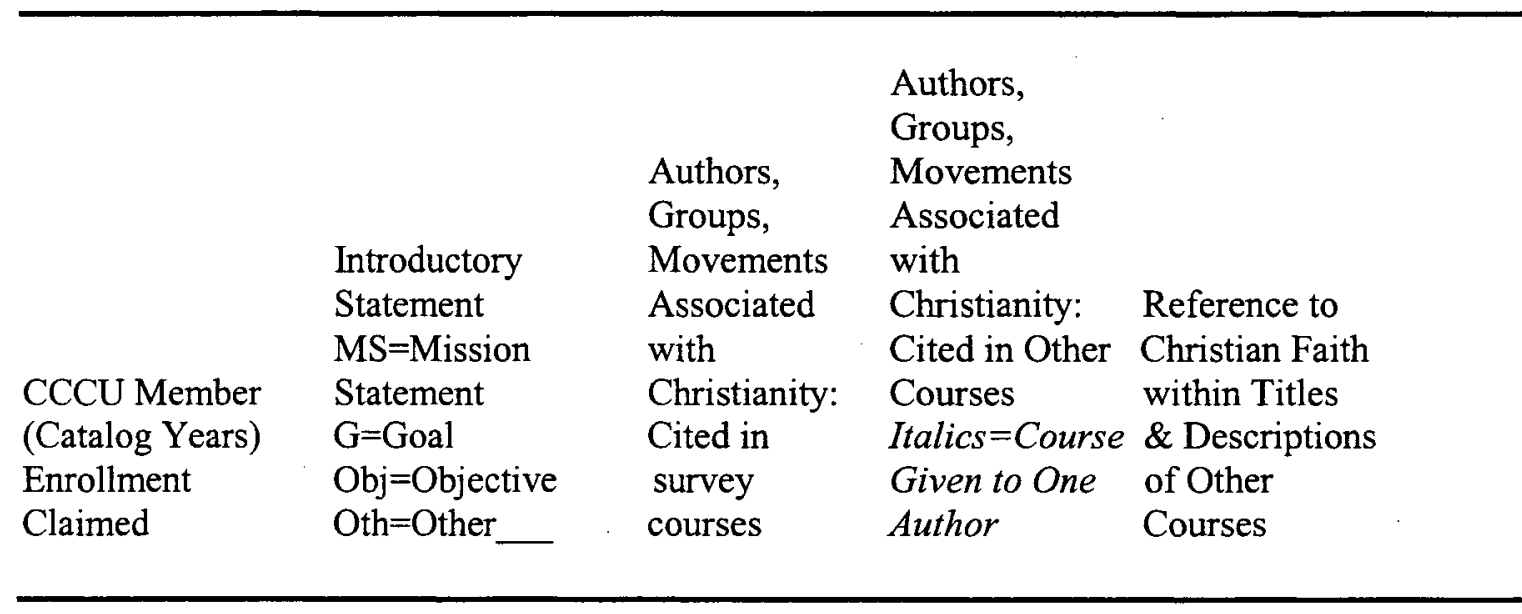

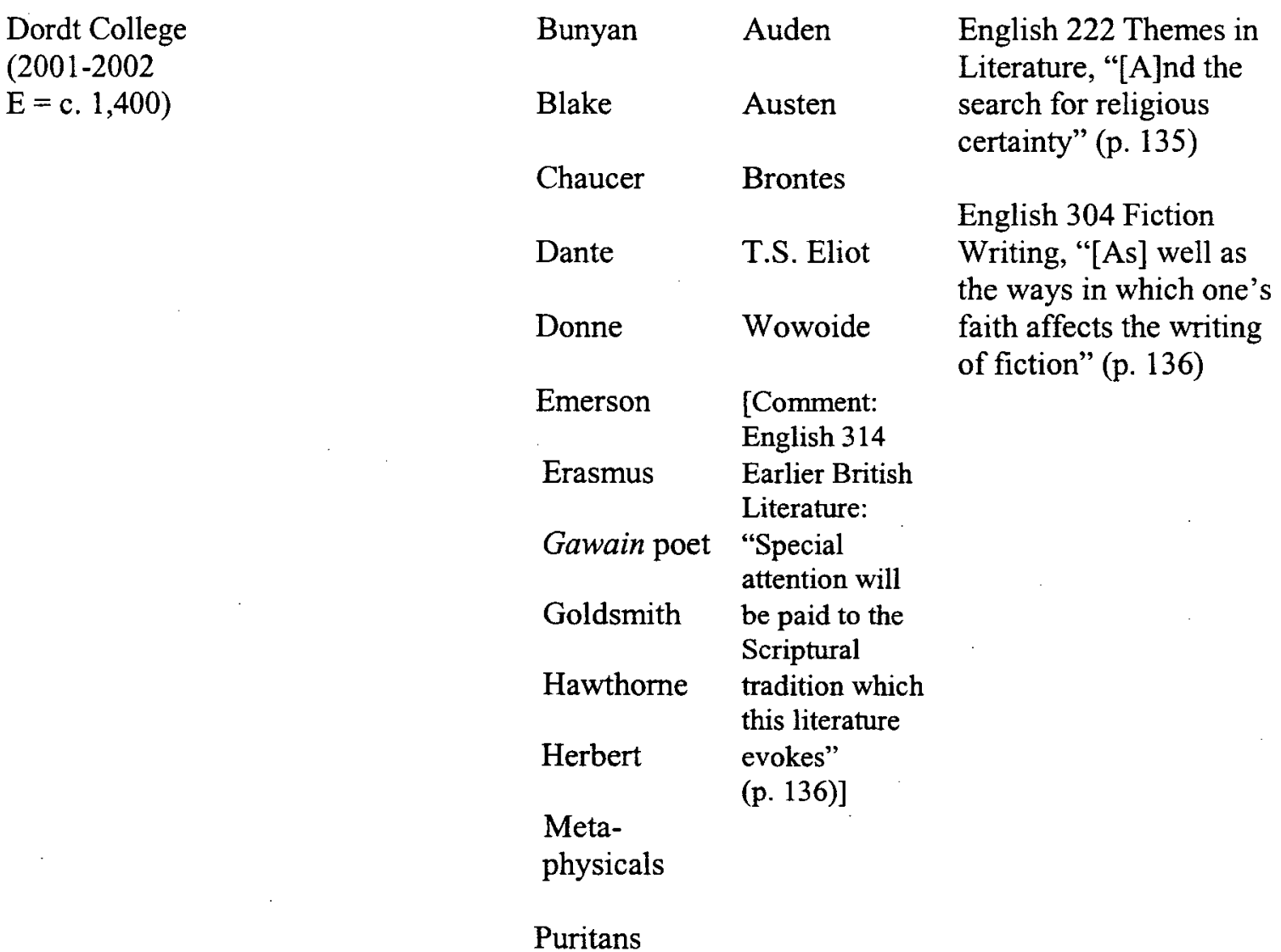




\begin{tabular}{|c|c|c|c|}
\hline $\begin{array}{l}\text { CCCU Member } \\
\text { (Catalog Years) } \\
\text { Enrollment } \\
\text { Claimed }\end{array}$ & $\begin{array}{l}\text { Introductory } \\
\text { Statement } \\
\text { MS=Mission } \\
\text { Statement } \\
\text { G=Goal } \\
\text { Obj=Objective } \\
\text { Oth=Other }\end{array}$ & $\begin{array}{l}\text { Authors, } \\
\text { Groups, } \\
\text { Movements } \\
\text { Associated } \\
\text { with } \\
\text { Christianity: } \\
\text { Cited in } \\
\text { survey } \\
\text { courses }\end{array}$ & $\begin{array}{ll}\text { Authors, } & \\
\text { Groups, } & \\
\text { Movements } & \\
\text { Associated } & \\
\text { with } & \\
\text { Christianity: } & \text { Reference to } \\
\text { Cited in Other } & \text { Christian Faith } \\
\text { Courses } & \text { within Titles } \\
\text { Italics=Course } & \text { \& Descriptions } \\
\text { Given to One } & \text { of Other } \\
\text { Author } & \text { Courses }\end{array}$ \\
\hline & & $\begin{array}{l}\text { Yeats } \\
\text { [Comment: } \\
\text { American } \\
\text { Literature } 201 \\
\text { "Students will } \\
\text { be expected to } \\
\text { respond to the } \\
\text { literature from } \\
\text { their own } \\
\text { Christian } \\
\text { point of view" } \\
\text { (p. 134).] }\end{array}$ & $\begin{array}{l}\text { [Comment: } \\
\text { English } 333 \\
\text { History and } \\
\text { Theory of } \\
\text { Literary } \\
\text { Criticism: } \\
\text { "with the aim of } \\
\text { formulating } \\
\text { clearer Christian } \\
\text { theories of } \\
\text { literature" } \\
\text { (p. 137).] }\end{array}$ \\
\hline
\end{tabular}

$\overline{\text { From Dordt College 2001-2002 catalog. Dordt College, 2001. Sioux Center, IA: Dordt College. }}$ Adapted with permission.

The Type 2.0 More Flexible English Major curricula discussed for evidence of Christianity were Simpson College and Seattle Pacific University, a pair contrasting considerably in the attention afforded to Christian thought. The introduction Simpson College provided for its English curriculum established its career relevancy, its general organization, and its transitional status, but made no mention of Christian thought.

In contrast, Seattle Pacific University underscored its Christian orientation through such statements as (a) "Literature courses show how language enables us to 
explore and shape our views of God, humanity, and the earth,” (b) “An English major prepares students to enter professions such as the ministry, law, social work or medicine," and (c) "[It prepares them] to enter life with an appreciation for God's gifts of language and literature" (Seattle Pacific University Undergraduate Catalog 2001-2002, 2001, p. 128). The university also underscored its Christian orientation through its first objective: "[To understand] the relationship between literature and the Christian faith, and gain insight into the study of literature as a means of clarifying one's own values" (p. 128).

So, in contrast to its Simpson College counterpart, the Seattle Pacific University English curriculum firmly established its orientation to Christianity. The two also differed in the evidence their respective course descriptions afforded to Christian thought. Simpson College, with a reported enrollment of some 1,330 students, offered 27 English courses; 3 referred to Christianity. "American Literature 2210" listed "Puritanism" among its literary subjects; "Western Literature 3210," subtitled "Classical and Christian Traditions," referred to "religious contexts"; and "Drama Practicum 2280/3281" treated "dramatic works related directly or indirectly to the Christian faith" (Simpson College 2001-2002 Catalog, 2001 p. 85). As the Simpson curriculum identified no authors by name, the weight of its Christian evidence relied on such generalizations (as shown on Table 38).

Seattle Pacific University, with its much larger enrollment of 2,636 students and its greater number of English courses $(N=46)$, stressed Christian influence through the study of major authors whose texts make Christianity integral to their interpretation. Fourteen of these names appeared among survey courses, while 10 figured among higher level offerings. Major figures included Dante and Chaucer from the Middle Ages, Donne 
Table 38

References to Christian Thought in Type 2.0 Simpson College English Major Curriculum

\begin{tabular}{|c|c|c|c|c|}
\hline & & & $\begin{array}{l}\text { Authors, } \\
\text { Groups, }\end{array}$ & \\
\hline & & $\begin{array}{l}\text { Authors, } \\
\text { Groups. }\end{array}$ & $\begin{array}{l}\text { Movements } \\
\text { Associated }\end{array}$ & \\
\hline & Introductory & Movements & with & \\
\hline & Statement & Associated & Christianity: & Reference to \\
\hline & $\mathrm{MS}=\mathrm{Mission}$ & with & Cited in Other & Christian Faith \\
\hline CCCU Member & Statement & Christianity: & Courses & within Titles \\
\hline (Catalog Years) & $\mathrm{G}=\mathrm{Goal}$ & Cited in & Italics $=$ Course & \& Descriptions \\
\hline Enrollment & Obj=Objective & Survey & Given to One & of Other \\
\hline Claimed & Oth=Other & courses & Author & Courses \\
\hline
\end{tabular}

Simpson College

2001-2002

(c. 1,300$)$

Puritanism

\author{
ENGL2280 \& ENGL3210 Western \\ 2281 Drama Literature: Classical and \\ Practicum, \\ Christian, "setting \\ "production \\ and \\ works into historical, \\ cultural, political, and \\ performance \\ of works \\ directly or \\ indirectly \\ related to the \\ Christian faith \\ (p. 85)
}

From Simpson College \& Graduate School 2001-2002 catalog. Simpson College, 2001. Redding, CA: Simpson College. Adapted with permission.

and Milton from the Renaissance, Hawthorne and Dostoevsky from the $19^{\text {th }}$ century, and T. S. Eliot and C. S. Lewis from the $20^{\text {th }}$. Table 38 records lesser figures, too, including authors associated with Lewis. The Seattle Pacific University listings for both survey and advanced courses constituted its most numerous type of Christian evidence. 
Evidence to the integration of the Christian faith and English in the Seattle Pacific University curriculum appeared within 3 course descriptions. "Practical Criticism 2225" had "consideration of Christian approaches to criticism"; "Literature of the American West 2230" concerned the role of "place in shaping the literature and spirituality of writers in the West"; and the "Senior Capstone Seminar 4225" required students to "[reflect] upon the relationship between faith and the discipline [sic] of literary studies" (Seattle Pacific University Undergraduate Catalog, 2001-2002, 2001, p. 131).

The English major curriculum at Seattle Pacific University marshaled much more evidence of Christian thought than its counterpart, Type 2.0 curriculum at Simpson College. The former provided much more specific course descriptions than the latter, allowing it to underscore the study of texts reflected a spectrum of thought involving Christianity. From the late medieval poet Chaucer, writing at the time of Wycliffe on the eve of the Reformation, to the modernist, Christian poet T. S. Eliot, writing through a spiritual wasteland, over 20 major authors concerned with Christianity appeared in the Seattle Pacific University curriculum. None appeared within the Simpson curriculum.

The contrast between the two curricula (evident through Tables 38 and 39) concluded my attempt to suggest how the cumulative evidence to Christian thought differed even within the same types of English majors among the purposeful sampling. Simpson College generalized its three courses descriptions referring to Christian thought, referring merely to "Puritanism" in a survey course, to "works directly or indirectly related to the Christian faith" in a drama course, and to "Christian...religious contexts" in a Western literature course. In contrast, in its course descriptions, Seattle Pacific University specifically named 22 authors associated with Christianity 
Table 39

References to Christian Thought in Type 2.0 Seattle Pacific University English Major Curriculum

\begin{tabular}{|c|c|c|c|c|}
\hline & Introductory & $\begin{array}{l}\text { Authors, } \\
\text { Groups, } \\
\text { Movements }\end{array}$ & $\begin{array}{l}\text { Authors, } \\
\text { Groups, } \\
\text { Movements } \\
\text { Associated } \\
\text { with }\end{array}$ & \\
\hline & $\begin{array}{l}\text { Statement } \\
\text { MS=Mission }\end{array}$ & $\begin{array}{l}\text { Associated } \\
\text { with }\end{array}$ & $\begin{array}{l}\text { Christianity: } \\
\text { Cited in Other }\end{array}$ & $\begin{array}{l}\text { Reference to } \\
\text { Christian Faith }\end{array}$ \\
\hline CCCU Member & Statement & Christianity: & Courses & within Titles \\
\hline (Catalog Years) & $\mathrm{G}=\mathrm{Goal}$ & Cited in & Italics $=$ Course & \& Descriptions \\
\hline Enrollment & Obj=Objective & Survey & Given to One & of Other \\
\hline Claimed & Oth=Other & courses & Author & Courses \\
\hline
\end{tabular}

Seattle Pacific U. Oth: "show how (2001-2002)

(c. 2,636)

language enables us to explore and shape our views of God" (p. 128).

Oth: "prepares students to enter professions such as the ministry" (p. 128).

G: "to enter life with an appreciation for God's gifts of language and literature" (p. 128).

Obj. $(G)$ :

"Understand the relationship between literature and [Christianity]" (p. 128).

\section{Blake Brontes ENG2225 Practical \\ Criticism: Writing and \\ Chaucer Donne Research, "Includes consideration of \\ Dante Herbert Christian approaches to criticism" (p. 130).}

\section{Dickinson C.S. Lewis the American West, "emphasis [on] place in shaping the literature and spirituality of \\ Dostoevsky O'Connor \\ T.S. Eliot C. Rosetti writers in the West" (p. 130).}

Emerson Dorothy L.

Sayers

Gawain poet

J.R.R.

Hawthorne Tolkien

Herbert Charles

Williams
ENG4225 Senior Capstone Seminar, "reflects upon the relationship between faith and the discipline of literary studies" (p. 131). 


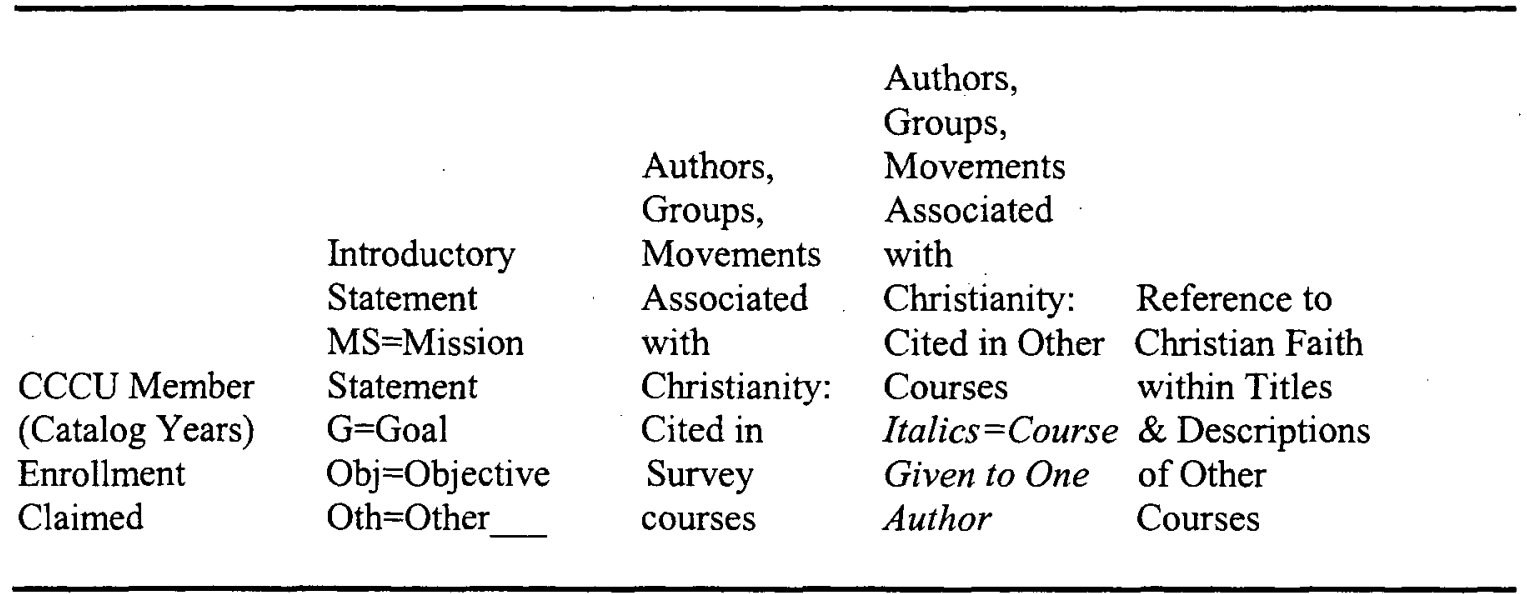

Seattle Pacific U. Oth: Image:

A Journal of the

Arts and Religion

(p. 128).

From Seattle Pacific University Undergraduate Catalog 2001-2002. Seattle Pacific University, 2001. Seattle, WA: Seattle Pacific University. Adapted with permission.

\section{Summary of the Nature and State of the English Curriculum}

The purposeful sampling of $20 \mathrm{CCCU}$ English major curricula, reflective of the population of 98 offering the major, showed 3 of Stewart's (1989) Modified Categories of English Major types: (a) Type 1.0 Straight Literature major dominated, comprising $55 \%$ of the sampling $(N=20)$, (b) Type 1.5 Primarily Literature major represented $20 \%$, and (c) Type 2.0 More Flexible major made up 25\%. All three types were literature based majors, but their percentages differed: Type 1.0 curricula had $75 \%$ or more of its 200 - to 400-level courses given to literature; Type 1.5 had $65 \%$ to $74 \%$; and, Type 2.0 had up to $64 \%$. The feature which differentiated Type 1.5 was possession of a writing program or of a number of writing courses beyond the stock offerings of advanced composition and 
creative writing. What differentiated Type 2.0 , besides flexibility in program completion, was its accretion of electives-especially writing electives-and its user-friendliness.

Among these types, 3 broad claims appeared concerning the preparatory role of the English major. The curricula claimed to prepare students for (a) graduate studies, (b) professions and careers, particularly in law, ministry, journalism, medicine, business, and media; and, (c) teaching, particularly at the secondary level. Although other claims did appear, including the integration of faith and knowledge, the profession-and-careerpreparatory claims outweighed them and represented recurring themes.

Many curricula did not articulate any goals, but those that were expressed tended to be intellectual in nature and oriented to literature. Five of seven goals specified among the sampling addressed the understanding of literature, mainly British/English and American literatures; one addressed the usage of the English language; another concerned the history of the English language. No major-specific goal specifically addressed composition, writing, or rhetoric. Goals for these appeared under service-related rather than major-related statements, but such goals proved few in number.

The sampled curricula revealed two structural organizations for the English major curricula: (a) the traditional tripod of literature, language, and grammar or linguistics; and, (b) the core-and-periphery model with traditional literature comprising most of the required core, but with other concerns including language, linguistics, writing, and minority literatures emanating in that order toward the outer edge. Though Types 1.0 and 1.5 curricula tended toward the tripodal structure, Type 2.0 appeared only in core-andperiphery structures, with their characteristic feature - the swollen periphery of writing electives. The sampling indicated that the further an English curriculum departed from 
Type 1.0, the more likely it would have a core-and-periphery structure.

One structural characteristic shared, however, among the three types was the vestigial, field-coverage organization of higher-level literature courses. This meant that junior and senior literature courses were designed and categorized according to British/ English and American historical periods and/or movements such as Victorian Literature or Romanticism. Type 2.0 majors, however, showed this characteristic the least.

The content of the sampled curricula showed that the three types shared a basis of literature, but had particular characteristics. Type 1.0 Straight Literature, representing $55 \%$ of the sample $(N=20)$, emphasized literary genres, British/English literature, and American literature. Genres allowed this type to conjoin those literatures for studies such as Romanticism, Modernism, and Post-modernism. Literature surveys appeared in 5 to 6 of the Type 1.0 curricula at the 200 and 300 levels $(N=11)$; the same number(s) (though differing by tracks) required a course in Shakespeare mainly at the 300 level. Among electives, British/English and American literature courses were prominent. The Type 1.0 major tended to offer world literature courses, but without the emphasis the other two literatures received. Offerings in linguistics, writing, rhetoric, journalism and media courses received minimal attention. Type 1.0 curricula slighted literary theory and criticism, but altogether omitted rhetoric and composition theory.

Type 1.5 Primarily Literature curricula, constituting $20 \%$ of the sampling $(N=$ 20), also showed British/English literature and American literature dominating their content; however, writing, rhetoric, and composition showed slighting much as the first type showed. Though linguistics played a minimum role as a requirement among Type 1.5 majors, as an elective it figured more importantly due to a probable connection to 
TESOL and TESOL-type programs. Adding to this type's more eclectic nature were its attention to overseas studies, as well as to practical and career experiences. Elective writing courses and minority literature courses also proved characteristic.

Type 2.0 More Flexible curricula, making up $25 \%$ of the sampling $(N=20)$ revealed these marked characteristics beyond the program flexibility basic to its nature: (a) Minority literatures such as Canadian and women's studies, appeared prominently in its periphery, and (b) writing electives, even more than minority literatures, swelled its periphery. Notably, creative writing courses contributed most to its expansion; so, however, did practical studies such as business or technical writing and professional writing. Nevertheless, the core of Type 2.0 curricula solidly remains literature.

These curricula revealed 6 patterns: (a) Type 1.0 tended to have structures based on the traditional tripod model of English, (b) Type 1.5 usually had core-and-periphery model structures, with the cores given to the traditional canon, (c) Type 2.0 had only core-and-periphery structures, (d) Type 2.0 showed a proliferation of electives, (e) all 3 types between 1997-1998 and 2002-2003 had expanded the role of writing, regardless of institutional size, and (f) all tended to offer a Shakespeare course, usually in their program requirements, at the junior or senior levels.

Curricular weaknesses apparent among all 3 types of English curricula included the (a) lack of articulated, published goals, (b) inadequate attention given to writing, composition, rhetoric, and literary criticism, (c) imbalance of course offerings, especially at the 300 level, (d) slighting of linguistics and linguistic-related courses, (e) inadequate attention given to non-Western and minority literatures, (f) inadequate attention given to practical-oriented courses and career-oriented studies, and (g) proliferation of electives. 
Curricular strengths among the 3 types represented content strengths primarily, but also an opportunity strength. Content strengths included (a) their mutual literary base, (b) dominance of British/English and American literatures, (c) offering of literary history/ theory/criticism among $70 \%$ of the purposeful sampling $(N=20)$, (d) offering seminar/ capstone courses among $50 \%$, and requiring them among $40 \%$ of the curricula sampled. The opportunity strength was the offering of practica and internship among $60 \%$ of the purposeful sampling.

Finally, Christian thought appeared among the purposeful sampling of CCCU English major curricula $(N=20)$ within 4 categories of courses: (a) biblical content, emphasizing study of the Bible for literary qualities, (b) integrated biblical and English, promoting the integration of faith and literature or faith and writing, (c) major authors associated with Christian thought from the $1^{\text {st }}$ through the $19^{\text {th }}$ Centuries, a category dominated by Chaucer and Milton; and (d) major authors associated with Christian thought during the $20^{\text {th }}$ Century, a category dominated by C. S. Lewis. In nearly every instance, these courses represented electives at the junior or senior level. The third category (c) represented the greatest number of courses-19 offered by the sampled curricula; the fourth category (d) offered 7 courses, with 3 bearing only the name of C. S. Lewis in their titles.

This summary closes the findings made through this exploratory study of the undergraduate English major curricula issued by the 2000-2001 Council for Christian Colleges and Universities. The next and final chapter presents a summary of this research study, its findings and conclusions, as well as its apparent significance and heuristic recommendations. 


\section{CHAPTER V}

\section{SUMMARY, CONCLUSIONS, AND RECOMMENDATIONS}

The purpose of this study was to explore and describe the undergraduate English major curricula issued by members of the 2000-2001 Council of Christian Colleges and Universities (CCCU) to determine the nature and state of the individual curricula and the aggregate curriculum, and especially to discern evidence of Christian thought. Chapter 3 articulated the two frameworks adopted for this study: Stewart's (1989) categories of English majors, modified for greater exactness, and Eisner's $(1985,1991)$ education

criticism. Chapter 4 presented the findings of this current study, whereas chapter 5 offers a review of its English and curriculum contexts, frameworks, methodology and findings. Chapter 5 summarizes the study, posits conclusions, and proffers recommendations.

\section{Context: English and Its Undergraduate Curriculum}

When Peter Elbow (1990) issued his reflective journal of the 1987 English Coalition, he provocatively entitled it What Is English?, as the traditional response-the discipline of literature, grammar (or language), and composition - no longer sufficed, but the emergent paradigm of "English studies" remained amorphous. Amidst this change, another Modern Language Association (MLA) researcher asked, "What Is an English Major, and What Should It Be?" Donald C. Stewart's (1989) qualitative study of 194 curricula resulted in the initial classification of English major types. Since Stewart's 
study included only one evangelical Christian college curriculum, his findings did not address a related question: What is an English major in the typically small, evangelical college or university? That question prompted this current, independent study of the 98 English major curricula issued at the century's change by the 101 members of the CCCU.

Due to a lack of research about undergraduate English curricula among Christian schools, this present study relied on the literature concerning the condition of the English major among secular, public, and private schools. Metaphorically, three overlapping waves of research crested and peaked during the final four decades of the $20^{\text {th }}$ century: (a) the survey and description wave from 1967 through the mid-1980s; (b) the qualitative analysis wave during the late 1989s; and (c) the case study wave from the early 1990 s onward.

Initiating the survey and description wave in 1967-68 with the first-ever national survey of English programs, Thomas Wilcox (1970) effected a comprehensive study cosponsored by the MLA, the National Council of Teachers of English (NCTE), and the then federal Office of Education (p. ix). Wilcox established the baseline for subsequent surveys, showing the prevailing structure of the undergraduate major as a tripod of studies-literature, grammar (or language), and composition. Literature appeared emphasized, or, as English scholars say, "privileged." Though Wilcox did not use the term "tripod," from his study onwards the term "tripod model" appeared regularly in discussion of the major.

The Wilcox survey prompted Peck's (1969) survey of undergraduate English programs among 45 schools affiliated with the then United Presbyterian Church (pp. 1 \& 5-6). Peck's dissertation represented the only study of undergraduate English among 
Christian liberal arts institutions prior to this present study. Like Wilcox $(1970,1973)$, Peck emphasized administrative policy matters, but he also reported the dominance of the tripod model with its emphasis on literature.

After sponsoring an uneven, descriptive profiling of selected curricula during the mid-1970s (Cowan, 1975), the MLA returned to surveying, but through its Association for Departments of English (ADE). Its "Report on the 1983-84 Survey of the English Sample" (Huber \& Young, 1986), marking the peaking of the first research wave, concluded that the "English major [had] remained stable - that is, dominated by British and American literature" (p. 46). During 1984-85, the wave began to ebb when the ADE made a related survey of English requirements in both general education and the English major; this also indicated that British and American literatures received emphasis and that survey courses proved "the most prescribed fares" for the major (Huber \& Laurence, 1989, p. 39).

The true ebb of the survey and description wave was Huber's inconsistent report of "Undergraduate English Programs: Findings from an MLA Survey of the 1991-92 Academic Year" (a report criticized by various scholars, especially by Balch \& Brasor, 2001). Faulty as it seemed, this survey did attempt to be more inclusive in its samplings, in part by giving private colleges greater representation. Like its predecessors, however, this survey concentrated on large institutions (Huber, 1996, p. 35) - a bias excluding many Christian liberal arts institutions (p. 35). Notably, Huber's published report omitted summary findings and conclusions; still, its evidence pointed to the continued hegemony of literature, especially American and British literatures. It also pointed to a greater 
reliance on genre courses for requirements (Huber, 1996, p. 60), and greater inclusion of world literature and literary theory and/or literary criticism (p. 63).

The second research wave, characterized by qualitative studies, occurred during the mid- to late-1980s, swelling with the 1985 MLA/ADE ad hoc committee study of published curriculum when its chair tentatively reported that the "basic configuration of the English major [appeared] to have changed only slightly since ... the Wilcox study" (Harris, 1986, p. 26). Other members faulted the chair's agenda: Waller (1986) and Lawrence (1988) argued for the committee's prescribing significant reform of the English major rather than describing its status. Waller promulgated his own Carnegie-Mellon major as a model grounded in rhetoric and focused on "[students'] cognitive processes" within discourse communities (1986, pp. 34 \& 37). Thus, reporting the Carnegie-Mellon reformed major, Waller anticipated the third research wave of case studies.

But the second wave swelled with Stewart's (1989) qualitative study of 194 undergraduate curricula published by selected public and private institutions. Notably, Stewart made the initial categorization of English majors, reporting three common types (of four found), all dominated by literature. As Stewart included only one evangelical institution in his population studied, his report did not address the English major among Christian liberal arts schools; his work, however, provided the impetus and first framework for this present study.

The second, qualitative research wave peaked with Elbow's (1990) journal of the 1987 English Coalition, an MLA-NCTE domination conference exploring the nature of English at all academic levels. Participants' questions distilled into his journal titleWhat Is English? Answers varied, but one actuality appeared: English had developed into 
a multidimensional field, larger and more varied than its former discipline. Although the new boundaries of English remained indistinct, the tripod model no longer sufficed for its undergraduate major.

During such change in the late 1980 s, theories roiled about the new nature of the English undergraduate major. Graff (1992) capitalized on the contemporary debates, and posited conflicts as its defining content although he recognized only literary conflicts and ignored writing and rhetoric. Applebee (1996) invoked dialogic studies to reform the curriculum metaphorically as conversation. Berlin (1996) argued, as he had for the two decades preceding the posthumous call, to reform the major as rhetoric. Scholes (1998) lamented the demise of literature's hegemony, but proposed a reformed curriculum on textual studies (i.e., the production, consumption, and critical analysis of texts).

As these leading theories swirled, the qualitative studies wave was overlapped and engulfed by the third wave- that of case studies (an old relative of qualitative research). In 1991, the MLA with federal funding initiated a curricular change program entitled "Fund for the Improvement of Secondary Education"-FIPSE (Branca, 1994, p. 7; Heller, 1992, p. 18; Spacks, 1993, pp. 3-4). Through FIPSE, the MLA addressed two common constraints to curricular review: the lack of departmental funds and the plentitude of faculty reluctance (Spacks, 1993, pp. 3-4). Branca's report of the Merrimack College English revision reflected stresses typical to the process: "controlling concepts and structures" compounded with faculty disagreement impeded the reform (1994, pp. 6 \& 10).

By late 1993, MLA president Spacks sounded pessimistic; the announced intention to reduce dependence on the historical coverage of literature and to intensify 
writing and critical methodologies had faltered (Spacks, 1993, pp. 3-4). FIPSE did not spur sweeping paradigmatic reform, though it did fund curricular reviews and revisions of 30 English major programs. These included a diversity of schools, from Willamette University (Long, 1994) to the State University of New York Oswego (Murphy \& O'Shea, 1997). FIPSE also created a research climate conducive to case studies. NonFIPSE case studies of revised curricula occurred at Ursinus College (Schroeder, 1993), Roger Williams College (Tackach, 1994), and West Virginia University (Francus, 2001).

The third wave of case studies has characterized the period of this current studythe turn of the $21^{\text {st }}$ century. The following institutions reported revised English curricula: University of Alabama (Weber, 2001); University of Louisville (Journet, 2001); Dickenson College (Moffat, 2003); and Montclair State University (Schwartz, 2003). Collectively, these reports stressed the roles of critical methodologies and critical thinking skills essential to English; they also argued for greater emphasis on interpretation and writing. Literature, however, remained an integral part of each revised curriculum. As case studies did not lend themselves to generalizing, this third wave of research on the English major has not generated a new theory or launched a reform movement.

\section{Context: Contemporary Curriculum Thought and Eisner}

As English experienced redefinition during the last decades of the $20^{\text {th }}$ century, the field of curriculum saw critical debate over its definition and focus-especially that part pertaining to curriculum (Jackson, 1992, p. 21). "Reconceptualist" scholars around 1970 began to reconceive the area of curriculum study as "curriculum theory" rather than "curriculum development"; that is, "a field concerned with understanding curriculum, 
informed by theory in the arts and humanities, and by social theory" (Pinar et al., 2004, p. 65). Reconceptualists, according to Jackson (1992), have been thought of as "curriculum theorists" rather than "curriculum specialists," as theorists concerned themselves primarily with social and political contexts whereas specialists dealt with designing and applying curriculum (pp. 21, 55-57).

In the context of undergraduate English, the difference between reconceptualizing and developing curriculum may be seen by contrasting two case studies for processes and emphases in curricular revision: Branca's (1994) report on the reconceptualized English major at Merrimack College versus Klein's (1983) report on the revised major at Bowling Green State University. Both reports appeared in the ADE Bulletin, and both stressed the need for curricular change.

Merrimack faculty began reconceptualizing their curriculum by "[identifying] theoretical issues underlying the definition and organization of undergraduate arts and science majors" (Branca, 1994, p. 8). This act "provided a context ... for discussion"; following discussion, faculty "[prepared] written definitions of the [English] major" for further discussion; this led them to identify what the major should do (p. 8) Then, as a committee, they established a theoretical, flexible framework for the major and placed pertinent courses within it (p. 8).

Bowling Green State English faculty, however, began revising their curriculum by "[anticipating] department needs and practices” for the next decade, emphasizing that "English [constituted] more than a body of information about texts"; it represented "a study and practice of certain powers of language and mind" (Klein, 1983, p. 28). After committee members identified those "powers ... and how they [were] to be honed," the 
members "defined specific contents of various courses and the skills to be stressed in each" (Klein, 1983, p. 28). The Bowling Green committee, following the influence of Wayne Booth, then "developed a rational plan [sequencing] skills, experiences, and literary contents," giving less emphasis to "literary heritage" and more to "a . . variety of mental faculties" (p. 31).

This comparison and contrast indicated the essential difference between the reconceptualized Merrimack College curriculum and the revised Bowling Green State University curriculum: Theory drove the Merrimack reconceptualized major, whereas development fueled the Bowling Green revised major. Merrimack faculty emphasized "intellectual interest in [a broad understanding of] curriculum; the Bowing Green faculty stressed particular process details (such as sequencing).

Though Reconceptualists (with a capital R) regarded Tyler's (1949) rationale for curriculum out-of-date (Eisner, 1992, p. 317; Lincoln, 1992, p. 84) for lacking political and historical contexts (Jackson, 1992, p. 35; Lincoln, 1992, pp. 82 \& 84), they also resisted "the extreme rationality in the scientific management movement" (Eisner, 1992, p. 317; Lincoln, 1992, p. 85). Reconceptualists, however, have not had a full-blown theory of curriculum or any "agenda for effecting change" (Lincoln, 1992, p. 83). Eisner (1992) has regarded Reconceptualism as an orientation to curriculum rather than a theory of curriculum (p. 317).

"Orientation" appeared a fitting evaluation of Reconceptualism to me when I sketched Lincoln's metaphorical “curricular compass" (1992, p. 85) modified by Pinar's conception of the contemporary curricular field. Two horizontal hemispheres divided the field: the eastern representing the humanistic domain and the western the scientific 
domain. At "due north," Pinar (of Pinar et al., 2004) commanded the curricular theory pole; opposed, Tyler represented curriculum development. Their polar opposition defined the extreme orientations to the contemporary curriculum field. Within those orientations and under their respective influences stand aesthetic criticism at "due east" in the humanist sphere, and positivism at "due west" in the behavioralist sphere, Eisner's education criticism which recognizes multiple ways of knowing oversees the eastern sphere; positivists, who regard scientific objectivity as the sole basis for knowledge, rules the western.

Eisner's position represented the curricular orientation for this present study, for his education criticism advocates constructed meaning as the core of curriculum (1992, pp. 7 \& 13-22; Lincoln, 1992, p. 90). "We learn to see, or at least we learn to see those aspects of the world that are subtle and complex," explained Eisner in The Enlightened Eye, and "[we] can only appraise and interpret what we have been able to experience" (1992, p. 17). Basic to seeing and interpreting texts, visuals, and other cultural phenomenon associated with English studies has been the dialogic relationship between teacher and student- - a fundamental feature of Eisner's education criticism. Thus his humanistic approach allowed me to explore and re-construct the nature of the CCCU English curricula.

\section{The Research Questions}

Two main research questions prompted this present study of CCCU curricula:

1. What was the nature and state of the undergraduate English major curriculum within Christian liberal arts colleges and universities, specifically among the member schools of the 2000-2001 CCCU? 
2. What evidence of Christian thought or influence appeared among the individual CCCU English major curricula, and so, within the aggregate curriculum?

Concomitant questions to the first research question addressed the content, claims, goals, structure, emphases and slights, patterns, strengths and weaknesses of the individual curricula and aggregate curriculum.

\section{The Population}

The 101 institutions holding full membership in the 2000-2001 CCCU constituted the population for the first step of this study, which was to classify any CCCU English major curricula offered $(N=98)$. For subsequent steps, 20 of those curricula provided the purposeful sampling, which received further description and analysis. Each institution represented a North American 4-year college or university, given to the liberal arts and sciences, whose mission purported the integration of the Christian faith and learning. Each American school had to hold regional accreditation.

Three main criteria for the purposeful sampling of curricula included the representation of (a) all major geographic regions of the United States, and the nation of Canada, (b) the spectrum of full-time enrollments among CCCU schools, from nearly 600 to nearly 3,200 , and (c) 10 or more of the various CCCU denominations and religious heritages. The CCCU institutions selected for the purposeful sampling were Bethel College (MN), Colorado Christian College (CO), Dallas Baptist University (TX), Dordt College (IA), Eastern Mennonite University (VA), Evangel University (MO), Gordon College (MA), Goshen College (IN), Houghton College (NY), King College (TN), Lee University (TN), Malone College (OH), Northwest Nazarene University (ID), Oklahoma Christian University (OK), Palm Beach Atlantic College (FL), Redeemer University 
College (ON, Canada), Seattle Pacific University (WA), Simpson College (CA), Westmont College (CA), and Wheaton College (IL).

\section{The Data Collection}

Academic catalogs and bulletins dated for 2001 or surrounding that date were requested through the postal mail, and follow-up requests through electronic mail. Eighty of the 101 publications were received through the postal service, whereas 21 were accessed through electronic web sites and their English curricula printed. Ninety-eight CCCU schools offered the English major and 3 did not. Of that total, 79 curricula (or nearly $81 \%$ ) appeared in publications whose dates included the year 2001; all catalogs and bulletins dated to within 1 year of 2001. Among the purposeful sampling of 20 catalogs and curricula, 18 (or 90\%) covered the 2000-2001 academic year, and all dated to within 1 year of that time.

\section{The Frameworks: Stewart's and Eisner's}

The two frameworks appropriated for this present study were (a) Stewart's (1989) qualitative categorization of English majors, a framework modified slightly for greater differentiation of categories, and (b) Eisner's $(1985,1991)$ education criticism, a means to examine and represent a work through four critical dimensions-description, analysis, interpretation, and thematics. Both Stewart's and Eisner's frameworks depended upon the research tool of close reading, a means "to discover the meaning of a text by focusing on the language of the text itself, its rhetoric, syntax, tone, and structure" (Encyclopedia of English Studies and Language Arts, 1994, p. 194). 
The current study modified Stewart's (1989) framework for categorizing the undergraduate English major; where he had classified a curriculum according to its number of literature courses, this study made a ratio of its literature courses to its total courses. Doing so allowed for a new category termed "Primarily Literature" which proved vital to classifying the CCCU curricula more specifically. The "Primarily Literature" type of English major appeared between Stewart's "Straight Literature" and "Somewhat Flexible" English major categories. Though Stewart had assigned several of the 194 major plans he studied to non-literature oriented categories, the current study found only 1 such curriculum among the 98 . All curricula within the purposeful sampling represented literature-oriented programs.

Though Stewart's (1989) framework provided the initial means to categorize the CCCU English curricula, it was not designed to do much more. Eisner's $(1985,1991)$ framework of education criticism offered a means compatible with Stewart's work and capable of producing further knowledge. Eisner's education criticism provided the means to illuminate the nature and state of the CCCU curricula much as a prism yields light by separating its dimensions. Eisner's framework in this current study allowed me to see elements of the CCCU curricula separately, yet to represent them wholly, much as an art connoisseur views and explicates the particulars of a work before interpreting it holistically to the public. The four dimensions of Eisner's education criticism permitted (a) the description of what constituted the CCCU English curricula and the aggregate curriculum, which I observed through close reading; (b) the interpretation of what I saw, from the perspective of having some expertise in curriculum and ability to recognize its 
meaning; (c) the evaluation of what I found and what I did not find, and in each case its import; and (d) the thematic patterns of meaning which I discerned in those curricula.

\section{Tools Designed to Apply Eisner's Framework}

The tools I designed to apply Eisner's framework to the CCCU curricula included four descriptive items: First Look Card, Claims Card, Content Organization Card, and Content Categories and Emphases Card. What these tools recorded helped to describe, analyze, and evaluate the $20 \mathrm{CCCU}$ English curricula which comprised the purposeful sampling.

The First Look Card allowed me to record initial information about each English major in standard form and order, including its total number of semester hours or their equivalent at the $200(0)$ level and higher, ratio of literature courses to the total number of English courses offered, resultant type according to Stewart's Modified Types of English Majors, its notable features, its strengths and weaknesses, and evidence of Christian thought. I placed comments and questions on the cards to help direct my thoughts during subsequent readings.

As I used this First Look Card during my initial, hour-long (or longer) close reading of each curriculum, I also gathered other information related to the English major. I noted three things: (a) the number of hours at 200(0) and higher needed for the English minor(s), (b) the number of hours needed for the English education major, and (c) any information about foreign and/or modern language requirements. I also checked the availability of English-related programs, such as writing, journalism, media, theater, and Teaching English as a Second Language (TESOL). 
The Claims Card represented the second descriptive tool which I designed and used to help identify curricular goals and objectives (sometimes) given in introductory statements. To develop this tool, I returned to the larger pool of CCCU curricula--now numbering 78 , since 20 had been removed for the purposeful sampling. From the $78 \mathrm{I}$ alphabetically chose approximately one of every seventh to eighth curriculum on the basis of its having an introductory statement.

From these 10 curricula I determined that four general claims recurred; that is, claims pertinent to all English courses, whether general studies claims, lower-level course claims, or higher-level major claims. These four I grouped in sets of their kernel phrases, such as "to communicate clearly" and "to communicate effectively." Six major-specific claims also recurred and proved more detailed. For instance, the claim "to prepare students for graduate studies" added specific possibilities for studies in "English," "related disciplines," or "other: ." Each set of claims and any subservient points that appeared on the Claims Card originated in the ten introductory statements.

Then I applied the Claims Card to the purposeful sampling of CCCU English curricula. To differentiate the levels of claims found, I made a grid for each to be coded "G" for goal, "OB" for objective, "NI for "not identified," and "I" for "indeterminable." This grid contained two columns, allowing me to record how the claim had been identified (if it had) by its introductory statement or sub-headlines, in comparison to my categorization of the claim.

The Content Organization Card, the third descriptive tool I designed, allowed me to identify the structure or organization of the English curricula in the purposeful sampling. Using McEwan's (1992) metaphors for English curricular structures, I made a 
checklist of likely possibilities including the traditional tripod, language growth, text/textuality, literature, and other models. Graff's $(1987,1992)$ core-and-periphery model and Waller's (1986) park-bench metaphor model were also noted as well as "Other" for any unknown structure. The Content Organization Card also provided for evidences of originality, vestiges of previous structures, transitions, and compromise. Under vestiges, the card directed me to include evidences of earlier curricula remaining in the current curriculum introduction, courses, non-course requirements, course scope and sequence, structures, and in "Other" miscellaneous ways.

Augmenting the Content Organization Card was the final tool I designed for this study - the Content Categories and Emphases Card. This identified those studies often present in the English curricula: literature, linguistics (including grammar and the history of the English language), rhetoric, composition, writing, journalism, and electronic media. I allowed, too, for other responses. For each of the five main studies listed, I added subcategories. Specific subcategories for literature included: English/British Literature, American Literature, World Literature, Literary Theory and/or Criticism, and Other Literature/Literary Courses.

\section{Tools Appropriated to Apply Eisner's Framework}

Two other tools I used in concert with Eisner's framework to analyze the CCCU English curricula were close reading and journaling. According to Edmonds (1994), close reading provides an analytical tool useful in "[discovering] the meaning of a text by focusing on the [character of its] language," whereas journaling provides a means of thinking-on-paper about the import and implications of a text (pp. $194 \& 682$ ). Both represent basic tools in English studies. Close reading had been crucial to my completion 
of the descriptive cards I designed; close reading also proved vital in my journaling about each curriculum in the purposeful sampling.

As I wrote each journal entry, I followed these 10 steps: (a) rereading the printed curriculum; (b) annotating it; (c) situating it by location, religious heritage, and full-time enrollment; (d) analyzing its introductory statement (when given) for purpose, function, and/or broad claims; (e) analyzing its goals and/or objectives (when given); (f) reflecting upon its format, structure, content, and appearance; (g) analyzing its scope and sequence of courses, especially for instructional levels; (h) asking questions about the curriculum, especially its structure and content; (i) evaluating its strengths and weaknesses, as well as other concerns; and (j) offering suggestions for changes to enhance its quality. I often returned to one or more of the steps to review my work.

When I had described and analyzed all 20 curricula of the purposeful sampling, I then applied close reading to these journal entries and color-coded their themes and patterns, focusing on the research questions. Through the color-coded materials, I made further observations in my journal and developed generalizations about the 20 curricula as an aggregate curriculum. I compared and contrasted these generalizations to what $\mathrm{I}$ had observed about the larger population when I had applied the First Look cards to all 98 English curricula. Finally, I stated my findings.

\section{Findings for Research Question 1: Nature and State}

Research question 1 inquired about the "nature and state of the undergraduate English curriculum" within member schools of the 2000-2001 CCCU, using seven subservient items identified as 1 a through $1 \mathrm{~g}$. 
Research question 1a concerned any evident correspondence between CCCU curricula (and their aggregate) and Stewart's (1989) Modified Categories of English Majors. Among the purposeful sampling of 20, 11 or $55 \%$ represented Stewart's Type 1.0 Straight Literature major; 4 or $20 \%$ the Type 1.5 Primarily Literature major; and 5 or $25 \%$ the Type 2.0 More Flexible major. Among the total population of 98 English curricula (issued by the 101 schools), 46 curricula or $47 \%$ constituted Type 1.0 majors; 30 or $31 \%$ were Type 1.5 curricula; and 18 or $18 \%$ were Type 2.0 . Four curricula or $4 \%$ represented Stewart's remaining three types. (Percentages were rounded off to nearest whole numbers.)

This study modified Stewart's categories by defining the four dominant types of English major curricula according to the percentage of course offerings assigned to literature. So, by definition, Type 1.0 Straight Literature curricula had $75 \%$ or more of their content given to literature; Type 1.5 had 64 to $74 \%$; and Type 2.0 had up to $63 \%$. These three types accounted for all 20 curricula in the purposeful sampling; moreover, they accounted for $98 \%$ of the population. The other types numbered so few among the population that they did not figure in the purposeful sampling.

These types compared reasonably to Stewart's (1989) initial classification of English curricula based on 194 curricula issued by "public and private universities" and colleges of nearly every type and size (p. 188). Of these 194 curricula, 11 were Type 1.0 Straight Literature majors; 107 were literature-dominated programs that would have been better differentiated as Type 1.5 Primarily Literature had Stewart used percentages to determine major classifications. I took the term directly from his report that "these [were] primarily literature programs" (Stewart's italics) which “[offered] significant courses in 
other fields" (pp. 189-190). Together, these types of literature-dominated curriculawhich correspond to Types 1.0 and 1.5 in Stewart's Modified System of Categorizationnumbered 118 and represented 64\% of Stewart's population $(N=194)$.

In this present study, Types 1.0 and 1.5 accounted for $75 \%$ of the sampling and $78 \%$ of the population. These higher figures than Stewart's (1989) probably reflected the greater homogeneity possessed by the CCCU population than that possessed by his study's population of secular, public and private colleges and universities. Only one among his 194 might have qualified for CCCU membership. In contrast, all CCCU members and their English curricula represented private, evangelical Christian schools. Nevertheless, the primary finding of my research aligned with Stewart's: both studies concluded that literature dominated the undergraduate English major curricula.

Whereas Stewart's (1989) work appeared amidst calls for reforming the English major (Elbow, 1990; Lawrence, 1988; Waller, 1986), this present study developed after the impetus for sweeping change had diminished (Fleishmann, 1995) through a decade of MLA sponsored case studies (e.g., Francus, 2001; Moffat, 2003; Murphy \& O’Shea, 1997; Schroeder, 1993). This current study appeared, too, after Applebee (1996), Berlin (1996), Raymond (1996), and Scholes (1998) had called for the reform of the English major through greater attention to rhetoric, metaphor, and textual studies. Still, the finding of this current study confirmed Stewart's (1989) observation that though "[canon] reform [was] becoming a significant question in a number of programs, the focus of the [major] still [fell] on the study of literature" (p. 193).

Broadly prescribing an English major with greater balance among literature, composition, and rhetoric, Stewart (1989, p. 194) stepped beyond classification to 
interpret and recommend. This current study, however, merely explored in order to represent and interpret the CCCU English curricula and its aggregate curriculum. Like Stewart, I have preferred a more rhetorically oriented curriculum, but in this study I did not prescribe what the CCCU English major should be; rather, I reported my observations and offered plausible interpretations.

The significance of my finding that literature dominated the CCCU English major curricula may be found among three differing interpretations. First, the CCCU English major curriculum represented a tried-and-true entity—an interpretation supportable by the professional reports issued throughout the final four decades of the $20^{\text {th }}$ century. Wilcox (1970) reported in his comprehensive survey that literature - that is, primarily English/British and American literatures - commanded the late 1960s undergraduate English curriculum. Cowan (1975) supported this through curricular profiles. Huber and Young (1986) concluded that the 1983-84 MLA survey found literature, specifically English/British and American literature, ranking foremost among "nine branches of English studies” (p. 41).

Harris (1986) and his MLA/ADE ad hoc committee studied 81 curricula and “[concluded] that the English major [had] changed little since 1965-68" (Lawrence, 1988, p. 14), much to the disgust of its members who campaigned for reform (Lawrence, 1988; Waller, 1986). Huber and Laurence (1989) interpreted the 1983-84 survey as further evidence that "English [program requirements stressed literature] courses in traditional areas and authors" (p. 45). Unfortunately, the 1991-92 MLA survey (Huber, 1996) failed to elucidate the state of English major; thus, at the start of the 1990s, Stewart's (1989) 
categorization of the English major curricula provided the clearest evidence for the continued hegemony of literature and the continued lack of change.

Thus, late $20^{\text {th }}$-century professional surveys and scholars attested to the literaturedominant and unchanging nature of the English major. This conclusion provided support for the first interpretation of my main observation; namely, that the CCCU English major represented a literature-based curriculum that had been tried and proven and, possibly, institutionalized.

The second interpretation would argue that the CCCU English curricula operated in the mainstream of undergraduate English. Support for this reading would be found in Stewart's (1989) study and the two professional English organization surveys mentioned above-the MLA/NCTE Wilcox (1970) national survey and the MLA 1983-84 surveys of the state of the English major. All three found that literature constituted the dominant element of the undergraduate English major curriculum. Since small schools had been omitted from the 1983-84 survey (Graff, 1992; Huber \& Young, 1986, p. 2), the nature of that major among evangelical colleges within Protestant Christianity remained unexamined. As the professional studies reported the decades-long dominance of literature in secular college and university English majors, and the present study found literature dominating the CCCU undergraduate English major, then the logical conclusion was that the CCCU English major reflected the mainstream curriculum.

The third interpretation would regard the 2001-2002 CCCU English curricula and its aggregate as dated in its emphasis on literature, but showing slight change in its attention to writing/composition/rhetoric. A "worn-and-dated" interpretation as the obverse of "tried-and-proven" can be supported particularly by such scholars as Waller 
(1986), Lawrence (1988), and Huber and Laurence (1989) after the 1983-84 MLA survey of the major and the 1985 MLA ad hoc committee study of 81 curricula. Datedness can be supported, too, by the call of Lloyd-Jones and Lunsford (1989), Elbow (1990), Berlin (1996), and Scholes (1998) for writing and rhetoric, rather than literature, to comprise the centrality of the English curriculum. Thus, the dated nature of the CCCU English curricula can be argued by the fact that literature dominated both its purposeful sampling and population even more than literature dominated Stewart's (1989) population. As noted above, Types 1.0 Straight Literature majors and Type 1.5 Primarily Literature majors represented $75 \%$ of the CCCU sampling and $78 \%$ of the population $(N=98)$. These figures exceeded Stewart's figure of $64 \%(N=194)$, but confirmed his finding.

Despite privileging literature, the CCCU English curriculum suggested change was occurring through the auspices of writing/composition/rhetoric. This study observed the expanded roles of writing and rhetoric in both Types 1.5 and 2.0 curricula, especially in the latter. Elective courses increased in both, as did writing programs among the two types. Findings about electives and writing programs appear below under points $1 \mathrm{e}$ and 1f, so here I will simply note that 11 of the 20 curricula in the purposeful sampling had writing programs by 2001 compared to 5 in 1997 . This pointed to the apparent change wrought by writing/composition in the English major.

In sum, each of the three interpretations given above helps to explain the state of the CCCU English major curriculum at the start of the $21^{\text {st }}$ century: It reflected the triedand-proven, literature-dominant major offered by secular and larger institutions; it also reflected the mainstream curriculum which Stewart (1989) established in the initial 
categorization of the major; but, as it appeared more than a decade after his study, it had a dated, inordinate emphasis on literature.

Research question $\mathbf{1 b}$ concerned any claims, assumptions, and themes that appeared among the CCCU English curricula. This current study found that $20 \%$ of the purposeful sampling $(N=20)$ and over $18 \%$ of the population $(N=98)$ did not articulate any claims for their English majors-a revelation that Laff (1998) would rue for its lack of transparency about what an English student major learns.

Among those sampled curricula which did articulate them, three recurring claims arose. First, the English major claimed to prepare students for graduate studies. Nine of the 20 sampled curricula, or $45 \%$, claimed such preparation; 3 or $15 \%$ specified that the studies might be in English or other disciplines. Second, 10 curricula, or $50 \%$, claimed that the English major prepared students for careers and/or professions, specifically in the law, ministry, journalism, medicine, business, media (i.e., publishing and broadcasting), and other areas. Third, 6 curricula, or $30 \%$, claimed that the major prepared students to teach English as their content area at the secondary level. Notably, these claims occurred at approximately the same frequencies among Types 1.0, 1.5, and 2.0 curricula.

Beside those recurring claims, two repeated assumptions characterized the sampling of CCCU English curricula. First, the major had to justify itself as a means toward future careers and professions-including teaching. Second, the major had to relate directly to students' future achievements. Both these assumptions anticipated the two recurring themes identified by this current study: (a) that English graduates entered careers and professions involving persuasive thinking, and (b) that they pursued careers 
and professions that served humanity. These included the law, the ministry, journalism, and education.

The significance of the findings on question $1 b$ must include the impact that the lack of identified claims has on student apprehension of English as a discipline or field and of its curriculum, as well as the issues and opportunities English offers. The omission of claims by one of every five curricula in the sampling (and nearly that in the population) pointed to the need to educate students beyond the content areas of English into its professional issues and opportunities. This need reflected Graff's argument (1990) that students learn to debate current issues; further, it suggested that better marketing of the major should occur within the academic catalog-a tool which by $2000-2001$ commonly appeared on CCCU institutional web sites. Finally, this lack of published claims suggested that any assessment of the English major may not have related directly to the published curriculum. These possibilities invite further research.

The claims that the sampled curricula prepared students for graduate studies in various disciplines and areas, especially in secondary teaching, raised another significant possibility - that the CCCU English curriculum was susceptible to external programs and pressures. This has been a long-lasting concern. When Wilcox (1970) issued the first national survey of undergraduate English, he noted faculty concern that general education program demands detracted from the ability to offer higher level English major courses (p. 121). Thirty years later, the 2001 MLA report on teaching, while calling for the promotion and recognition of excellence at all levels of English instruction, protested the susceptibility of the English curriculum to outside demands especially by legislators (p. 231). The relevance of both these concerns needs to be researched among the CCCU 
English curriculum to assess the effect of its roles as a service curriculum to general education and to teacher certification.

Question $1 \mathrm{~b}$ yielded another significant finding related to the theme of English graduates serving in law, ministry, journalism, and teaching. As these professions demand persuasive thinking and articulate expression, graduates entering them must possess high-level rhetorical skills. Rhetoric, however, received less attention than literature among the purposeful sampling of CCCU English curricula. Among the purposeful sampling's three majors types, and in all its curricula, required courses in rhetoric ranged from zero to one. Only the Type 2.0 More Flexible English majors offered courses in argumentation, debate, and composition/rhetoric theory. Those courses offered were electives, ranging each from zero to one. Thus, the CCCU curricular support for English graduates entering persuasive professions proved slight.

Research question 1c concerned goals, aims, and/or objectives evident in the CCCU English curricula. Further, it asked how any given goals were articulated and what orientations they suggested. The lack of published claims noted above (for 1b) accounts for the paucity of identified goals and their frequency. Twelve goals appeared among the sampling of 20 curricula, representing intellectual goals for two distinct categories: service goals and English major goals. The former applied to all courses, particularly those serving the larger academic community (e.g., freshman composition). The gist of these six service goals called for students to think clearly and critically, and to express themselves clearly and effectively—especially in writing.

Goals for the English major dealt with literature and language more than writing/composition/rhetoric or other English studies. Three goals called for students to 
enhance their understanding of certain literatures: English/British, American, and world literature. One goal called for students to analyze texts, and two called for them to enhance their knowledge of the English language system and its history. As the service goals proved broad and general, so did the major goals.

Significantly, no goal for the English major specifically addressed writing/composition/rhetoric; nor did any treat the newer aspects of English studies such as film studies and other media. The English major aims emphasized two branches or legs of the traditional tripod model of the English discipline: literature (the privileged subject) and language (that is, grammar and linguistics). Goals for the third leg, writing/composition/rhetoric, appeared among the service category. This finding for the purposeful sampling of $20 \mathrm{CCCU}$ English curricula pointed to the aggregate curriculum to be tradition-bound and, thus, oriented to literature.

This condition prevailed despite the work of Elbow (1990), Berlin (1996), Applebee (1996), and Scholes (1998) calling for reform of the English undergraduate curriculum through the aegis of rhetoric. But the condition showed that the CCCU English curriculum at the start of the $21^{\text {st }}$ century appeared very similar to the condition of the English curriculum among secular colleges and universities late in the $20^{\text {th }}$ century (Huber, 1990, 1996; Stewart, 1989, 1990).

Research question $1 \mathrm{c}$ also concerned any objectives that appeared within the purposeful sampling of CCCU English curricula. The current study found statements misidentified as objectives though they actually represented goals, but found no subservient statements representing actual objectives. That is, no true objectives appeared in the traditional Tylerian behavioral sense or in Eisner's more descriptive sense (Madus 
\& Kellaghan, 1992, pp. $123 \& 130$ ). This omission of objectives, unlike the omission of goals, did not seem particularly noteworthy since academic catalogs seldom reach this level of specificity. Much more significant was the paucity of aims or goals for the major (noted above).

Finally, question $1 \mathrm{c}$ concerned the articulation of goals and objectives. This aspect of the sampled curricula yielded little information except for the diversity of expression among the goals. Though this current study included several examples of goal statements to suggest that difference, the diversity also meant goals had to be reduced to their kernel meanings for classification and counting. Excerpted goals did reveal that the CCCU English curricula contained occasional errors in grammar and syntax, indicating the need for careful editing and proofing.

Research question 1d addressed the organizational models or structures of the sampled individual CCCU English curricula, the structure of their aggregate curriculum, any apparent vestiges of earlier models, and any evidence of organizational transition or innovation. Two organizational or structural models accounted for all 20 curricula in the purposeful sampling: (a) the traditional tripod of the English major drawn as literature, grammar and/or linguistics, and composition (Elbow, 1990), and (b) the more recent core-and-periphery model of the major conceived as a required core of traditional literature courses circled by a growing periphery of electives in minority literatures, writing/composition/rhetoric, linguistics, media, and other studies (Graff, 1987, 1992).

Nine curricula in the purposeful sampling $(N=20)$ or $45 \%$ fit the traditional tripod model; of these, 7 were Stewart's Modified Type 1.0 and 2 were Type 1.5 English major curricula. Type 1.0 had a minimum of $75 \%$ literature courses, and Type 1.5 a 
minimum of $65 \%$. This finding reflected the tradition of literature representing the privileged post of the tripod (Elbow, 1990; Waller, 1986). Eleven curricula, or 55\%, had the newer core-and-periphery structure wherein literature dominated core course requirements whereas linguistics, composition/writing, and other electives--especially minority literature electives-occupied more peripheral positions. (Research question 1e, below, addresses content; here, the focus is on structure.) Five of the 11 represented Type 2.0 More Flexible English Majors, while 4 were Type 1.0 Straight Literature and 2 were Type 1.5 Primarily Literature English programs.

Although Types 1.0 and 1.5 English major curricula appeared in both structural models, Type 2.0 among the purposeful sampling appeared only as core-and-periphery curricula. That is, no Type 2.0 More Flexible English Major curriculum was structured in the traditional tripod form. This finding proved accurate not only for the purposeful sampling, but for the population of this present study. Among the population of $98 \mathrm{CCCU}$ English curricula, only one Type 2.0 major curricula was structured in the traditional tripod form.

These findings may support the possible interpretations given for question 1a; namely, that the CCCU English aggregate curriculum represented (a) a tried-and-proven major dominated by literature and structured mainly in the traditional tripod which has characterized the undergraduate English curriculum since the Wilcox survey (1970); (b) a mainstream curriculum whose traditional structure reflected the mainstream emphasis on literature (Stewart, 1989); or, (c) a dated curricula showing slight change from the rule of literature through the traditional tripod model to a more flexible content arranged in a core-and-periphery structure. The fact that no Type 2.0 More Flexible English curricula 
among the sampling, and only one among the population, was structured in the traditional tripod supported the interpretation that the CCCU curriculum showed slight changing, for the further an English curriculum departed from being a Type 1.0 Straight Literature major, the more it tended to have a core-and-periphery structure.

Research question 1d also concerned vestiges of earlier models of English; among the sampling there appeared remnants of what Graff termed the field coverage model or the historical coverage of literature model $(1987,1992)$. This schema divided literary content into periods and/or eras; featured major authors; focused on literary movements; and in larger universities, ordered the hiring of faculty according to those categories (Graff, 1987). Vestiges of this model proved plentiful throughout the purposeful sampling, especially among literature-dominated Types 1.0 and 1.5 curricula wherein historically oriented literature courses characterized the 300 and 400 levels. Examples included surveys such as "British Literature: 1800 to the Present"; major eras such as "Victorian Literature"; major movements such as "Romanticism"; and major authors such as Shakespeare.

This present study found that Types 1.0 and 1.5 English major curricula, however organized, tended to require more field or historical coverage courses than the Type 2.0. This finding was congruent with Stewart's (1989) study. Further, it suggested that Types 1.0 and 1.5 English major curricula promulgated the traditional privileging of literature by assigning historical coverage literature courses to higher instructional levels. That is, junior and senior level courses steeped in the traditional canon appeared to preserve the traditional hegemony of literature and the status quo in the English major. Changes that may have occurred, especially in composition/writing and minority literatures at the 200 
level, often signified less importance. Type 2.0 majors, more flexible in their content, had fewer historical coverage courses to suggest such a status-quo strategy. From this observation, I inferred that Type 2.0 curricula-structured almost universally as coreand-periphery and characterized by fewer historical eras, movements, and major authors courses - pointed to the CCCU curricula and its aggregate curriculum developing some flexibility.

Research question 1e concerned the content of the CCCU English curricula and its aggregate curriculum, asking what categories (if any) received emphasis and what had little or no attention. The findings given below reflect the purposeful sampling of 20 English major curricula. Each major type (1.0, 1.5, and 2.0) will be discussed separately below, in the order of emphases, slights, and omissions, before the aggregate curriculum is considered.

The Type 1.0 Straight English Major programs revealed three emphases: genre, American literature, and British/English literature. Genre courses had the greatest range of required courses, from 0 to 6 , probably because genre offerings often provided a combination of American and British/literatures (for example, a course in the $19^{\text {th }}$ century novel). Another factor in genre courses proving most numerous was the occasional recasting of a historical era course as a genre offering (such as a course treating the realistic novel).

For American literature, the second emphasis among the Type 1.0 curricula, the range of required courses extended from 0 to 3 and the range of electives from 2 to 5 . Survey courses represented the usual requirements in this literature, and all such surveys appeared at the 200 and 300 levels. Seven of the 11 Type 1.0 curricula (or nearly $64 \%$ ) 
required at least one survey of American literature, and 6 (for nearly 55\%) required two such surveys.

For British/English literature, the third emphasis, the range of required courses went from 0 to 4 . These requirements, like those for American literature, tended to be survey courses offered at the 200 and 300 levels. Among the 11 Type 1.0 curricula, 5 to 6 (or $46 \%$ to $60 \%$ ) required at least one 200 - or 300 -level survey in British/English literature. Variations in different tracks of the major accounted for varying percentages (which were rounded off). Besides a required survey(s) in this literature, a Shakespeare course at the 300 level represented another common requirement among 5 to 6 (or $46 \%$ to $60 \%$ ) of the 11 Type 1.0 majors. Another factor adding to the emphasis on British/ English literature was that it had the greatest range of elective courses-from 0 to 7 .

The 11 Type 1.0 curricula slighted several studies including linguistics, rhetoric, and writing. For linguistics, required courses ranged from 0 to 1 each for three courses: grammar, descriptive linguistics, and history of the English language. Electives ranged similarly except for descriptive linguistics, ranging from 0 to 4, thanks to English-related programs in ESL, TESOL, and TEFL. Type 1.0 curricula also slighted rhetoric and writing. Required courses in both composition and advanced composition ranged from 0 to 1; elective courses had the same range. Required courses in creative writing ranged from 0 to 2, as did electives. These slights conformed to the traditional triangle of the English curriculum emphasizing literature and slighting linguistics and rhetoric (and/or composition and writing).

Thus, the slighting of two literary-related courses appeared unexpected. Type 1.0 curricula gave literary theory/literary criticism and the senior seminar/capstone course 
scant attention. As required courses, both ranged from 0 to 1 ; as electives, they ranged the same. As their inclusion in the curriculum would likely have enhanced the critical discussion of literature, so the reason(s) for their being slighted needs to be determined by further research.

Omissions by Type 1.0 curricula reflected their literary nature: no skill-oriented, practical courses were required. No old- or new-media courses, no editing courses, no internships were required. Electives in news writing, editing, and interning ranged from 0 to 1 among these 11 curricula.

For the 11 Type 1.0 Straight Literature English Majors among the purposeful sampling, the above emphases, slights, and omissions signified the hegemony of the traditional English paradigm wherein literature reigned. They showed that $55 \%$ of the purposeful sampling $(N=20)$ closely resembled the English curriculum described by the Wilcox report $(1970,1973)$, by the 1983-84 MLA survey, and by Stewart's (1989) study. The Type 1.5 Primarily Literature English Major, numbering four among the 20 sampled curricula, emphasized English/British and American literatures as did the Type 1.0 plans, but without their emphasis on genre. Required courses in British/English literature ranged from 2 to 3; electives ranged from 1 to 3. Similarly, required courses for American literature numbered 2 and electives ranged from 1 to 2 . One world literature course was required, and 1 to 2 other such courses appeared as electives.

The ranges for both a required course and elective in literary theory/literary criticism went from 0 to 1 . No genre-based courses were required, although genre electives ranged from 2 to 4 . Literature surveys, rather than the genre courses characteristic of Type 1.0 curricula, characterized Type 1.5 programs which offered 
numerically more and characteristically more diverse courses. Literature courses accounted for both the greater number and diversity of Type 1.5 curricula offerings. National and ethnic literatures included Canadian literature and African American literature, whereas literary studies included women writers, topics, themes, and authors. All represented electives only. No Christian-related literature courses were required, but the topics course presumably allowed for such a study. The capstone/senior seminar, as in the Type 1.0 curricula, was more likely to be an elective (ranging from 0 to 2) than a requirement (ranging from 0 to 1 ).

Type 1.5 English curricula showed little difference from Type 1.0 among the categories of linguistics, rhetoric, and writing, but gave greater opportunity for practical, career-related experiences. Required internships ranged from 0 to 1 , but electives ranged from 0 to 3 . An elective practicum ranged from 0 to 1 , and elective travel courses ranged from 0 to 2. One newer course also appeared among electives: an introductory to English studies course, ranging from 0 to 1 .

These differences from Type 1.0 curricula suggested that the Type 1.5, with their greater number of electives and greater diversity as well as their attention to career and travel offerings, appeared more flexible and perhaps more attractive to potential student majors. Nevertheless, the Type 1.5 major still represented literature-dominated plans.

Type 2.0 More Flexible English Majors, numbering 5 of 20 in the purposeful sampling, revealed three characteristics, namely the dominance of British/English and American literatures, multiplication of minority literatures, and proliferation of electives. Also notable was the increase of writing courses, but these tended to be optional. British/English and American literatures still remained the foundation of Type 2.0 
curricula; as required courses, the former ranged from 2 to 4 , and the latter from 2 to 3 . As electives, their ranges were greater. British/English literature ranged from 2 to 7 , and American from 0 to 4 . World literature as a required course extended from 0 to 2 , and measured the same as an elective. In contrast to Types 1.0 and 1.5 curricula, the 2.0 More Flexible English Major was more likely to require these traditional literature courses.

Minority literatures multiplied as electives among Type 2.0 curricula. African American literature headed six courses with a range of 0 to 3. Asian American, Ethnic American, and Native American literatures followed each with a range of 0 to 1. Women's literature as an elective ranged from 0 to 2 . Only one minority literature-a combination course - appeared among required courses, and it ranged from 0 to 1 .

Other literature courses figured mostly among electives except one given to Shakespeare and one thematic course. The Shakespeare offering ranged from 0 to 3, and the themes course from 0 to 1 . Electives of genre and of Shakespeare courses topped the list of electives, ranging respectively from 0 to 4 and 0 to 5 . Other electives, listed with their ranges in parentheses, included literature courses in Great Britain (0 to 1); topics in literature (0 to 2); literature and film (0 to 1); and, various Christian-related courses with similar ranges. The Shakespearean numbers reflected the 1991-92 MLA Survey findings that this course remained vital to the English curriculum (Huber, 1996; Thomas, 2000).

The proliferation of literature electives among Type 2.0 curricula included two career-oriented courses not offered by Types 1.0 or 1.5 plans: a practical criticism course at the sophomore level and a senior project. As required courses each ranged from 0 to 1 . Added to literary theory/literary criticism which ranged from 0 to 1 , and the 
capstone/senior seminar course with the same range, they effected an emphasis on career and professional preparation that did not appear among the other curricular types.

Type 2.0 curricula significantly expanded course offerings in writing. Creative writing, which had figured as one of two electives in Types 1.0 and 1.5 curricula, now headed a list of 17 elective courses. Added were single genre courses, such as writing poetry; media writing courses, such as film scripting; discipline-related courses, such as science writing; career-oriented courses, such as writing for public relations; mediaoriented options, such as magazine writing and publishing; and electronic media writing. Also, practical opportunities increased with the addition of student publishing laboratories. These represented nearly all electives with small ranges; 16 of the 17 electives ranged from 0 to 1 . The only required course among the list was creative writing, which both as a requirement and elective also ranged from 0 to 1 .

The significant increase of electives in writing and literature among Type 2.0 curricula related to their characteristic, core-and-periphery structure (noted under section 1d above). Multiple additions swelled a periphery of electives circling a core of required, traditional literature courses - that is, in British/English, American, and world literatures. This reflected Graff's (1990) observation that electives proliferate in the periphery of core-and-periphery-structured English majors.

The findings for the content of the three types of curricula pointed to this situation among the CCCU English curricula:

1. They represented literature-based curricula, just as Stewart (1989) found of secular college English curricula.

2. They slighted linguistics, rhetoric, and composition. 
3. They had two primary structures, with the traditional tripod organization characteristic of the Type 1.0 Straight Literature major and the core-and-periphery organization dominant among the Type 2.0 More Flexible major. The Type 1.5 Primarily Literature major appeared in both structures.

4. They offered limited practical experiences, but Types 1.5 and 2.0 gave greater attention than Type 1.0 to internships, practicum experiences, and travel opportunities.

5. They offered writing courses as electives rather than requirements, with Type 2.0 offering a plethora of writing electives geared to professional career needs (e.g., Writing for Public Relations).

6. Type 2.0 with its increase in writing and minority literature electives exhibited the "swollen periphery" typical, according to Graff (1990), of its core-and-periphery model.

Interpreting these findings, I would argue that the CCCU aggregate English curricula remained stolidly traditional in its conception of English as the discipline of literature (primarily), linguistics and composition (secondarily). The evidence of the addition of minority literatures and writing courses as electives, first apparent in Type 1.5 but pronounced in Type 2.0 curricula, represented minimal curricular reaction to the change in the literary canon, revival of rhetoric, and career demands. This reading posited slight, superficial change from Type 1.0, the traditional 1960ish curriculum, to Type $1.5 \mathrm{a}$ transitional curriculum, to Type 2.0 the more flexible and responsive-to-current-demands curriculum. However, at the core, all three remained literature curricula with slightly modifying electives. 
The findings invited at least one alternative interpretation: the reading that the CCCU English curricula offered a proven, unified curriculum reflective of traditional offerings. Certainly it reflected what Stewart (1989) confirmed by his qualitative study; what Waller (1986) protested as dated; and what Cowan (1975), Peck (1973) and most importantly Wilcox $(1970,1973)$ reported of the curricula at a variety of colleges and universities. The CCCU English curricula, like those offered by secular colleges and universities, represented a literature major which responded to the literary canon's bursting by adding elective studies in other cultures' literatures as well as in American minority literatures. It adjusted to the recent revival of rhetoric by providing elective writing courses. It responded to contemporary technology by providing writing courses as well as internships in the workplace. Most importantly, in light of those changes, this stable curriculum provided what Armstrong and the English Coalition (1990) called for in the English major-“"coherence" (p. 30).

This coherence, I would argue, failed to address the contemporary situation of English which gives greater attention to the writing and interpreting of texts (Berlin, 1996; Scholes, 1998); to diverse methods of critical interpretation (Armstrong, 1990; Graff, 1990); and to critical dialogue or conversations, conflicts and issues (Applebee, 1996; Armstong, 1990; Graff, 1990). To the CCCU English curricula, I would apply the observation made by Wheaton College Professor Ryken (1991) about critical methodologies; he averred that the English curricula "[should] intersect at virtually every turn with critical traditions from Aristotle through the latest critical fashion" (p. 299). Through those intersections, issues, or debates, as Armstrong (1990) and Graff (1990) claim, coherence could be constructed. 
Research question 1f dealt with patterns apparent within the content of the CCCU English curricula. Four of the seven patterns discerned have been discussed previously (under "structure"), namely that the: (a) Type 1.0 Straight Literature English Major was structured in the traditional tripod privileging literature but slighting linguistics and composition; (b) Type 1.5 Primarily Literature English Major appeared in both the tripod and the core-and-periphery structures, and also privileged literature; (c) Type 2.0 More Flexible English Major almost universally depended on the core-andperiphery form; and (d) Type 2.0, while it still represented a literature-dominant curriculum, offered many career-oriented electives in writing.

Three other patterns appeared, the first representing the most significant; that is, the increased number of writing programs (minors, tracks, etc.). Among the purposeful sampling $(N=20)$, five curricula definitely had offered writing programs by the 1997 1998 academic year, whereas by 2001,11 provided such programs. Of these, 4 had incorporated writing as an emphasis or track within the English major. Two programs, however, had been separated from the English major and made discrete, writing major programs. Seven writing minors, concentrations, and/or emphases among six different schools appeared independent of the English major.

This pattern among the sampling held true within the total population of CCCU schools with English majors $(N=98)$. Of the 47 curricula providing writing programs by 2003, 12 had not had any such programs 6 years earlier. The addition of writing majors, minors, tracks, concentrations, and/or emphases proved no respecter of enrollment: Colleges with 600-some students and universities with 5,000-plus were expanding their curricula in writing at roughly the same rate. 
This increase in writing programs at the century's turn suggested that change, however slight, was transpiring within CCCU English curricula. Writing was acquiring leverage among the Types 1.5 and 2.0 curricula. Among the purposeful sampling $(N=$ 20), 5 CCCU schools had English/Writing majors or English majors with writing tracks or emphases by the 2002-2003 academic year.

The responsibility for these English/writing programs presumably fell mainly to full-time English faculty, possibly increasing their teaching loads. Only one institution among the purposeful sampling $(N=20)$ identified writing faculty separately from its English faculty; two institutions listed its part-time writing faculty. Evidently, writing by the early 2000 s had not acquired leverage in the hiring of academic personnel.

Another pattern, but lesser in its scope, emerged: "Shakespeare" remained a required course for 8 of the 20 curricula sampled (that is, $40 \%$ ). In every case, this requirement appeared at the 300 or 400 level of instruction. Among the sampling, Type 2.0 curricula, the More Flexible English Major plans, were the most likely to require this course $(N=3$ of 5). Among Type 1.0 Straight Literature English Major plans, 4 of 11 required "Shakespeare," and among Type 1.5 Primarily Literature English Major plans one of four. Among the sampling, 19 of 20 or $95 \%$ of the curricula offered a course entitled Shakespeare, 13 at the junior level and 6 at the senior. This figure compared closely with the $97.3 \%$ of 4-year institutions reported by the 1991-92 MLA survey as offering a Shakespeare course (Huber, 1996, p. 37). These findings indicated that the Shakespeare course remained a staple course among the CCCU English curricula, but not necessarily a required course. 
The last notable pattern was the concentration of courses at the junior level (i.e., 300 level) of instruction, a feature characterizing all three types of English majors within the purposeful sampling of CCCU curricula $(N=20)$. For the Type 1.0 Straight Literature curricula, course offerings by levels averaged six sophomore courses, 15 junior courses, and nine senior courses. (Figures were rounded off.) For Type 1.5 Primarily Literature curricula, offerings averaged seven sophomore-, 18 junior-, and six senior-level courses. For Type 2.0 More Flexible curricula, offerings averaged eight sophomore-, 28 junior-, and six senior-level courses.

The burgeoning of junior-level courses among Type 2.0 related to the plethora of elective courses, mainly in writing but also in minority literatures, reported (above) for question 1e. To a limited degree, this explanation accounted for the Type 1.5 showing many 300-level offerings, but another factor figured in-and into Type 1.0 plans, which also showed this imbalance. This was the propensity of historical coverage courses, such as Victorian Literature, to carry junior-year status. Twelve curricula in the purposeful sampling $(N=20)$ had period courses at the 300 and 400 levels, especially at the former. Beside specific period courses, survey courses covering several eras also tended to be placed at the junior level. So did amalgamated courses such as "Milton and the Seventeenth Century."

Finding historical coverage courses commonly being blended with related courses, such as "Milton and the Seventeenth Century" and "Chaucer and Medieval Literature," I wondered if period and major author courses from the traditional canon were being preserved as higher level electives. If so, the CCCU English curricula were experiencing the phenomenon Waller (1986) identified as the "park-bench" principle. 
Paraphrased, it claims that in an expanding curriculum, the more contemporary and demanded courses will edge out the older, less popular fares until the latter disappear (p. 33). This experience, I believe, partly accounted for there being many more junior courses in contrast to sophomore and senior offerings. That is, historical periods and major authors courses were being consigned to the 300 level before being expunged from the CCCU English curriculum.

A notable observation about patterns and the CCCU curricula concerned English as a second language (ESL), and/or the teaching of English as a second or foreign language (TESOL, TESL, TEFL, or TEFOL). Nine of the 20 schools whose English curricula constituted the purposeful sampling offered ESL and/or TESOL (etc.) courses and/or programs. Two schools offered major programs in TEFL; one university provided major programs in both TESOL and TEFOL; and five offered minors in these studies. In the CCCU population, 34 of the 101 institutions provided TESOL and/or TESOL-type courses. Two implications for the English curricula were that TESOL-type offerings provided career and mission opportunities to augment the English major; they also served in some schools as competition for its students and, perhaps, for its resources.

Research question $1 \mathrm{~g}$ concerned the curricular weaknesses and strengths apparent among the purposeful sampling of CCCU English curricula. The nature of this question meant that some observations reported below reiterated points given above. The weaknesses of the CCCU curricula: From highest to lowest percentages, there were five leading weaknesses characterizing the three types of curricula which compromised the purposeful sampling of 20 . The foremost concern was the lack of goals, aims which characterized all three types: $45 \%$ lacked such statements, with the highest incidence of 
omission shown by Type 1.5 curricula, followed by Type 1.0 and then Type 2.0 plans. Question 1c (above) reported on the paucity of goals and the two kinds of goals that did appear-service-oriented and major-specific goals.

The second leading weakness proved to be the inadequate attention to writing, composition, and rhetoric shown by $40 \%$ of the sampling $(N=20)$, and especially by Type 1.0 Straight Literature English Major curricula. This reflected both the literature dominance and the career/practical skill de-emphasis of Type 1.0 majors. Question 1e (above) discussed the de-emphasis of writing opportunities among Type 1.0 and 1.5 curricula, as well as the proliferation of elective courses within Type 2.0 curricula.

The third leading weakness was the imbalance of junior-level course offerings, a problem characterizing all three curricular types. Among the purposeful sampling $(N=$ 20), $35 \%$ showed 300 level courses averaging from more than two to more than four times those of the 200- and 400-level courses (as shown by Point 1f, above). This phenomenon appeared pronounced for the Type 2.0 More Flexible English Major curricula, due to the plethora of writing electives accreting in the periphery of this coreand-periphery model. Type 1.5 Primarily Literature English Major curricula shared the same phenomenon and cause, but to a lesser extent. Type 1.0 Primarily Literature English Major curricula had the least evidence of imbalance, and yet it appeared in nearly one of five Type 1.0 curricula.

The fourth major weakness occurred among $35 \%$ of the three curricular types: The de-emphasis on linguistics, including the grammar and the history of the English language, was noted above under question 1e. This situation appeared most evident among Type 1.5 plans, followed by Type 2.0 plans. Type 1.0 majors fared better; only 
$27 \%(N=11)$ appeared weak in linguistics, grammar, and history of the English language.

The fifth major weakness represented another slighting-this time of studies in composition and rhetoric. Among all three types of curricula in the purposeful sampling $(N=20), 30 \%$ gave evidence of this de-emphasis. Exhibiting this problem most were Type 2.0 curricula, followed by Type 1.5 and Type 1.0 plans (as discussed above under question 1e).

Significantly, four of the five most pronounced weaknesses shared by the three types of English curricula involved the continual dominance of literature among these CCCU plans. Their de-emphasis of writing, linguistics, and composition/rhetoric, I think, reflected the persistent power of the traditional tripod model which characteristically slighted these studies to privilege literature. Even Type 2.0 curricula, all structured as core-and-periphery models in the purposeful sampling and all but one in the population, had core requirements reflecting the traditional tripod. What Stewart (1989) concluded on the nature of the curricula in his study also applied to these CCCU curricula: They remained literature curricula. In my opinion, this meant they remained dated and in need of reform.

Further evidence of their dated nature appeared through additional weaknesses, including the lack of attention to non-Western, minority, and multicultural literatures, as well as to practical and career-related courses. These problems reflected the changing nature of English itself, from the traditional tripod-structured discipline to the more diverse field of English studies which shows greater concern for writing, composition and 
rhetoric, linguistics, and other English-related studies such as film, electronic media, and culture.

The plethora of writing electives among Type 2.0 More Flexible English Major curricula reflected efforts, I believe, to accommodate this changing nature of English. I based my interpretation on these factors: (a) Writing and minority literature courses, both emphases in English studies, swelling the periphery of this core-and-periphery structured type (as noted under questions $1 \mathrm{~d}$ and 1e, above); (b) Programs in career-related and/or professional writing (rather than composition/rhetoric) increasing $20 \%$ within the purposeful sampling $(N=20)$ between 1997 and 2000. I viewed the plethora, the two new emphases, and the increase in writing programs as signs of change.

Other interpreters of the English major outside the CCCU, however, see such changes as threats to a long-proven curriculum; Balch and Brasor (2001) decried the increased diversity of the curriculum as "the fragmentation of the major" through "'nonfoundational"" courses (pp. 61 \& 63). Their usage of "non-foundation," however, was one example of their extreme bias: "non- foundational" referred to any course whose "subject matter was largely composed on literature written with fifty years of the offering date" (p. 63). Balch and Brasor would undoubtedly applaud the CCCU Types 1.0 and 1.5 curricula for stressing traditional literature.

Fleishman (1995) wrote a less polemical assessment of recent changes within English, in general, and within its curriculum, when he criticized "literary studies [for not being] a unified field [and for not being] organized around a single center . . " (p. 810). He could hardly say this of the CCCU Types 1.0 and 1.5 curricula, wherein literature 
remained the center and the focus. Like Balch and Brasor (2001), Fleishman would approve of their being founded and focused on literature.

While I appreciated such concern for curricular focus, I considered the CCCU faculty behind Types 1.0 and 1.5 curricula to have been myopic in making literature the sole lens for students to view the English field. Agreeing with Stewart (1990) in his afterthoughts article, I argue that "an undergraduate English major [student] should have some knowledge of all kinds of work going on in the field" (p. 130). Other lens and foci, including recent metaphors, could have provided CCCU students the means to see the different subjects within the English field. Such lens included the English curriculum conceived metaphorically as dialogue or conversation (Applebee, 1996), as rhetoric (Berlin, 1996), as textual studies (Scholes, 1998), as theater (Raymond, 1996) or as some combination of these approaches (Yood, 2003).

The strengths of the CCCU English curricula represented two types: content and opportunity strengths. Based on the purposeful sampling of 20, four content strengths and one opportunity strength characterized these plans. Content strengths included first the dominance of literature, especially of British/English and American literatures for all three types of English major curricula found (i.e., Types 1.0, 1.5, and 2.0). The second was the inclusion of literary history/theory or literary criticism among $80 \%$ of the purposeful sampling $(N=20)$. Among the Type 1.0 Straight Literature curricula within that sampling, 8 of 11 or $73 \%$ required this study. Among the Type 1.5 Primarily Literature curricula, three of four or $75 \%$ required it, and among the Type 2.0 More Flexible curricula, three of five or $60 \%$ required a literary history/theory or criticism 
course. These figures directly supported the previous strength. (Percentages were rounded off.)

The third content strength appeared in the use of a senior-level capstone course for several purposes: to integrate faith and learning, to promote higher critical thinking skills, to promote research skills, and to debate English issues. For Type 1.0 curricula, 6 of 11 plans or $55 \%$ required the capstone course, and 1 offered it as an elective. This fact reflected the type's adherence to the traditional canon of literature. Type 1.5 curricula, however, had a low incidence of senior seminars: only one of four or $25 \%$ included such a course and did so as an elective. Supporting this low figure was a second purposeful sampling of six Type 1.5 curricula (not in the first purposeful sampling) in which one of six or $17 \%$ listed a capstone course. The explanation for the relative non-usage of capstone courses by Type 1.5 curricula lies, I believe, in this type's provision for more options than the first type. Finally, and in contrast, Type 2.0 curricula gave the capstone/seminar greater attention than did the other types: three of five Type 2.0 curricula or $60 \%$ required the capstone/seminar course. The explanation for this lies, I think, in their students' need to synthesize knowledge gleaned among this type's more diverse courses.

This third content strength contrasted directly to a weakness previously cited: that is, the significant increase in writing programs contrasted to the inadequate attention given to writing. Briefly, between 1997 and 2001, the number of CCCU schools with writing programs grew from 5 to 11 for a $120 \%$ increment. (Additional details appeared under research question 1f.) The majority of these programs were integrally related to the English major as minors, alternative tracks, and/or concentrations. Two schools, though, 
offered writing majors independent of their English majors. Although writing majors provided competition for students, funds, and other resources, their presence indirectly may have strengthened English courses. This certainly represented a possibility wanting further research.

One opportunity strength characterized the CCCU English curricula: its careeroriented practicum and internship offerings. Twelve of the 20 curricula or $65 \%$ of the purposeful sampling included one or both courses. Predictably, as the curriculum types became less literature-dominated, they appeared more likely to offer practical experience. Sixty-five percent of Type 1.0 Straight Literature curricula $(N=11)$ offered one or more of these practical, career-oriented courses; $75 \%$ of Type 1.5 Primarily Literature curricula $(N=4)$ did so; and all Type 2.0 More Flexible curricula $(N=5)$ provided practicum and internship experiences.

Interpreting the significance of these CCCU English curricula content strengths, I observed the second and third strengths served especially to undergird these literaturedominated curricula. The inclusion of literary theory/criticism among 14 of the 20 sampled curricula suggested the enhancement of students' critical, literary skills. So did the use of the seminar/capstone course as a means to integrated knowledge, synthesize and evaluate texts, and to critique critical theories, and literary issues. Together, these two content strengths intensified the centrality of literature among the CCCU English curricula.

Increased attention to writing courses and programs constituted the third content strength, suggesting change occurring within the dated, aggregate English curriculum of the CCCU. Writing, that is, career and professional writing, represented a new emphasis 
which developed among electives in the aggregate curriculum between 1997 and 2001. Writing proved subordinate to the English major in 10 of 12 curricula (among the purposeful sampling of 20); in two, writing represented independent majors. I regarded the heavy subordination of writing to English as the English major's reluctant but shrewd response to paradigmatic change. That is, the CCCU aggregate English major curriculum accommodated limited change through its writing courses without being significantly changed in its essential nature-at least, not yet significantly changed. The English major allowed the limited presence of writing, but consigned it to the periphery of its literature curriculum where career-oriented writing courses could attract students to the English major itself. This interpretation invited further research.

Perhaps, however, the new emphasis on writing reflected other late- $20^{\text {th }}$-century factors such as the revival of rhetoric, the back-to-the-basics, and the Writing-Across-theCurriculum movements. Perhaps the arguments of English curricularists Berlin (1996) and Scholes (1998), who advocated organizing the English major on the basis of writing and interpreting texts, influenced the CCCU curricula. These possibilities also warranted further research.

The last strength evident represented one of opportunity: the offering of careeroriented internships and practicum courses. While the three types of English curricula in the purposeful sampling $(N=20)$ provided such opportunities, Type 2.0 More Flexible English Majors were the most likely to offer them. All five Type 2.0 curricula provided internships and/or practicum courses, mostly at the junior and senior levels. These courses appeared with the writing electives at the periphery of the major, signifying their remove from the literary core. 


\section{Findings for Research Question 2: Evidence of Christian Thought}

Research question 2.0 concerned the evidence of Christian thought among the CCCU English major curricula and their aggregate, as gauged through a purposeful sampling $(N=20)$. Overt evidence at the curricular level represented four categories of courses stressing Christianity, that is, they focused on (a) biblical content, (b) integration of Christian thought and English content, (c) major authors associated with Christianity from the $5^{\text {th }}$ through the $19^{\text {th }}$ centuries, or (d) major authors associated with Christianity during the $20^{\text {th }}$ century. Other authors associated with Christianity received less focused attention within survey, genre, and period courses (as discussed below).

Biblical content, the first category, consisted of courses in which the Holy Bible in translation served as the primary text studied, with concentration given to its literary qualities, especially form and genre. Course titles in this category included "Literary Forms of the Bible" and "Biblical Narrative" as well as "The Bible as Literature." Five such courses, all at the junior level, appeared among the curricula samples. Four were within Type 1.0 Straight Literature major curricula, a fact consistent with Ryken's observation that "formalist criticism . . . continues to be at the center of the academic study of literature" (1991, p. 1). Notably, no such course appeared within Type 2.0 More Flexible major curricula, which represented the least literature-dominated of the three types found in the purposeful sampling.

The integration of Christian thought and English studies, the second category of evidence, appeared among seven curricula or $35 \%$ of the purposeful sampling $(N=20)$. Courses charged with integrating faith and literature or faith and writing carried diverse titles, but five of the seven represented seminar/capstone courses. All but one appeared at 
the senior level. Such courses occurred among all three kinds of English major curricula found in the sampling, but four of the seven appeared in the Type 1.0 Straight Literature major curricula. This fact juxtaposed readily with Barge's (1994) claim that literature provided an exemplary milieu for "'integrative pluralism," which called for students to meld texts compatible to, challenging to, and hostile to Christian perspectives (p. 44).

The third category of evidence had courses devoted to and named for individual authors associated with Christian thought from the $5^{\text {th }}$ through the $19^{\text {th }}$ centuries. Within the purposeful sampling of CCCU curricula $(N=20)$, eponymous courses numbered 21 and included 11 given to Milton, 8 to Chaucer, 1 to Johnson, and 1 to Augustine. All 21 courses had junior- or senior-level status. Type 1.0 Straight Literature curricula $(N=11)$ were most likely to offer these courses: $64 \%$ offered a.Milton course and $63 \%$ a Chaucer course. Two Type 1.5 Primarily Literature major curricula listed Milton courses, but only 1 a Chaucer study. Three of four Type 2.0 Primarily Literature major curricula had Milton courses, and two had Chaucer courses. Type 2.0 More Flexible major curricula had two of five offering Milton courses and two Chaucer courses; that meant $60 \%$ of these plans had one or both studies. (Percentages were rounded off.) Two caveats, however, figured in any interpretation of these percentages: First, several curricula generalized their course descriptions and thus omitted specific names of writers; second, several "topics" courses and seminars varied their subject matter from term to term.

The fourth category of evidence represented courses devoted to and named for individual authors or specific groups associated with Christian thought during the $20^{\text {th }}$ century. Four of the seven such courses appearing within the purposeful sampling $(N=$ 20) had incorporated the name of C. S. Lewis in their titles and/or subtitles. Another cited 
"Oxford Christians," which per force implied his name. Five of these seven courses were found within the Type 2.0 More Flexible major curricula; the other two appeared within the Type 1.0 Straight Literature major curricula. All seven represented electives, and six of the seven represented junior or senior levels. Notably, eponymous courses were given to Lewis alone and to no other author.

Finding four categories of recurring evidence to Christian thought among the CCCU English curricula surprised me, as I had not anticipated several types of evidence or as many courses dealing with Christian texts and/or ideas. Further, the average number of such courses per curricular type suggested a balance of offerings among them. Type 1.0 curricula $(N=11)$, the most literature-dominated kind, averaged two courses each; Type $1.5(N=4)$ averaged one course each; and Type $2.0(N=5)$, the curricula offering the most options, averaged two courses each. (Averages were rounded off to the nearest whole numbers.)

Type 1.0 curricula proved most likely to offer biblical content and pre- $20^{\text {th }}$ century major authors courses, whereas Type 2.0 were most likely to offer $20^{\text {th }}$-centuryauthors-courses, particularly C. S. Lewis-oriented courses. These two observations seemed consistent with the respective character of the curricular types. Type 1.0, which reflected the traditional literary canon, offered the greatest number of earlier, major authors courses. Type 1.5, which also reflected the old canon, followed suit and offered several earlier, major authors courses. Type 2.0 curricula, with its plethora of electives in literature and writing, offered both earlier major authors courses and $20^{\text {th }}$-century major authors courses. Understandably, Type 2.0 listed the most $20^{\text {th }}$-century-authors courses, 
focused particularly on C. S. Lewis. These observations seemed consistent with the natures of the differing types.

But the nature of Christian evidence within the aggregate curriculum, based on the recurring evidence of these four categories, pointed to a disturbing condition: namely, the perpetuation of one tradition of Christianity and literature. The CCCU English curriculum perpetuated a British-Christian tradition, oriented to the literature of Puritan John Milton and Anglo-Catholic C. S. Lewis, stressing texts written in different eras by white, middle-class males. This aspect of the CCCU aggregate English curriculum perpetuated both the traditional canon and British conceptions of Christianity.

Support for this interpretation came not only from the evidence offered, but also from possibilities omitted. First, the recurring courses of pre- $20^{\text {th }}$-century major authors were named for two of the three major poets of the British English language: Milton and Chaucer. Recurring courses for the $20^{\text {th }}$ century were given almost universally to C. S. Lewis. Those were the chosen. The omitted or minimized represented salient figures in the history of Christian thought and literature, including Augustine whose early medieval text On Christian Doctrine articulated the principles for a Christian interpretation of texts; Hildegard von Bingen's medieval Christian drama; Dante, the late medieval Italian poet and author of The Divine Comedy; Pascal, the $18^{\text {th }}$-century French philosopher and author of Pensees (Thoughts); Dostoevsky, the $19^{\text {th }}$-century Russian novelist; Hawthorne, the $19^{\text {th }}$-century American novelist; and Emily Dickinson, the late- $19^{\text {th }}$-century American poet. Although these and other writers associated with Christianity did appear elsewhere in the CCCU curriculum, especially through survey and genre courses, they did not receive the stress given Chaucer, Milton, and C. S. Lewis. 
Thus, non-British writers associated with Christian thought were omitted from the recurring evidence to Christianity among the CCCU English curriculum. So, too, were women writers associated with the faith, whether foreign such as the medieval abbess Heloise, or British such as the modern mystery writer and Christian apologist Dorothy L. Sayers. Dissenters and/or heterodox authors, such as British novelist George Eliot (Mary Ann Evans) or American poet Emily Dickinson, did not figure in eponymous courses or any other recurring evidence. These exclusions meant that the old traditional canon provided the primary perspective for $\mathrm{CCCU}$ students to view literary texts interrelating with Christian thought.

Through this outdated perspective, students risked developing critical myopia, what Lundin called a "monistic and monological" perspective of literature, when they need "interpretive practices that are polyphonic and dialogical" including literary theory and/or criticism grounded in Christian thought (2002, p. 104). Students risked missing the varied challenges posed by other literature-related studies including hermeneutics, cultural studies, and language theory studies. Such potential losses attended the CCCU English curriculum for circumscribing Christian thought to the old canon of literature.

\section{Conclusions}

I offer the following conclusions about the English major aggregate curriculum offered by the 2000-2001 member institutions of the CCCU:

1. It represented a literature-based curriculum much like the traditional tripodstructured English major of the late 1960s, comprised of literature, composition, and linguistics, and emphasizing British/English and American literature. Its alternative 
structure, a core-and-periphery organization, retained much of the traditional tripod literature requirements in the core while the periphery expanded with electives.

2. It offered three types of majors, each literature based and representative of Stewart's (1989) modified categories: (a) Type 1.0 Straight Literature in which literature comprised $75 \%$ or more of the content; (b) Type 1.5 Primarily Literature, in which it comprised $65 \%$ to $74 \%$; and (c) Type 2.0 More Flexible, in which it comprised less than $65 \%$.

3. It tended not to state its purposes and goals, but differentiated the few given as service goals for general studies (e.g., to think critically) or major goals (e.g., to apply a critical approach); its introduction, however, claimed to prepare students for (a) graduate studies, (b) careers and/or professions, especially in law, ministry, journalism, media, medicine, and business, and (c) to teach English for their content area in secondary school.

4. It slighted writing, composition, rhetoric, and linguistics (i.e., grammar and English language history); it also slighted non-Western, multicultural, and minority literatures.

5. It showed increased attention to writing courses and programs. Between 1997 and 2002 , the curriculum saw a $34 \%$ increase in its writing programs, usually as tracks, concentrations, or minors subordinate to the English major.

6. It suffered a marked imbalance among levels of courses, having many more junior-level courses than sophomore or senior courses. This phenomenon was caused by adding of elective courses in writing and minority literatures, and assigning traditional canon and field coverage courses (e.g., the Victorian novel) to the 300 level. 
7. It undergirded its main content strength in literature through two, upper-level courses: the literary criticism (or, literary history/theory) course, and the capstone/ seminar. Both offered students opportunities to synthesize and evaluate their literary studies, and to integrate them with Christian faith.

8. It revealed four categories of courses concerned with Christian thought: (a) biblical content courses, (b) integration of Christian thought and English studies, (c) major authors associated with Christianity from the $5^{\text {th }}$ through the $19^{\text {th }}$ centuries, and (d) major authors associated with Christianity during the $20^{\text {th }}$ century. It emphasized Milton, Chaucer, and C. S. Lewis (in that order), but Lewis dominated the 20th century. Christian thought in this curriculum appeared through the lens of British history and culture, and from the perspectives of white-male, British writers.

\section{Recommendations for Further Study}

To CCCU institutions and similar schools, I make several recommendations. Curriculum review should be a continuous activity among English faculty; constant study should address the theoretical foundation, nature, claims, purposes, goals, content, challenges, and opportunities of one's curriculum. That represents the global recommendation of this study, but more specific recommendations for further study appear in the following questions:

1. What impact does the increased emphasis on writing hold for the English major, from global concerns such as the basis of the major to practical concerns as the effects of added writing courses on faculty teaching loads? 
2. How might the English major further its impact on the "helping professions" (e.g., law, ministry, medicine), which English graduates commonly pursue? How might studies in rhetoric (such as argumentation) help prepare students for those professions?

3. What changes would make the curriculum more (a) goal conscious, (b) up-todate, and (c) inclusive in its content?

4. What perspectives of Christian thought should the English major offer its students?

\section{Final Remarks}

This study closes first with a challenge to English faculty among the CCCU, and last with one to English educators throughout Christian higher education. I urge CCCU faculty to revise their major curricula by (a) replacing the traditional triangle with coreand-periphery or other contemporary models, (b) reducing the dominance of British/ English and American literatures, (c) offering more courses in world, world English, and other literatures, (d) strengthening the roles of composition, professional writing, and rhetoric, (e) strengthening linguistics through TESOL studies, (f) giving greater attention to media studies, and (g) providing more diverse perspectives of Christian thought.

Finally, I urge all English educators within Christian higher education to study the nature and state of their undergraduate major curricula; to determine what theories serve as their bases; to evaluate curricular particulars; and, especially, to determine how their curricula reflect Christian thought. I challenge them to provide a more complete picture of English studies, to analyze the aggregate nature of the major curricula more deeply, and to probe the next salient research question: What should be the Christian college English major curriculum, and what should it accomplish? 


\section{APPENDIX A}

MEMBERS OF THE COUNCIL FOR CHRISTIAN COLLEGES AND UNIVERSITIES, THEIR LOCATIONS, RELIGIOUS AFFILIATIONS, AND

UNDERGRADUATE ENROLLMENTS

\begin{tabular}{|c|c|c|c|}
\hline $\begin{array}{l}\text { Member } \\
\text { Institution }\end{array}$ & State / Region & \begin{tabular}{|l} 
Religious \\
Affiliation or $^{\text {Heritage }}$ \\
He $^{\mathbf{a}}$
\end{tabular} & $\begin{array}{l}\text { Undergraduate } \\
\text { Enrollment }^{\mathbf{b}}\end{array}$ \\
\hline Abilene Christian U. & TX/Southwest & Churches of Christ & 4,078 \\
\hline Anderson U. & IN / Midwest & Church of God (IN) & 1,988 \\
\hline Asbury C. & KY / South & Wesleyan-Arminian & 1,317 \\
\hline Asuza Pacific U. & CA / West & Wesleyan & 3,092 \\
\hline Belhaven C. & MS / South & Presbyterian & 1,317 \\
\hline Bethel C. & IN / Midwest & Missionary Church & 1,552 \\
\hline Bethel C. & KS / West & Mennonite & 477 \\
\hline Bethel C. & MN / Midwest & $\begin{array}{l}\text { Baptist General } \\
\text { Conference }\end{array}$ & 2,721 \\
\hline Biola U. & CA / West & Interdenominational & 2,564 \\
\hline Bluffton C. & $\mathrm{OH} /$ Midwest & $\begin{array}{l}\text { General Conference } \\
\text { Mennonite Church }\end{array}$ & 999 \\
\hline Bryan C. & TN / South & Interdenominational & 521 \\
\hline California Baptist U. & CA / West & $\begin{array}{l}\text { Southern Baptist } \\
\text { Convention }\end{array}$ & 1,618 \\
\hline Calvin C. & MI / Midwest & $\begin{array}{l}\text { Christian Reformed } \\
\text { Church }\end{array}$ & 4,218 \\
\hline Campbell U. & NC / Southeast & Baptist & 2,201 \\
\hline Campbellsville U. & KY / South & $\begin{array}{l}\text { Kentucky Baptist } \\
\text { Convention }\end{array}$ & 1,548 \\
\hline Cedarville U. & $\mathrm{OH} /$ Midwest & $\begin{array}{l}\text { General Association } \\
\text { of Regular Baptist } \\
\text { Churches }\end{array}$ & 2,762 \\
\hline $\begin{array}{l}\text { College of the } \\
\text { Ozarks }\end{array}$ & MO / Midwest & Presbyterian & 1,429 \\
\hline Colorado Christian U. & $\mathrm{CO} /$ West & Interdenominational & 1,786 \\
\hline Cornerstone U. & MI / Midwest & $\begin{array}{l}\text { General Association } \\
\text { of Regular Baptist } \\
\text { Churches }\end{array}$ & 1,508 \\
\hline Covenant C. & GA / Southeast & $\begin{array}{l}\text { Presbyterian Church } \\
\text { in America }\end{array}$ & 1,049 \\
\hline Crichton C. & TN / South & Interdenominational & 896 \\
\hline Cumberland $\mathrm{C}$. & KY / South & Baptist & \\
\hline Dallas Baptist U. & TX/Southwest & Baptist & 3,150 \\
\hline Dordt C. & IA / Midwest & $\begin{array}{l}\text { Christian Reformed } \\
\text { Churches }\end{array}$ & 1,430 \\
\hline
\end{tabular}




\begin{tabular}{|c|c|c|c|}
\hline East Texas Baptist U. & TX/South & \begin{tabular}{|l|} 
Baptist General \\
Convention of Texas \\
\end{tabular} & 1,301 \\
\hline Eastern C. & PA / East & $\begin{array}{l}\text { American Baptist } \\
\text { Churches in the USA }\end{array}$ & 1,902 \\
\hline Eastern Mennonite U. & VA / Southeast & Mennonite Church & 1,099 \\
\hline Eastern Nazarene C. & MA / Northeast & $\begin{array}{l}\text { Church of the } \\
\text { Nazarene }\end{array}$ & 1,341 \\
\hline Erskine C. & SC / Southeast & $\begin{array}{l}\text { Associate Reformed } \\
\text { Presbyterian Church }\end{array}$ & $\overline{519}$ \\
\hline Evangel U. & MO / Midwest & Assemblies of God & 1,525 \\
\hline Fresno Pacific U. & CA / West & Mennonite Brethren & 875 \\
\hline Geneva C. & PA / East & $\begin{array}{l}\text { Reformed } \\
\text { Presbyterian Church } \\
\text { of North America }\end{array}$ & 1,877 \\
\hline George Fox U. & OR / Northwest & Evangelical Friends ${ }^{b}$ & 1,677 \\
\hline Gordon C. & MA / Northeast & Interdenominational & \\
\hline Goshen C. & IN / Midwest & Mennonite Church & 1,084 \\
\hline Grace C. & IN / Midwest & \begin{tabular}{|l|} 
Fellowship of Grace \\
Brethren Churches \\
\end{tabular} & 923 \\
\hline Grand Canyon U. & AZ / Southwest & Southern Baptist & 1,534 \\
\hline Greenville C. & IL / Midwest & $\begin{array}{l}\text { Free Methodist } \\
\text { Church }\end{array}$ & 1,049 \\
\hline Hope International U. & CA / West & $\begin{array}{l}\text { Christian Church/ } \\
\text { Churches of Christ }\end{array}$ & 793 \\
\hline Houghton C. & NY / East & The Wesleyan Church & 1,380 \\
\hline Houston Baptist U. & TX / Southwest & $\begin{array}{l}\text { Baptist General } \\
\text { Convention of Texas }\end{array}$ & 1,799 \\
\hline Howard Payne U. & TX / Southwest & \begin{tabular}{|l|} 
Baptist General \\
Convention of Texas \\
\end{tabular} & 1,496 \\
\hline Huntington $\mathrm{U}$. & IN / Midwest & $\begin{array}{l}\text { United Brethren in } \\
\text { Christ }\end{array}$ & 904 \\
\hline Indiana Wesleyan U. & IN/Midwest & The Wesleyan Church & 4,898 \\
\hline John Brown U. & AR / South & Interdenominational & 1,421 \\
\hline Judson C. & AL / South & Southern Baptist $^{b}$ & 308 \\
\hline Judson C. & IL / Midwest & Baptist & 1,110 \\
\hline Kentucky Christian C. & KY / South & $\begin{array}{l}\text { Churches of Christ } \\
\text { and Christian } \\
\text { Churches }\end{array}$ & 564 \\
\hline King C. & TN / South & $\begin{array}{l}\text { Presbyterian/ } \\
\text { Reformed }\end{array}$ & 587 \\
\hline Lee University & TN / South & Church of God (TN) & 3,155 \\
\hline Le Tourneau U. & TX/Southwest & Interdenominational & 2,523 \\
\hline Lipscomb U. & TN / South & Churches of Christ & 2,317 \\
\hline Malone C. & $\mathrm{OH} /$ Midwest & $\begin{array}{l}\text { Evangelical Friends } \\
\text { Church }\end{array}$ & 1,949 \\
\hline Messiah C. & PA / East & Brethren in Christ & 2,735 \\
\hline
\end{tabular}




\begin{tabular}{|c|c|c|c|}
\hline $\begin{array}{l}\text { MidAmerica } \\
\text { Nazarene U. }\end{array}$ & ID / West & $\begin{array}{l}\text { Church of the } \\
\text { Nazarene }\end{array}$ & 1,173 \\
\hline Milligan C. & TN / South & Nondenominational & 796 \\
\hline Montreat C. & NC / Southeast & Presbyterian/Reformed & 992 \\
\hline $\begin{array}{l}\text { Mount Vernon. } \\
\text { Nazarene U. }\end{array}$ & $\mathrm{OH} /$ Midwest & $\begin{array}{l}\text { Church of the } \\
\text { Nazarene }\end{array}$ & 1,843 \\
\hline North Greenville C. & SC / Southeast & $\begin{array}{l}\text { South Carolina Baptist } \\
\text { Convention }\end{array}$ & 1,220 \\
\hline North Park U. & IL / Midwest & $\begin{array}{l}\text { Evangelical Covenant } \\
\text { Church }\end{array}$ & 1,619 \\
\hline $\begin{array}{l}\text { Northwest Christian } \\
\text { C. }\end{array}$ & OR / Northwest & $\begin{array}{l}\text { The Christian Church/ } \\
\text { Christian Church/ } \\
\text { Churches of Christ }\end{array}$ & 418 \\
\hline Northwest C. & WA / Northwest & Assemblies of God & 972 \\
\hline $\begin{array}{l}\text { Northwest Nazarene } \\
\text { C. }\end{array}$ & ID / Northwest & $\begin{array}{l}\text { Church of the } \\
\text { Nazarene }\end{array}$ & 1,114 \\
\hline Northwestern C. & IA / Midwest & $\begin{array}{l}\text { Reformed Church in } \\
\text { America }\end{array}$ & 1.219 \\
\hline Northwestern C. & MN / Midwest & Nondenominational & 1,744 \\
\hline Nyack C. & $\mathrm{NY}$ & $\begin{array}{l}\text { Christian and } \\
\text { Missionary Alliance }\end{array}$ & 1,424 \\
\hline Oklahoma Baptist U. & OK / Southwest & $\begin{array}{l}\text { Baptist General } \\
\text { Convention of } \\
\text { Oklahoma } \\
\end{array}$ & 2,098 \\
\hline $\begin{array}{l}\text { Oklahoma Christian } \\
\text { U. }\end{array}$ & OK / Southwest & The Wesleyan Church & 1,701 \\
\hline $\begin{array}{l}\text { Oklahoma Wesleyan } \\
\text { U. }\end{array}$ & OK / Southwest & Church of Christ & c. $2,100^{\mathrm{b}}$ \\
\hline Olivet Nazarene U. & IL / Midwest & $\begin{array}{l}\text { Church of the } \\
\text { Nazarene }\end{array}$ & 1,850 \\
\hline Oral Roberts U. & OK / Southwest & Nondenominational & 3,064 \\
\hline $\begin{array}{l}\text { Palm Beach Atlantic } \\
\text { C. }\end{array}$ & FL / Southeast & Baptist & 1,838 \\
\hline $\begin{array}{l}\text { Point Loma Nazarene } \\
\text { U. }\end{array}$ & CA / West & $\begin{array}{l}\text { Church of the } \\
\text { Nazarene }\end{array}$ & 2,350 \\
\hline $\begin{array}{l}\text { Redeemer University } \\
\text { C. }\end{array}$ & (ONTARIO) & Reformed Christian & 605 \\
\hline Roberts Wesleyan C. & NY / East & Free Methodist Church & 1,149 \\
\hline Seattle Pacific U. & WA / Northwest & Free Methodist Church & 2,636 \\
\hline Simpson C. & CA / West & $\begin{array}{l}\text { Christian and } \\
\text { Missionary Alliance }\end{array}$ & 971 \\
\hline Southern Nazarene U. & OK / Southwest & $\begin{array}{l}\text { Church of the } \\
\text { Nazarene }\end{array}$ & 1,652 \\
\hline $\begin{array}{l}\text { Southern Wesleyan } \\
\text { U. }\end{array}$ & OK / Southwest & The Wesleyan Church & 1,472 \\
\hline Southwest Baptist U. & MO / Midwest & $\begin{array}{l}\text { Missouri Baptist and } \\
\text { Southern Baptist } \\
\text { Conventions }\end{array}$ & 2,801 \\
\hline
\end{tabular}




\begin{tabular}{|l|l|l|c|}
\hline Spring Arbor C. & MI / Midwest & Free Methodist Church & 2,139 \\
\hline Sterling C. & KS / West & $\begin{array}{l}\text { Presbyterian Church } \\
\text { (USA) }\end{array}$ & 424 \\
\hline Tabor C. & KS / West & Mennonite Brethren & 538 \\
\hline Taylor U. & IN / Midwest & Interdenominational & 1,897 \\
\hline The King's C. & (Alberta) & Interdenominational & 526 \\
\hline The Master's C. & CA / West & Baptist (Fundamental) & 969 \\
\hline Trevecca Nazarene U. & TN / South & $\begin{array}{l}\text { Church of the } \\
\text { Nazarene }\end{array}$ & 1,004 \\
\hline Trinity Christian C. & IL / Midwest & Reformed Christian & 723 \\
\hline $\begin{array}{l}\text { Trinity International } \\
\text { U. }\end{array}$ & IL / Midwest & $\begin{array}{l}\text { Evangelical Free } \\
\text { Church of America }\end{array}$ & 964 \\
\hline Trinity Western U. & (British Columbia) & $\begin{array}{l}\text { Evangelical Free } \\
\text { Church }\end{array}$ & 2,379 \\
\hline Union U. & TN / South & $\begin{array}{l}\text { Tennessee Baptist } \\
\text { Convention }\end{array}$ & 1,931 \\
\hline U. of Sioux Falls & SD / Midwest & American Baptist & 946 \\
\hline Vanguard U. & CA / West & Nondenominational & 1,289 \\
\hline Warner Pacific U. & OR / Northwest & Church of God (IN) & 645 \\
\hline Warner Southern C. & FL / Southeast & Church of God (IN) & 844 \\
\hline Western Baptist C. & OR / Northwest & Baptist & 683 \\
\hline Westmont C. & CA / West & Nondenominational & 1,323 \\
\hline Wheaton C. & IL / Midwest & Nondenominational & 2,338 \\
\hline Whitworth C. & WA / Northwest & $\begin{array}{l}\text { Presbyterian Church } \\
\text { (USA) }\end{array}$ & 1,780 \\
\hline William Tyndale C. & MI / Midwest & Nondenominational & 637 \\
\hline Williams Baptist C. & AR / South & $\begin{array}{l}\text { Arkansas Baptist State } \\
\text { Convention }\end{array}$ & 637 \\
\hline ISource Member's academic bulletin or catal & Ogunles Otherwise indicated \\
\hline
\end{tabular}

${ }^{a}$ Source: Member's academic bulletin or catalog unless otherwise indicated.

'Source: Peterson's Christian Colleges \& Universities (2000). 


\title{
APPENDIX B
}

\section{REQUEST FOR ACADEMIC CATALOG}

[Bethel College Letterhead Stationery]

\author{
Bethel College \\ 1001 W. McKinley Ave. \\ Mishawaka, IN 46544 \\ October 9, 2001 \\ [Name of Admissions Representative] \\ [Name of College or University] \\ [Address of that School] \\ [City, State Zip Code]
}

Dear Admissions Representative:

Please send me a copy of the academic bulletin or catalog for [Name of the School] which includes the 2000-2001 curriculum. For my doctoral dissertation at Andrews University (MI), I plan to describe and analyze the English curricula of all the full-time member institutions belonging to the Council for Christian Colleges and Universities, If you cannot send a bulletin dated for that academic year, please choose one as close to the 2000-20001 school year as possible.

I plan to categorize the types of English majors found among the 101 full-time members of the CCCU, and to describe and analyze a purposeful sampling of $20 \mathrm{CCCU}$ English curricula.

Though my study concerns CCCU English curricula, I have not asked that organization to fund my research .

Thank you for your consideration.

Maralee S. Crandon

Associate Professor of English

(Tel. 574-257-3361) 


\section{APPENDIX C}

STEWART'S MODIFIED TYPES OF ENGLISH MAJOR CURRICULA AMONG THE 2000-2001 CCCU MEMBERS

\begin{tabular}{|c|c|c|}
\hline $\begin{array}{l}\text { CCCU Member Institution } \\
\text { Catalog Year(s) }\end{array}$ & $\begin{array}{l}\text { Stewart's Modified } \\
\text { Type } \\
\text { of English Curricula } \\
\end{array}$ & $\begin{array}{l}\text { Percentage }^{a} \text { of Curricula } \\
\text { Consisting of Literature } \\
(200-400 \text { Levels })\end{array}$ \\
\hline $\begin{array}{l}\text { Abilene Christian University } \\
(2001-2002)\end{array}$ & 1.5 Primarily Literature & 65 \\
\hline $\begin{array}{l}\text { Anderson University } \\
(2000-2002)\end{array}$ & 1.0 Straight Literature & 79 \\
\hline $\begin{array}{l}\text { Asbury College } \\
(2001-2002)\end{array}$ & 1.0 Straight Literature & 84 \\
\hline $\begin{array}{l}\text { Azusa Pacific University } \\
(2000-2001)\end{array}$ & 2.0 More Flexible & $63-74^{c}$ \\
\hline $\begin{array}{l}\text { Belhaven College } \\
(2001-2002)\end{array}$ & 1.0 Straight Literature & 86 \\
\hline $\begin{array}{l}\text { Bethel College (IN) } \\
(2001-2002)\end{array}$ & 2.0 More Flexible & 60 \\
\hline $\begin{array}{l}\text { Bethel College (KS) } \\
(2001-2002)\end{array}$ & 1.0 Straight Literature & $70-80^{c}$ \\
\hline $\begin{array}{l}\text { Bethel College (MN) } \\
(2001-2002)\end{array}$ & 2.0 More Flexible & 60 \\
\hline $\begin{array}{l}\text { Biola University } \\
(2001-2002)\end{array}$ & 2.0 More Flexible & 62 \\
\hline $\begin{array}{l}\text { Bluffton College } \\
(2001-2002)\end{array}$ & 2.0 More Flexible & 50 \\
\hline $\begin{array}{l}\text { Bryan College } \\
(2002-2004)\end{array}$ & 1.5 Primarily Literature & 65 \\
\hline $\begin{array}{l}\text { California Baptist University } \\
(2001-2002)\end{array}$ & 1.0 Straight Literature & 84 \\
\hline $\begin{array}{l}\text { Calvin College } \\
(2001-2002)\end{array}$ & 1.5 Primarily Literature & 71 \\
\hline $\begin{array}{l}\text { Campbell University } \\
(2002-2003)\end{array}$ & 1.0 Straight Literature & 94 \\
\hline $\begin{array}{l}\text { Campbellsville University }{ }^{b} \\
(2001-2003)\end{array}$ & 1.0 Straight Literature & 87 \\
\hline $\begin{array}{l}\text { Cedarville College } \\
(2002-2003)\end{array}$ & 1.0 Straight Literature & 76 \\
\hline $\begin{array}{l}\text { College of the Ozarks } \\
(2000-2002)\end{array}$ & 1.0 Straight Literature & 83 \\
\hline $\begin{array}{l}\text { Colorado Christian University } \\
(2001-2002)\end{array}$ & 1.0 Straight Literature & 76 \\
\hline
\end{tabular}




\begin{tabular}{|c|c|c|}
\hline $\begin{array}{l}\text { Cornerstone U. } \\
\text { ( }\end{array}$ & & \\
\hline $\begin{array}{l}\text { Covenant College }{ }^{b} \\
(2002-2003)\end{array}$ & 1.0 Straight Literature & 82 \\
\hline $\begin{array}{l}\text { Crichton College } \\
(2001-2003)\end{array}$ & 1.0 Straight Literature & 82 \\
\hline $\begin{array}{l}\text { Cumberland College }{ }^{b} \\
(2002-2003)\end{array}$ & 1.0 Straight Literature & 76 \\
\hline $\begin{array}{l}\text { Dallas Baptist University } \\
(2002-2004)\end{array}$ & 1.0 Straight Literature & 78 \\
\hline $\begin{array}{l}\text { Dordt College } \\
(2001-2002)\end{array}$ & 1.5 Primarily Literature & 71 \\
\hline $\begin{array}{l}\text { East Texas Baptist University } \\
(2001-2002)\end{array}$ & 1.5 Primarily Literature & 72 \\
\hline $\begin{array}{l}\text { Eastern College } \\
(2001-2002)\end{array}$ & 1.5 Primarily Literature & 72 \\
\hline $\begin{array}{l}\text { Eastern Mennonite University } \\
(2001-2002)\end{array}$ & 1.0 Straight Literature & 83 \\
\hline Eastern Nazarene & & \\
\hline $\begin{array}{l}\text { Erskine College } \\
(2002-2003)\end{array}$ & 1.0 Straight Literature & 85 \\
\hline $\begin{array}{l}\text { Evangel University } \\
(2000-2003)\end{array}$ & 1.5 Primarily Literature & 69 \\
\hline $\begin{array}{l}\text { Fresno Pacific University } \\
(2002-2003)\end{array}$ & 1.5 Primarily Literature & 73 \\
\hline $\begin{array}{l}\text { Geneva College } \\
(2001-2003)\end{array}$ & 1.0 Straight Literature & 81 \\
\hline $\begin{array}{l}\text { George Fox University } \\
(2001-2002)\end{array}$ & 4.0 Miscellaneous & -- \\
\hline $\begin{array}{l}\text { Gordon College } \\
(2001-2003)\end{array}$ & 1.0 Straight Literature & 75 \\
\hline $\begin{array}{l}\text { Goshen College } \\
(2001-2003)\end{array}$ & 2.0 More Flexible & 55 \\
\hline $\begin{array}{l}\text { Grace College } \\
(2001-2002)\end{array}$ & 1.0 Straight Literature & 80 \\
\hline $\begin{array}{l}\text { Grand Canyon University } \\
(2001-2003)\end{array}$ & 1.0 Straight Literature & $69-74^{c}$ \\
\hline $\begin{array}{l}\text { Greenville College } \\
(2000-2002)\end{array}$ & 1.5 Primarily Literature & 73 \\
\hline Hope International University & $\begin{array}{l}\text { Offered only through } \\
\text { California State U.at } \\
\text { Fresno }\end{array}$ & -- \\
\hline $\begin{array}{l}\text { Houghton College } \\
(2001-2002)\end{array}$ & 1.0 Straight Literature & 96 \\
\hline Houston Baptist University & 1.0 Straight Literature & 91 \\
\hline
\end{tabular}




\begin{tabular}{|c|c|c|}
\hline$(2000-2002)$ & & \\
\hline $\begin{array}{l}\text { Howard Payne University } \\
(2001-2002)\end{array}$ & 1.0 Straight Literature & 83 \\
\hline $\begin{array}{l}\text { Huntington College } \\
(2002-2004)\end{array}$ & 1.5 Primarily Literature & 73 \\
\hline $\begin{array}{l}\text { Indiana Wesleyan University } \\
(2001-2002)\end{array}$ & 1.0 Straight Literature & 88 \\
\hline $\begin{array}{l}\text { John Brown University } \\
(2001-2003)\end{array}$ & 1.5 Primarily Literature & 74 \\
\hline $\begin{array}{l}\text { Judson College (AL) } \\
(2002-2003)^{\mathrm{b}}\end{array}$ & 1.5 Primarily Literature & 66 \\
\hline $\begin{array}{l}\text { Judson College (IL) } \\
(2000-2002)\end{array}$ & 1.5 Primarily Literature & 74 \\
\hline $\begin{array}{l}\text { Kentucky Christian College } \\
(2001-2002)\end{array}$ & None offered & - \\
\hline $\begin{array}{l}\text { King College } \\
(2000-2002)\end{array}$ & 2.0 More Flexible & 40 \\
\hline $\begin{array}{l}\text { Lee University } \\
(2001-2002)\end{array}$ & 1.0 Straight Literature & 80 \\
\hline $\begin{array}{l}\text { LeToumeau University } \\
(2001-2002)\end{array}$ & 1.0 Straight Literature & 90 \\
\hline $\begin{array}{l}\text { Lipscomb University } \\
(2001-2002)^{\mathrm{b}}\end{array}$ & 1.0 Straight Literature & 85 \\
\hline $\begin{array}{l}\text { Malone College } \\
(2001-2002)\end{array}$ & 1.5 Primarily Literature & 71 \\
\hline $\begin{array}{l}\text { Messiah College } \\
(2001-2002)^{\mathrm{b}}\end{array}$ & 1.5 Primarily Literature & 71 \\
\hline $\begin{array}{l}\text { MidAmerica Nazarene U. } \\
.(2001-2002)\end{array}$ & 1.5 Primarily Literature & 70 \\
\hline $\begin{array}{l}\text { Milligan College } \\
(2001-2002)\end{array}$ & 1.0 Straight Literature & 91 \\
\hline $\begin{array}{l}\text { Montreat College } \\
(2001-2002)\end{array}$ & 1.5 Primarily Literature & 72 \\
\hline $\begin{array}{l}\text { Mount Vernon Nazarene C. } \\
(2001-2002)\end{array}$ & 1.0 Straight Literature & 91 \\
\hline $\begin{array}{l}\text { North Greenville College } \\
(2001-2003)\end{array}$ & 1.5 Primarily Literature & 83 \\
\hline $\begin{array}{l}\text { North Park University } \\
(2001-2003)^{+}\end{array}$ & 1.5 Primarily Literature & 66 \\
\hline $\begin{array}{l}\text { Northwest Christian College } \\
(2001-2002)\end{array}$ & $\begin{array}{l}\text { Offered through U. of } \\
\text { Oregon only }\end{array}$ & - \\
\hline $\begin{array}{l}\text { Northwest College (WA) } \\
(2001-2002)\end{array}$ & 2.0 More Flexible & 39 \\
\hline Northwest Nazarene U. & 1.0 Straight Literature & 76 \\
\hline
\end{tabular}




\begin{tabular}{|c|c|c|}
\hline$(2001-2002)$ & & \\
\hline $\begin{array}{l}\text { Northwestern College (IA) } \\
(2001-2003)\end{array}$ & 1.0 Straight Literature & 81 \\
\hline $\begin{array}{l}\text { Northwestern College (MN) } \\
(2001-2002)\end{array}$ & 2.0 More Flexible & 56 \\
\hline $\begin{array}{l}\text { Nyack College } \\
(2001-2002)\end{array}$ & 2.0 More Flexible & 68 \\
\hline $\begin{array}{l}\text { Oklahoma Baptist University } \\
(2002-2004)\end{array}$ & 1.5 Primarily Literature & 74 \\
\hline $\begin{array}{l}\text { Oklahoma Christian U. } \\
\text { (2001-2002) }\end{array}$ & $\begin{array}{l}1.5 \text { Primarily Literature } \\
\& \\
2.0 \text { More Flexible }^{* *} \\
\end{array}$ & $43-74^{c}$ \\
\hline $\begin{array}{l}\text { Oklahoma Wesleyan U. } \\
(2002-2004)\end{array}$ & 2.0 More Flexible & 63 \\
\hline $\begin{array}{l}\text { Olivet Nazarene University } \\
(2000-2002)\end{array}$ & 2.0 More Flexible & 60 \\
\hline $\begin{array}{l}\text { Oral Roberts University } \\
\left(200 \_-200\right)^{+}\end{array}$ & 1.0 Straight Literature & 81 \\
\hline $\begin{array}{l}\text { Palm Beach Atlantic College } \\
(2001-2002)\end{array}$ & 1.0 Straight Literature & 93 \\
\hline $\begin{array}{l}\text { Point Loma Nazarene U. } \\
(2001-2002)\end{array}$ & 1.0 Straight Literature & 81 \\
\hline $\begin{array}{l}\text { Redeemer University College } \\
(2000-2002)\end{array}$ & 1.0 Straight Literature & 81 \\
\hline $\begin{array}{l}\text { Roberts Wesleyan College } \\
(2000-2002)\end{array}$ & 1.0 Straight Literature & 75 \\
\hline $\begin{array}{l}\text { Seattle Pacific University } \\
(2000-2002)\end{array}$ & 2.0 More Flexible & 63 \\
\hline $\begin{array}{l}\text { Simpson College } \\
(2001-2002)\end{array}$ & 2.0 More Flexible & 39 \\
\hline $\begin{array}{l}\text { Southern Nazarene University } \\
(2001-2003)\end{array}$ & 2.0 More Flexible & 56 \\
\hline $\begin{array}{l}\text { Southern Wesleyan University } \\
(2001-2002)\end{array}$ & 1.5 Primarily Literature & $45-72^{c}$ \\
\hline $\begin{array}{l}\text { Southwest Baptist University } \\
(2001-2002)\end{array}$ & 1.5 Primarily Literature & 66 \\
\hline $\begin{array}{l}\text { Spring Arbor College } \\
(2001-2002)\end{array}$ & 1.5 Primarily Literature & 70 \\
\hline $\begin{array}{l}\text { Sterling College } \\
(2001-2002)^{+}\end{array}$ & 1.0 Straight Literature & 75 \\
\hline $\begin{array}{l}\text { Tabor College } \\
(2001-2002)\end{array}$ & 1.5 Primarily Literature & 64 \\
\hline Taylor U. & & \\
\hline
\end{tabular}




\begin{tabular}{|l|l|c|}
\hline The King's University C. & 1.0 Straight Literature & 75 \\
\hline $\begin{array}{l}\text { The Master's College } \\
(2000-2002)\end{array}$ & 1.0 Straight Literature & 88 \\
\hline $\begin{array}{l}\text { Trevecca Nazarene University } \\
(2001-2002)\end{array}$ & 1.0 Straight Literature & 77 \\
\hline $\begin{array}{l}\text { Trinity Christian College } \\
(2001-2002)\end{array}$ & 1.0 Straight Literature & 66 \\
\hline $\begin{array}{l}\text { Trinity International } \\
\text { University } \\
(2001-2002)^{c}\end{array}$ & 1.5 Primarily Literature & 88 \\
\hline $\begin{array}{l}\text { Trinity Western University } \\
(2002-2003)\end{array}$ & 1.0 Straight Literature & $69-86^{\mathrm{c}}$ \\
\hline $\begin{array}{l}\text { Union University } \\
(2001-2002)\end{array}$ & 1.5 Primarily Literature \\
\hline $\begin{array}{l}\text { University of Sioux Falls } \\
(2002-2003)\end{array}$ & 1.0 Straight Literature & 77 \\
\hline $\begin{array}{l}\text { Vanguard University (So. Cal. } \\
\text { C.) } \\
(2001-2002)\end{array}$ & 1.0 Straight Literature & 83 \\
\hline $\begin{array}{l}\text { Warner Pacific College } \\
(2001-2002)\end{array}$ & 1.0 Straight Literature & 86 \\
\hline $\begin{array}{l}\text { Warner Southern College } \\
(2000-2002)\end{array}$ & 1.5 Primarily Literature & 64 \\
\hline $\begin{array}{l}\text { Western Baptist College } \\
(2000-2001)\end{array}$ & 1.5 Primarily Literature & $78-85^{\mathrm{c}}$ \\
\hline $\begin{array}{l}\text { Westmont College } \\
(2002-2003)^{+}\end{array}$ & 1.0 Straight Literature & 92 \\
\hline $\begin{array}{l}\text { Wheaton College (IL) } \\
(2001-2002)\end{array}$ & 1.0 Straight Literature \\
\hline $\begin{array}{l}\text { Whitworth College } \\
(2001-2003)\end{array}$ & 2.0 More Flexible & 100 \\
\hline $\begin{array}{l}\text { William Tyndale College } \\
(200-200)\end{array}$ & 1.0 Straight Literature \\
\hline $\begin{array}{l}\text { Williams Baptist College } \\
(2001-2003)\end{array}$ & 1.0 Straight Literature & 61 \\
\hline arceng were rouned & 84 \\
\hline
\end{tabular}

${ }^{\mathrm{a}}$ Percentages were rounded off to the nearest whole number.

${ }^{b}$ Catalog information secured from institutional web site.

${ }^{c}$ Variations in the curriculum package account for range. 
EVIDENCE OF CHRISTIAN THOUGHT AMONG SELECTED CCCU ENGLISH CURRICULA

\begin{tabular}{|c|c|c|}
\hline $\begin{array}{l}\text { CCCU } \\
\text { Member } \\
\text { (Catalog or } \\
\text { Bulletin Dates) }\end{array}$ & \begin{tabular}{|l|} 
Introductory \\
Statements: \\
Reference to \\
Christian Thought \\
and/or Influence \\
$I S=$ Introductory \\
$\quad$ Statement \\
$M S=$ Mission \\
$\quad$ Statement \\
$G L=$ Goal \\
$O B=$ Objective \\
$I O=$ Other \\
\end{tabular} & $\begin{array}{l}\text { Course Descriptions: Reference to } \\
\text { Christian Thought and/or Influence } \\
\text { Instructional Level / Title (Hours) }\end{array}$ \\
\hline $\begin{array}{l}\text { Bethel College } \\
\text { (Minnesota) } \\
\text { 2001-2001 }\end{array}$ & $\begin{array}{l}\text { IS: } \\
\text { "The Department of } \\
\text { English approaches } \\
\text { the study of } \\
\text { literature and the } \\
\text { craft of writing from } \\
\text { a Christian } \\
\text { perspective that } \\
\text { recognizes faith as } \\
\text { integral to all } \\
\text { learning. We value } \\
\text { language as created } \\
\text { by God.... }\end{array}$ & 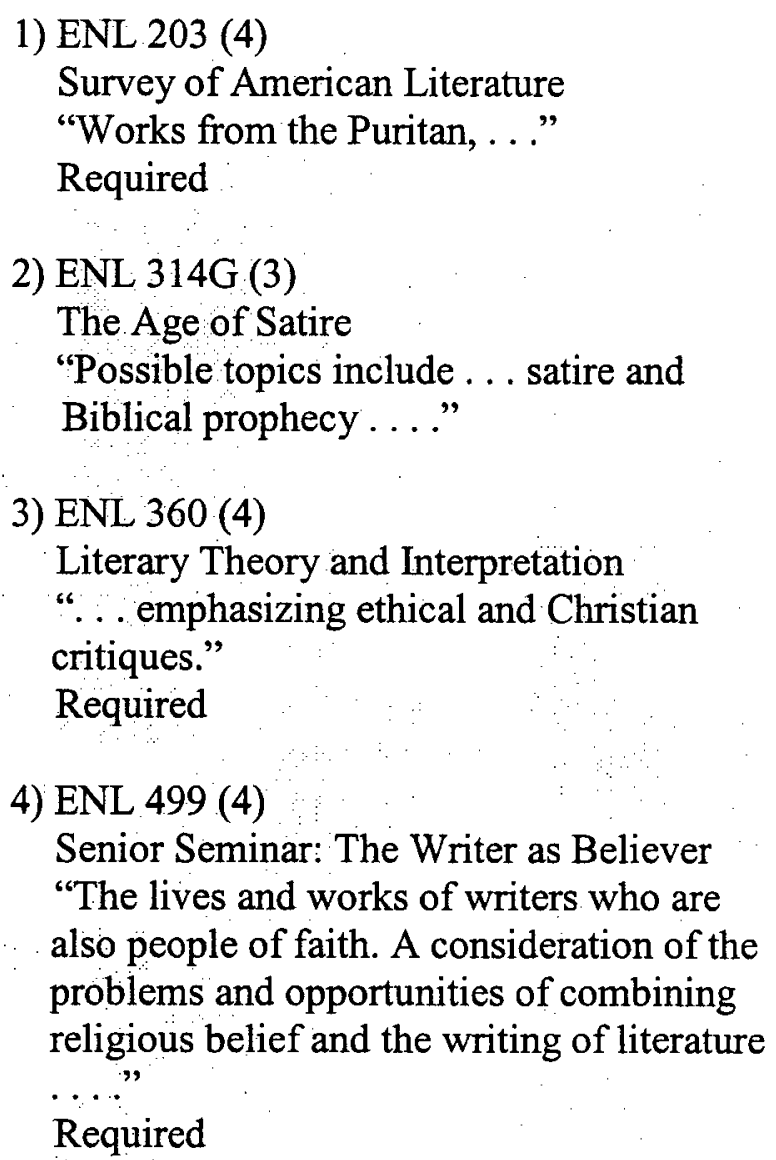 \\
\hline
\end{tabular}




\begin{tabular}{|c|c|c|}
\hline $\begin{array}{l}\text { CCCU } \\
\text { Member } \\
\text { (Catalog or } \\
\text { Bulletin Dates) }\end{array}$ & $\begin{array}{l}\text { Introductory } \\
\text { Statements: } \\
\text { Reference to } \\
\text { Christian Thought } \\
\text { and/or Influence } \\
I S=\text { Introductory } \\
\quad \text { Statement } \\
M S=\text { Mission } \\
\quad \text { Statement } \\
G L=\text { Goal } \\
O B=\text { Objective } \\
I O=\text { Other }\end{array}$ & $\begin{array}{l}\text { Course Descriptions: Reference to } \\
\text { Christian Thought and/or Influence } \\
\text { Instructional Level / Title (Hours) }\end{array}$ \\
\hline $\begin{array}{l}\text { Colorado } \\
\text { Christian U. } \\
\text { 2001-2002 }\end{array}$ & No reference made & $\begin{array}{l}\text { 1) ENGLISH } 380(3) \\
\text { Christian Writers } \\
\text { "Foundational literary works: their } \\
\text { scriptural...influences, and their } \\
\text { relationship to...modern Christian } \\
\text { writers." } \\
\text { Required }\end{array}$ \\
\hline $\begin{array}{l}\text { Dallas Baptist } \\
\text { U. } \\
2002-2004\end{array}$ & $\begin{array}{l}\text { MS: } \\
\text { “...the English } \\
\text { faculty strives 'to } \\
\text { produce servant } \\
\text { leaders' who can } \\
\text { 'integrate faith and } \\
\text { learning through } \\
\text { their respective } \\
\text { callings.... [Students] } \\
\text { are encouraged to } \\
\text { test their creative } \\
\text { insights against the } \\
\text { precepts of divine } \\
\text { truth as revealed in } \\
\text { the sacred texts of } \\
\text { the Bible." }\end{array}$ & $\begin{array}{l}\text { 1) ENGL } 4307 \text { (3) } \\
\text { Creative Christian Writing } \\
\text { "A seminar designed...to learn how to share } \\
\text { the message of Christ through the printed } \\
\text { word." } \\
\text { 2) ENGL } 4308 \text { (3) } \\
\text { Milton and Bunyan } \\
\text { "Major works of Milton and Bunyan will } \\
\text { be studied as examples of Puritan } \\
\text { literature." } \\
\text { 3) ENGL } 4314 \text { (3) } \\
\text { C. S. Lewis } \\
\text { "... acquaint students with a wide range of } \\
\text { C. S. Lewis' works... [and] explore the idea } \\
\text { of a shared literary fellowship as modeled } \\
\text { by the Inklings." }\end{array}$ \\
\hline
\end{tabular}




\begin{tabular}{|c|c|c|}
\hline $\begin{array}{l}\text { CCCU } \\
\text { Member } \\
\text { (Catalog or } \\
\text { Bulletin Dates) }\end{array}$ & 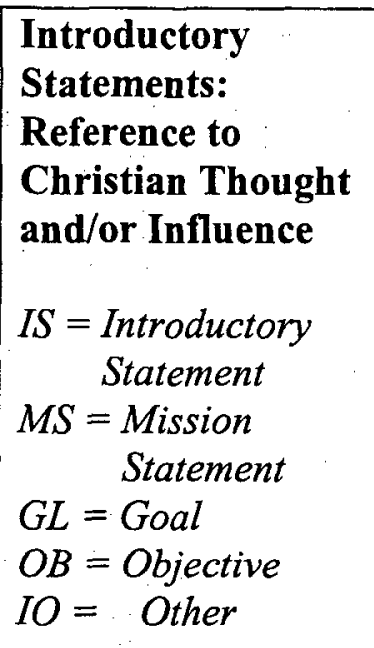 & $\begin{array}{l}\text { Course Descriptions: Reference to } \\
\text { Christian Thought and/or Influence } \\
\text { Instructional Level / Title (Hours) }\end{array}$ \\
\hline $\begin{array}{l}\text { Dordt C. } \\
\text { 2001-2002 }\end{array}$ & No reference made & $\begin{array}{l}\text { 1) ENGLISH 201 (3) } \\
\text { American Literature } \\
\text { "Selected prose and poetry of the Puritans and } \\
\text { Neo-Classicals, and an extensive study of the } \\
\text { American Romantics [including Hawthorne]." } \\
\text { Required } \\
\text { 2) ENGLISH 202 (3) } \\
\text { American Literature } \\
\text { "Students will be expected to respond to the } \\
\text { literature from their own Christian point of } \\
\text { view." } \\
\text { Required } \\
\text { 3) ENGLISH } 207 \text { (3) } \\
\text { World Literature } \\
\text { "Medieval works include...selections from } \\
\text {...Chaucer, and Dante's Inferno. Renaissance } \\
\text { works include...selections from Erasmus..." } \\
\text { 4) ENGLISH } 221 \text { (3) } \\
\text { The Short Story } \\
\text { "...students will study contemporary writers } \\
\text { such as ...Larry Woiwode...." } \\
\text { } \\
\text { 5) ENGLISH } 222 \text { (3) } \\
\text { Themes in Literature } \\
\text { "...and the search for religious certainty.; } \\
\text { faith affects the work of writing fiction." }\end{array}$ \\
\hline
\end{tabular}




\begin{tabular}{|c|c|c|}
\hline $\begin{array}{l}\text { CCCU } \\
\text { Member } \\
\text { (Catalog or } \\
\text { Bulletin Dates) }\end{array}$ & 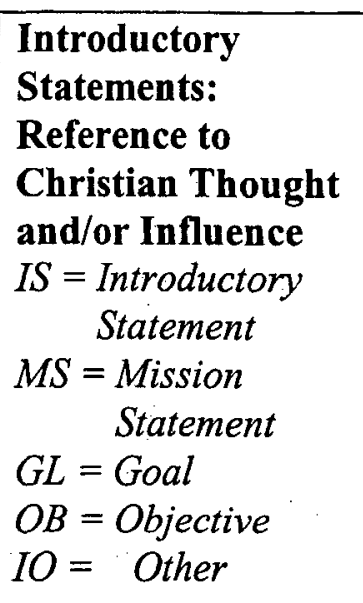 & $\begin{array}{l}\text { Course Descriptions: Reference to } \\
\text { Christian Thought and/or Influence } \\
\text { Instructional Level / Title (Hours) }\end{array}$ \\
\hline $\begin{array}{l}\text { Dordt C. } \\
\text { 2001-2002 }\end{array}$ & No reference made & $\begin{array}{l}\text { 6) ENGLISH } 304 \text { (3) } \\
\text { Fiction Writing } \\
\text { “...in workshop format and discussing } \\
\text { technique, as well as the ways in which } \\
\text { one's } \\
\text { faith affects the writing of fiction." } \\
\text { 7) ENGLISH } 314 \text { (3) } \\
\text { Earlier British Literature } \\
\text { "A survey...including Chaucer,..Spenser, } \\
\text {..Donne, Herbert,...and Bunyan. Special } \\
\text { attention will be paid to the Scriptural } \\
\text { tradition } \\
\text { which this literature evokes." } \\
\text { Required } \\
\text { 8) ENGLISH } 316 \text { (3) } \\
\text { Later British Literature } \\
\text { “...A survey [from } 1700 \text { to] Hopkins." } \\
\text { Required } \\
\text { 9) ENGLISH } 318 \text { (3) } \\
\text { Modern British Literature } \\
\text { “A study of the different ideas and } \\
\text { techniques...of 20th century British writers } \\
\text { such as Hardy,...Auden...." } \\
\text { Required }\end{array}$ \\
\hline
\end{tabular}




\begin{tabular}{|c|c|c|}
\hline $\begin{array}{l}\text { CCCU } \\
\text { Member } \\
\text { (Catalog or } \\
\text { Bulletin Dates) }\end{array}$ & 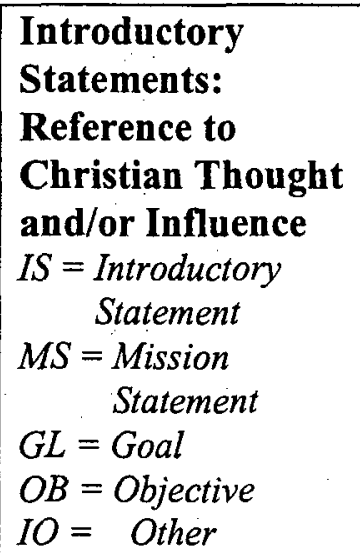 & $\begin{array}{l}\text { Course Descriptions: Reference to } \\
\text { Christian Thought and/or Influence } \\
\text { Instructional Level / Title (Hours) }\end{array}$ \\
\hline $\begin{array}{l}\text { Dordt C. } \\
2001-2002\end{array}$ & No reference made & $\begin{array}{l}\text { 10) ENGLISH 321 (3) } \\
\text { The American Novel } \\
\text { "Such authors as Hawthorne... will be } \\
\text { studied." } \\
\text { 11) ENGLISH } 322(3) \\
\text { The English Novel } \\
\text { "...with novelists such as Burney, the } \\
\text { Brontes..." } \\
\text { 12) ENGLISH } 323 \text { (3) } \\
\text { Modern and Contemporary English and } \\
\text { American Novels } \\
\text { "Novelists include...O'Conner (sic)." } \\
\text { 13) ENGLISH } 333 \text { (3) } \\
\text { History and Theory of Literary Criticism } \\
\text { "...with the aim of formulating clearer } \\
\text { Christian theories of literature." }\end{array}$ \\
\hline $\begin{array}{l}\text { Gordon C. } \\
2001-2002\end{array}$ & No reference made & $\begin{array}{l}\text { 1) EN } 330 \text { (4) } \\
\text { Milton and the Seventeenth Century } \\
\text { "... Culminates in reading Milton's } \\
\text { Paradise Lost, set in context of severe } \\
\text { religious, political and social crises that } \\
\text { divided England." } \\
\text { 2) EN } 332 \text { (4) } \\
\text { Classicism and Romanticism } \\
\text { "... Enlightenment reflected in works } \\
\text { of...Swift and Johnson." }\end{array}$ \\
\hline
\end{tabular}




\begin{tabular}{|c|c|c|}
\hline $\begin{array}{l}\text { CCCU } \\
\text { Member } \\
\text { (Catalog or } \\
\text { Bulletin Dates) }\end{array}$ & $\begin{array}{l}\text { Introductory } \\
\text { Statements: } \\
\text { Reference to } \\
\text { Christian Thought } \\
\text { and/or Influence } \\
I S=\text { Introductory } \\
\quad \text { Statement } \\
M S=\text { Mission } \\
\quad \text { Statement } \\
G L=\text { Goal } \\
O B=\text { Objective } \\
\text { IO }=\text { Other } \\
\end{array}$ & $\begin{array}{l}\text { Course Descriptions: Reference to } \\
\text { Christian Thought and/or Influence } \\
\text { Instructional Level / Title (Hours) }\end{array}$ \\
\hline $\begin{array}{l}\text { Gordon C. } \\
2001-2002\end{array}$ & No reference made & $\begin{array}{l}\text { 3) EN } 348 \text { (4) } \\
\text { Contemporary American Literature } \\
\text { "...concerned with Jewish, Christian, } \\
\text { feminist and minority issues." } \\
\text { 4) EN } 360 \text { (4) } \\
\text { Biblical Narrative } \\
\text { "Analyzes major themes and characters } \\
\text { from Old Testament and gospel } \\
\text { narratives." } \\
\text { 5) EN } 470(4) \\
\text { Chaucer and the Medieval Tradition } \\
\text { "Studies Canterbury Tales and other } \\
\text { works...... Set in artistic, theological and } \\
\text { philosophical contexts of Christian Middle } \\
\text { Ages in Europe." }\end{array}$ \\
\hline $\begin{array}{l}\text { Goshen C. } \\
2001-2003\end{array}$ & No reference made & $\begin{array}{l}\text { 1) Engl } 207 / 307 \text { (3) } \\
\text { Interdisciplinary Literature } \\
\ldots \text { Special topics include...Mennonite } \\
\text { Literature...by U. S. and Canadian writers, } \\
\text { studied in relation to Mennonite history, } \\
\text { culture and theology...." } \\
\text { 2) Engl } 230 \text { (3). } \\
\text { Literature and Film } \\
\text { "... Special attention to philosophical, } \\
\text { ethical, political, cultural, spiritual } \\
\text { and gender related issues...." }\end{array}$ \\
\hline
\end{tabular}




\begin{tabular}{|c|c|c|}
\hline $\begin{array}{l}\text { CCCU } \\
\text { Member } \\
\text { (Catalog or } \\
\text { Bulletin Dates) }\end{array}$ & $\begin{array}{l}\text { Introductory } \\
\text { Statements: } \\
\text { Reference to } \\
\text { Christian Thought } \\
\text { and/or Influence } \\
\text { IS = Introductory } \\
\quad \text { Statement } \\
M S=\text { Mission } \\
\quad \text { Statement } \\
G L=\text { Goal } \\
O B=\text { Objective } \\
I O=\quad \text { Other } \\
\end{array}$ & $\begin{array}{l}\text { Course Descriptions: Reference to } \\
\text { Christian Thought and/or Influence } \\
\text { Instructional Level / Title (Hours) }\end{array}$ \\
\hline $\begin{array}{l}\text { Houghton C. } \\
2001-2002\end{array}$ & $\begin{array}{l}\text { IO: } \\
\text { “...also appropriate } \\
\text { for pre-seminary... } \\
\text { students." } \\
\qquad \begin{array}{c}\ddots \\
\vdots\end{array}\end{array}$ & $\begin{array}{l}\text { 1) ENGL } 215 \text { (3) } \\
\text { American Literature I } \\
\text { "Emphasis on Puritan thought...." } \\
\text { Required } \\
\text { 2) ENGL } 311 \text { (3) } \\
\text { The English Renaissance } \\
\text { Poetry and prose from Sidney to } \\
\text { Milton.....Attention given to...religious } \\
\text { background. Emphasis on ...Milton, and } \\
\text { the } 17 \text { th century devotional poets. } \\
\text { 3) ENGL } 390 \text { (3) } \\
\text { Special Topics in Literature } \\
\text { "...e.g., the Oxford Christians..." }\end{array}$ \\
\hline $\begin{array}{l}\text { King C. (TN) } \\
2001-2002\end{array}$ & $\begin{array}{l}\text { IO: } \\
\text { "...English majors } \\
\text { are prepared to } \\
\text { pursue careers in } \\
\text {...ministry...." }\end{array}$ & $\begin{array}{l}\text { 1a) ENGL } 2170 \text { (3) } \\
\text { A Survey of Western Literature } \\
\text { "St. Augustine...depicted life as a spiritual } \\
\text { journey and beginning with this remarkable } \\
\text { spiritual autobiography.., students embark on } \\
\text { a journey in search of meaning [through] } \\
\text { classics of the western literary tradition." } \\
\text { 1b) ENGL } 2170 \text { (3) } \\
\text { Literature and the Quest for Significance: } \\
\text { A Survey of Western Literature } \\
\text { "A study of Augustinian themes in literature } \\
\text { from the classical through the modern period, } \\
\text { beginning with...The Confessions...." } \\
\text { Required }\end{array}$ \\
\hline
\end{tabular}




\begin{tabular}{|c|c|c|}
\hline $\begin{array}{l}\text { CCCU Member } \\
\text { (Catalog or } \\
\text { Bulletin Dates) }\end{array}$ & \begin{tabular}{|l|} 
Introductory \\
Statements: \\
Reference to \\
Christian Thought \\
and/or Influence \\
$I S=\quad$ Introductory \\
$\quad$ Statement \\
$M S=$ Mission \\
$\quad$ Statement \\
GL $=$ Goal \\
OB $=$ Objective \\
$I O=$ Other
\end{tabular} & $\begin{array}{l}\text { Course Descriptions: Reference to } \\
\text { Christian Thought and/or Influence } \\
\text { Instructional Level / Title (Hours) }\end{array}$ \\
\hline $\begin{array}{l}\text { King C. (TN) } \\
2001-2002\end{array}$ & $\begin{array}{l}\text { IO: } \\
\text { “...English majors } \\
\text { are prepared to } \\
\text { pursue careers in } \\
\text {...ministry...." }\end{array}$ & $\begin{array}{l}\text { 2a) ENG } 2200-2500(2) \\
\text { Literary Passages } \\
\text { "[Courses] might include Southern } \\
\text { Autobiography, William Faulkner, Puritan } \\
\text { writers,...The Oxford Christian Writers...." } \\
\text { 2b) ENG } 2200-2500 \text { (F/S) (2) } \\
\text { Literary Passages: Reading and Writing } \\
\text { about Literature } \\
\text { "Special topics....Courses include...The } \\
\text { Oxford Christian Writers,..Topics in } \\
\text { Southern Literature,...." } \\
\text { Required (4 hours limit) } \\
\text { 3) ENG } 3210 \text { (2) } \\
\text { Technical and Specialty Writing } \\
\text { "[How writing for] various fields such as } \\
\text {...religion....is prepared for a general } \\
\text { audience." } \\
\text { Optional } \\
\text { 4) ENG } 3440 \text { (2) } \\
\text { Chaucer } \\
\text { "A study of ...and selections from the } \\
\text { Canterbury Tales,...." } \\
\text { Optional }\end{array}$ \\
\hline
\end{tabular}




\begin{tabular}{|c|c|c|}
\hline $\begin{array}{l}\text { CCCU } \\
\text { Member } \\
\text { (Catalog or } \\
\text { Bulletin Dates) }\end{array}$ & \begin{tabular}{|l|} 
Introductory \\
Statements: \\
Reference to \\
Christian Thought \\
and/or Influence \\
IS $=$ Introductory \\
$\quad$ Statement \\
$M S=$ Mission \\
$\quad$ Statement \\
GL $=$ Goal \\
OB $=$ Objective \\
$I O=$ Other \\
\end{tabular} & $\begin{array}{l}\text { Course Descriptions: Reference to } \\
\text { Christian Thought and/or Influence } \\
\text { Instructional Level / Title (Hours) }\end{array}$ \\
\hline $\begin{array}{l}\text { King C. (TN) } \\
2001-2002\end{array}$ & $\begin{array}{l}\text { IO: } \\
\text { "...English majors are } \\
\text { prepared to pursue } \\
\text { careers in } \\
\text {...ministry...." }\end{array}$ & $\begin{array}{l}\text { 5) ENG } 3480 \text { (2) } \\
\text { Milton } \\
\text { "A study of Paradise Lost, Paradise } \\
\text { Regained, and selected prose and poetry...." } \\
\text { Optional } \\
\text { 6) ENG } 3540 \text { (4) } \\
\text { British Romanticism and the Nineteenth... } \\
\text { Century } \\
\text { "The course includes writers such as... } \\
\text { Hopkins..." } \\
\text { Optional }\end{array}$ \\
\hline $\begin{array}{l}\text { Lee U. } \\
\text { 2001-2002 }\end{array}$ & $\begin{array}{l}\text { IO: } \\
\text { "The capstone course, } \\
\text { English in Christian } \\
\text { Perspective, assists } \\
\text { students in integrating } \\
\text { their Christian faith } \\
\text { with scholarship in } \\
\text { the discipline." }\end{array}$ & $\begin{array}{l}\text { 1) ENG } 322 \text { (3) } \\
\text { World Literature } \\
\text { "...with emphasis on...Middle Ages..." } \\
\text { Required } \\
\text { 2) ENG } 325 \text { (3) } \\
\text { Literature of the Bible } \\
\text { 3) ENG } 415 \text { (3) } \\
\text { Milton } \\
\text { “...with major emphasis on Paradise Lost, } \\
\text { and a brief survey of his prose." } \\
\text { 4) ENG } 421 \text { (3) } \\
\text { Restoration and Eighteenth Century } \\
\text { Literature } \\
\text { “...with special emphasis on...Pope, Swift, } \\
\text { and Johnson." }\end{array}$ \\
\hline
\end{tabular}




\begin{tabular}{|c|c|c|}
\hline $\begin{array}{l}\text { CCCU } \\
\text { Member } \\
\text { (Catalog or } \\
\text { Bulletin Dates) }\end{array}$ & \begin{tabular}{|l} 
Introductory \\
Statements: \\
Reference to \\
Christian Thought \\
and/or Influence \\
IS $=$ Introductory \\
$\quad$ Statement \\
$M S=$ Mission \\
$\quad$ Statement \\
GL $=$ Goal \\
OB $=$ Objective \\
$I O=$ Other
\end{tabular} & $\begin{array}{l}\text { Course Descriptions: Reference to } \\
\text { Christian Thought and/or Influence } \\
\text { Instructional Level / Title (Hours) }\end{array}$ \\
\hline $\begin{array}{l}\text { Lee U. } \\
\text { 2001-2002 }\end{array}$ & & $\begin{array}{l}\text { 5) ENG } 431 \text { (3) } \\
\text { English Romantic Period } \\
\text { “...with special emphasis on the poetry of } \\
\text { Blake,...Coleridge,..." } \\
\text { 6) ENG } 441 \text { (3) } \\
\text { Victorian Literature } \\
\text { "The poetry of ...Browning...will be } \\
\text { emphasized." } \\
\text { 7) ENG } 352 \text { (3) } \\
\text { Women Writers } \\
\text { "...by women of the Middle Ages,..." }\end{array}$ \\
\hline $\begin{array}{l}\text { Malone C. } \\
(2001-2002)\end{array}$ & $\begin{array}{l}\text { IO: } \\
\text { "Surrounded by a } \\
\text { Christian atmosphere, } \\
\text { a major (sic) in } \\
\text { English...equips } \\
\text { students..." }\end{array}$ & $\begin{array}{l}\text { 1) ENG } 322(3) \\
\text { World Literature } \\
\text { "A close reading of texts from diverse } \\
\text { historical, cultural, and religious contexts." } \\
\text { (Note: Course descriptions contain few authors } \\
\text { by name.) }\end{array}$ \\
\hline $\begin{array}{l}\text { Northwest } \\
\text { Nazarene U. } \\
\text { (2001-2002) }\end{array}$ & No reference made & $\begin{array}{l}\text { 1) EN } 353 \text { The Bible as Literature (3) } \\
\text { "A study of the literary qualities of the } \\
\text { English Bible." } \\
\text { 2) EN } 432 \text { Chaucer and His Age (3) } \\
\text { 3) EN } 433 \text { Milton and His Age (3) } \\
\text { Note: EN } 432 \text { or } 433 \text { is required. }\end{array}$ \\
\hline
\end{tabular}




\begin{tabular}{|c|c|c|}
\hline $\begin{array}{l}\text { CCCU } \\
\text { Member } \\
\text { (Catalog or } \\
\text { Bulletin Dates) }\end{array}$ & $\begin{array}{l}\text { Introductory } \\
\text { Statements: } \\
\text { Reference to } \\
\text { Christian Thought } \\
\text { and/or Influence } \\
I S=\text { Introductory } \\
\quad \text { Statement } \\
M S=\text { Mission } \\
\quad \text { Statement } \\
G L=\text { Goal } \\
O B=\text { Objective } \\
I O=\text { Other }\end{array}$ & $\begin{array}{l}\text { Course Descriptions: Reference to } \\
\text { Christian Thought and/or Influence } \\
\text { Instructional Level / Title (Hours) }\end{array}$ \\
\hline $\begin{array}{l}\text { Redeemer U. C. } \\
(2000-2002)\end{array}$ & No reference made & $\begin{array}{l}\text { 1) ENGLISH } 341 \text { (NA) } \\
\text { Medieval English Literature } \\
\text { “...with special attention to...Chaucer." } \\
\text { 2) ENGLISH } 343 \text { (NA) } \\
\text { Seventeenth-Century English Literature } \\
\text { "...with special attention to the works of } \\
\text { Donne, Herbert, and Milton.” } \\
\text { 3) ENGLISH } 344 \text { (NA) } \\
\text { Eighteenth-Century English Literature } \\
\text { “...works by...Pope, Swift, Defoe,...and } \\
\text { Johnson.." } \\
\text { 4) ENGLISH } 345 \text { (NA) } \\
\text { Nineteenth-Century English Literature I. } \\
\text { Romantic “...including works by Blake } \\
\text {...Coleridge..." } \\
\text { 5) ENGLISH } 346 \text { (NA) } \\
\text { Nineteenth-Century English Literature II: } \\
\text { “...including [G. M. Hopkins...and T. S. } \\
\text { Eliot:]" } \\
\text { 6) ENGLISH } 347 \text { (NA) } \\
\text { Twentieth-Century English Literature } \\
\text { “...works by ...Y Yeats, Eliot,...and Auden." }\end{array}$ \\
\hline
\end{tabular}




\begin{tabular}{|c|c|c|}
\hline $\begin{array}{l}\text { CCCU } \\
\text { Member } \\
\text { (Catalog or } \\
\text { Bulletin Dates) }\end{array}$ & $\begin{array}{l}\text { Introductory } \\
\text { Statements: } \\
\text { Reference to } \\
\text { Christian Thought } \\
\text { and/or Influence } \\
\text { IS = Introductory } \\
\text { Statement } \\
M S=\text { Mission } \\
\quad \text { Statement } \\
G L=\text { Goal } \\
O B=\text { Objective } \\
I O=\text { Other } \\
\end{array}$ & $\begin{array}{l}\text { Course Descriptions: Reference to } \\
\text { Christian Thought and/or Influence } \\
\text { Instructional Level / Title (Hours) }\end{array}$ \\
\hline $\begin{array}{l}\text { Seattle Pacific } \\
\text { U. } \\
(2001-2002)\end{array}$ & $\begin{array}{l}\text { IO: } \\
\text { "...to explore and } \\
\text { shape our views of } \\
\text { God." } \\
\text { "...to enter such } \\
\text { professions as the } \\
\text { ministry." } \\
\text { "...to enter life } \\
\text { [appreciating] God's } \\
\text { gifts of language and } \\
\text { liteature." } \\
\text { OB: } \\
\text { "Understand the } \\
\text { relationship between } \\
\text { literature and the } \\
\text { Christian faith,.." } \\
\text { IO: } \\
\text { "...Image: } A \text { Journal } \\
\text { of Arts and Religion" } \\
\text { (SPU publication) }\end{array}$ & 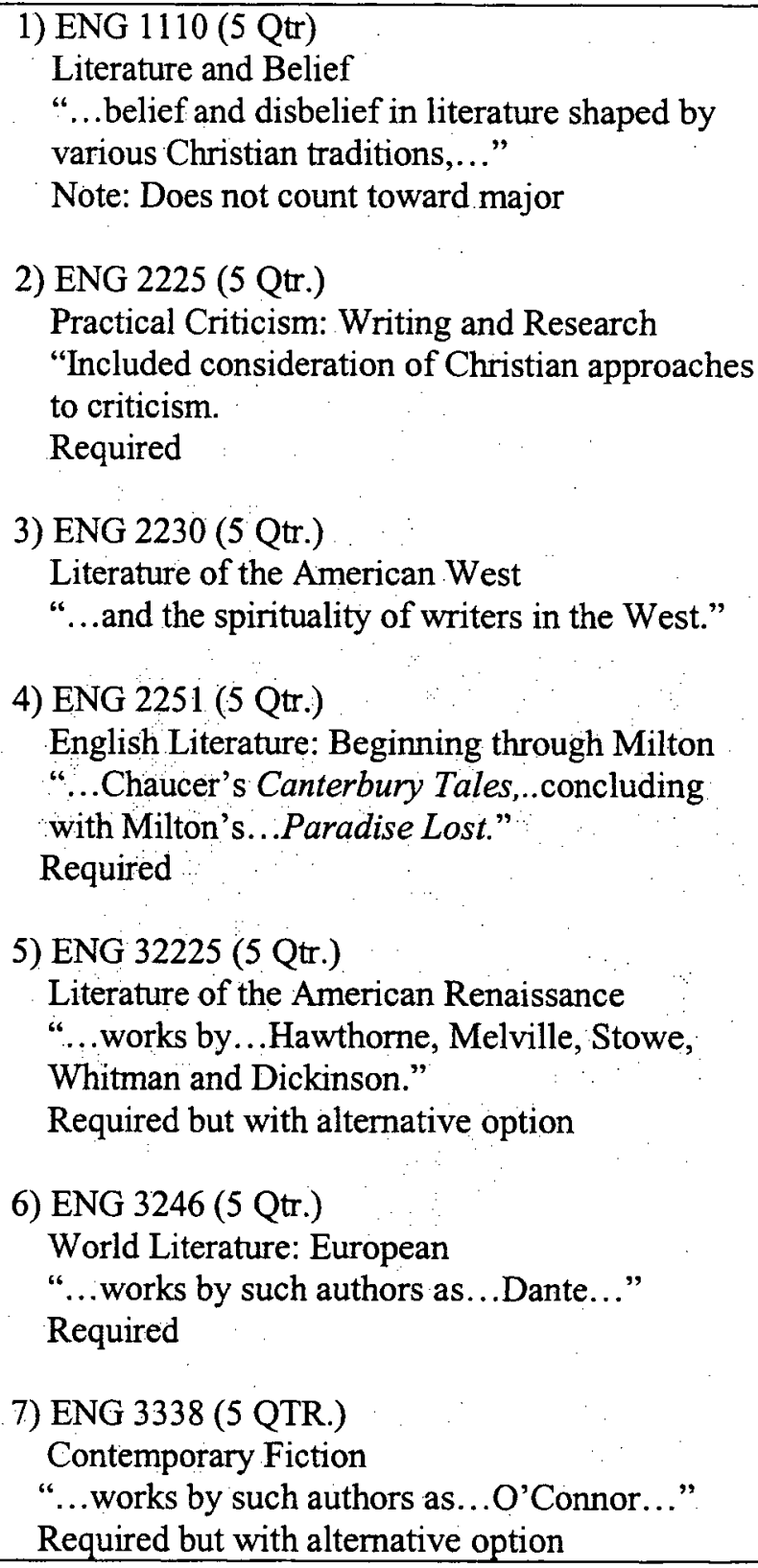 \\
\hline
\end{tabular}




\begin{tabular}{|c|c|c|}
\hline $\begin{array}{l}\text { CCCU } \\
\text { Member } \\
\text { (Catalog or } \\
\text { Bulletin Dates) }\end{array}$ & 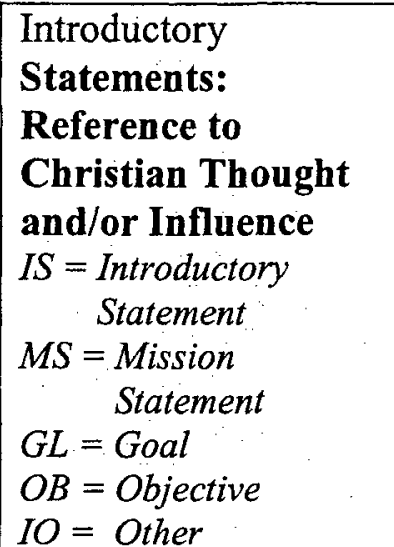 & $\begin{array}{l}\text { Course Descriptions: Reference to } \\
\text { Christian Thought and/or Influence } \\
\text { Instructional Level / Title (Hours) }\end{array}$ \\
\hline $\begin{array}{l}\text { Seattle Pacific U. } \\
2001-2002\end{array}$ & & $\begin{array}{l}\text { 8) ENG } 4225 \text { (5 Qtr.) } \\
\text { Senior Capstone Seminar } \\
\text { "Examples...include Canterbury Tales, } \\
\text { Paradise Lost,..." } \\
\text { Required } \\
\text { 9) ENG } 4661 \text { ( } 3 \text { Qtr.) } \\
\text { The Best of C. S. Lewis } \\
\text { "Identifies basic literary, philosophical and } \\
\text { theological cateories of Lewis' works." } \\
\text { 10) ENG } 4921 \text { (1=5 Qtr.) } \\
\text { Directed Readings in the C. S. Lewis } \\
\text { Circle "...in the fiction and/or literary } \\
\text { criticism of C. S. Lewis, J. R. R. Tolkien, } \\
\text { D. L. Sayers, and Charles Williams." }\end{array}$ \\
\hline $\begin{array}{l}\text { Westmont C. } \\
2002-2003\end{array}$ & $\begin{array}{l}\text { I. O. } \\
\text { "Graduating majors } \\
\text { have entered... } \\
\text { pastoral and parachurch } \\
\text { ministries..." } \\
\text { GL.. } \\
\text { "...develop an } \\
\text { understanding and } \\
\text { appreciation of the } \\
\text { principal areas of } \\
\text { human knowledge, } \\
\text { including Christianity." }\end{array}$ & $\begin{array}{l}\text { 1) ENG } 121 \text { (Junior Level Course) (4) } \\
\text { Romantic Literature } 179801832 \\
\text { “...from Blake to Keats.” } \\
\text { Required but with alternative option } \\
\text { 2) ENG } 130 \text { (Junior Level Course) (4) } \\
\text { Major American Writers to } 1865 \\
\text { “... [writings of] Hawthorne..., Emerson } \\
\text { and Thoreau..." } \\
\text { Required but with alternative option } \\
\text { 3) ENG 132 (Junior Level Course) (4) } \\
\text { Major American Writers, 1914-1945 } \\
\text { “...poetry of Frost and Eliot..." } \\
\text { Required but with alternative option }\end{array}$ \\
\hline
\end{tabular}




\begin{tabular}{|c|c|c|}
\hline $\begin{array}{l}\text { CCCU } \\
\text { Member } \\
\text { (Catalog or } \\
\text { Bulletin Dates) }\end{array}$ & $\begin{array}{l}\text { Introductory } \\
\text { Statements: } \\
\text { Reference to } \\
\text { Christian Thought } \\
\text { and/or Influence } \\
\text { IS = Introductory } \\
\quad \text { Statement } \\
M S=\text { Mission } \\
\quad \text { Statement } \\
G L=\text { Goal } \\
O B=\text { Objective } \\
I O=\text { Other } \\
\end{array}$ & $\begin{array}{l}\text { Course Descriptions: Reference to } \\
\text { Christian Thought and/or Influence } \\
\text { Instructional Level / Title (Hours) }\end{array}$ \\
\hline $\begin{array}{l}\text { Westmont C. } \\
(2002-2003 \text {, } \\
\text { off web site })\end{array}$ & $\begin{array}{l}\text { I. O. } \\
\text { "Graduating majors } \\
\text { have entered... } \\
\text { pastoral and parachurch } \\
\text { ministries..." } \\
\text { GL: } \\
\text { "...develop an } \\
\text { understanding and } \\
\text { appreciation of the } \\
\text { principal areas of } \\
\text { human knowledge, } \\
\text { including Christianity." } \\
\text { "...be equipped to } \\
\text { accept social, } \\
\text { religious...positions of } \\
\text { trust and leadership." }\end{array}$ & $\begin{array}{l}\text { 4) ENG } 151 \text { (Junior Level Course) (4) } \\
\text { Milton and the Early Seventeenth Century } \\
\text { "...to Milton." } \\
\text { Required but with alternative } \\
\text { 5) ENG } 152 \text { (Junior Level Course) (4) } \\
\text { Chaucer and Medieval Literature } \\
\text { Required but with alternative option } \\
\text { 6) ENG } 169 \text { (Junior Level Course) (4) } \\
\text { Women Writers } \\
\text { “...questions related to...spirituality." } \\
\text { Required but with alternative option } \\
\text { 7) ENG } 165 \text { (Junior Level Course) (4) } \\
\text { Topics in World Literature } \\
\text { “...such as...Dante..." } \\
\text { Required but with alternative option } \\
\text { 8) ENG } 166 \text { (Junior Level Course) (4) } \\
\text { Neoclassic Literature, 1660-1798 } \\
\text { "...by writers such as Bunyan,..Pope, } \\
\text { Swift, Johnson...” } \\
\text { Required but with alternative option } \\
\text { 9) ENG } 181 \text { (Junior Level Course) (4) } \\
\text { Twentieth-Century Poetry } \\
\text { “...by such poets as Hopkins, Yeats, } \\
\text { Eliot...” } \\
\text { Required but with alternative option } \\
\text { 10) ENG } 185 \text { (Junior Level Course) (4) } \\
\text { Twentieth-Century Irish Literature } \\
\text { “...by writers from Yeats, Joyce, Synge } \\
\ldots \text {... }\end{array}$ \\
\hline
\end{tabular}




\section{APPENDIX E}

\section{JOURNALS}

\section{Dallas Baptist University (TX) Analysis}

Dallas Baptist University, with its main campus located near Dallas, Texas, reported a record enrollment of 4302 for 2001 (Dallas Baptist University Undergraduate Catalog, 2002-2004, p. 8). In an introductory statement to its English curriculum, the 2002-2004 catalog aligned itself with the university mission statement in "[striving]" "to produce servant leaders' who can 'integrate, faith and learning through their respective callings"' (p. 202). Further, this opening statement declared that Dallas Baptist University students-both [English] majors and non-majors-[were] encouraged to test their creative insights against the precepts of divine truth as revealed in the sacred texts of the Bible. (p. 202)

By these declarations, the English curriculum posited a theistic orientation consistent with the university's Baptist heritage.

While that introductory statement reaffirmed the university mission, it did not express a specific mission statement for the English curriculum. Instead, the opening stated that, "The English program of the University is designed to assist in that goal" (specifically, "“to produce servant leaders' who can 'integrate faith and learning..."'). This introductory lacked a specific mission for the English curriculum, a mission concomitant to the university mission statement but singularly pertinent to this departmental curriculum. Such a mission statement would include a focused purpose defining the role(s) of the English curriculum. 
Instead, this introduction of English studies offered an apparent departmental mission statement, identifying broad purposes: "Through courses in writing instruction, the English faculty endeavor to stress insightful reading, critical thinking, and proficient oral and written communication" (p. 202). The opening then claimed "through careful instruction in literature," Dallas Baptist students "[were] encouraged to test their creative insights against the precepts of divine truth" (p. 202). This claim, like its attendant claims regarding "insightful reading, critical thinking, and proficient ... communication" skills, sounded sufficiently generic to have introduced more than one departmental mission; it would have suited, for instance, the "General Studies Major" or perhaps even the "Biblical Studies Major." These statements were simply too inclusive to introduce the English department, much less the curriculum, to the student reader.

Such broad, service-oriented claims preceded the four-part "Goal of the English Major," whose first point declared that "The department will provide English majors and minors, as well as students in foundation courses, with a curriculum which equips them to think, read, and write critically" (p. 202).

Saying nothing about the nature of English as a discipline, this initial point established the English department and curriculum as service-oriented entities. Although faculty readers undoubtedly understood that important (but often controversial) role for English studies (and may have questioned its impact on the major), student readers would hardly have thought of English in terms of "service" to the university. Would they have been interested? Certainly, this first item under the bold headline "Goal of the English Major" did not inform students about the English major itself. 
Perhaps the second aspect of the "Goal of the English major" appealed more to student readers with its mention of "job searches and/or graduate school matriculation" ( $\mathrm{p}$ 202). This item proved more student oriented as it promised departmental "advice and direction for English majors and minors" regarding their future plans. This point, however, offered no specific details about the relationship between the English curriculum and future work or graduate studies. No suggestion appeared that English students enter diverse career fields such as education or publication, nor that they enter graduate studies in law, theology, or library science. This second point, like the first under "Goal of the English Major," declared what the English department provided but offered no information about the English major itself.

Nor did the third point. It, too, focused on departmental responsibility: "The department will support University-wide writing goals" (p. 202). This significant item emphasized writing goals, including "among literature writing courses," but it did not explain to student readers (a) what "literature writing courses" were, (b) why they were important enough to be stressed by the entire university and supported by the English department, nor (c) what "the Writing Across the Curriculum program" constituted (p. 202). Student readers of this curriculum would have had to infer how this point pertained to the English major, for no specific explanation or detail showed how it applied to students following this curriculum.

If the first three aspects of the "Goal of the English Major" proved remote for student readers, the fourth virtually ignored them for it addressed "full-time and part-time faculty" (p. 202). Concluding with its anaphoric expression, "The department will..," this point promised to "cultivate and support professional, scholarly, and service opportunities 
for ... faculty in order to encourage excellence in teaching" (p. 202). While this intention (especially if realized) proved significant and laudable, and while students undoubtedly would have appreciated that call to "excellence," the point did not directly pertain to the English curriculum. Like its preceding points, it directly concerned the English department rather than the English major.

Indeed, these four points actually represented a "Mission Statement of the English Department," not an overarching "Goal of the English Major" nor of the English curriculum (were a curriculum to identify one, all-encompassing goal). The four points stated the department's roles, functions, and intentions, but no what the curriculum intended to accomplish in its enrollees.

Following the putative "Goal of the English Major," the next bold headline in this curriculum announced the "Course Requirements for a Bachelor's Degree in English" (p. 202). Given first, but without explanation, were general studies requirements which are generally outside the scope of this analysis. Warranting attention here, however, were two columns differentiating general studies requirements for two different degrees-one a Bachelor of Arts (B.A.), the other a Bachelor of Science (B.S.). Oddly, no explanation accompanied this unusual offering; no explanation to the student reader indicated the reasons for differing programs to earn a "Bachelor's Degree in English" (as the headline indicated).

Two critical differences marked the programs: the B.A. in English required 6-14 hours of "Foreign Language," including "Six hours at the 2000 level or above"; the B.S. did not require a second language, but it mandated 15 hours of "natural Science" in contrast to the 3-4 hours required in the B.A. program. Slight difference existed in the 
number of electives, but both programs had considerable flexibility in their respective numbers (i.e., 35-54 for the B.A., and 38-48 for the B.S.). So their main differences centered on "Foreign Language" and "Natural Science' requirements. Without any clarification for these two differences, a student reader and potential consumer of this curriculum would have to infer reasons: Was the B.A. program to prepare students for graduate studies? Was the B.S. program to help students avoid foreign languages? Or, was it to meet state teaching requirements? Without an explanation of the programs and their purposes, the student reader would wonder why two existed; so, too, did this reader who ultimately found that state teacher certification programs (listed elsewhere in the catalog) did not mandate 15 hours of "Natural Science" for secondary English (pp. 167168). So, the reason(s) for two English degree programs could not be determined.

The "English Major" for each degree called for "a minimum of 36 semester hours in English," including six courses, of three hours each, and constituting a stable "core" of requirements:

ENGL 1301 Introduction of Language and Literature I

ENGL 1302 Introduction to Language and Literature II

ENGL 2301 World Literature I

ENGL 2302 World Literature II

ENGL 3305 Advanced Written Communication

ENGL 4302 Introduction to Linguistics (p. 203). Required to complete this "core" component of the major was "another 4000-level English course," chosen by the student, who also had to meet this mandate: "At least 24 semester hours of the required 36...must be upper level" (p.203). 
Structurally, the "core" of the Dallas Baptist University English major represented a traditional, tripod model slighting linguistics while emphasizing writing and literature. A single linguistics course appeared throughout the English curriculum: a senior level introductory course whose description included transformational grammar (p.257). Three writing courses, however, were required in the major "core." Two freshmen courses, commonly omitted from the major but included here, represented expository writing classes with the second focused on "selected literary works" (pp. 255-256). A junior level course entitle "Advanced Written Communication" (ENGL 3305) stressed the study of rhetoric and "discourse analysis theories," making three of six required "core" courses oriented to composition, and two of those three also attuned to literature. Additionally, two world literature survey courses at the sophomore level added weight to the literary "leg" of the tripod. Finally, whatever senior level course a student chose to complete the core would have weighted the curricular tripod to literature or writing. In short, the tripod of "core" courses stood askew with linguistics minimized.

Beyond the "core" to the extended curriculum, the influence of literature intensified to dominate the English curriculum. Twelve of the 14 "non-core" courses listed represented studies in literature. Only one of the fourteen definitely dealt with writing: senior level "Creative Christian Writing" (ENGL 4307); another, a junior level "Seminar in English" (ENGL 3315), may have involved writing as it was "designed as a capstone class for the English major" (p. 256). Undoubtedly, with such weight given to literary studies, this English major curriculum represented a type "1" in Stewart's Modified Curriculum classification. 
Further content analysis of the Dallas Baptist University English curriculum showed that literary surveys dominated its 2000 and 3000 level course offerings, and their numbers appeared imbalanced. Two courses only appeared at the sophomore level: World Literature I and II, both surveys of world classics reported in terms of Western literature (e.g., "through the Renaissance" and "from the Enlightenment"). At the junior level, six courses were listed. Four represented surveys of Western literature: American Literature I and II, and British Literature I and II. In sum, six of the eight courses offered at the 2000 and 300-levels were literary surveys, and most were offered at the junior level.

At the senior level, the curriculum proliferated. It listed eleven course offerings, although one most be omitted from this discussion; namely, an education seminar entitled "English Language Arts and Reading 8-12." The ten remaining courses at the 4000-level of the English curriculum suggested (a) a vestige of the field coverage principle, and (b) a slight expansion in the periphery of the curriculum. First, the vestige showed itself in the title of a course: "ENGL 431—Victorian Prose and Poetry" appeared singular, without any other similarly title period course in the Dallas Baptist Undergraduate 2002-2004 Catalog. But in the 1997-1999 university catalog, that same course appeared with other period courses: ENGL 4304-Modern Drama; ENGL 4309-The Novel before 1900; ENGL 4311-Modern Poetry; and ENGL 4313-Modern Novel (pp. 215-216). Between 199 and 2002, these other courses lost their time or period references and became titled "Studies in " genre courses. Only the Victorian terminology persisted, a vestige of a curriculum organized by literary periods. 
Evidence suggestion a slightly expanding periphery of courses appeared with the description of ENGL 4313-C. S. Lewis," One of the three major authors' courses. The first, "ENGL 4308-Milton and Bunyan," received terse treatment in its description: "Major works of Milton and Bunyan," received terse treatment in its description: "Major works of Milton and Bunyan well be studied as examples of Puritan literature" (Undergraduate Catalog 200-2004, p. 257). The second, "ENGL 4312-Shakespeare" received rather perfunctory and unimaginative treatment: "A study of representative histories, comedies, and tragedies by Shakespeare with attention to the sources and backgrounds of his plays and significance of his work" (p. 258). The third, "ENGL 4314-C. S. Lewis," received the longest, most specific, and most imaginative description: "The course will acquaint students with a wide range of C. S. Lewis's works. The students will be called upon to respond, in oral and written formats, to his literary works. Students will also explore the idea of a shared literary fellowship as modeled by the Inklings" (p. 258). The length, specificity, and creativity of this description suggest that it was not written at the same time nor by the same writer as the Milton and Shakespeare descriptions.

Another hint that the "ENGL 4314 C. S. Lewis" course expanded the periphery of this English major can be inferred from the course listing in the 1997-1999 university catalog: there, the Lewis study concluded the list of English course offerings (p. 216). In the 2002-2004 catalog, the Lewis course occurred in the next-to-last place, followed by "ENGL 4315-Studies in Non-Fiction," a recent addition to the genre course offerings. 
This observation segues well into three rather broad concerns about the scope and sequence of the Dallas Baptist University English major curriculum: (a) the imbalance of course offerings; (b) the assignment of levels; and (c) the discrete categories of offerings.

\section{Dordt College (IA) Analysis}

Dordt College, "an institution in the Reformed theological tradition," located in Sioux City, Iowa, reports an enrollment "around 1400" (Dordt College 2001-2002 Catalog, pp. 4 \& 6). An unusual academic feature of this college appears in its assigning course numbers through the 390 s, omitting the 400 s (but beginning graduate studies with the 500s). Thus: courses often located at the upper level 400 s, such as independent studies, list at Dordt in the 390s.

The English major curriculum receives no introduction, no goals nor objectives, but begins with a code phrase, "General Major--." This indicates that the program leads to a Bachelor of Arts degree. Then the "Core" courses appear for a total of 18 semester hours (as each course equals 3 credits):

- English 201 American Literature (Note: To Whitman)

- English 202 American literature (Note: From 1860 onward)

- English 210 Approaches to Literary Study

- English 314 Earlier British Literature (To Bunyan)

- English 316 Later British Literature (Through late 19th Century)

- English 318 Modern British Literature (20th Century

Following this very British-American Literature core appears a directive that "Students must select one [of two] emphases": Literature or Writing (each equaling 18 or more hours).

The Literature Emphasis beyond the core calls for "six courses beyond English 200 or five courses beyond English 200 and one from Theatre Arts 265, 266, or 267" for 
a total of 18 hours. Presumably, these courses would be literary in content; the three theatre options represent history and literature courses rather than performance courses. A student choosing this emphasis would have 12 courses in literary studies; four or more would be surveys, and as many as eight could be genre studies for a 36-hour major.

The Writing Emphasis at Dordt represents a more varied program. Beyond the core of literary courses appear the following requirements/choices with their semester hours in parentheses:

- "two courses beyond English 200" (4-6)

- English 335 History of the English Language (3) or English 336 English Grammar (3)

- Communication 241 Introduction to Journalism (3)

- Communication 242 Print Journalism (4) or Communication 246 Advanced Journalism Production (3) or Communication 256 Advanced Reporting (4) or "two courses beyond English 200" (4-6)

- "four courses from

English 301 Advanced Expository Writing I (3)

English 302 Advanced Expository Writing II (3)

English 303 Reading and Writing of Poetry (3)

English 304 Fiction Writing (3)

Theatre Arts 380 Playwright's Workshop (3)"

- English 393 Individual Studies (1-3)

The writing emphasis is not only more varied than its literature counterpart, it also is more demanding in its total hours-unless I have misread the catalog listing which (to save space?) is crammed into three lines making the requirements for this emphasis difficult to decipher. (What! Is this list anything but an olio?!)

Following this difficult-to-read listing are several recommendations geared to different audiences. All English majors are encouraged to enroll in English 312 
Shakespeare and Elizabethan Drama (3), and in a foreign language course numbered 201 or above; Canadian students are urged to enroll in English 205 Canadian Literature (3); and, students who may pursue graduate studies are urged to take English 333 History and Theory of Literary Criticism (3).

Why did I assign this major curriculum to Type 1.5 of Stewart's Modified System? Did I err? The 1.5 type means the curriculum consists primarily of literature courses, but has some flexibility in requirements; the 2.0 type means it is more flexible and includes related studies. I may have erred. However, my "First Reading Card" shows that 22 of the 31 courses offered represent literature or literary courses. Further, if a student elected the literature emphasis, her major would consist of 36 hours of only literature. If she elected the writing emphasis, her major could have as many as 28 hours of literature. So, I must have decided on my initial reading of this curriculum that its heavier orientation to literature merited a 1.5 assignment.

What do I see as I journal about the Dordt College English major curriculum today (after several hours of living with it)? I shall answer in order of my research questions.

1. The nature and state of this curriculum-It represents a literature dominated program whose core requirements remain American and British literature. The latter, the British survey, outranks the other surveys of American, ethnic American, Canadian and world literature. The later list appears at the 200 level while the former appears at 300 . Above its surveys are courses in the novel--equally British and American. Genre courses total 5 , and all but one represent fiction; the exception is a hybrid literary and writing course for poetry. Vestiges of the field coverage model remain in the required (American 
and British) literature surveys, while the presence of other literatures as electives (ranked at the 200-level only) show peripheral accretion. (This paragraph needs revision and clarity, but I am speed-writing.)

2. The state of this curriculum-The major with a literature emphasis represents the old paradigm —-the tripod English major dominated by literature. The major with a writing emphasis represents a confusing olio of courses begrudgingly oriented to writing or journalism or literary writing, with a touch of the practical (namely, English 305 Business and Technical Writing. The touch is slight, without other related entry-level offerings such as editing.)

3. Evidence of Christian thought-Four course descriptions refer to Christianity: (a) The English 202 American Literature (II) description declares, "Students will be expected to respond to the literature from their own Christian point of view"; (b) English 304 Fiction Writing indicates consideration will be given to "the ways in which one's faith affects the work of writing fiction" (Note: The context of the words "one's faith" here is indisputably Christian); (c) English 314 Earlier British Literature states, "Special attention will be paid to the Scriptural tradition which this literature [of Chaucer, Spenser etc.] evokes"; (d) English 333 History and Theory of Literary Criticism includes "the aim of formulating clearer Christian theories of literature."

In addition to these direct mentions of Christianity, the curriculum lists many writers whose works involve Christian ideas. For example, these names appear: Dante, Bunyan, Donne, Hawthorne, Bronte, Eliot, Walker, and Woiwode.

So: The Dordt College English major curriculum shows convincing evidence of Christian influence. 
Strengths: See above re literary dominance and Christian influence.

Weaknesses: See above re lack of goals, objectives, and clarity for the writing emphasis program whose olio listing indicates a lack of clear mission and purpose.

\section{Gordon College (MA) Analysis}

Gordon College located in Wenham, Massachusetts, reports in its Academic Calendar 2001-2002 an enrollment of 1,528. Identifying itself as "the only interdenominational Christian liberal arts college in New England," Gordon houses its English program in the Department of Language and Literature in the Humanities Division. Although its English major represents a veritable literature program, its curriculum package looks as it were a Stewart's Modified Category 1.5. (I will elaborate further below.)

After the department faculty names appear, "Requirements for the Major in English" (40 Credits) appears in a boldface, sans serif headline. An introductory course, EN 202 Introduction to the Study of Language and Literature, appears beneath that encompassing headline. Then the first of three smaller, boldface headlines clearly divide the English major into three components.

"British and American Literature" (12 Credits), the first component, lists 7 courses but directs the student major to elect three from among these (four semester hour) courses:

- EN 238 Victorian Literature

- En 244 Early American Literature

- En 330 Milton and the Seventeenth Century

- EN 332 Classicism and Romanticism

- EN 336 Twentieth-Century British Literature

- EN 246 Modern American Literature 
- EN 348 Contemporary American Literature

Clearly, this component reflects a field coverage model of literature redolent of mid-twentieth century English curriculum.

"Comparative Literature (12 credits)," the second component, directs the student to choose three from among these (four semester hour) courses:

- EN 262 Classical Literature

- EN 284 African Literature

- EN 321 Russian Literature

- EN 322 Irish Literature

- EN 360 Biblical Narrative

- EN 372 Shakespeare and the Renaissance

- EN 470 Chaucer and the Medieval Tradition

While the field coverage model contributes only three courses (namely, EN 262' EN 372; and, EN 470) to this component, a student major could select those three and continue taking period courses in British literature as if the traditional canon had never burst.

"Rhetoric, Theory and Composition (12 credits)," the third and last component of the Gordon English major curriculum directs students to choose three courses from among these (four credit hour) options:

- CO 222 Introduction to Journalism

- CO 324 Newspaper Features and Magazine Articles

- EN 214 Creative Writing: Fiction

- EN 215 Creative Writing: Poetry

- EN 312 Advanced Composition and Rhetoric

- EN 418 English Grammar and Syntax

- EN 420 Literary Criticism

The offering of rhetoric and composition appears too light, to me, for the title of this third component of the Gordon English major. 
The structure of this curriculum is tripodal, much like the old paradigm of English with its dominant literature "leg" and two abbreviated legs of composition and grammar. It is only clever packaging which disguises the old paradigm in this program: the misnomer "Rhetoric, Theory, and Composition" suggests that the Gordon major has integrated rhetoric, composition or writing into its program for greater balance to the tripod (if the tripod must be perpetuated). However, the writing offered includes two journalism courses (of seven), two creative writing courses, one advanced composition course, one grammar and syntax course (and, what does grammar have to do with the title of this third component?!) and the theory course does not concern composition, writing, or rhetoric! It addresses literature! Clever packing to disguise an outdated curriculum does not impress me favorably. But, onto my research concerns....

1. The nature of this curriculum-Seventy-five percent of the course offerings represent literature. British and American literature comprise from 12 to 24 semester hours of this major (depending on student choice), a number which electives could swell. The nature of this curriculum is pronounced: it is primarily a literature curriculum, with field coverage of British literature remaining pronounced.

2. The state of this curriculum-It perpetuates the tradition canon of literature; that is, this curriculum suggests that most authors are white males from the British Isles and North America. I recognize that the curriculum does offer other literatures, including African, Russian, and Irish (part of the British Isles?); however, they represent lower level classes at the 200 and 300 level, while most of the British literature courses occur at the upper 300 - or lower 400 -levels. 
3. The evidence of Christian thought-One course, EN 360, is entitled "Biblical Narrative," though in a less conservative school it might be named "The Bible as Literature." This elective, four-hour course addresses "major themes and characters from Old Testament and gospel narratives." Other courses evidently concern Christianity: EN 330 Milton and the Seventeenth Century would, of course, address Milton's theology (which has Arian tendencies) and his epic imagination of the fall and recovery of humankind. EN 348 Contemporary American Literature deals with "literature concerned with Jewish, Christian, feminist and minority issues." EN 470 Chaucer and the Medieval Tradition must be presented in the milieu(x) of "theological and philosophical contexts of Christian Middle Ages in Europe." So: The Gordon College English major curriculum shows evidence of incorporating Christian thought and/or issues within its literary courses.

Finally, the strengths and weaknesses of this major. Its intensity on literature represents a strength to anyone (like Harold Bloom) who would perpetuate the traditional canon (while the non-major, 100-level courses throw sops to change with such titles as “Women's Literature: International"). The inclusion of a 400 level course in literary criticism underscores the true nature of this curriculum.

Its weaknesses include a de-emphasis on composition, and the omission of rhetoric (above the non-major, 100-level of general study courses). EN 418 English Grammar and Syntax appears misplaced at the 400-level, particularly if it represents a "general introduction to linguistics." It appears, however, to be an olio course, that is, an indeterminate mixture of somewhat related subjects. Last, there is "a very little" practical, career opportunity to this curriculum: supervised tutoring at the 300-level, and an 
internship in journalism at the 400 -level represent the only practical experiences. (Would an English major quality for a 400-level internship in journalism?)

An emotional confession: I love the spring green and gold colors of the Gordon College catalog; and I enjoy trying, with my limited Greek, to translate its motto: "Jesus Christ: Only Begotten Son of God..." So, I dislike being harshly critical of the Gordon College English major curriculum! May God bless Gordon College!

\section{Goshen College Analysis}

Goshen College, a northern Indiana school which identifies itself as "a ministry of the Mennonite Church," enrolled 1,041 students during the 2000-01 academic year (Goshen College Catalog, 2001-2003). Its English Department then had six full-time members and one part-time member offering 22 English courses through a Stewart's Modified Type 2 curriculum_- that is, a curriculum emphasizing British and American literature while having some flexibility in the fulfillment of its requirements. What I realize after reading it closely is that the Goshen College English major curriculum has a distinctly Mennonite simplicity, economy, and directness (akin, perhaps, to the character of a Mennonite meeting place).

(Two notes: (1) Rather than using "akin" here, I nearly used "redolent," which does not suit the visual or aural simplicity of this curriculum. (2) I fear that I may not sustain the analogy I would draw; it may, like many a comparison of unlike quantities or qualities, break down under its own weight; Nevertheless, I will try in re-presenting this curriculum to suggest its true Mennonite character.)

The simplicity of the Goshen College English curriculum appears at first through its layout and design. Below a horizontal line at the top of an $81 / 2$ by 11 inch page, the 
title "English" stands centered above a list of faculty (presented by rank); then, another horizontal line separates that title and list from the two-column layout of the content. Boldface headlines in sans serif type font impress plainness subtly but definitely into the curriculum, much as the modern, wooden design at the focal point of Kern Road Methodist Church impresses itself against its surrounding plaster-plain walls. More important than the simple-but-impressive layout suggested above is the corresponding academic simplicity and focus. This major represents, despite its title, a literature major whose core (not labeled by that name) consists mainly of 300-level required courses $(\mathrm{N}=6$ or 7$)$, with one 200 - and one or two 400 -level courses. Nine elective hours in English surround that core, and 6 upper-level courses from among related studies (e.g., history, linguistics, TESOL) swirl about its structure. Little choice exist within the required core, except two: either a genre study or a major author; and, a senior project, student teaching or TESOL field experience.

Underscoring the lack of choices within the core of this English major curriculum is the "Planning guide" which immediately follows the requirements.

Its terseness appears in this (boxed) excerpt:

\section{Third year}

General education American Literature Survey British Literature to 1800

Related courses

This entry typifies the four. No extraneous words appear, nor any complicated alternatives. The plan and the major it represents are straight-forward lists without elaboration and with little qualification. 
within the required core, except two: either a genre study or a major author; and, a senior project, student teaching or TESOL field experience.

Underscoring the lack of choices within the core of this English major curriculum is the "Planning guide" which immediately follows the requirements.

Its terseness appears in this (boxed) excerpt:

Third year

General education

American Literature Survey

British Literature to 1800

Related courses

This entry typifies the four. No extraneous words appear, nor any complicated alternatives. The plan and the major it represents are straight-forward lists without elaboration and with little qualification.

Also underscoring the simplicity of this English (literature) curriculum is its lack of an introduction, of any goals or objectives, or any promotional feature (such as studies in Britain or internships in publications). Other departments have introductions, objectives, and some features; the English major does not. It opens with a "Major in English" boldface headline, and closes without comment at the end of the planning guide.

Three minors augment the English major: a writing minor consisting of 18 hours in communication and English, a TESOL minor of 20 hours in English and the humanities, and a literature minor of indeterminate hours (probably 18-20) but with an apparent emphasis on international and interdisciplinary literatures. International literature might readily be renamed world literature, and (as it does in many other 
schools) it carries a low 200-level number. Interdisciplinary literature, however, offers a number of potential literary studies listed as Engl 207 and/or 307. Topics include these:

- $\quad$ Irish Literature in Ireland (during May or summer terms)

- American Indian Literature

- $\quad$ African-American Literature (hyphenated in the GC catalog)

- $\quad$ Creative Writing in the Natural World (a literary and writing course)

- Mennonite Literature

- Women in Literature

This use of two course numbers at sequential class levels to offer 6 literature courses suggests the Mennonite value on economy in this curriculum extends beyond the terseness of its planning guide.

Another instance of economy shows with Engl 306 Major Author, in which Shakespeare enjoys every-other-year appearances but still shares billing with "Yeats and Women, Faulkner and Morrison, Vonnegut, and O'Connor" (GC Catalog, p. 46). Could English faculty have had administrative pressure to avoid the multiplication of course offerings?

Economy also characterizes Goshen College English course descriptions. While these are not as bare-bone and vague as those in the Malone College English major curriculum, these descriptions stand in terse sentence fragments. A typical example appears (boxed) below, which also represents an Engl 207 or 307 topic unique to Goshen College:

Mennonite Literature. Recent literature--mainly poetry and fiction-by U.S. and Canadian Mennonite writers, studied in relation to Mennonite history, culture and theology. Authors include Rudy Wiebe, Sandra Birdsell, Armin Wiebe, Julia Kasdorf, Janet Kaufman, Jean Janzen, Jeff Gundy and others. (GC Catalog, p. 46) 
Beside economy, directness characterizes the English major curriculum at Goshen. Two instances will have to serve as support for this assertion, as directness is a characteristic not warranting in depth exploration. First, the one directive given to the student majoring in English states: "In general education, English majors should choose Phil[osophy] 300" (p. 44). Second, the notice given in the literature offerings section declares: "Except for Senior Seminar and Project, all literature courses are designed to serve the general student as well as the English major" (p. 46).

This last declaration provides an apt segue into the strengths and concerns (or, weaknesses) which I see within the Goshen College English major curriculum. The foremost strength I posit may be inferred from my thesis statement: This curriculum reflects its Mennonite heritage by its simple, economical and direct character. The inclusion of Mennonite literature among its interdisciplinary literary courses underscores the match between this curricular plan and its intended clientele.

Other than "Mennonite history, culture, and authors," however, little mention of Christian thought appears in this curriculum. Names associated with Christian-oriented texts appear within its courses; these include, for examples, Milton, Hawthorne, and O'Connor. However, no mention of C. S. Lewis or his group "The Inkling” appears within the curriculum. To me, this represents a concern.

Other concerns include the lack of goals and objectives; the heavy concentration of English courses at the 300-level and corresponding need for additional hours at the 200 and 400 levels; the lack of practical course work and opportunities (such as an editing course); the omission of rhetoric and the slight attention given composition; the omission of grammar, linguistics, and/or history of the English language; and, the omission of 
literary history or criticism. Finally, the notice that all courses except the (three) $400-$ level ones "serve the general student as well as the English major" alarms me. These concerns contrast significantly to the simple, economical and direct character of the Goshen College English major curriculum.

\section{Lee University (TN) Analysis}

VIP: I have reassigned the Lee University English major to Stewart's Type1.0, due to the content being $80 \%$ literature, but originally I had given this curriculum a 1.5 (with a note that it nearly was 1.0). Why did find this curriculum so impressive that I could hardly wait to analyze it, and for that reason kept it for the last of the 20 selected curricula to treat? I think that both its classic layout-design and its "serving" tone explains my enthusiasm; both appear through the use of a(n): disciplines;

- Department page with a photo, list of faculty (by rank) and a list of

- Department introductory paragraph with its mission, majors and affirmation of "the lordship of Jesus Christ";

- Discipline introductory paragraph for English with a tone emphasizing service to students in their preparing for graduate study, careers, and "integrating their Christian faith with scholarship in the discipline";

- Listing of "Programs of Study" with their codes identified

- Listing of the curricular requirements for the "Bachelor of Arts in English" (and a very clear listing, too!) (pp. 159-161).

The program for this major has four sections - each capitalized to indicate its category in the listing (and each subtotaled): (1) "Specialty Area Requirements" (36 semester hours); (2) "General Education Requirements" with a note regarding any requirement pertinent especially to the English major (47); (3) "Religion Requirements" again, with a note pertinent to this major (15); and, 4) Electives (32). The total hours for this program appear at the close: 130 semester hours. 
The "Specialty Area Requirements" represent a literature program rather evenly given to English (i.e., British), American, and world literatures. Each requires two survey courses at the 300 level; British literature enjoys ENG 410 Shakespeare, while American and world literatures do not have any 400-level counterparts. One "Advanced Grammar" (ENG 482) course, dealing primarily with theories of grammar rather than low-level grammatical usage, is required; a "Writing about Literature" (ENG 300) heads the list of requirements, and a capstone-like course entitled "English in Christian Perspective" (ENG 495) completes the required list of courses (except that 3 hours of electives are allowed under this category).

So: The Lee University English major appears to be solidly literature as evidenced by its required courses. Its course offerings confirm this as they reflect the historical coverage of literature by period and author: I am not going to support this observation here in this abbreviated analysis, other than to observe that the 400-level courses especially reveal this traditional coverage approach (with allowance for genre and major author courses): for examples,

- ENG 405 The American Novel

- ENG 406 The British Novel

- ENG 410 Shakespeare

- ENG 415 Milton

- ENG 431 English Romantic Period

- ENG 441 Victorian Literature (and the list continues through two modern literatures).

The presence of numerous elective courses suggest what Graff and others have called the swelling periphery. Among these are courses in women writers, southern fiction, and special topics (to meet new issues and demands?). All these peripheral 
electives are listed at the 400 level, another indication that they extend beyond the pale of traditional, core, literary courses.

But ENG 495 English in Christian Perspective serves as a required course in the core, and I want to quote its content to stress its apologetic nature:

Through readings, oral discussion, a journal and a paper, English majors are assisted in the integration of the various facts of the major in relation to fundamental disciplinary concepts and overarching philosophical, theological, and ethical concepts, guided by Christian perceptions of truth. (pp. 171-172)

This paragraph continues the tone of "serving" the students who major in English at Lee University.

Regarding research question 1: The above notes suggest that this literature program gives nearly equal weight, at the 300 -level core courses, to British, American and World Literatures; that it shows the historical coverage model at the 400 level; and, that it has expressed concern for its students to have the opportunity to integrate their learning with Christian perspectives.

Regarding research question 2. Introductory statements point to the importance of students integrating Christianity and their studies. Two courses specifically stress that integration: ENG 325 Literature of the Bible (3), an elective course; and ENG 495 English in Christian Perspective (3), a required course.

Strengths: Clarity of purpose and presentation represent two interrelated strengths to the English major curriculum at Lee University; another is the "serving" tone of its written copy. Giving world literature two core courses represents another plus. This program lays an excellent foundation in literature for any student planning to do graduate study. The stress on opportunities for the integration of Christianity and knowledge is a definite plus! 
Weaknesses: The slighting of composition, rhetoric, and linguistics represents one veritable concern for students who plan to do graduate study; the omission of theater and film studies is less significant, but unfortunate.

Another note relates to the tone or sound of this curriculum: Few directives appear in this presentation, but when they do their tone is matter-of-fact and informative. For instance, this statement concerns the general education requirements: "This [English major] program requires 6 hours of foreign language at the intermediate level" (p. 161). If I were a student reading this curriculum, I would feel informed and respected.

\section{Malone College (OH) Analysis}

Malone College, affiliated with the Evangelical Friends Church and numbering 2100 students according to its 2001-2002 catalog, houses its English programs within the Department of Language and Literature. The sectional page for English and other, related programs begins (in boldface print!) with an alphabetical list of faculty; eight are fulltime faculty with appointments in English (according to a list given at the close of the catalog). Perhaps another faculty member with credentials in education teaches in the English education program (called "Integrated Language Arts"); at least, her name appears with the English and Spanish faculty $(\mathrm{N}=1)$.

Next: A general introduction to the department claims that study within it "prepares students to think analytically and to communicate articulately" (p. 87). Sounding lofty and global, this introductory opening emphasizes that Language and Literature "fields" help students to "define what it is to be human," through creative and critical thought on "the human experience" (p. 87). Thus, the initial paragraph of this introduction carries an idealistic tone, while it briefly describes it major programs as 
"Surrounded by a Christian atmosphere" (an introductory dependent phrase which awkwardly modifies "a major in English" rather than individuals studying English.

Can a program be "[surrounded] by a Christian atmosphere?). This phrase serves as a global, yet barebones descriptor, suggesting but not evidencing some influence of Christian thought.

The second paragraph broadly identifies "the [two] primary goals" of this department: "to enable students to read with insight and understanding, and to write with an awareness of audience, purpose, and context" (p. 87). Broad commentary, equating these goals with "objectives," follows:

The faculty accomplishes these objectives by introducing students to the foundations of literature, language, and writing, including traditional as well as non-traditional forms. (p. 87) (my italics)

No elaboration follows this claim. Rather another claim appears which states that persons majoring in the Language and Literature programs "benefit from a talented, friendly faculty who conduct classes in a dialogic and communicative manner..." (p. 87).

A final paragraph closes the introduction by referring to careers and graduate studies pursued by students who have majored in the departmental programs. Again, the information presented remains broad and general: "Graduates...have gone to professions in teaching, publishing and law, while others hold (sic) responsible positions in business, industry and government." (p. 87). This style of sweeping, global, general writing sounds as if the Malone College Catalog had been tweaked by a public relations writer. (My marginalia claims, "When I write like this, I do so to spoof the selling of Academia.")

Following this introduction, the "ENGLISH" program receives barebones treatment, beginning with a list of its "core curriculum for the major" (with the word 
"major" in boldface). The core calls for seven required courses, each counting three credit hours, and five representing junior level courses:

- ENG 205 An Introduction to English Studies (focused on literature)

- ENG 311 Expository Writing ("an advanced composition course")

- ENG 345 British Literature to 1798

- ENG 346 British Literature Since 1798

- ENG 355 American Literature to 1865

- ENG 356 American Literature Since 1865

- ENG 471 Applied Literary Theory

Some 24 to 25 additional hours are required to complete the English major. These must be taken among four categories, each of which has specific directives for its fulfillment. The four and their directives include:

1. World Literature. ENG 322 World Literature or THEA 330 World Drama are the options, each counting 3 credits.

2. Language Study. Two courses are required from this list: ENG 381 Introduction to Linguistics; ENG 38[3] History of the English Language; or course work (of 3-6 credits) at or above the 130 level in a foreign language.

3. Composition. One course among these is required: ENG 313 Expository Writing; 411 Advanced Rhetoric and Composition; or, THEA 431 Playwriting.

4. Electives. "The remaining 12-13 hours must be selected from a combination of 300/400-level courses with at least one 400 -level electives."

A concluding note under "Electives" explains that student majors choose electives "based on [their] interest and career goals" and with advisor input.

What does this core-and-categories curriculum create?

Its required core is solidly literature, mainly at the junior (300) level: 6 of its 7 courses represent literature courses (for a total of 18 hours); 5 of its 7 represent 300-level 
offerings. Its first required category lists either a 300-level world literature or world drama course, both surveys (for three additional hours in literature). Its second category requires two courses from these options: introductory linguistics (at the 300-level), history of the language (also at the 300-level), or foreign language courses at the 130 or higher level (for a total of 3-6 credits). Its third category requires one course among creative writing (at the 300-level), advanced composition (at the 400-level), or playwriting (at the 300-level). The final category calls for 12 to 13 hours of electives.

What electives remain — part from the choices listed among the four categories? Literary electives at the 300-level is the answer, as evidenced by this list:

- ENG 353 Shakespeare (3)

- ENG 360 Genre Studies (3) repeatable up to $6 \mathrm{w} /$ different subtitles

- ENG 365 Author Studies (3) ditto

- ENG 390 African American Literature (3)

- ENG 395 Women Writers (3)

- ENG 350/450 Advanced Topics (3)

- ENG 360 Advanced Studies in Literature (3)

The list recalls Graff's description of an enervated English major: a stolid core of literature courses (reflecting a former field coverage curriculum) is surrounded by an expanding periphery of electives (Professing Literature).

Asking myself the resultant loss (of this stolid, swollen program), I noted the scant role played by writing in this tired curriculum. It lacks, especially, these writing courses which support entry-level positions in the publishing world: technical writing, editing, feature writing and internships. While this curriculum needs such practical courses, it also needs a theory course for rhetoric and composition — the counterpart to ENG 471 Applied Literary Theory. Further, it has no writing-intensive course offerings. 
Beside its weakness in writing, this English major curriculum offers no journalism courses. Though several are available in the communication curriculum, they are not listed (as two theater courses are) as English electives. Nor are media nor public relations courses offered as English electives, although courses in both media and p-r appear in the communication curriculum. I cannot account for these omissions except to speculate on the English faculty's openness to change.

Skittering toward an ad hominum_argument, I review my First Look card to see what strength(s) I had previously noted in the Malone College English major curriculum. What I observed before, I confirm now with this in-depth analysis: its 300-level courses indicate variety among its literary electives. They include ENG 390 African American Literature, ENG 395 Women Writers (a rare find!), and ENG 350 (listed optionally as 450) Advanced Topics. Variety evidently characterizes the ENG 360 Genre Studies and 365 Author Studies courses (although specific descriptions and examples are omitted).

The obverse of this strength, however, is the imbalance of course offerings at the undergraduate levels. Four courses exist for 200-level studies, 15 exist for the 300-level, and only four for the $400-$ level. The latter concerns me most. With so few $400-$ level courses, how do Malone's English majors develop their critical thinking abilities to prepare for graduate and professional studies? If this curriculum persists, this weakness needs redressing.

Another weakness appears through the extraordinarily general course descriptions as evident in this boxed example: 


\section{ENG 365 (3)}

\section{Author Studies}

Intensive study of an author or group of authors. Subtitle will indicate course content. Repeatable, maximum 6 credits under different subtitles. Prerequisite: ENG 200 or 205. Offered every fall.

I wonder why specific details—-such as recently chosen authors--do not appear in this description? Which literatures, I ask, receive attention? Which receive emphasis? What does the course require of its students? What opportunities does it extend to students? (With apologies to Stephen Crane, I shout to the universe, "Sir, I insist: Ban barebones descriptors!" The universe, however, remains indifferent.)

Finally, I find no evidence of Christian thought in this curriculum (which, claims the introduction, is "[surrounded] by a Christian atmosphere"). It makes no specific mention of Christianity or Christian writers, although once it uses the phrase "religious contexts" (to describe ENG 322 World Literature). I trust that Christian thought has some role in the "taught curriculum," but I wonder just how pervasive that "Christian atmosphere" when it remains invisible in the official curriculum.

Let me add a methodological note: As I begin the analysis of each English major curriculum, I ask God to bless its college or university and to help me be perceptive and fair. As I use close reading and journaling to understand each curriculum, I continue to pray for perceptiveness and fairness. Finally, after I have written a description and analysis of a curriculum, I ask for divine blessing on the college it serves. 


\section{Northwest Nazarene University Analysis}

Northwest Nazarene University of Nampa, Idaho, reports in its Undergraduate Catalog 2001-2002 an undergraduate enrollment of about 1,000 undergraduate students and 250 graduate students. The Department of English, composed of six full-time faculty members, houses the English major. Faculty names precede the curriculum which begins with a short paragraph entitled "Academic Objectives.".

Its title serves as a misnomer as the content presents goals; further, the paragraph sounds in its content and tone much like a mission statement. "The English-Education (sic) major offers students an opportunity to experience American, British, and world literate," it states sweepingly. "[To] discover and develop an appreciation of ideas and values," the paragraph continues with its broad goals.. "[To] cultivate critical thinking," it continues, and "to develop a knowledge of the English language and its operation, and" in what sounds like an after-thought, it concludes, "to strengthen writing skills."

(Note: A number of the 20 schools whose curricula I have selected to study begin their curricula with sweeping, lofts goals, misidentified often as objectives; further they do not attempt to connect those goals to the English curricular requirements. Northwest Nazarene neglects to connect its "objectives" (actually, goals) with its long, rather cluttered listing of major requirements.

The English major at this Nazarene school earns a type 1.0 for Stewart's Modified Category; it strongly deserves being typed as a literature major for 32 of its 42 courses concern literature. Further, it is a literature major of the old paradigm: British and American literature account for more than 50 percent of its literature courses $(N=17$ of 32); A student could fulfill the core requirements, if he wished, with all British and 
American oriented courses (for literature) except for two courses-one course in the ancient Greek and Roman classics and one in world literature, European literature, or a foreign language literature.

This major retains many field coverage courses especially at the 300- and 400levels of instruction. Examples include the following, three-hour courses:

- EN 325 The American Novel: Inception to 1910

- EN 326 The American Novel: 1920 to the Present

- EN 332 Shakespeare

- EN 335 The British Novel: Beginning through Dickens

- EN 336 The British Novel: Hardy to the Present

- EN 432: Chaucer and His Age

- EN 433 Milton and His Age

- EN 434 Major Romantics and Victorians

Each of the above courses serves as a required course or one choice to fulfill a requirement for the Northwest Nazarene English major curriculum.

Does the structure of this curriculum then represent a core and periphery? model or a tripod model or another model of the undergraduate English major? The core-and periphery type does not fit unless the periphery appears as thin as the atmosphere surrounding Earth appears in relation to the sphere. The two contemporary courses for this nearly non-existent periphery are EN 391 Literary Criticism and EN 427 Minority Voices in American Literature. Imagine! The literary criticism course is not included among the major's requirements!

The tripod model better represents the structure of this curriculum, with the domineering "leg" of literature markedly greater than the abbreviated composition (here, writing/journalism) and grammar (here, linguistics) "legs."

As noted above, courses in literature number 32 . Courses in writing and journalism total five (and one represents an internship); courses in grammar and 
linguistics number four (and none treats the history of the English language). (Why does the total not equal 41 and not 42 as given above? The nature of the senior seminar course cannot be determined from its description; of course, it can be inferred to involve both writing and literary, but it may represent some other enterprise given to "the senior project.")

So: What is the nature of the English major curriculum at Northwest Nazarene University? It is a literature major relatively untouched by contemporary developments in English. It has no composition courses in writing/composition theory or rhetoric; it has one course in American minority literatures (to fulfill Idaho secondary teaching requirements, I suspect, from the listing of a children's literature course and a teaching language arts course among English courses. These latter two I have not included among the 42 counted for the non-teaching major.)

What is the state of this English major? It compares to the late 1960s major described by Wilcox in his national survey and later commentary $(1970,1973)$.

What about the presence of Christian thought in this curriculum? No mention of Christianity appears among the "Academic Objectives" (statement), nor directly in any course except EN 353 The Bible as Literature. Other courses including those given to Chaucer, Shakespeare, and Milton must address Christian thought (if only Milton's putative Arianism!), but their course descriptions do not identify Christian thought, issues, or (even) contexts.

Finally, I need to reiterate the strength(s) and weakness(es) I perceived as I completed the First Look and Claims Cards for the English major curriculum at Northwest Nazarene University. Its primary strength lies in its thorough treatment of 
British and American literature; simultaneously this represents its primary problem. This curriculum, like the fabled Saber-Tooth Tiger curriculum, is out-of-date.

\section{Seattle Pacific University (WA) Analysis}

Seattle Pacific University, a Free Methodist School claiming its "approach to education is informed by the ... 'Wesleyan Quadrilateral"' of scripture, tradition, reason, and experience, represents one of the larger CCCU members. Its total enrollment peaked at 3,524 in 1989, according to the SPU 2001-2002 under-graduate catalog which evidently omitted more recent figures (or I could not discover them). Whatever its student numbers, Seattle Pacific has the highest number of English faculty which I have yet recorded among the 20 schools selected for my study: 9 full-time faculty, plus a graduate dean who teaches part-time. No other part-time faculty appeared among "Additional Faculty" lists, unless any of the five English emeriti faculty remain active.

Enrollment and faculty numbers relate directly to the number of courses comprising the SPU English curriculum: 46 . Literature courses number 29, for 63 percent; writing courses number 13, for 28 percent of the English curriculum. With literature dominating this curriculum, its Stewart's Modified Type is 2; its emphasis on British and American literatures has a modicum of flexibility in its fulfillment. Of course, a curriculum with 46 courses warrants flexibility—but it also invites questions about faculty loads. But let me turn first to the question I asked myself earlier today after rereading this curriculum.

I asked, What impresses me most about the Seattle Pacific University English curriculum - that is, beyond the number and diversity of its literature courses? Why did I write in my cover-notation, "Excellent ENGL major w/ strong minors in WTG \& LIT"?" 
My answer today may be more restrained, but it remains positive: Its Christian orientation, intellectual vigor, and academic opportunities make the Seattle Pacific University English major curriculum impressive.

Its Christian orientation appears almost immediately in the introduction to Seattle Pacific English programs: "Literature courses show how language enables us to explore and shape our views of God"' (SPU Catalog, p. 129).

The major, it continues, "prepares students to enter professions such as the ministry, law, social work or medicine" and "to enter [one's adult] life with an appreciation for God's gift of language and literature" (p. 129). (Note: The introduction establishes the equation of literature and English for this program.)

Other evidence points to this curricular concern for Christian influence. Christian thought appears immediately - that is, the first of seven - under SPU "Objectives of the Major": "[To understand] the relationship between literature and the Christian faith, and gain insight into the study of literature as a means of clarifying one's own values" (p. 129). Christian influence shows next in the (boldface, italicized title of the SPU literary journal which offers (and from its position in this curriculum, lures!) students' internships; viz., Image: A Journal of the Arts and Religion. (Note: This appearance represents one of several student-attracting and p-r savvy features of this curriculum.)

Another evidence of Christian influence appears through course offerings: 3 (three!) course titles show definite concern for Christian thought and influence. These include ENG 1110 Literature and Faith; ENG 4661 The Best of C. S. Lewis; and ENG 4921 Directed Readings in the C. S. Lewis Circle. Two course descriptions refer to 
Christianity or spirituality: ENG 225 Practical Criticism states that it "Includes consideration of Christian approaches to criticism"; and, ENG 2230 Literature of American West refers to "the spirituality of writers" (SPU Catalog, p. 130). Many literature courses treat texts involving Christian themes and concerns; for three examples, ENG 3235 Literature of the American Renaissance includes works by Hawthorne and Dickinson, ENG 3246 World Literature: European includes Dante and Dostoevsky, ENG 3338 Contemporary Fiction includes [Flannery] O'Connor, and, ENG 3346 Literature of the English Renaissance includes Milton (pp. 130-131). Christianity must figure in other several courses, of course (such as those dealing with "The Arthurian Tradition" and African American Literature), but Christian thought appears emphasized in the ENG 42245 Senior Capstone Seminar (p. 131). There students study major texts such as Paradise Lost, Moby Dick, and Middlemarch wherein Christian thought and issues receive varied treatments.

The goals of the English curriculum, identified as "Objectives of the Major," give (as I wrote above) first regard to the integration of Christian faith and knowledge (without using that evangelical college "buzz" phrase). "To understand the relationship between literature and Christian faith" qualifies as the integration of the two. Following this are seven objectives (really, aims of goals which deal primarily with academics.

The academic vigor of the SPU English major curriculum, which I have categorized as a Stewart's Modified type 2 (consisting mostly of British and American literature, but having flexibility in its fulfillment), proves evident through the following features: 
1. Admission into the major itself requires a student to have earned 2.5 (on a 4.0 standard) in two of four sophomore level courses;

2. Two courses concern literary criticism and theory, one at the sophomore level (entitled "Practical Criticism") and one at the senior (entitled "History of Literary Theory").

3. Several courses at the junior and senior levels represent writing intensive courses, including ENG 3246 World Literature: European and ENG 4225 Senior Capstone Seminar.

4. Theory courses for both literature and writing appear at the senior level.

5. Numerous electives in literatures from other cultures appear including literatures of Asia, Africa, Russia, France, German, and Latin America. Courses in these and other literatures are listed primarily at the junior and senior levels.

6. Nearly half of the 63 quarter hours required in the English major must be in upper-division courses (specifically 30 of 63).

Beside these features of the curriculum, course content points to a thorough grounding in literature, particularly in British and American literatures. A sketch (below) of the SPU English major, shows its core-and-periphery structure with these two literatures dominating all layers except the true periphery. Surely, this English major could be called the literature major since only one writing course is required, and that is ENG 2225 Practical Criticism: Writing and Research and its focus falls on writing about literature.

This focus and the depth offered in literature by this curriculum (which, of course, bears evidence of having evolved from a field-coverage model of literature) makes this 
an intellectually challenging major in the tradition of "English" equaling "literature," especially British and American literature.

Supporting that intellectual vigor in literary studies are three academic opportunities not usually found in the English major curricula of smaller schools: 1) a literary journal published by SPU university; 2) a biannual study-in-Britain quarter offered, with courses taught by SPU faculty; and, 3) a practicum and two internship courses at the 4000 -level and (all) repeatable for varying credits.

These academic opportunities conclude my argument that the SPU English major curriculum represents an intellectually vigorous study characterized by Christian thought. That conclusion, however, does not address what the SPU English major curriculum treats less concertedly or omits altogether.

In fact, I have several concerns about this English major curriculum; foremost of them is that its focus on the literary means it pays little attention to other dimensions comprising contemporary English studies. The major slights grammar and linguistics, devoting only one course to applied grammar and one to the history of the English language. As neither of these two courses represents a core requirement; an English major at SPU could graduate without having studied the nature and evolution of Modern English.

She could graduate, too, without having studied rhetoric even if she had fulfilled requirements for the writing minor (a 30 quarter hour program which, oddly enough, demands a history of the English language course when the English major does not!). Rhetoric does not appear among English electives; an English major student would have 
to turn to the communication program to study rhetoric-an increasingly important area of contemporary English studies.

A final concern I have remains with the possibility of faculty teaching too many courses and too many hours each quarter. Eight full-time English faculty members and one or two adjuncts divided among 46 courses suggests that some faculty have heavy loads, courses may not be offered often, or additional part-time faculty teach (other than the two listed; perhaps English emeriti or English faculty-turned-administrators teach). 


\section{REFERENCE LIST}

Applebee, A. (1996). Curriculum as conversation: Transforming traditions of teaching and learning. Chicago: University of Chicago Press.

Armstrong, P. B. (1990). The English coalition and the English major. ADE Bulletin, 96, 30-33.

Association of Departments of English. (2003, Spring-Fall). The undergraduate English major. ADE Bulletin, 134-135, 68-91.

Balch, S. H., \& Brasor, G. C. (2001). Losing the big picture: The fragmentation of the English major since 1964 [Electronic Version]. Academic Questions, 14(2), 6184.

Barge, L. (1994). Toward a Christian pedagogy for teaching literature. Faculty Dialogue, 22, 43-57.

Berlin, J. A. (1996). Rhetorics, poetics, and cultures: Refiguring college English studies. In S. M. North (Ed.), Refiguring English studies. Urbana, IL: National Council of Teachers of English.

Bethel College catalog, 2001-2002. (2001). St. Paul, MN: Bethel College.

Berthoff, A. E. (1999). Symposium: Reclaiming the active mind. College English, 61(6), 671-680.

Berube, M. (2002). Days of future past. ADE Bulletin, 131, 20-26.

Branca, G. S. (1994). The charms of curriculum change at Merrimack College. $A D E$ Bulletin, 108, 6-10.

Bulletin of Wheaton College 2001-02. Wheaton, IL: Wheaton College.

Calvin College catalog, 2001/2002. (2001). Grand Rapids, MI: Calvin College.

Colorado Christian University academic catalog, 2001-2002. (2001). Lakewood, CO:

Colorado Christian University. 
Council for Christian Colleges and Universities. (2000). Christian colleges \& universities: Profiles of leading colleges that emphasize academic quality and spiritual growth ( $7^{\text {th }}$ ed.). Lawrenceville, NJ: Peterson's.

Council for Christian Colleges and Universities. (2001). About the CCCU: Alphabetical listing of member colleges \& universities. Retrieved October 9, 2001, from http://www.cccu.org/about/listmembers.asp.

Council for Christian Colleges and Universities. (2001). About the CCCU: History. Retrieved October 9, 2001, from http://www.cccu.org/about/listmembers.asp.

Cowan, E. W. (1975). Options for the teaching of English: The undergraduate curriculum. New York: Modern Language Association.

Culler, J. (2003). Imagining the coherence of the English major. ADE Bulletin, 133, 6-10.

Dallas Baptist University 2002-2004 undergraduate catalog. (2002). Dallas, TX: Dallas Baptist University.

Dordt College 2001-2002 catalog. (2001). Sioux Center, IA: Dordt College.

Easton, L. P. (2002). Disciplining a working subject: An examination of English curriculum at two English Canadian community colleges. Dissertation Abstracts International, 63(06), 2102. (UMI No. 727399651)

Edmonds, C. F. (1994). Close reading. In A.C. Purves (Ed.), Encyclopedia of English Studies and Language Arts (pp. 194-195). New York: National Council of Teachers of English.

Eisner, E. W. (1969). Instructional and expressive objectives: Their formulation and use in curriculum. In W. Popham, E. Eisner, H. Sullivan, \& L. Tyler (Eds.), Instructional objectives. A.E.R.A. monograph series on curriculum evaluation, no. 3. Chicago, IL: Rand McNally.

Eisner, E. W. $(1979,1985)$. The educational imagination: On the design and evaluation of school programs. New York: Macmillan.

Eisner, E. W. (1991). The enlightened eye: Qualitative inquiry and the enhancement of educational practice. New York: Macmillan.

Eisner, E. W.(1992) Curriculum ideologies. In P. W. Jackson (Ed.), Handbook of research on curriculum (pp. 302-326). New York: Macmillan.

Eisner, E. W. (1994). Cognitions and curriculum reconsidered ( $2^{\text {nd }}$ ed.). New York: Teachers College Press. 
Eisner, E. W. (2002). What can education learn from the arts about the practice of education? Journal of Curriculum and Supervision, 18(1), 4-16.

Elbow, P. (1990) What is English? New York: Modern Language Association.

Evangel University catalog 2001-2002. (2001). Springfield, MO: Evangel University.

Eastern Mennonite University undergraduate catalog 2001-2002. (2001). Harrisonburg, VA: Eastern Mennonite University.

Fleishman, A. (1995). The condition of English: Taking stock in a time of culture wars. College English, 57(7), 807-821.

Fleming, D. (1998). Rhetoric as a course of study. College English, 61(2), 169-191.

Flinders, D. J., \& Eisner, E.W. (1994). Educational criticism as a form of qualitative inquiry. Research in the teaching of English, 28(4), 341-357.

Francus, M. (2001). Design and consent: Notes on curriculum revision. Profession 2001, 149-160.

Gannett, C. (1994). Journal writing. In A.C. Purves (Ed.), Encyclopedia of English studies and language arts (pp. 681-683). New York: National Council of Teachers of English.

Gordon College academic catalog 2001-2002. (2001). Wenham, MA: The United College of Gordon and Barrington.

Goshen College catalog 2001-2003. (2001). Goshen, IN: Goshen College.

Grady, H. (2001). Shakespeare criticism, 1600-1900. In M. DeGrazia \& S. Wells (Eds.), The Cambridge companion to Shakespeare (pp. 265-278). Cambridge: Cambridge University Press.

Graff, G. (1987). Professing literature: An institutional history. Chicago: University of Chicago Press.

Graff, G. (1992). Beyond the culture wars: How teaching the conflicts can revitalize American Education. New York: W. W. Norton.

Greenblatt, S., \& Gunn, G. (Eds.). (1992). Redrawing the boundaries: The transformation of English and American literary studies. New York: Modern Language Association. 
Harris, C. B. (1986). The ADE ad hoc committee on the English curriculum: A progress report. ADE Bulletin, 85, 26-30.

Harris, C. B. (1988). Canonical variations and the English curriculum. ADE Bulletin, 90, 7-12.

Heller, S. (1992). The curriculum. Chronicle of Higher Education. 38(31), 1, 9.

Houghton College 2001-2002 catalog. (2001). Houghton, NY: Houghton College.

Huber, B. J. (1992). Today's literature classroom: Findings from the MLA's 1990 survey of upper-division courses. ADE Bulletin, 101, 36-50.

Huber, B. J. (1996). Undergraduate English programs: Findings from an MLA survey of the 1991-92 academic year. ADE Bulletin, 115, 34-73.

Huber, B. J., \& Laurence, D. (1989, Fall). Report on the 1984-85 survey of the English sample: General education requirements in English and the English major. $A D E$ Bulletin, 93, 30-43.

Huber, B. J., \& Young, A. (1986). Report of the 1983-84 survey of the English sample. ADE Bulletin, 84, 40-61.

Jackson, P. W. (1992). Conceptions of curriculum and curriculum specialists. In Handbook of curriculum research (pp. 3-40). New York: Macmillan.

Journet, D. (2001) Redefining the mission of the English department at the University of Louisville: Two years later. Profession 2001, 130-136.

Jupp, V. (1996). Documentation and critical research. In R. Sapster \& V. Jupp (Eds.), Data collection and analysis. London: Sage.

King College academic catalogue 2001-2002. (2001). Bristol, TN: King College.

Klein, T. D. (1983, Spring). Revising the English major. ADE Bulletin, 74, 28-32.

Laff, N. S. (1998). Seeking the elusive/illusive English major. The CEA Critic, 61(1), 617.

Lawrence, K. (1988, Fall). Curriculosclerosis: Or, hardening of the categories. $A D E$ Bulletin, 90, 13-17.

Lee University undergraduate catalog 2001-2002. (2001). Cleveland, TN: Lee University. 
Lincoln, Y. S. 1992). Curriculum studies and the traditions of inquiry: The humanistic tradition. In P. W. Jackson (Ed.), Handbook of research on curriculum (pp. 7997). New York: Macmillan.

Lloyd-Jones, R., \& Lunsford, A. A. (1989). The English coalition conference: Democracy through language. Urbana, IL: National Conference of Teachers of English.

Long, C. S. (1994, Fall). Re-vision-inside, outside, upside down: Curriculum change at Willamette University. ADE Bulletin, 108, 11-15.

Lovejoy, D. W. (1973). Assessment of a remedial English program for academically disadvantaged young adults at. Western Christian College. Unpublished dissertation. Michigan State University. (AAT 7406082) Retrieved from ProQuest Digital Dissertations.

Lundin, R. (2002). What we make of a diminished thing: Religion and literary scholarship. In A. Sterk (Ed.), Religion, scholarship, \& higher education: Perspectives, models, and future prospects (pp. 89-116). Notre Dame, IN: University of Notre Dame Press.

Malone College catalog 2001-2002. (2001). Canton, OH: Malone College.

Madus, G. F., \& Kellaghan, T. (1992). Curriculum evaluation and assessment. In P. W. Jackson (Ed.), Handbook of research on curriculum (pp. 119-154). New York: Macmillan.

Manning, P.K., \& Cullum-Swan, B. (1994). Narrative, content, and semiotic analysis. In Denzin \& Y. S. Lincoln (Eds.), Handbook of qualitative research (pp. 463-477). Thousand Oaks, CA: Sage.

Mason, J. B. (1994). Heeding our strokes: Curriculum revision at Western Washington University. ADE Bulletin, 108, 16-18.

McEwan, H. (1992). Five metaphors for English. English Education, 24(2), 101-128.

McMillen, D. J. (1993, Autumn). Review of the book $A$ history of the Bible as literature: From 1700 to the present day. Christianity and Literature, 43, 95-96.

McQuade, D. (1992). Composition and literary studies. In S. Greenblatt \& G. Gunn (Eds.), Redrawing the boundaries: The transformation of English and American literary studies. New York: Modern Language Association.

Miller, J. P., \& Seller, W. (1985). Curriculum: Perspectives and practice. New York: Longman. 
Moffat, W. (2003). Figure and ground: The transformation of the Dickinson College English department's faculty and curriculum. ADE Bulletin, 133, 11-14.

Morrissey, W., \& Fruman, N. (1993). Ideology and literary studies, Part II: The MLA's deceptive survey [Electronic version]. Academic Questions, 6(2), 46-59.

Murphy, P. M., \& O'Shea, E. (1997, Spring). Curriculum revisions: Notes of the MLA FIPSE process at the State University of New York. ADE Bulletin, 116, (41-45).

Northwest Nazarene University undergraduate catalog 2001-2002. Nampa, ID: Northwest Nazarene University.

Oklahoma Christian University academic catalog 2001-2002. (2001). Oklahoma City, OK: Oklahoma Christian University.

Palm Beach Atlantic College undergraduate and graduate catalog 2001-2002. (2001). West Palm Beach, FL: Palm Beach Atlantic College.

Peck, D. (1969). A survey and analysis of the undergraduate English programs in the liberal arts colleges affiliated with the United Presbyterian Church in the USA. Unpublished doctoral dissertation, University of Nebraska, Lincoln.

Pinar, W.F., Reynolds, W. M., Slattery, P., \& Taubman, P. M. (2004). Understanding curriculum: An introduction to the study of historical and contemporary curriculum discourses. New York: Peter Lang.

Rabinowitz, P. (1994). Canons and close readings. In D. Richter (Ed.), Falling into theory: Conflicting views on reading literature (pp. 218-221). Boston: Bedford.

Raymond, J. C. (Ed.). (1996). English as a discipline; Or, is there a plot in this play? Tuscaloosa, AL: University of Alabama Press.

Redeemer University College academic calendar 2000-2001/2001-2002. (2000). Ancaster, ON: Redeemer University College.

Ryken, L. (1991). Afterword. In C. Walhout \& L. Ryken (Eds.), Contemporary literary theory: A Christian appraisal. Grand Rapids, MI: Eerdmans.

Schroeder, P. R. (1993). Covering the waterfront versus taking the plunge: Curriculum revision in a liberal arts college. ADE Bulletin, 104, 33-39.

Scholes, R. (1998). The rise and fall of English. New Haven, CT: Yale University Press. 
Schramm, M., Mitchell, J. L., Stephen, D., \& Laurence, D. (2003). The undergraduate English major: Report of the 2001-2002 ADE ad hoc committee on the English major. ADE Bulletin, 134-135, 68-91.

Schwandt, T. A. (1994). Constructivist, interpretivist approaches to human inquiry. In K. Denzin \& Y. S. Lincoln (Eds.), Handbook of qualitative research (pp. 118-137). Thousand Oaks, CA: Sage.

Schwartz, L. (2003, Winter). The postmodern English major: A case study. ADE Bulletin, $133,16-24$.

Seattle Pacific University undergraduate catalog 2001-2002. (2001). Seattle, WA: Seattle Pacific University.

Shepard, A. (2003). Gumbo? On the logic of undergraduate curricula in English studies. ADE Bulletin, 133, 25-28.

Simpson College \& Graduate School 2001-2002 catalog. (2001). Redding, CA: Simpson College.

Smithson, I., \& Ruff, N. (1994). English studies/culture studies: Institutionalizing dissent. Urbana, IL: University of Illinois Press.

Spacks, P. M. (1993). Prognostications: Concluding remarks to the November MLAFIPSE English programs curriculum review conference. ADE Bulletin, 105, 3-9.

Spanos, W. V. (1989). Theory in the undergraduate English curriculum: Towards an interested pedagogy [Electronic version]. Boundary 2, 16(1/2), 41-70.

Stewart, D. C. (1989). What is an English major and what should it be? College Composition and Communication, 40(2), 188-202.

Stewart, D. C. (1990). What is an English major? Some afterthoughts. Rhetoric Review, 9, 128-131.

Strickland, R. (1994). Curriculum mortis: A manifesto for structural change [Electronic version]. College Literature, 21(1), 1-14.

Tackach, J. (1994). Rebuilding the English program at Roger Williams University. $A D E$ Bulletin, 81, 6-12.

Thomas, R. R. (2000, June 23). English majors are studying Shakespeare as well as Toni Morrison. Chronicle of Higher Education. Retrieved September 7, 2007, from http://web.ebscohost.com/ehost/detail?vid 
Tyler, R. W. (1949). Basic principles of curriculum and instruction. Chicago: University of Chicago Press

Walker, D. R. (1992) Methodological issues in curriculum research. In P. W. Jackson (Ed.), Handbook of research on curriculum. New York: Macmillan.

Waller, G. F. (1985, Fall). Working within the paradigm shift: Poststructuralism and the college curriculum. ADE Bulletin, 81, 6-12.

Waller, G. F. (1986). A powerful silence: "Theory" in the English major. ADE Bulletin, $85,31-35$.

Weber, H. (2001). Are we there yet? The long and winding road to undergraduate curricular reform. Profession 2001, 142-148.

Westmont College catalog 2002-2003. Retrieved May 31, 2003, from http://www.westmont.edu/_academics/pages/registrar/catalog/academic.

White, R. S. (2001). Shakespeare criticism, 1600-1900. In M. DeGrazia \& S. Wells (Eds.), The Cambridge companion to Shakespeare (pp. 279-295). Cambridge: Cambridge University Press.

Wilcox, T. W. (1970). A comprehensive survey of undergraduate programs in English in the United States., Washington, DC: U. S. Department of Health, Education, and Welfare.

Wilcox, T. W. (1973). The anatomy of literature. San Francisco: Jossey-Bass.

Yood, J. (2003). Writing the discipline: A generic history of English studies. College English, 65(5), 526-540. 
Curriculum Vitae for Maralee S. Crandon

Associate Professor of English at Bethel College, Indiana

Education: Ph.D. Candidate at Andrews University (Present)

Berrien Springs, Michigan

Dissertation Title: An Initial Exploration of the Undergraduate English

Major Curricula Issued by the 2000-2001 Council for Christian Colleges and Universities

Expected Date of Completion: December 2007

M.A. in English Literature (1986)

University of Notre Dame du Lac (Indiana)

M.A. in Communication, cum laude (1971)

Wheaton College Graduate School (Illinois)

B.A. in History (1969)

Houghton College (New York)

Additional Studies:

Syracuse University (New York) (1973-77)

University of Kent, Canterbury (UK) (Summer 1981)

Certification: New York State Teacher Certification (Permanent)

Grades 7 - 12 Social Studies (Issued 1969)

Grades 7 - 12 English (Issued 1976)

College Associate Professor of English and Communication (1996-Present)

Teaching: Assistant Professor of Communication (1977-1996)

Chairperson of the Language and Literature Division (1992-99)

Bethel College, Mishawaka, Indiana

Secondary Orange Park High School (FL) 1971-1973 English

Teaching: $\quad$ Faith Heritage School (NY) 1974-1977 